بسم الله الرممن الرحيم

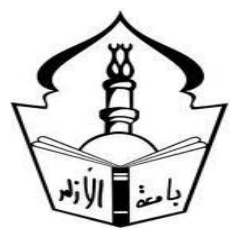

$$
\text { جامعة الأز هر الثر - فرع أسيوط اللغيفة العربية }
$$

\title{
تشرد الأهالي في مصر بسبب الغارات الجوية أثناء الحرب العالمية الثانية
}

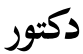 \\ أشرف محمد حسن \\ المدرس بقسم التاريخ الحديث بكلية اللغة العربية بأسيوط \\ جامعة الأزهر \\ $6 r+10-81 \leqslant \mu t$
}


$-7$. 


\section{بسم الاله الرحمن الرحيم

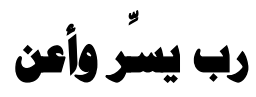

مدفل :

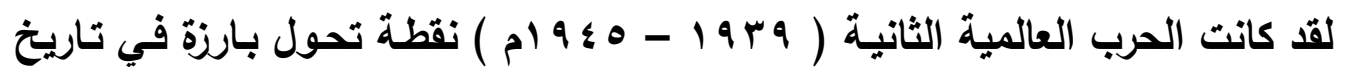
مصر المعاصر ، فموقِع البلاد الجغرافي جعل منها مركزاً للحلفاء ، كمـا شـدَّ إليها انتبـاه

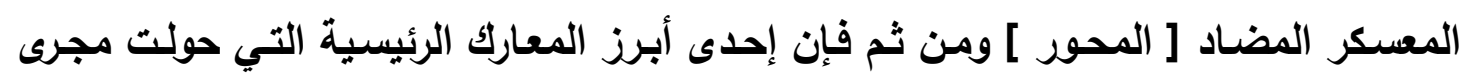

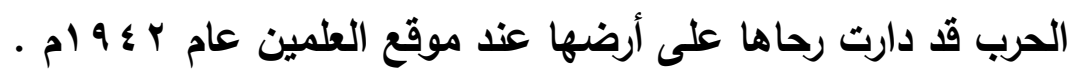

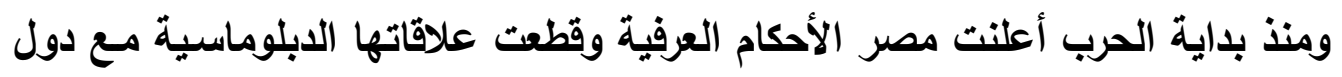

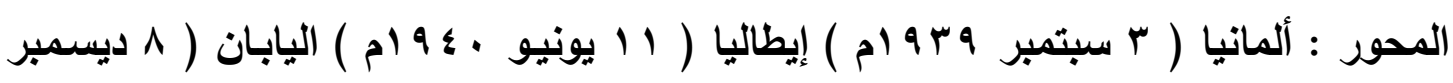

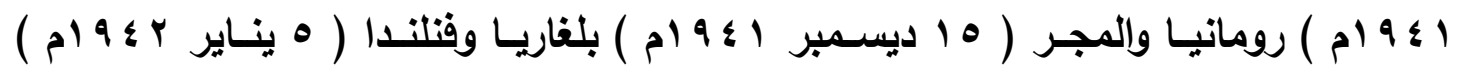

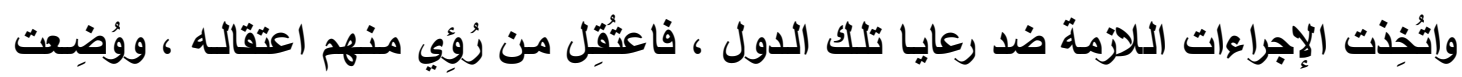

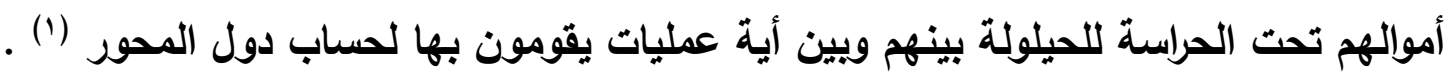

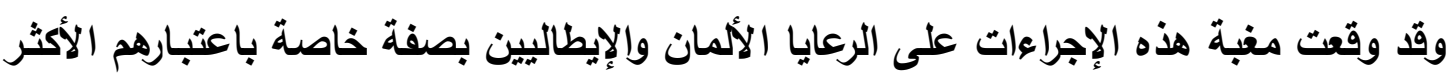

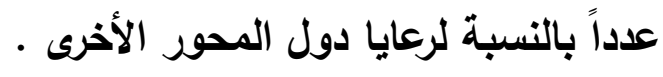
وهكذا أوفت الحكومة المصرية بالتزاماتها كاملة تجاه الحليفة بريطانيا طبقاً لمعاهدة

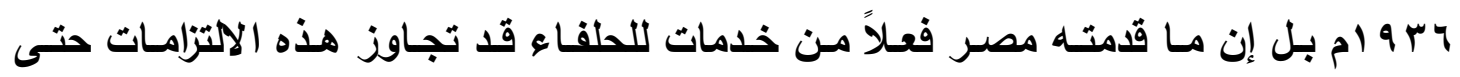

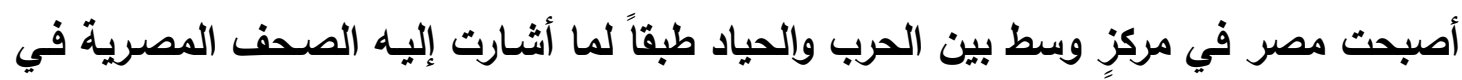

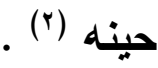
ورغم أن مصر لم تعلن الحرب رسمياً على ألمانيا إلا في أوائل سنة ه ؛ 9 ام ، ورغم

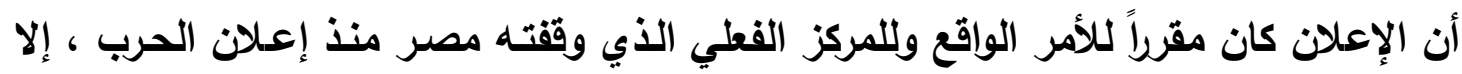

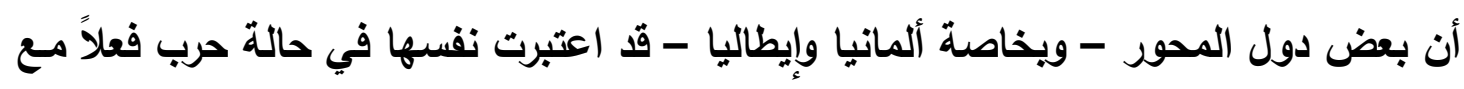

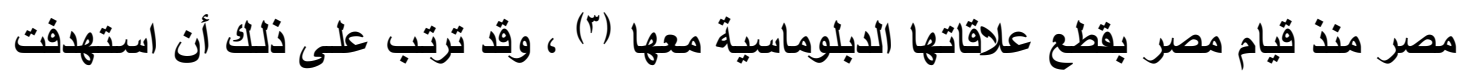

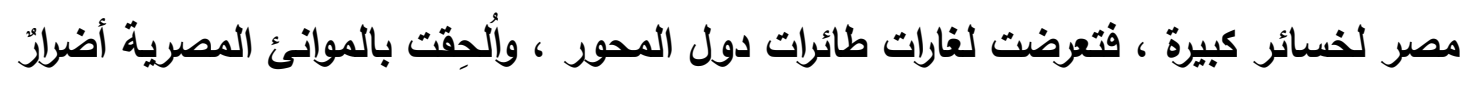

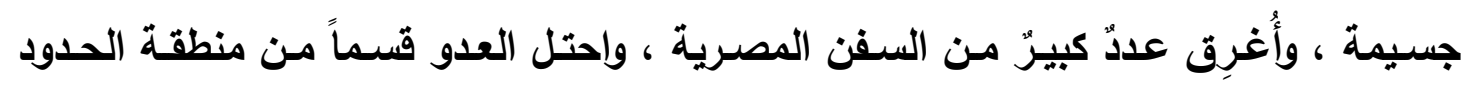

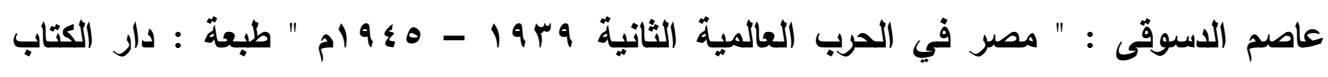

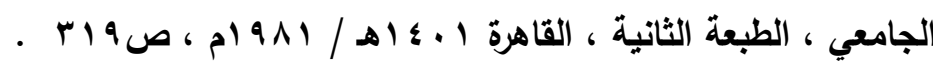

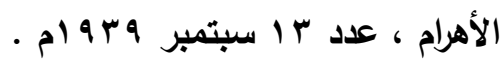

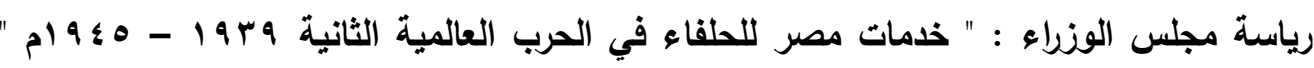

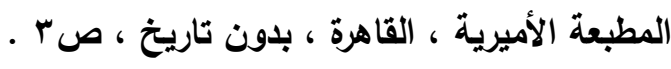


الغربية ، وظلت مسرحاً للقتال خلا ثلاث سنوات متتالية ، وأخليت مناطق كثيرة من سكانها ،

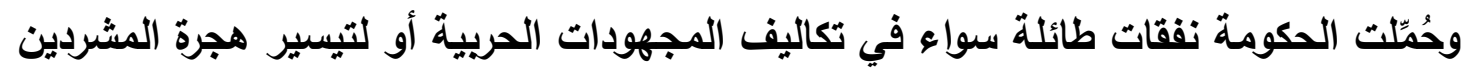

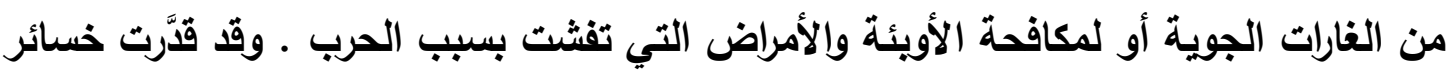

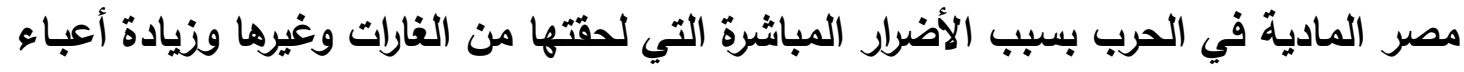

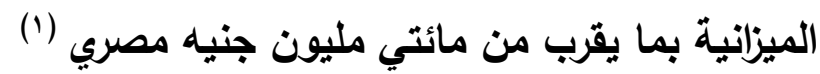

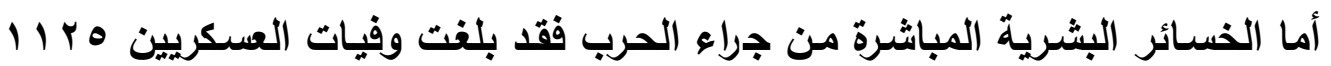

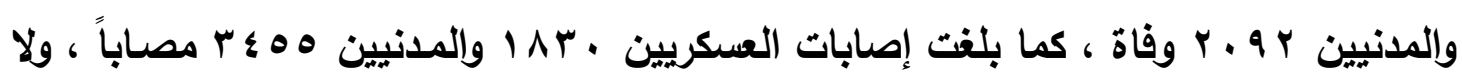

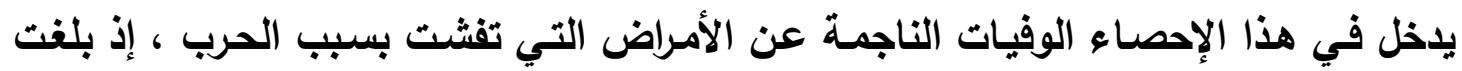

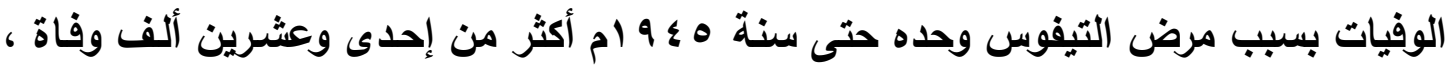

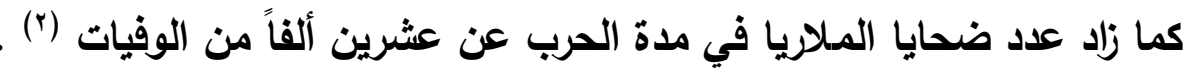
وقد استهدفت مصر أثناء الحرب بما يزيد عن مائة وثمانٍ وثلاثين غارة ، كان نصيب

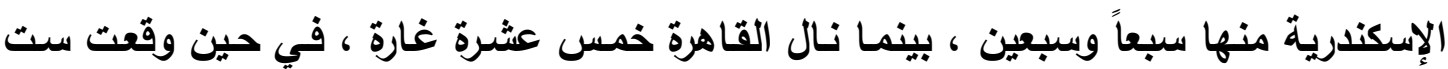
وأريعون غارة على منطقة القناة (־) ـ وقد صحب هذه هذه الغارات - كما سبقها وتلاهها - أكبر موجة للهجرة الجماعية تثهـها مصر في تاريخها الحديث ، وترتب على ذلتك تثرد عدداد كبيرٍ

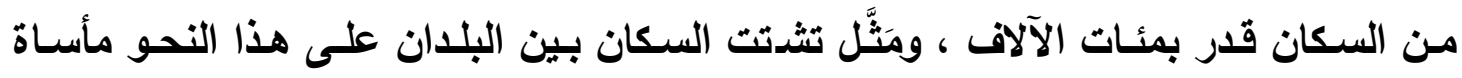
اجتماعية واقتصادية عانى المصريون منها ومن آثارها السلبية لسنوات طويلة .

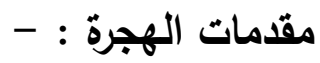
لقد كـان الاعتقـاد السـائد للدى الـرأي العـام في مصر أن البلاد بمنـأى عن الغـارات

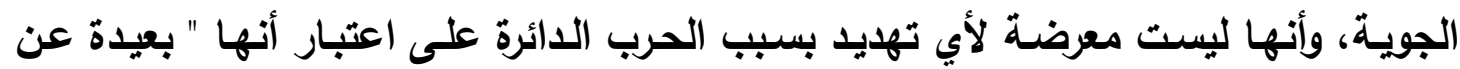

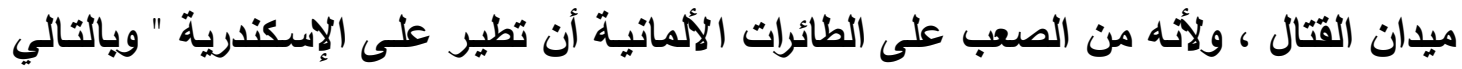

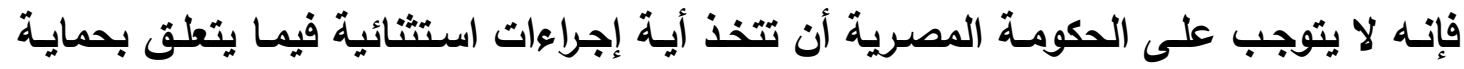
المواطنين من غارات جويـة يُستبَعد وقوعها في المستقبل القريب ، وأن أيسة إجراءات تتخذهاتها

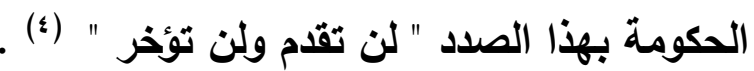
ورغم أن هذا الافتراض قد ثبت خطؤه فيما بعد إلا أن الحكومـة المصرية لم تستسلم

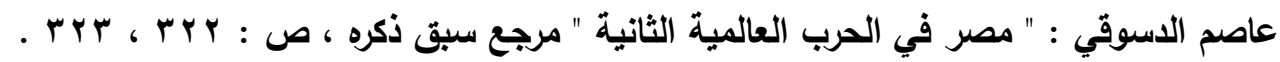

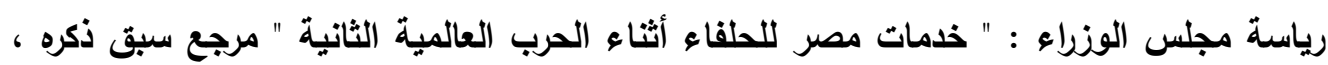

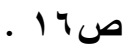

محمد جمال الدين المدي ، يونان لبيب رزق ، عبد العظيم رمضان : " مصر والحرب العالمية

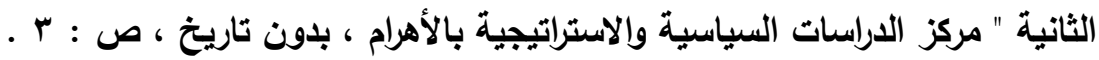

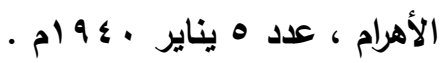


لهذه الافتراضات المطمئنة ، فوضعت - مبكراً - مشروعاً لترحيل الأهالي من المدن المزلحمة

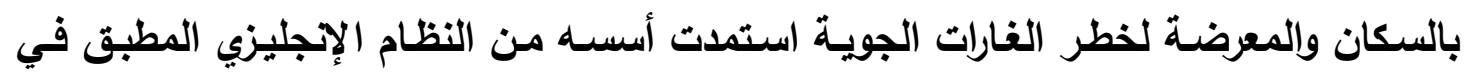

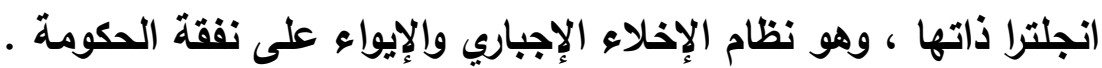

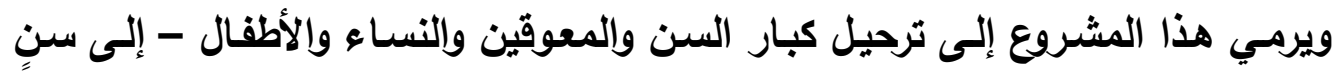
معينة - عن مناطق الخطر إجبارياً ، على أن يتكفل القادرون منهم بنفقات معيثتهم سواءً

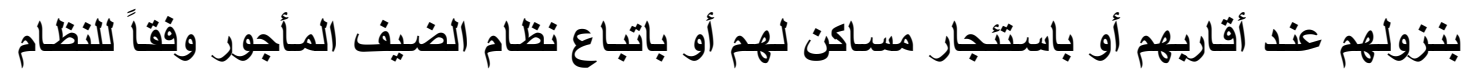

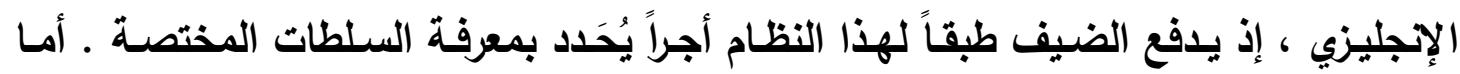

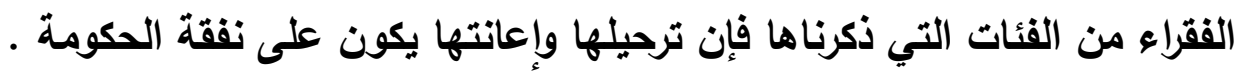

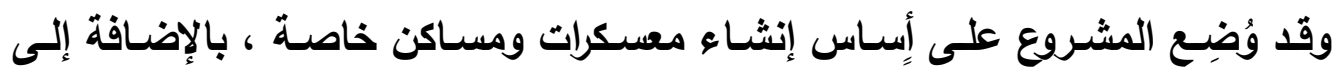

الاستعانة بالمباني المملوكة للحكومة وتفاتيش الأملاك والعزب الإيواء المرحّلين ( ) .

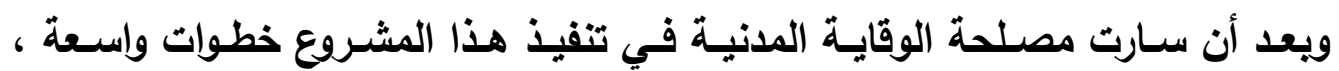

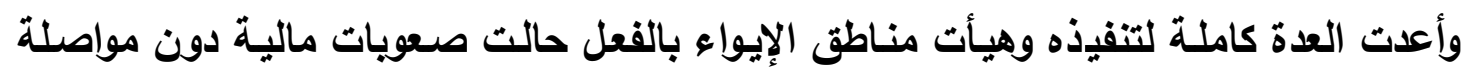

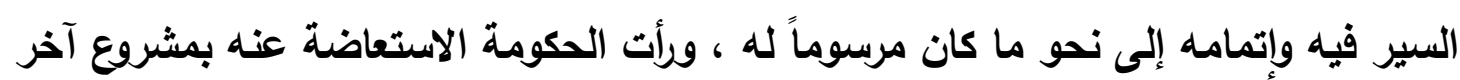

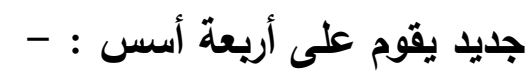

الأول : إبعاد المشبوهين والخطرين على الأمن وتدبير أماكن لإيوائهم ولعملهم بواسطة

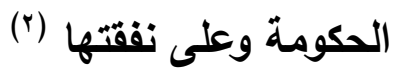

الثاني : نصح الأهالي القادرين على إيجاد مساكن بديلة لهم بترحيل أطفالهم ونسائهم وشيوخهم من الآن .

الثالث : إذا أظهر غير القادرين على العمل من النساء والأطفال الرغبة في الرحيل

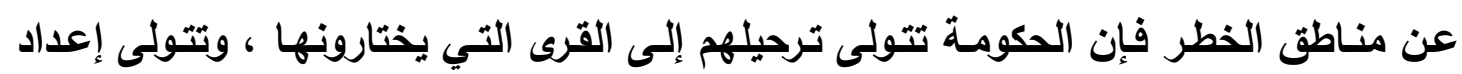

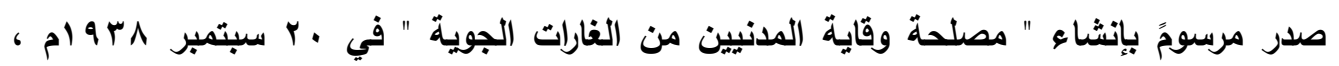

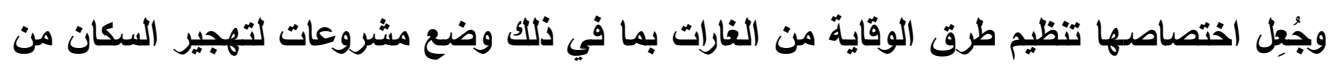
مناطق الخطر . انظر : مجلس الوزاءء ، الأمانة العامة : " تاريخ وأعمال الوزارات المصرية بمناسبة العيد المئوي

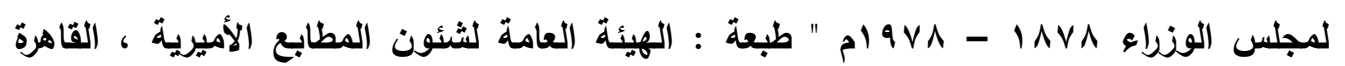

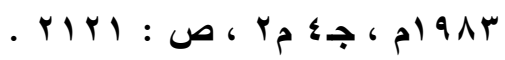
يلاحظ أن إبعاد هؤلاء لا ياخل ضمن أعمال الوقاية بل إن ترحيلهم مقصود به المحافظة على الأمن 
الأماكن التي يقيمون فيها في التكايا والمساجد وتفاتيش وزارة الأوقاف (1) .

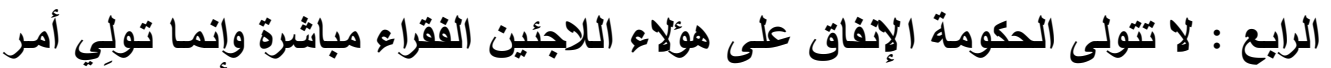

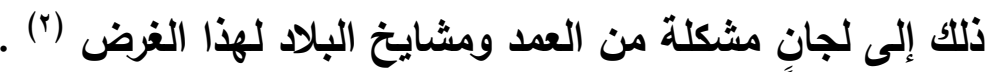
ويلاحظ على هذا المشروع الجديد خلوه من النص على الصيغة الإجبارية ، فالترحيل

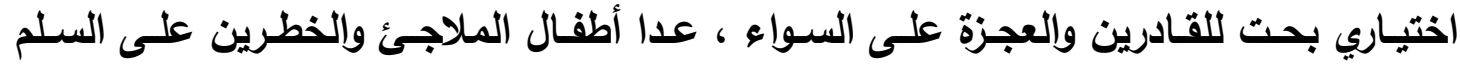

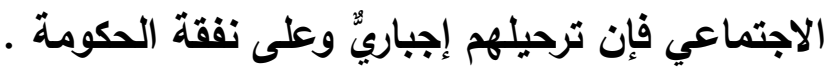
وما إن طرحت الحكومة هذا المشروع للعلن حتى بادرت الجمعيات الخيرية إلى إبداء

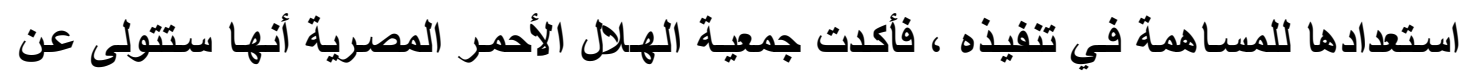
الحكومـة إنثـاء معسكرات للمهجَّرين مـن أطفـال العاصـمة الفقراء والإفـاق عليهم ، وأنها

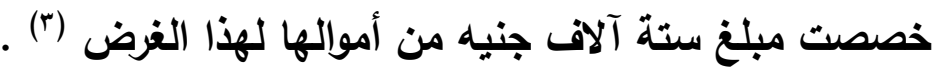
وفي إطار سعيها إلى جعل مشروع ترحيل السكان من الأمساكن المعرضـة للخطر أمراً واقعاً ، ورغبتها في تثجيع المواطنين على الرحيل الاختياري ، وحرصها على الاحتياط باتخاذ

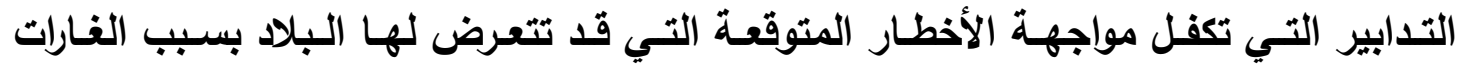

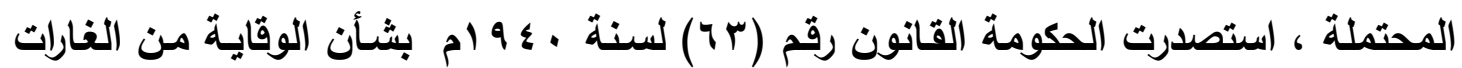

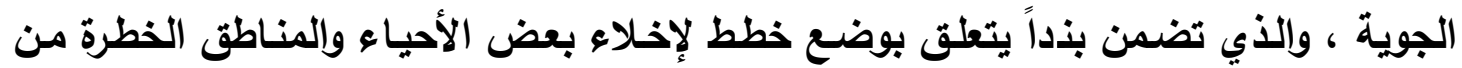

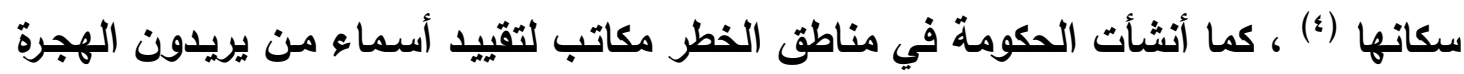

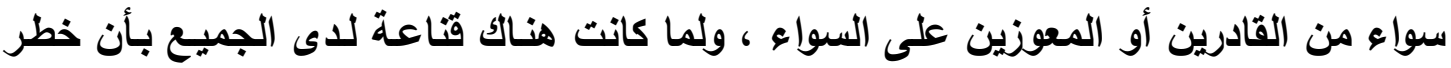

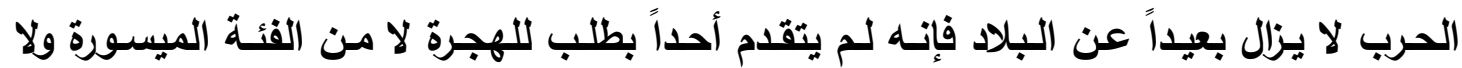

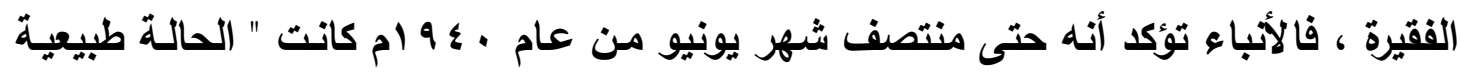

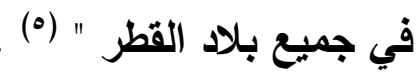
ولكن لم يكد ينتصف الثهر المذكور ، ومـا إن بـأ يُسنمَع أزيز الطائرات التابعة

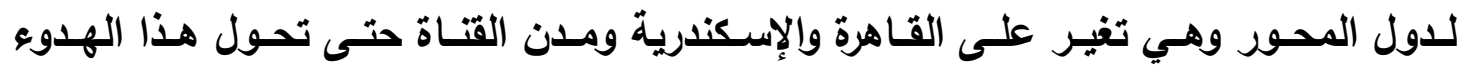
المصطنع في تلك المدن إلى حالة من الفوضى والارتباك ، ويدا واضحاً أن ما اتخذته الحكومـة

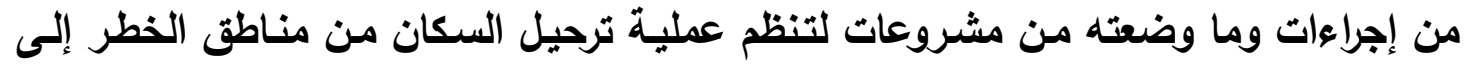

مما كان متفقاً عليه في هذه الآونة استبعاد مقارّ الددارس من الأماكن التي أعدتها الحكومة لإيواء

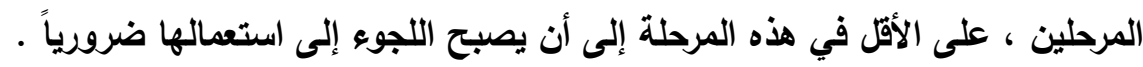

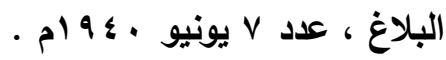

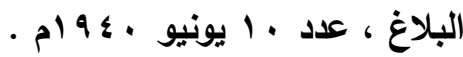

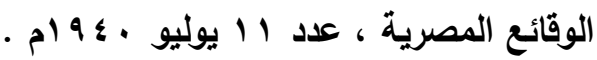

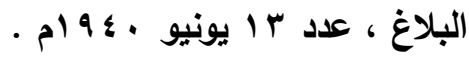


جهات أخرى أكثر أمناً - وقت الضرورة - لم تقو على الصمود أمام السيل الجارف من طالبي

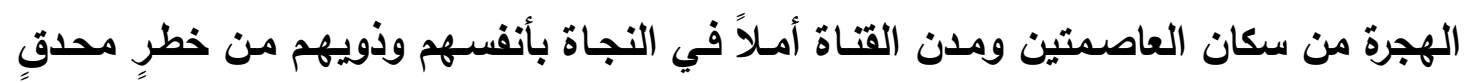

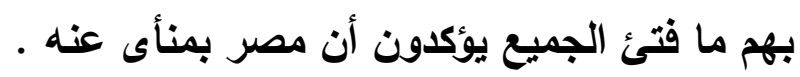

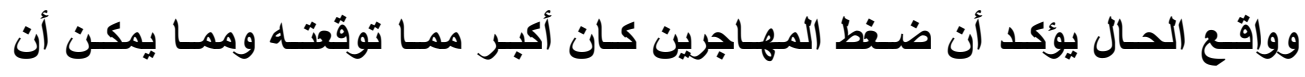

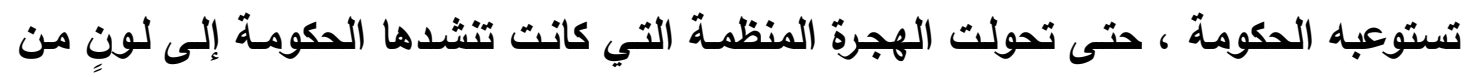

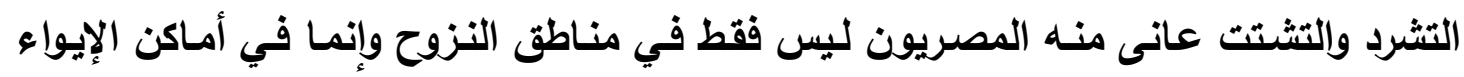

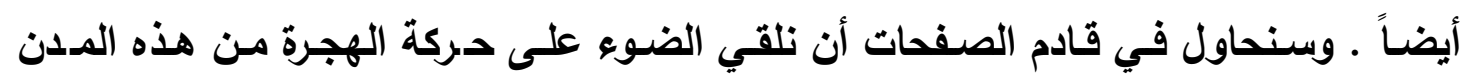

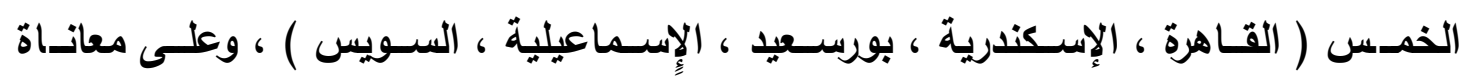

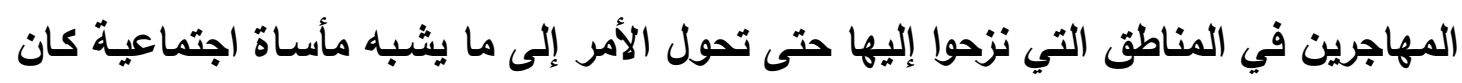

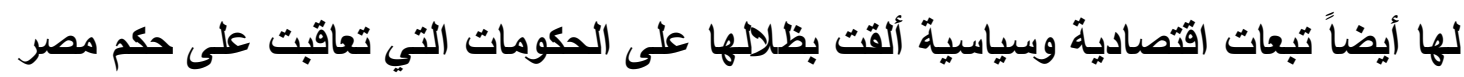
في تلك الفترة .

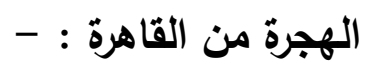

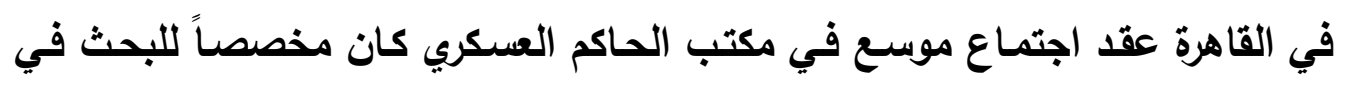

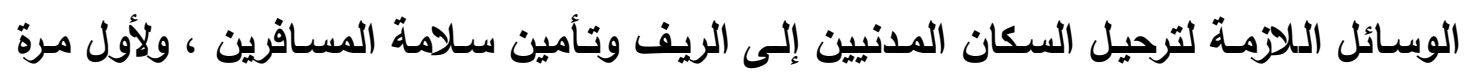

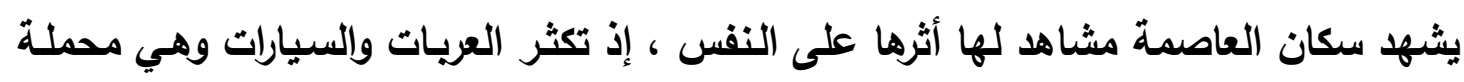

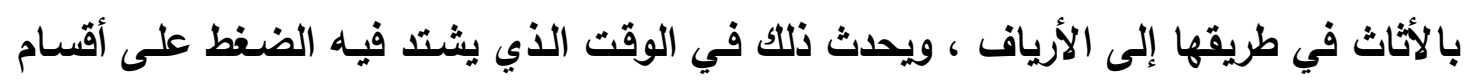

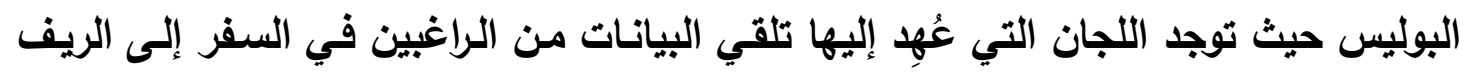

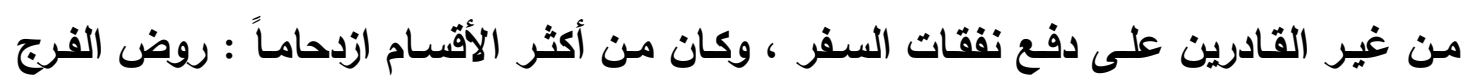

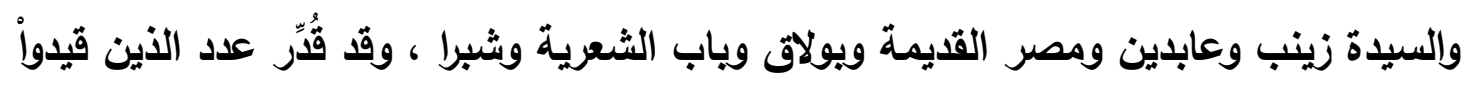

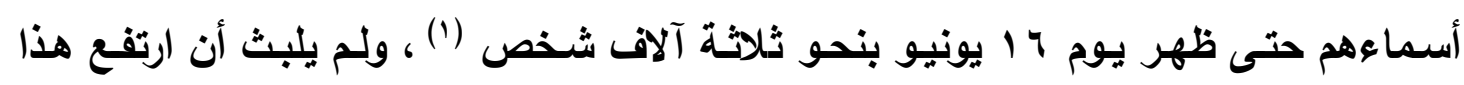

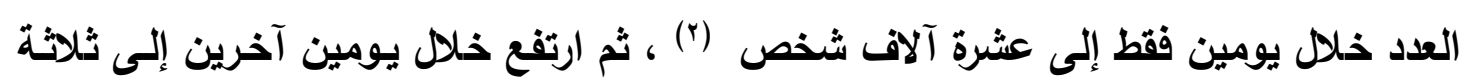

عشر ألف شخص خدم (ץ)

أمسا المسافرون الذين هجرواً العاصمة على نفقتهم الخاصـة فقد قُمِّر عددهم خـلال

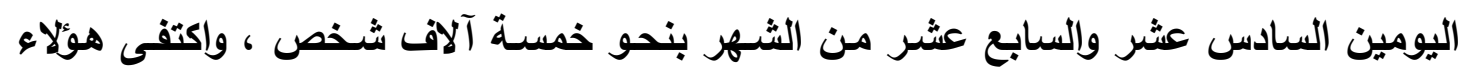

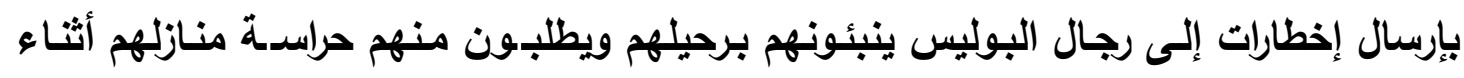

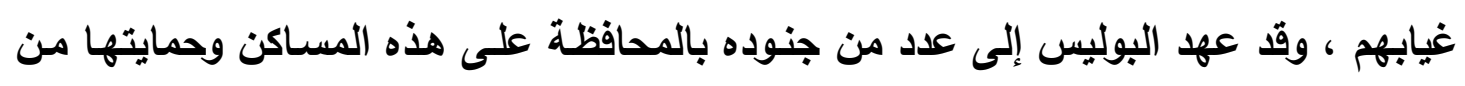

$$
\begin{aligned}
& \text { البلاغ ، عدد } 17 \text { يونيو · ؛ } 9 \text { ام . }
\end{aligned}
$$

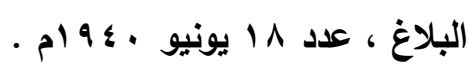

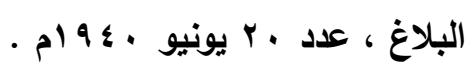


خطر السرقة (1) - مان

وفي ظل هذه الظروف كانت هناك عناية خاصة بالنساء والأطفال والثيوخ ، فظهرت

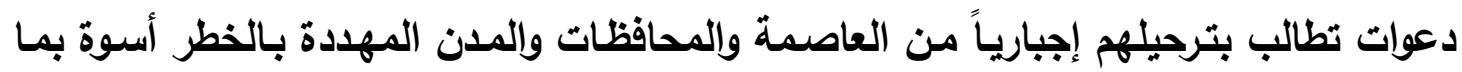

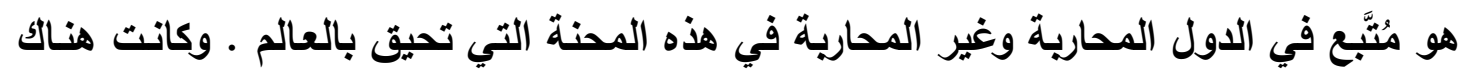

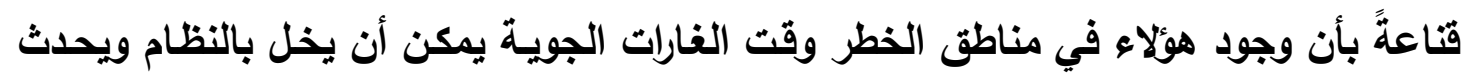

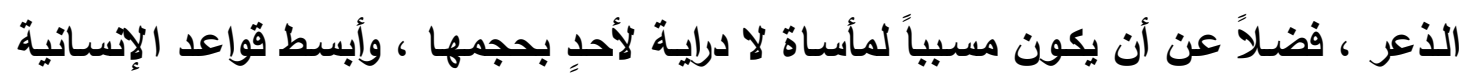

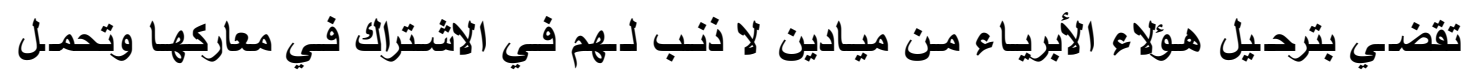
أهوالها ـ واستجابة لهذه الدعوات بدأت الحكومة بترحيل ألف طفلٍ من الائل أطفاءل ملاجئ القاهرة

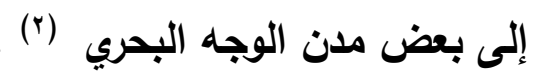

كانت حركة المهاجرين تنثط يوماً إثر يوم ، وكانت الحكومة نفسها تثجع المواطنين

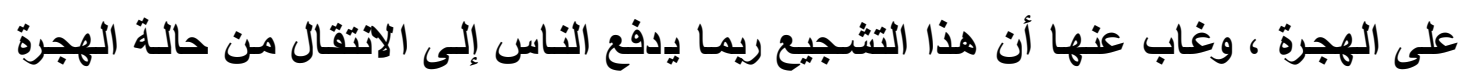

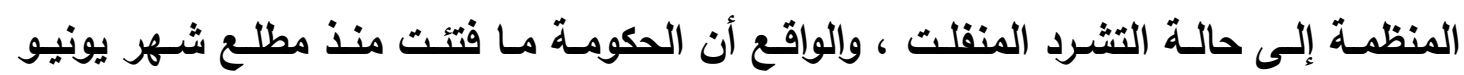

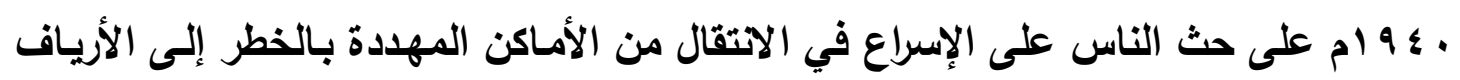

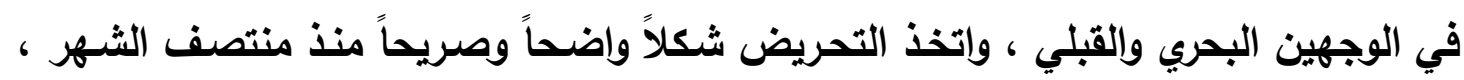

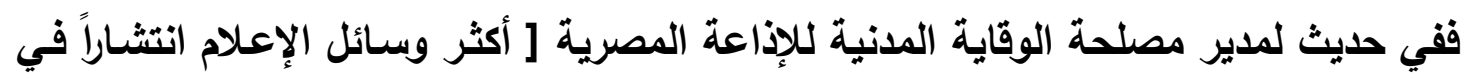

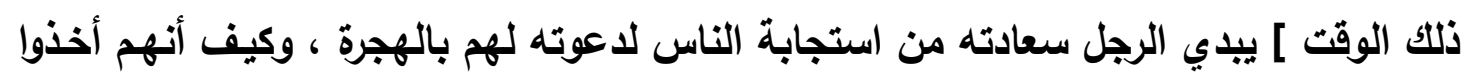

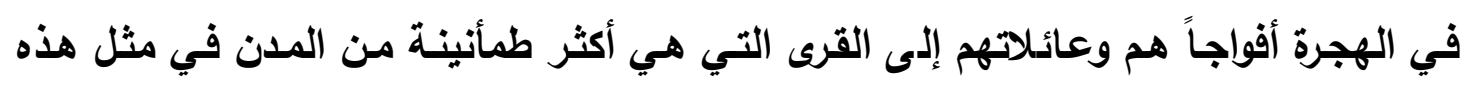

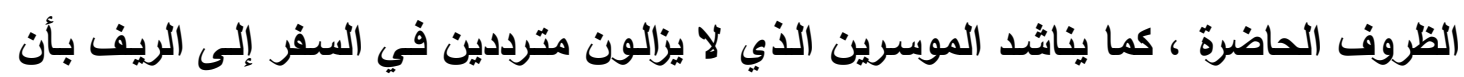

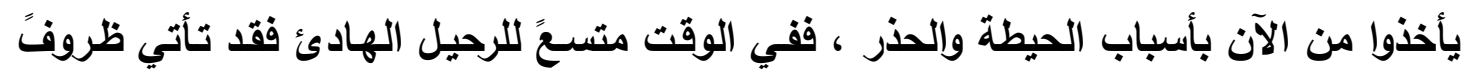

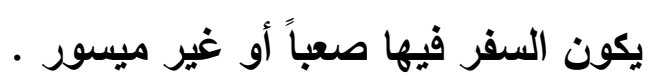

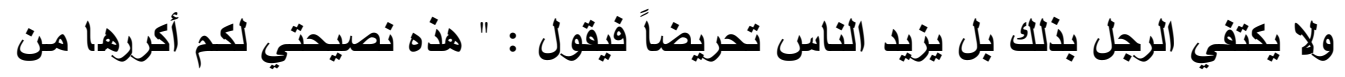

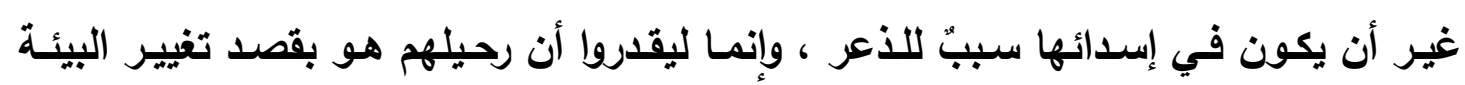

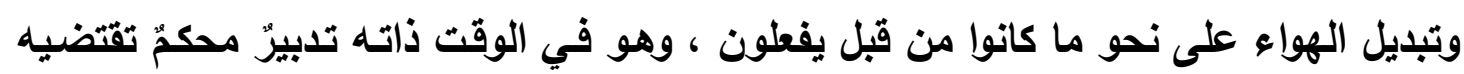

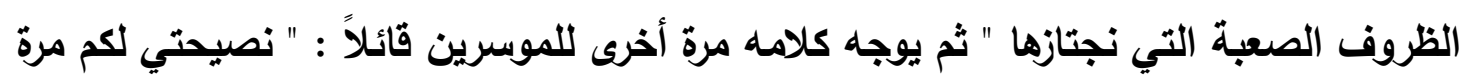

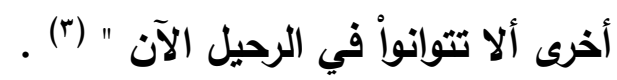
مما لا شكك فيه أن مدير مصلحة الوقاية المدنية كان صادقاً فيما قاله من أنه لا يريد

$$
\begin{aligned}
& \text { البلاغ ، عدد 11 يونيو · ؛ } 9 \text { ام . }
\end{aligned}
$$

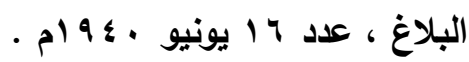

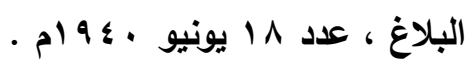


أن يسبب ذعراً للناس ، ومما لا شك فيه أيضاً أنه كان مخلصاً في نصيحته لهم بالإسراع في

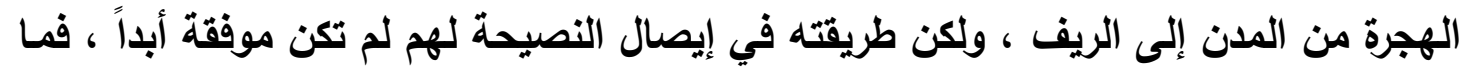

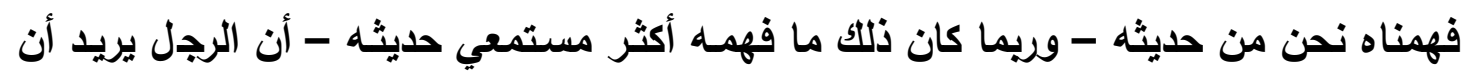

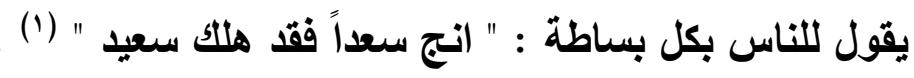

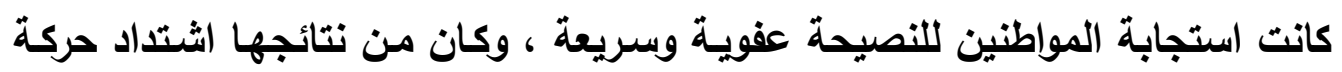

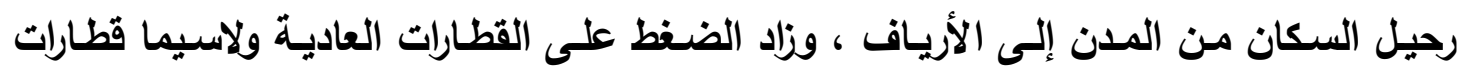

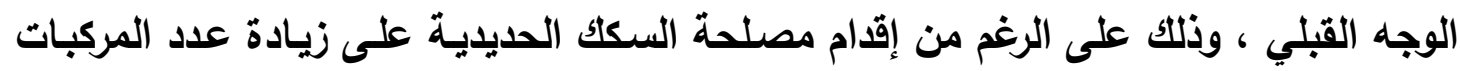

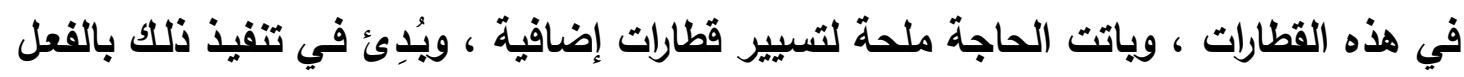

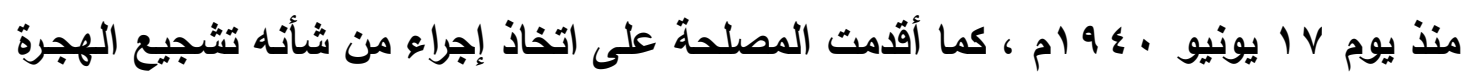

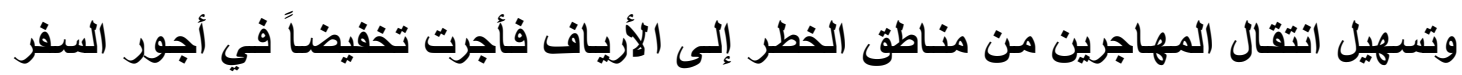

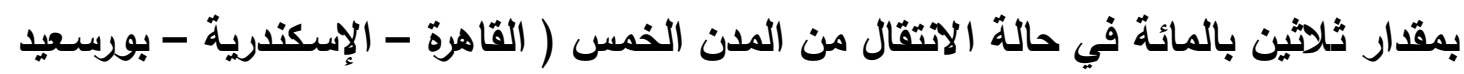

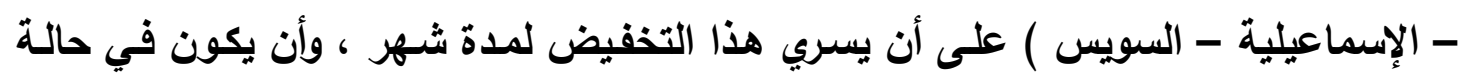

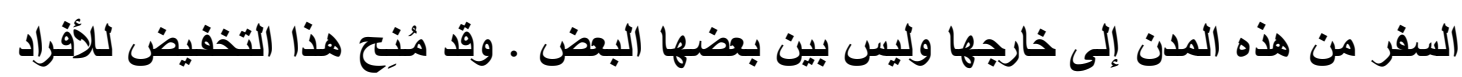

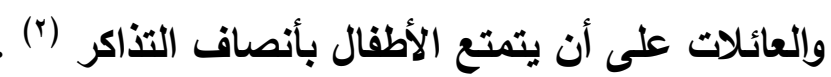

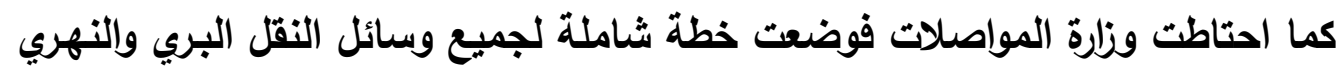

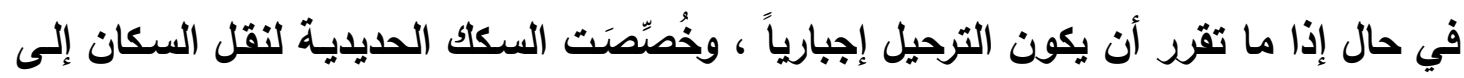

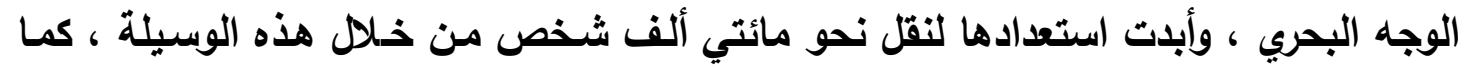

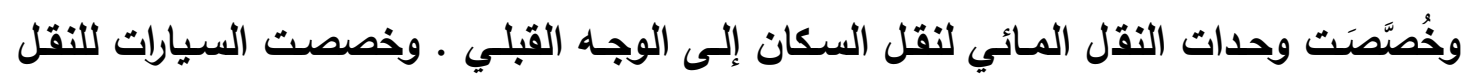

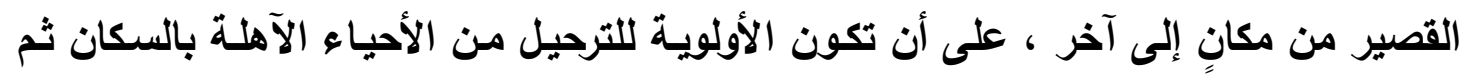

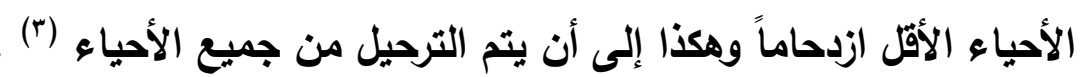

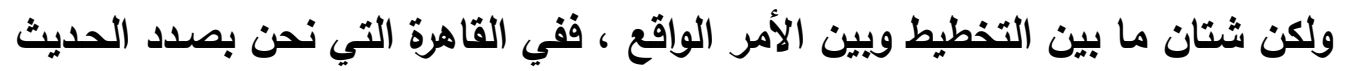
عنها تهافت الناس بثدة على مكاتب تسجيل أسماء الراغبين في الهجرة في أحيائها المختلفة

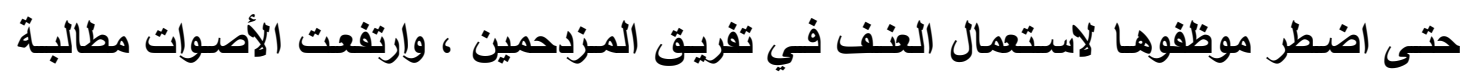

المثل يُضرَب في الاستمساك على الباقي بعد فوات الماضي ، كما يستعمل من أجل التحذير والحزم .

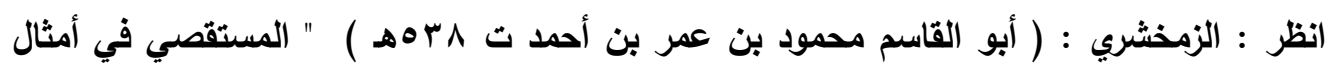

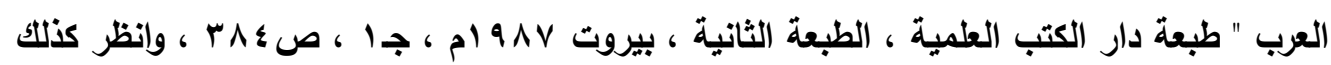

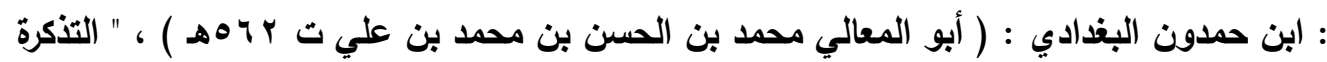

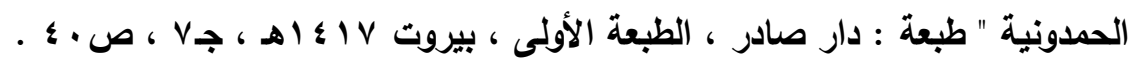

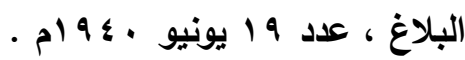

$$
\begin{aligned}
& \text { البلاغ ، نفس العدد . }
\end{aligned}
$$


بزيـادة عدد هذه المكاتب ، ومـع سريان قرار تخفيض تذاكر السفر مـن القاهرة ارتفع عدد

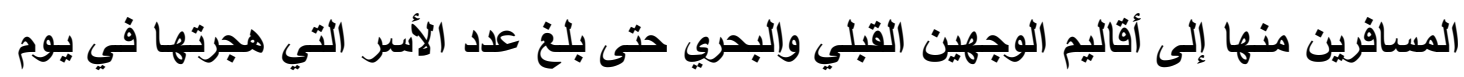

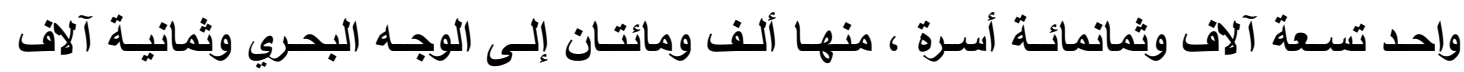
وستمائة إلى الوجه القبلي ـ واضطرت الحكومة إلى التوسع في نظام تسيير القطارات الإضافية

لمواجهة ضغط المهاجرين (1)

ورغم هذه الإجراءات الاستثنائية التي اتخذتها مصلحة السكك الحديدية إلا أن قطاراتها

أصبحت عاجزة عن مواجهة ضغط المهاجرين المتزايد ، واضطر هؤلاء إلى استخدام سيارات

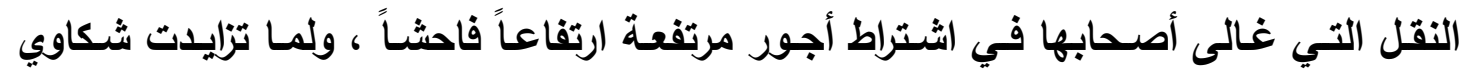
المواطنين اتخذت إدارة المرور إجراءات مشددة للإثراف على السيارات التي تتولى نقل السكان

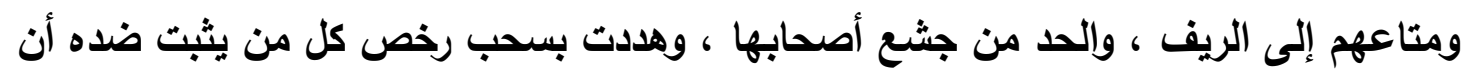

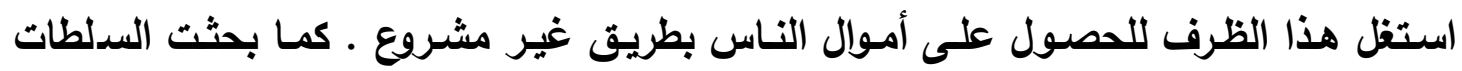

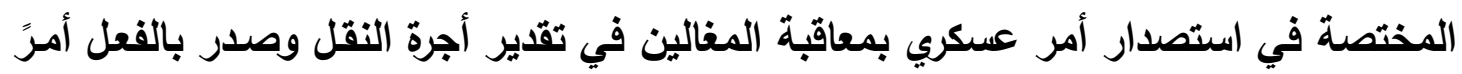

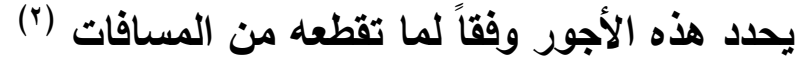

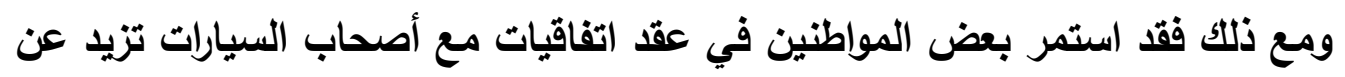

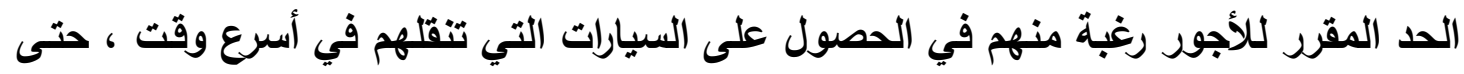

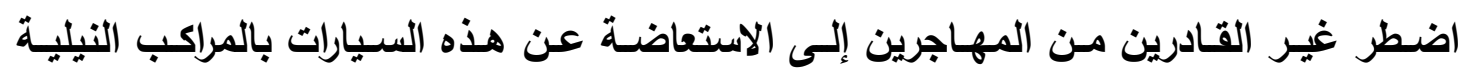

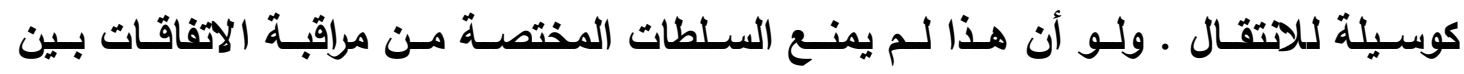

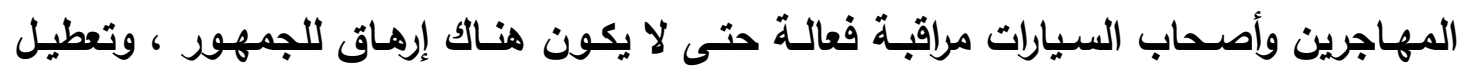

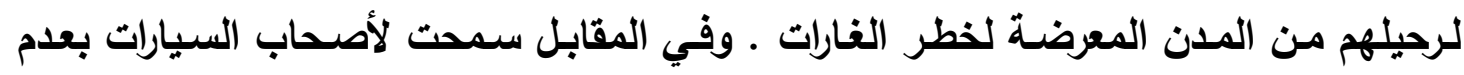

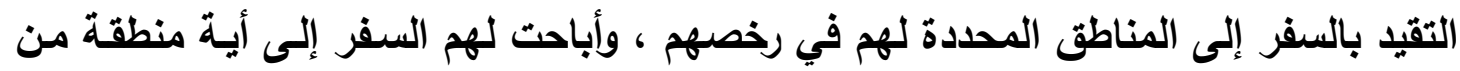

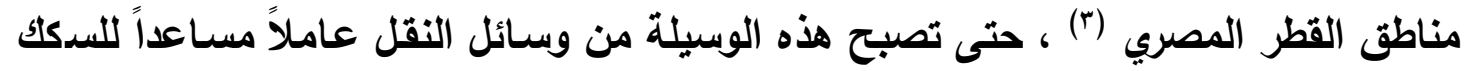

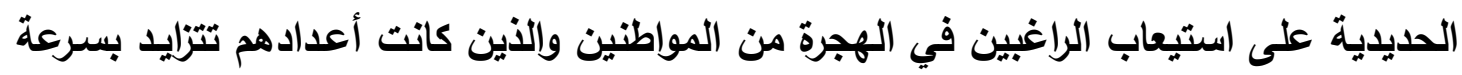

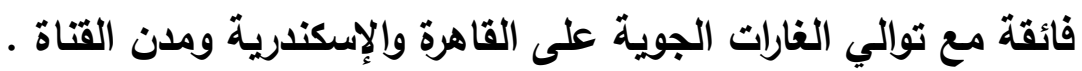

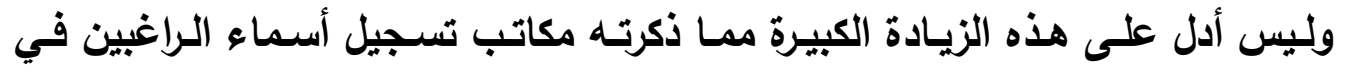

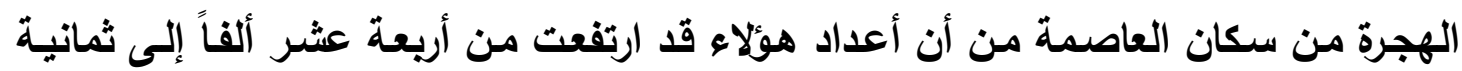
وثلاثين ألفاً ، ثم إلى ثمانية وستين ألفاً ثم إلى ثمانية وثمانين ألفاً على وجه التهاء التقريب في أيام

$$
\begin{aligned}
& \text { البلاغ ، عدد · ب يونيو · ؛ } 9 \text { ام • }
\end{aligned}
$$

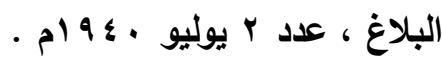

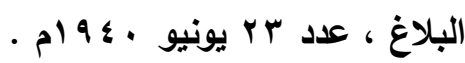




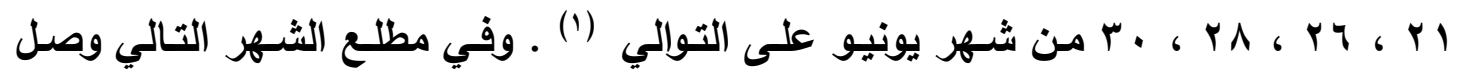

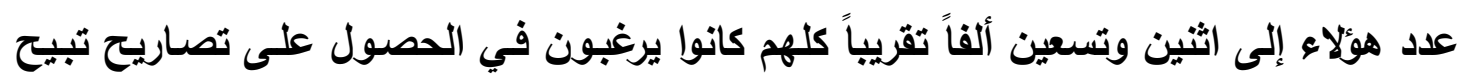

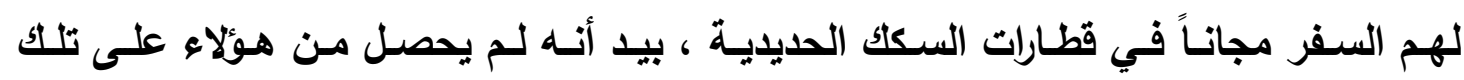

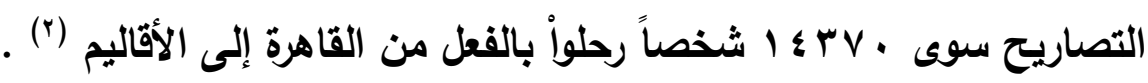

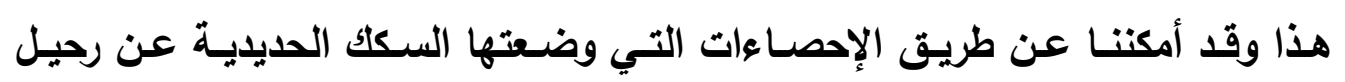

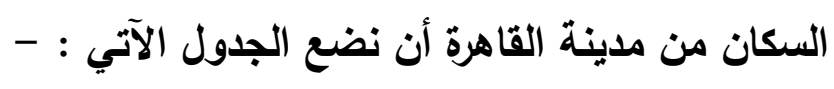

\section{(1) جدول رقال}

عدد المرتحلين من القاهرة إلى الوجهين القبلي والبحري بواسطة السكك الحديدية خلا

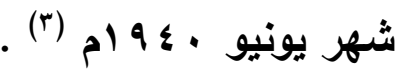

\begin{tabular}{|c|c|c|c|c|}
\hline \multirow[b]{2}{*}{ المجموع العام } & \multirow[b]{2}{*}{ المجموع } & \multicolumn{2}{|c|}{ عدد المسافرين } & \multirow[b]{2}{*}{ المـــدة } \\
\hline & & الثالثة & الثانية & \\
\hline & Dr...r & ए9701 & I. rAr & من / يونيو إلى · 1 يونيو \\
\hline & orq.v & $\varepsilon \leqslant \wedge$ ४ & $9 \cdot 1$. & من 11 إلى · ب يونيو \\
\hline & $\varepsilon \leqslant \uparrow 90$ & $r r \leq 90$ & $1.1 \ldots$ & من اب يونيو إلى ب Y يونيو \\
\hline & $\varepsilon q \mu r$ & $؟$ & $؟$ & يوم اب يونيو \\
\hline & or. 9 & $؟$ & $؟$ & "'" " "' r r " " " ) \\
\hline & TVVr & $\varphi$ & $\varphi$ & "'" "'" " " " " \\
\hline & Irr.r & 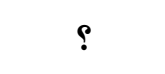 & 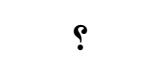 & "'" "'" $r \leq "$ " " $\}$ \\
\hline & vrq. & $\varphi$ & $\varphi$ & 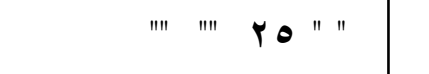 \\
\hline \multirow[t]{4}{*}{ IEAYTO } & ษレ^^ & $?$ & $\varphi$ & ) J " " " " " " " " \\
\hline & Y100 & $\varphi$ & $\varphi$ & " يونيو rV " " \\
\hline & $\Delta \wedge \leq 7$ & $؟$ & $\varphi$ & " يونيو " " " \\
\hline & 719. & $؟$ & $؟$ & " " " ج بونيو \\
\hline $179 \leq \leqslant 7$ & trte. & 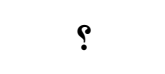 & 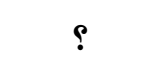 & " " " ب يونيو \\
\hline
\end{tabular}

انظر : أعداد جريدة البلاغ الصادرة في الأيام الدذكورة .

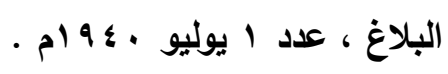

وضغنا هذا الجدول بالرجوع إلى الإحصاءات التي أوردتها جريدة " البلاغ " في عداديها الصادرين في ، بوني 
ومما هو جديرً بالذكر أن هذا الإحصاء مقصورُ على ركاب الدرجتين الثانية وإثالثة

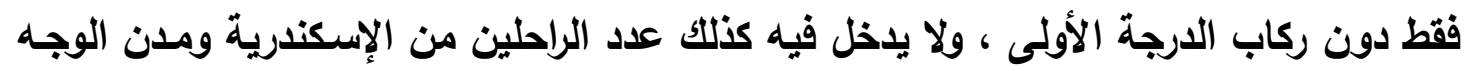

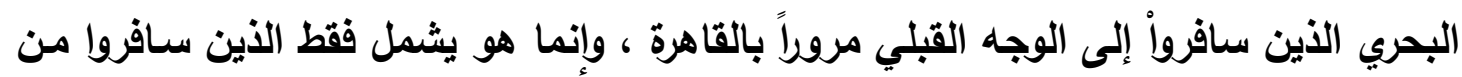

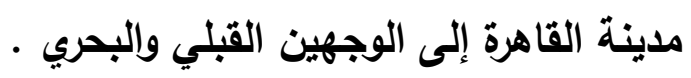
وتضطر مصلحة السـكك الحديديـة إلـى تسيير قطـارات إضـافية إلـى الوجـه القبلـي

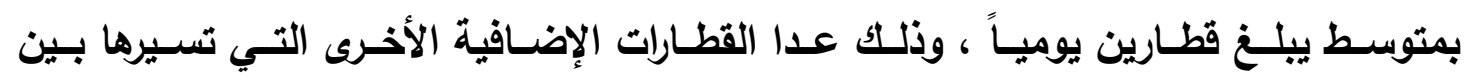

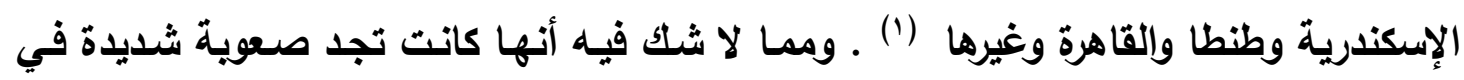

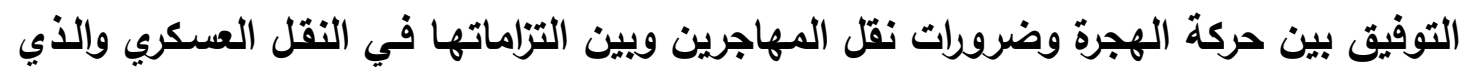

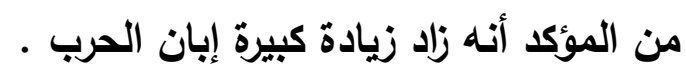

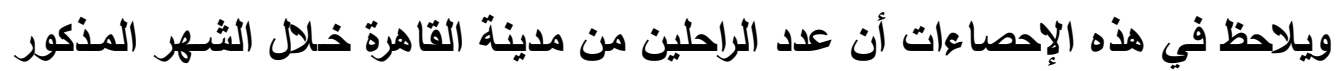

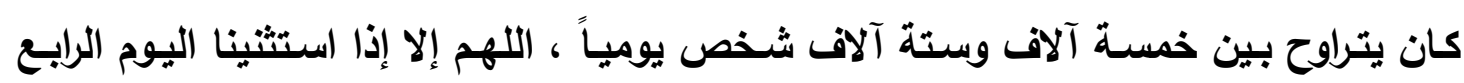

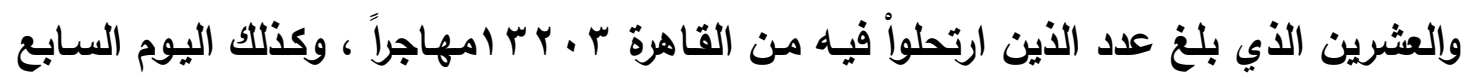

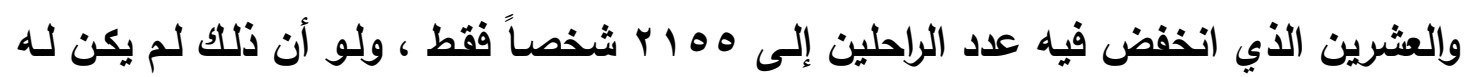

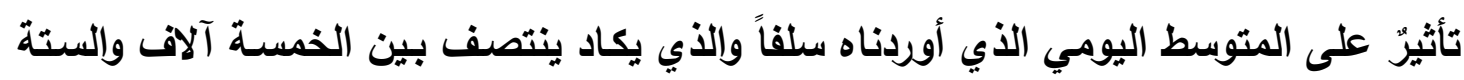

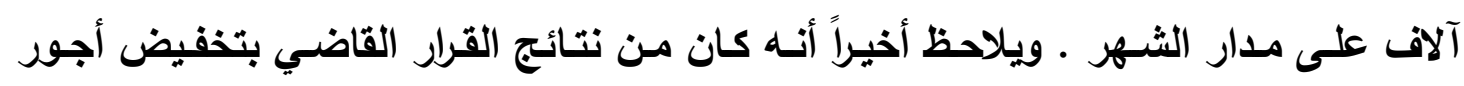

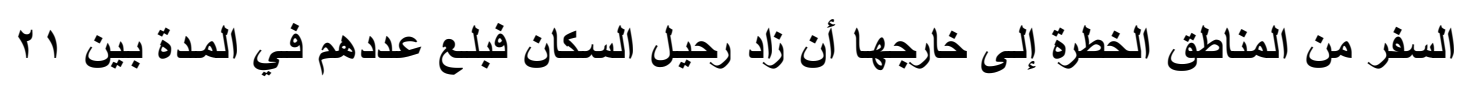

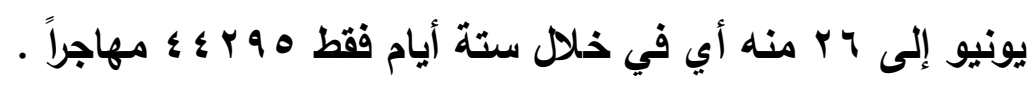

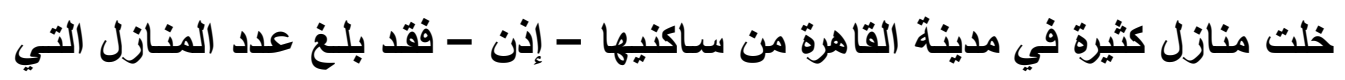

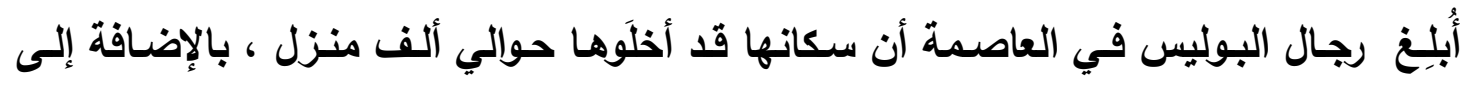

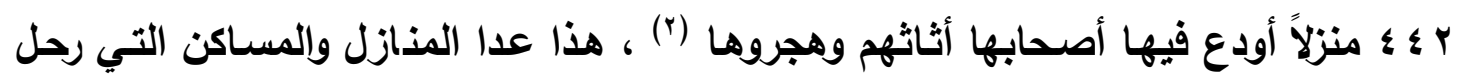
أصحابها إلى الريف دون أن يخطروا البوليس ، ووزعت محافظة العاصمة نشرة على مأموري

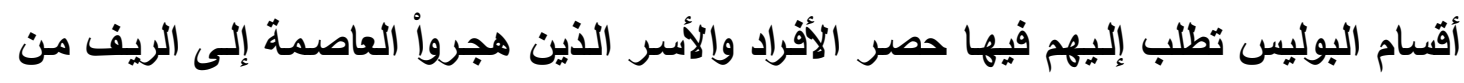

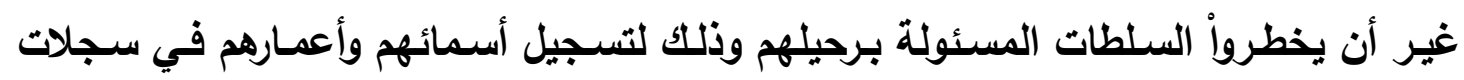

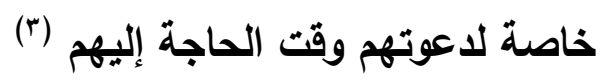
وفي النصف الأول من شهر يوليو • ؛ 9 ام استمرت حركة رحيل السكان بوتيرتها

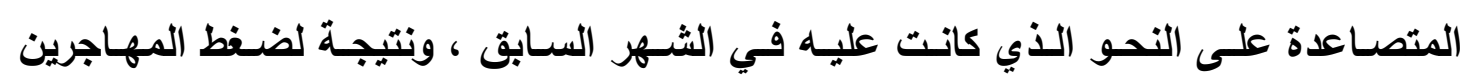

$$
\begin{aligned}
& \text { البلاغ ، عدد ب يوليو · ـ9 ام . }
\end{aligned}
$$

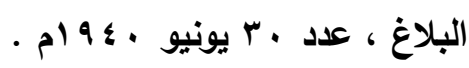

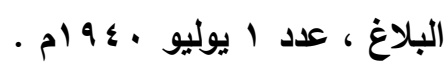


اضطرت السكك الحديدية إلى تسيير قطارات إضافية بلغ عددها ستة قطارات يومياً من القاهرة

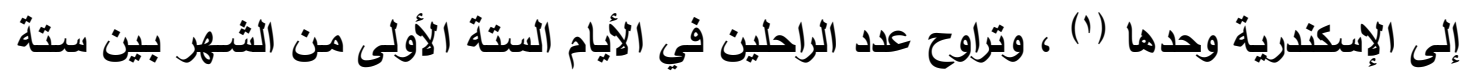

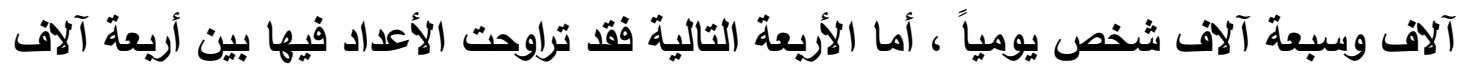

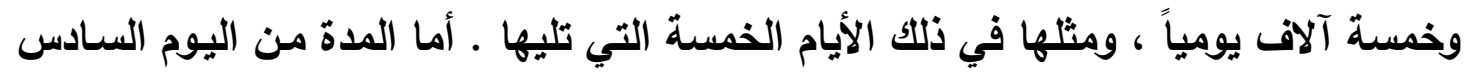

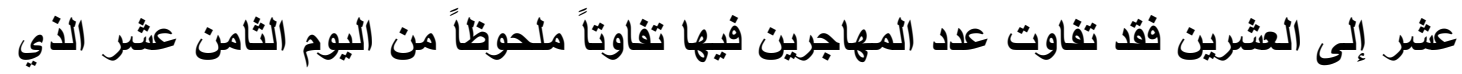

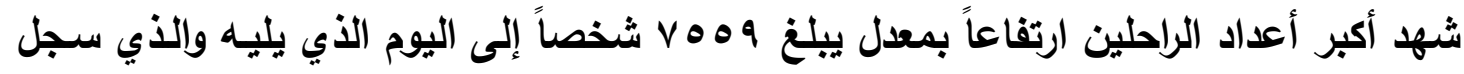

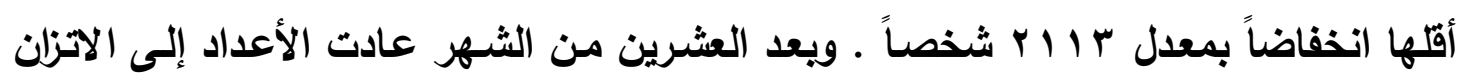

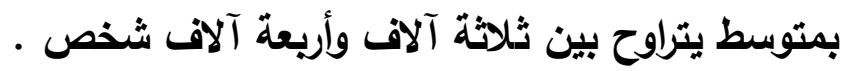

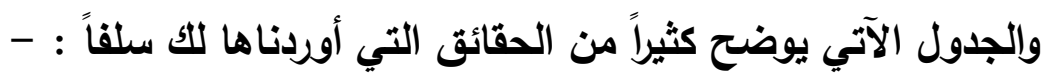

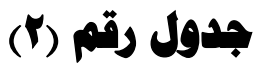

عدد الراحلين من القاهرة إلى الوجهين القبلي والبحري بواسطة السكك الحديدية خـلا

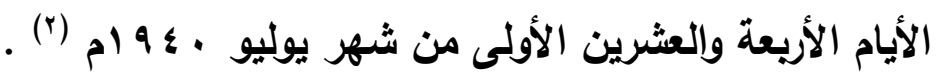

\begin{tabular}{|c|c|c|c|}
\hline المجموع العام & المجموع & عدد المسافرين & المـدة \\
\hline & & 091 . & ا يوليو · ع ام \\
\hline & & צזיזד & " " " " " " " " " \\
\hline & & 1०ᄉ & r " " " " " " " " " \\
\hline & & VIVA & ع " " " " " " " " " " \\
\hline & & $V r \leq r$ & • " " " " " " " " " " " \\
\hline & & $\vee \vee \vee \wedge$ & ד \\
\hline & \& & & \\
\hline & & $\varepsilon \leqslant 9 \vee$ & " " " " " " " " " " " \\
\hline & & $0 \times 19$ & ^ " " " " " " " " " \\
\hline & & $0 \% . \wedge$ & " " " " " " " \\
\hline
\end{tabular}

$$
\text { البلاغ ، عدد } 1 \text { يوليو · ؛ } 9 \text { ام . }
$$

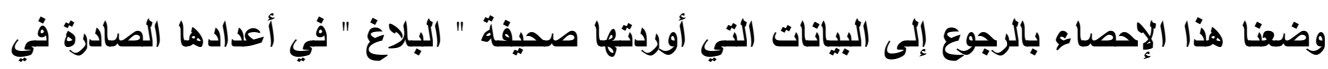

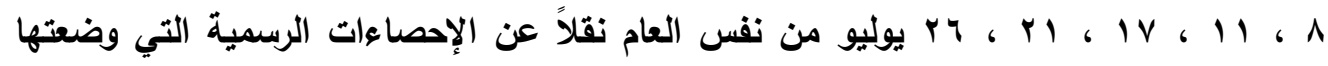

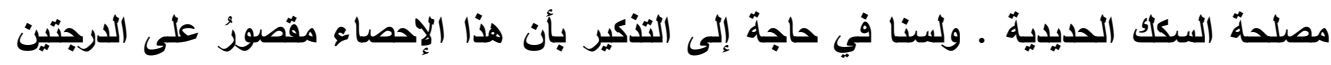

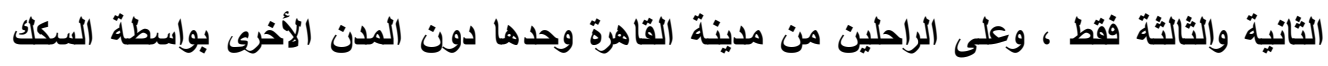




\begin{tabular}{|c|c|c|c|c|c|c|}
\hline & & $0 \curlyvee \wedge 0$ & " " & " " & " " & 1. \\
\hline \multirow[t]{6}{*}{$701 \mathrm{M}$} & 410.9 & & & & & \\
\hline & & 0.11 & " " & " " & " " & 11 \\
\hline & & $\varepsilon \wedge \mu_{0}$ & " " & " " & " " & ir \\
\hline & & $0 . \mathrm{M}$ & " " & " " & " " & ir \\
\hline & & $\varepsilon V \leqslant Y$ & " " & " " & " " & $1 \varepsilon$ \\
\hline & & OHAT & " " & " " & " " & 10 \\
\hline \multirow[t]{6}{*}{$q .1 \leq V$} & Yo..q & & & & & \\
\hline & & هrr & " " & " " & " " & 17 \\
\hline & & $\varepsilon \vee V \varepsilon$ & " " & " " & " " & IV \\
\hline & & Vooq & " " & " " & " " & 11 \\
\hline & & $r \| r$ & " " & " " & " " & 19 \\
\hline & & $\varepsilon Y \cdot 1$ & " " & " " & " " & $r$. \\
\hline \multirow[t]{5}{*}{$11 \leqslant 1 Y q$} & rrqAr & & & & & \\
\hline & & גז" & " " & " " & " " & YI \\
\hline & & $\varepsilon q Y V$ & " " & " " & " " & rr \\
\hline & & rᄉाq & " " & " " & " " & $r r$ \\
\hline & & rq. & " " & " " & " " & $r \varepsilon$ \\
\hline $1 \% .19 \%$ & 17.78 & & & & & \\
\hline
\end{tabular}

يعني ذلك أن ما نقلته السكك الحديدية من مهاجري القاهرة إلى الأرياف خلاله أريعة

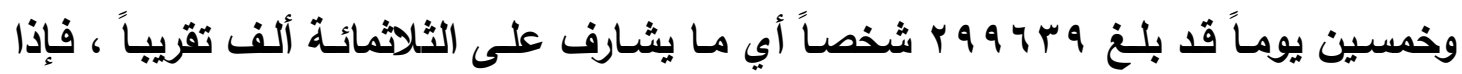

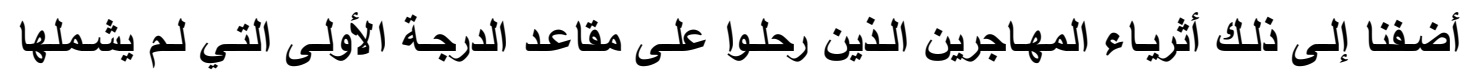

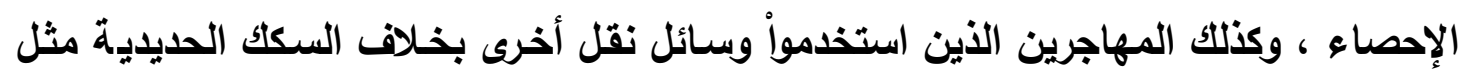

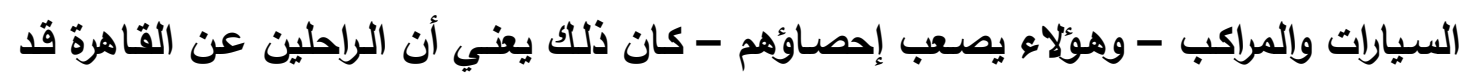

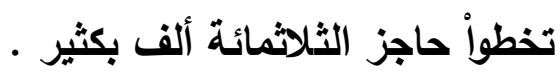
ولكن تطفو على السطح هنا إثكالية مهمـة وهي أنه ليس كل من استقل قطارات

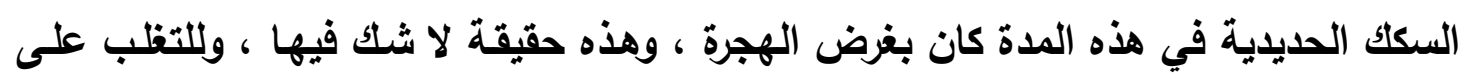

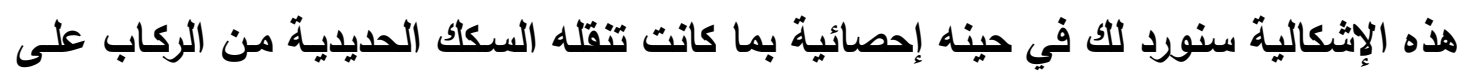

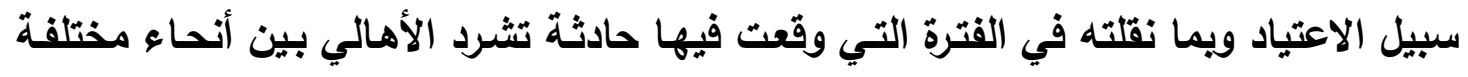


من القطر المصري ، ومما لا جدال فيه أن الفارق حينئذٍ بين الرقمين - وهو كبير - مرده إلى هذه الهجرة الاستثنائية .

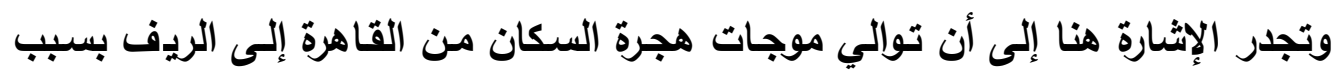

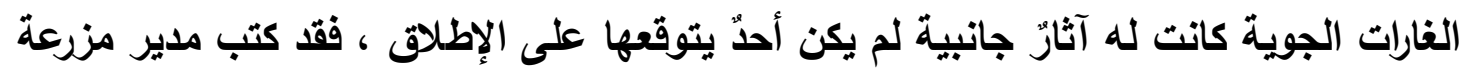

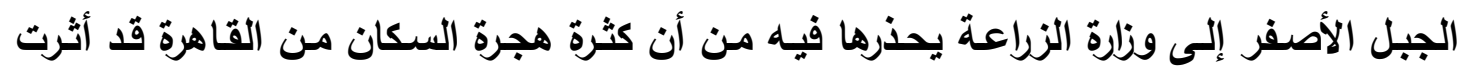

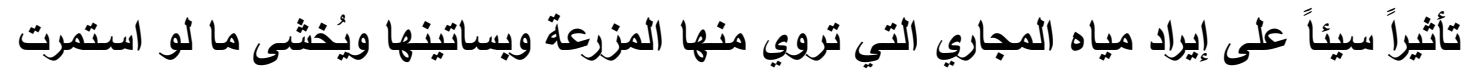

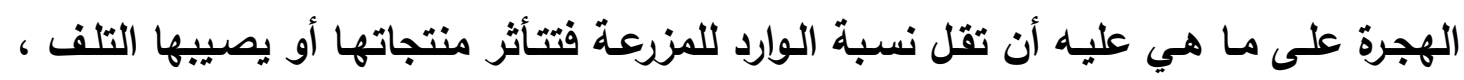

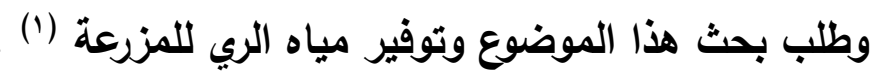

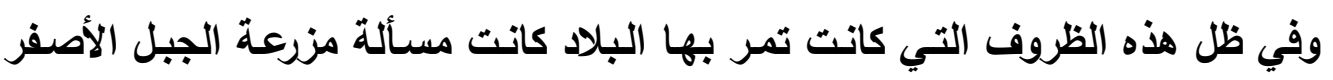
وتوفير موارد المياه لها أبعد ما تكون عن اهتمامات الحكومة التي كانت تنتظرها مهام جسام

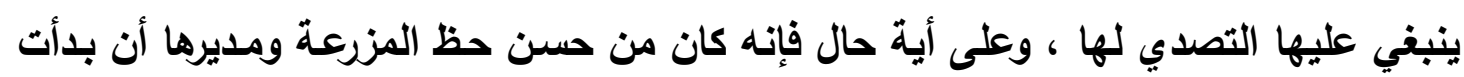

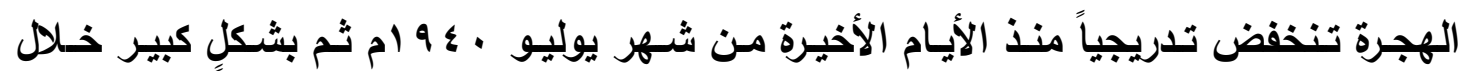

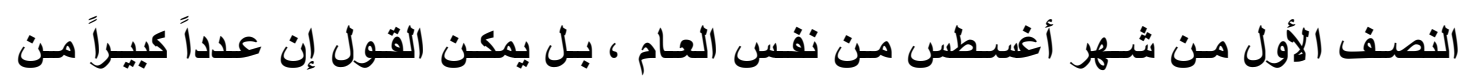
الأثخاص الذين هجرواً العاصمة قد عادواً إليها مرة أخرى .

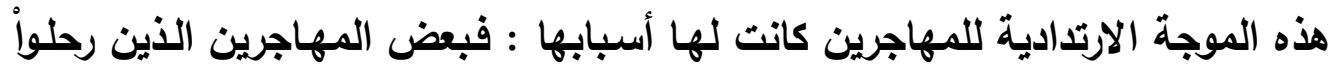

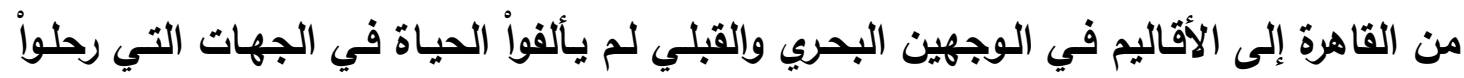

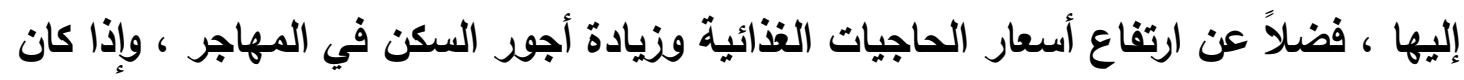

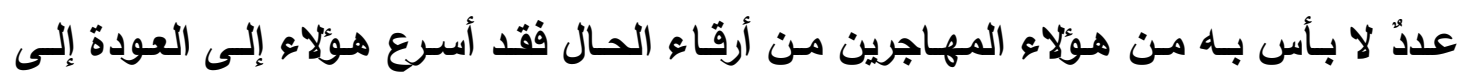

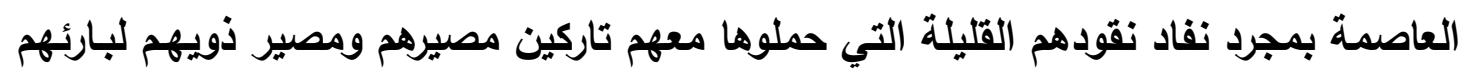

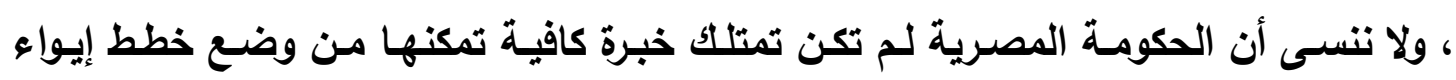

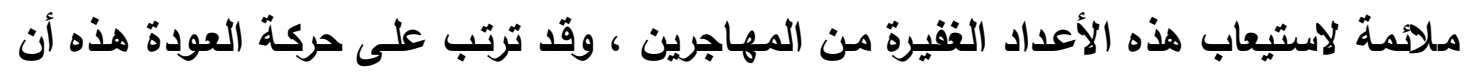

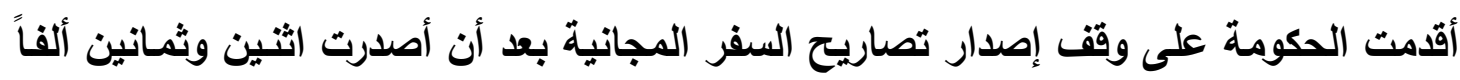

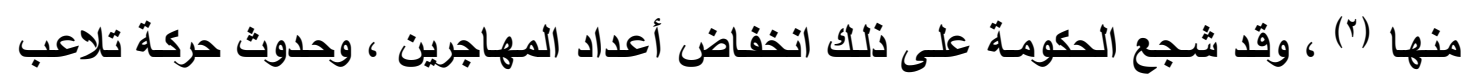

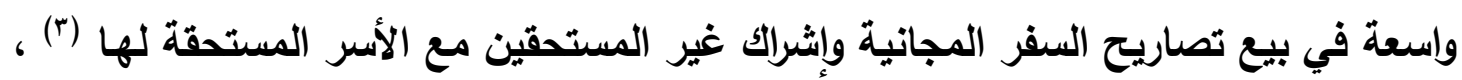

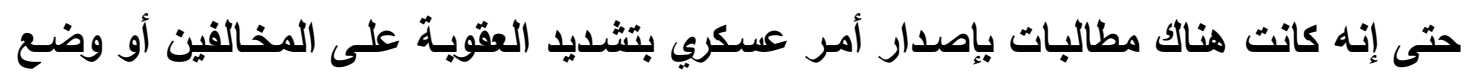

$$
\begin{aligned}
& \text { البلاغ ، عدد } 1 \text { يوليو · ـ9 ام . }
\end{aligned}
$$

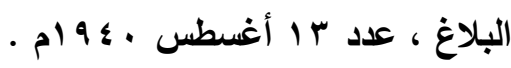

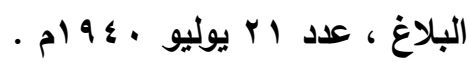


صورٍ شخصية على استمارات السفر منعاً للتحايل (') .

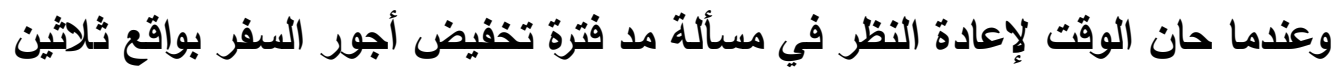
بالمائة للراحلين من المدن الخمس الخطرة ( القاهرة ، الإسكندرية ، بور سعيد ، الإسماعيلية،

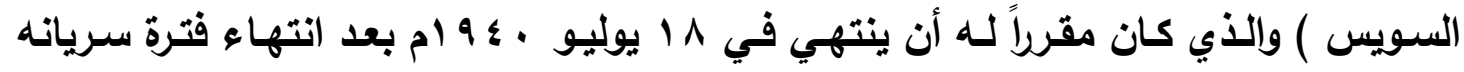

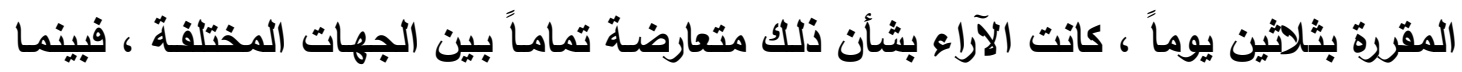

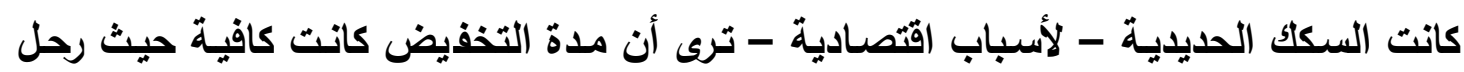

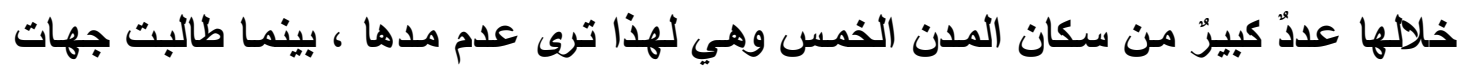

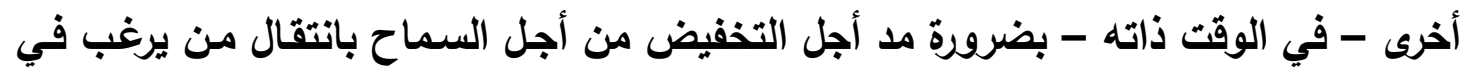

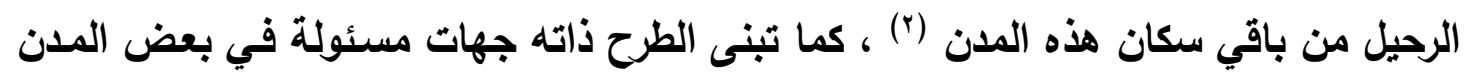
التي شهـت تكدساً بالمهاجرين من أجل تثجيع هؤلاء على العودة مرة أخرى إلى مواطنهم

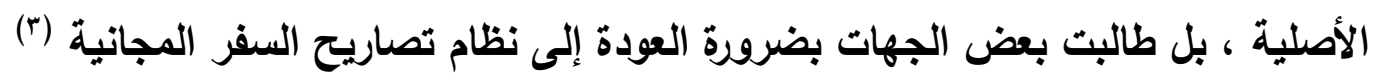

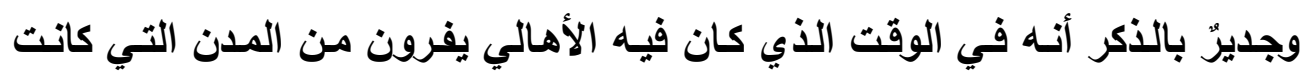

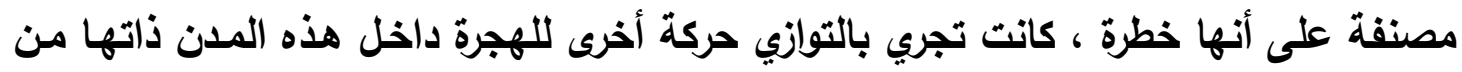

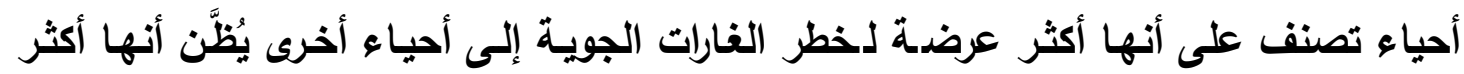

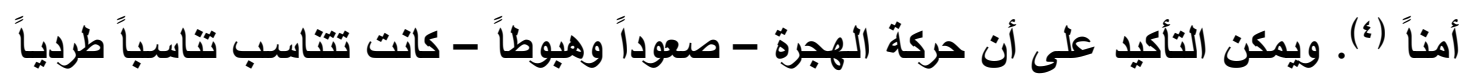

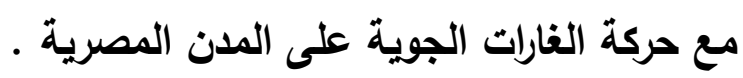

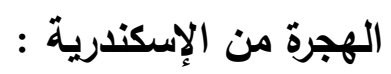

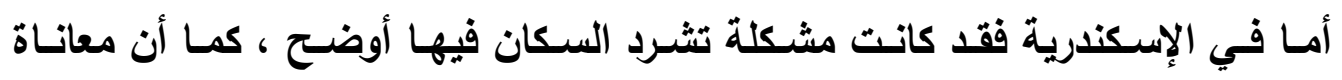

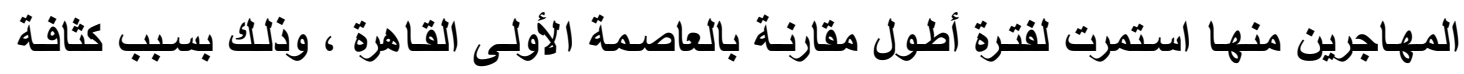

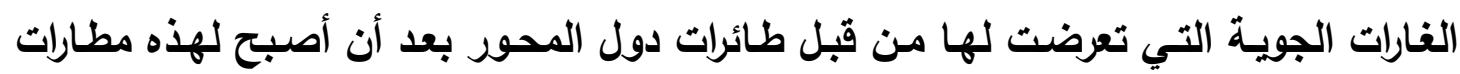

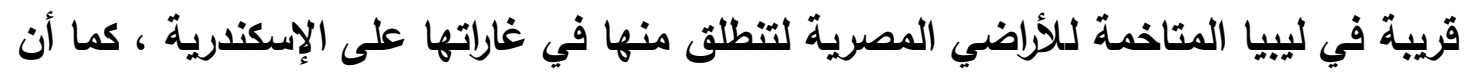

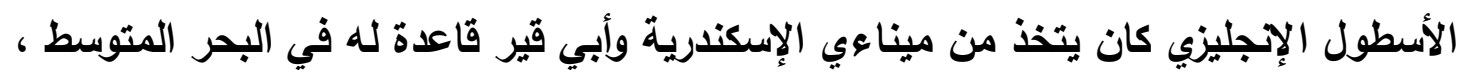

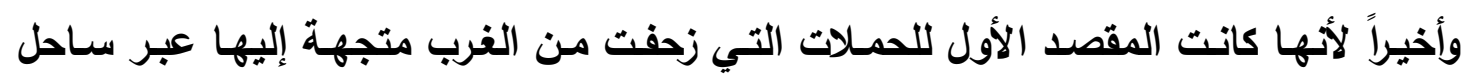
البحر المتوسط (0)

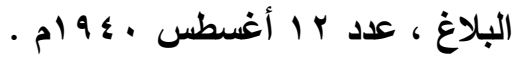

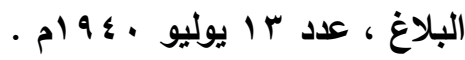

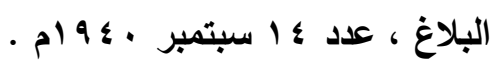

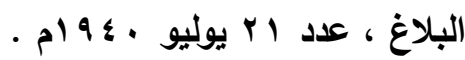

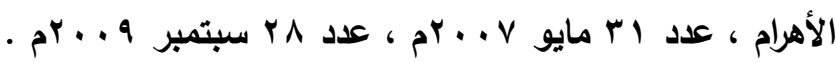


والمراقب لتطور الأحداث يلحظ أن الإدارة المصرية لم تكن تعي جيداً تلكك الحساسية الثديدة التي يتميز بها موقع الإسكندرية وأنها قد تكون بين لحظة وأخرى عرضة لطادئ لطائرات

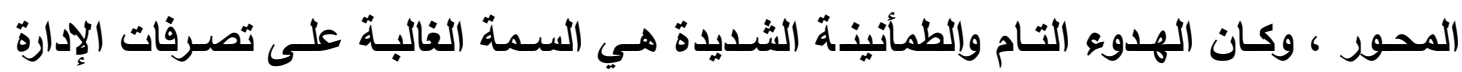

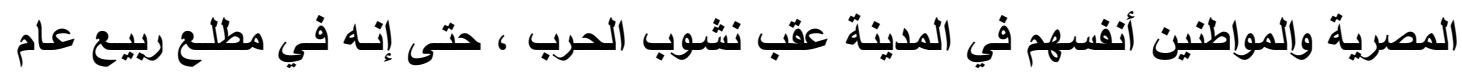

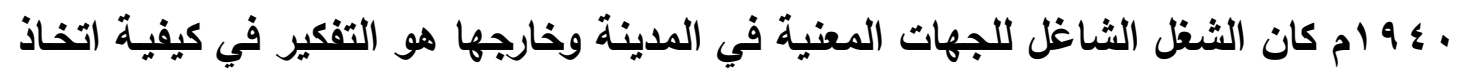

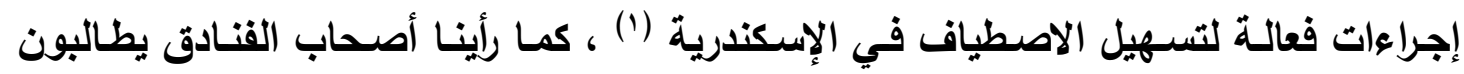

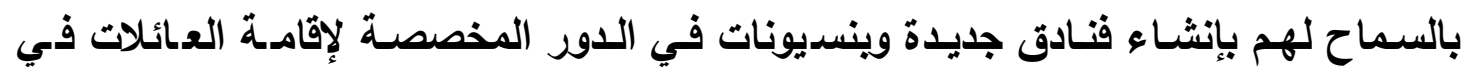

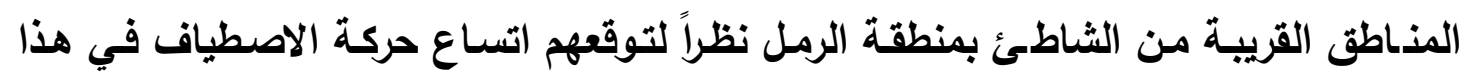

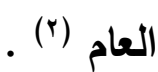
ولكن بدلاً من أن يتقاطر الناس على الإسكندرية في فصل الصيف ليتنسموا هواءها

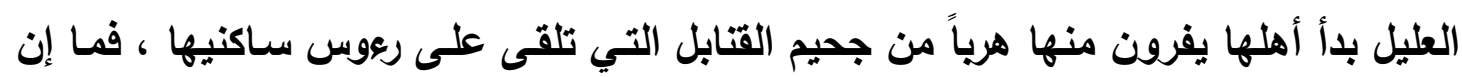

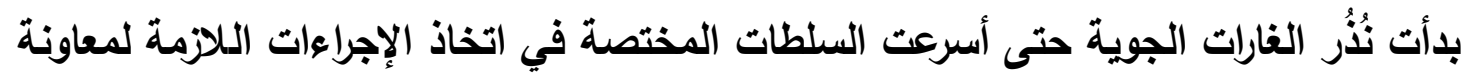
الراغبين في الهجرة من السكان ، وانهمك مكتب الوقاية من الغارات الجوية في الإسكندرية في الغئي

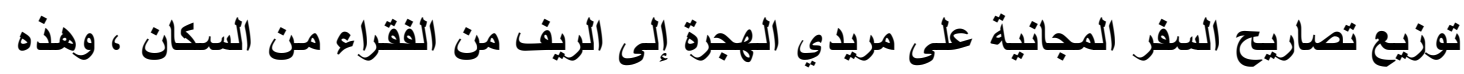

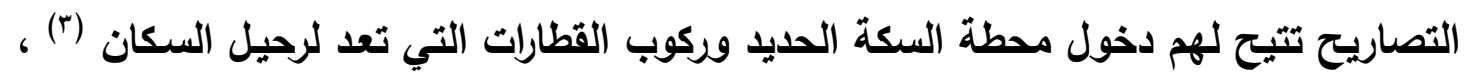
وقد تمكن موظفو المكتب بعد سـاعاتٍ من العمل المتواصل من الانتهاء من قاعدة البيانات

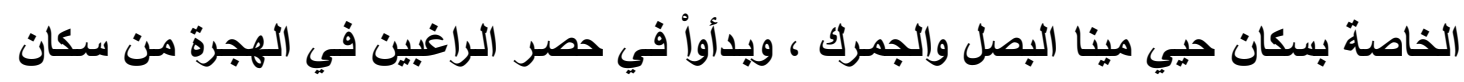

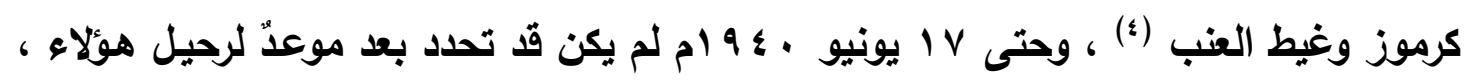

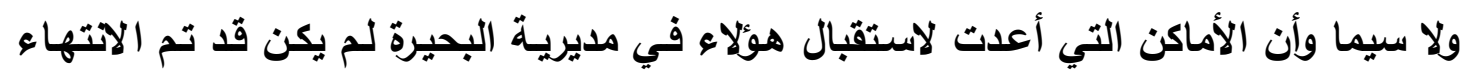

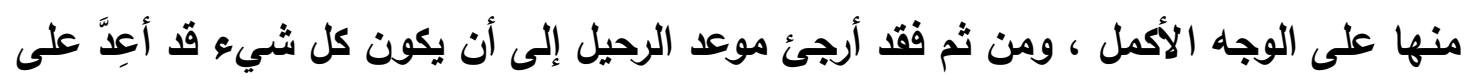

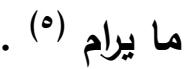

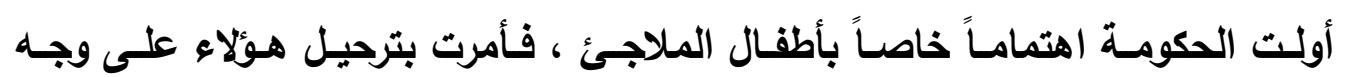

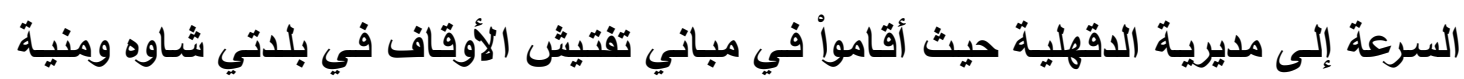

$$
\begin{aligned}
& \text { البلاغ ، عدد ه أبريل • ؛ } 9 \text { ام . }
\end{aligned}
$$

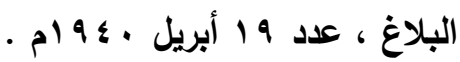

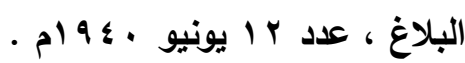

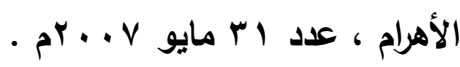

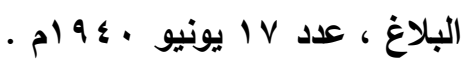


سندوب (1) ، وإذا كان الترحيل الذي ترعاه الحكومة لم يبدأ بعد فإن عدداً كبيراً من الأهالي لم

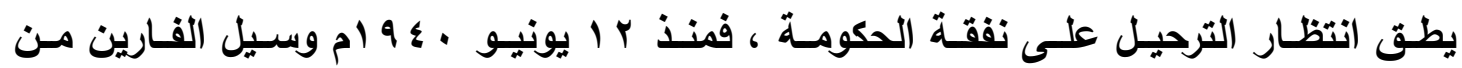

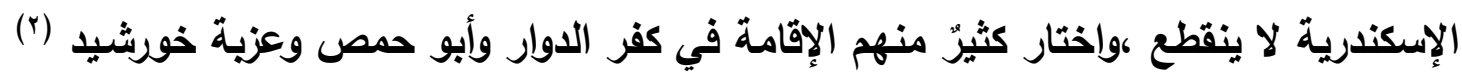

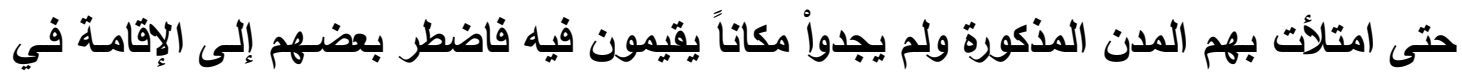

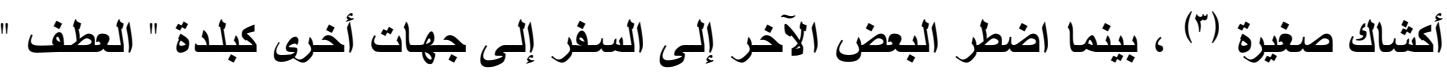
(4) ، والمحمودية (0) ، وآثرث عائلات كثيرة الرحيل إلى طنطا والمنصورة لوفرة المساكن فيها

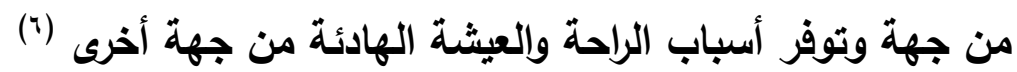

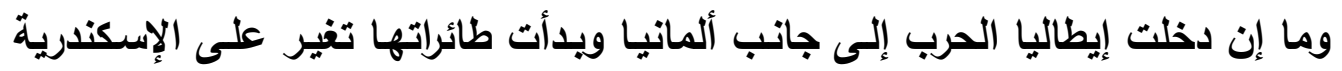

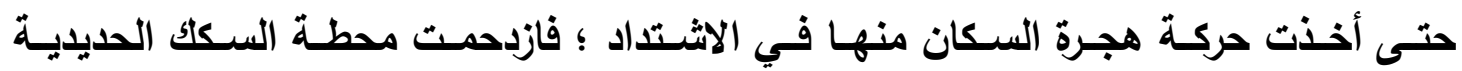
بالمهاجرين حتى لم يتبق فيها موضع لقدم ، ورغم تسيير قطارات إضافية إلا إن الزحام ظل فئل مستمراً حتى اضطر كثيرون إلى افتراش أرض المحطة إلى أن يتاح لهم في الصباح الحصول

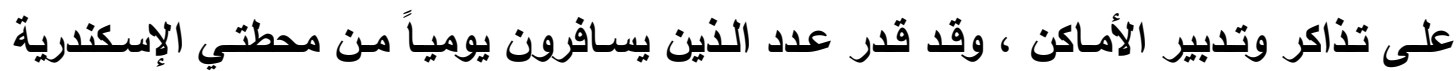

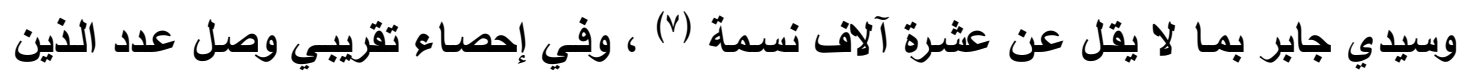

البلاغ ، عدد 1 ا يونيو ·ـ 9 ام ، وشاوه ومنية سندوب كلتاهما من قرى مركز المنصورة - مديرية

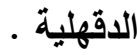

انظر : محمد رمزي : " القاموس الجغرافي للبلاد المصرية من عهـ قدماء المصريين إلى سنة

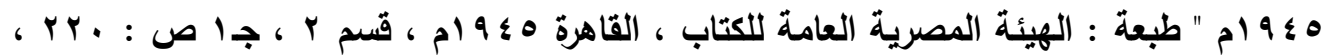
RY

تنسب عزية خورشيا إلى منشئها محمد باشا خورشيد الذي كان مديراً للسكك الديدية في زمن

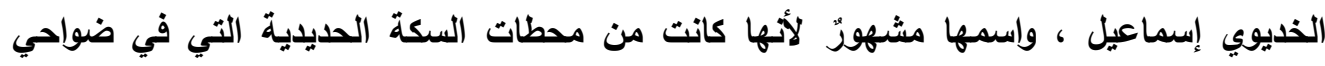

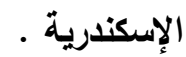

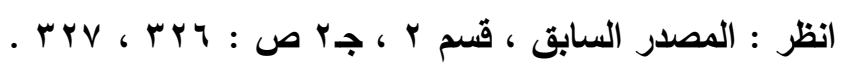

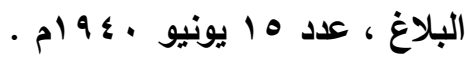

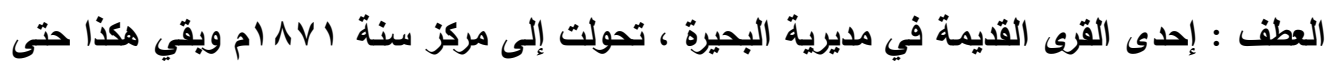

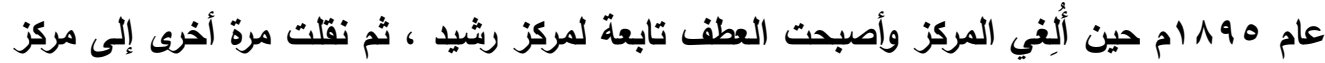

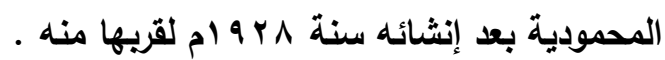

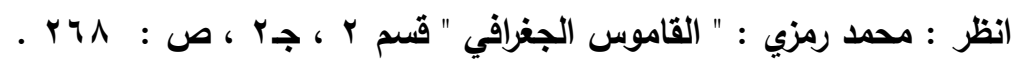

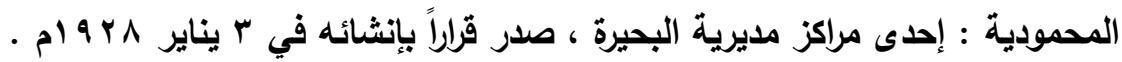

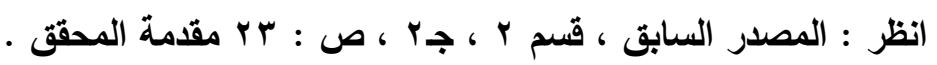

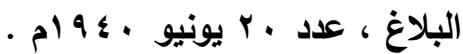

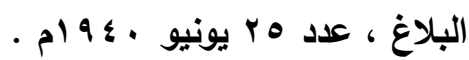


رحلواً عن الإسكندرية بالسكك الحديدية وغيرها من وسائل الانتقال إلى داخلية القطر المصري

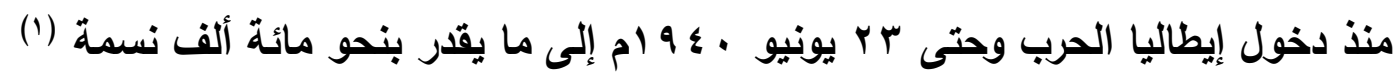

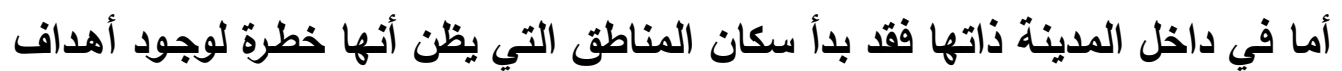

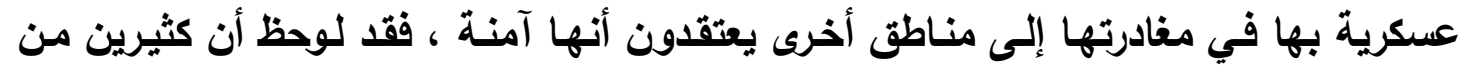

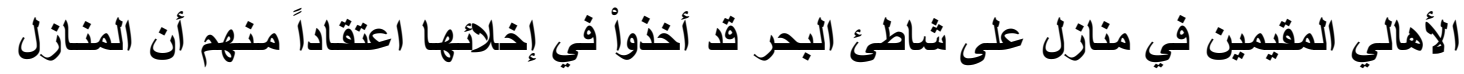

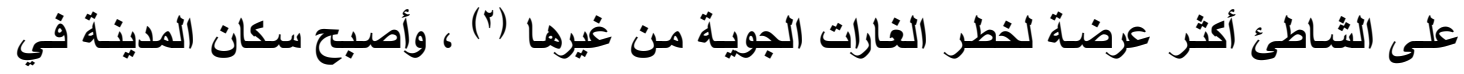

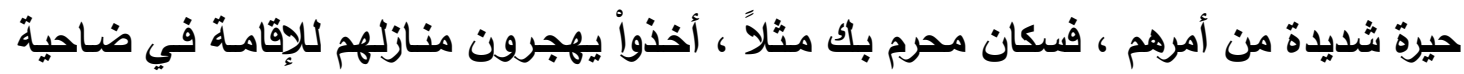

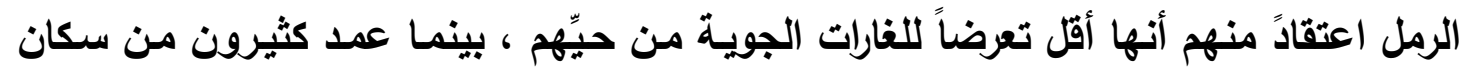

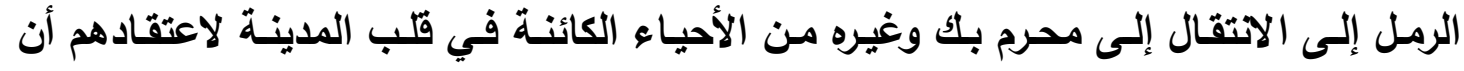

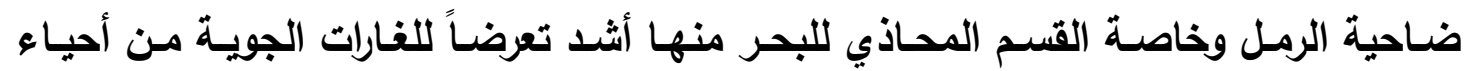

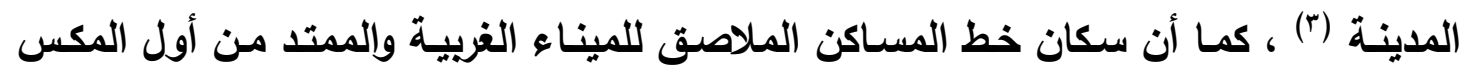

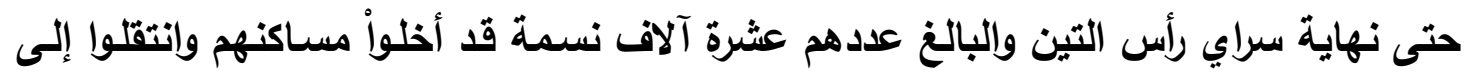

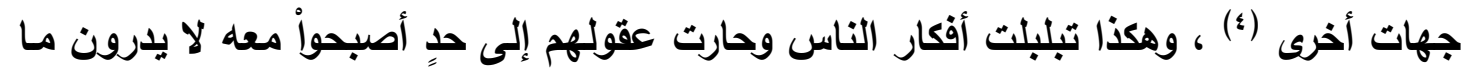
يفعلون .

ولم يكن الفرار من المدينة مقصوراً على المصريين بل إن عائلات أجنبية كثيرة سافرت

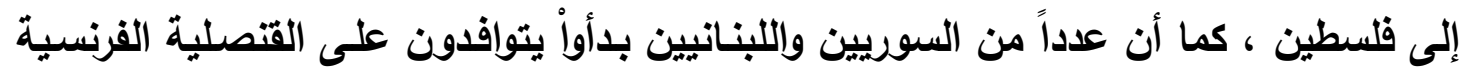

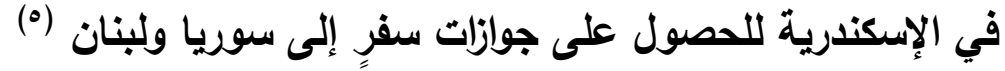

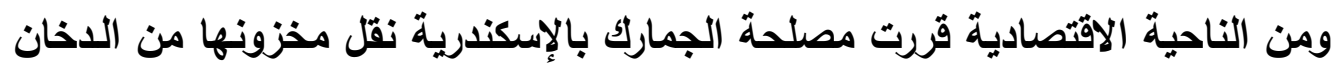
من المخازن الجمركية إلى مناطق آمنة داخل القطر مثل طنطا ودمنهور وغيرها ، كما قررت

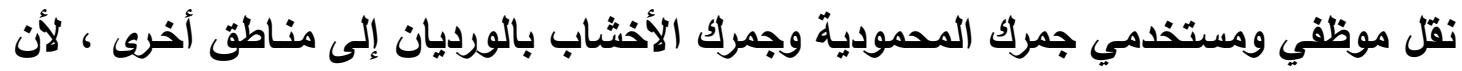

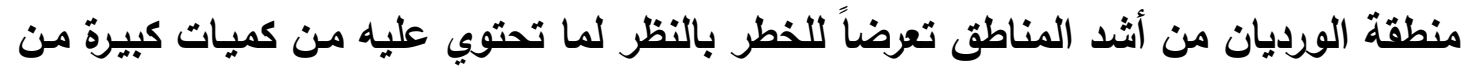

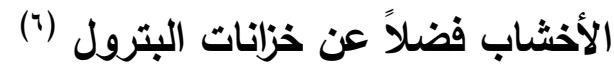

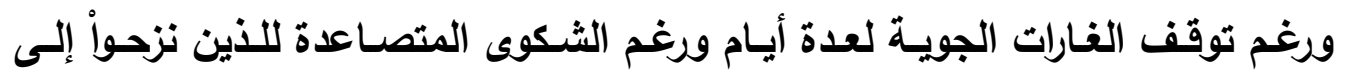
الأرياف من أهل الإسكندرية من مصاعب الحياة هذاك بسبب ارتفاع أجور المساكن وانعدام

$$
\begin{aligned}
& \text { البلاغ ، عدد بآ يونيو · ـ } 9 \text { ام . }
\end{aligned}
$$

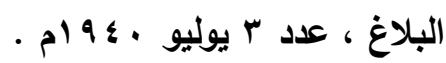

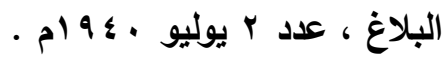

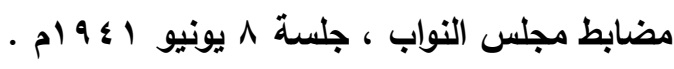

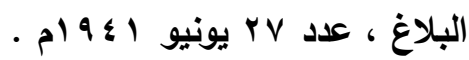

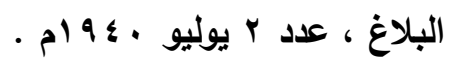


وسائل الراحة وقلة المياه الصالحة للشرب وشتح العناية الصحية وغير ذلك فقد استمرت هجرة

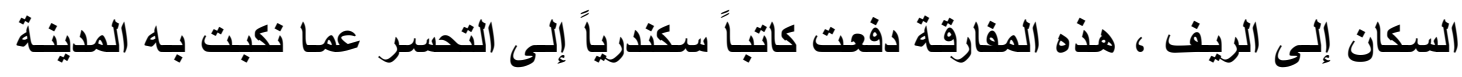

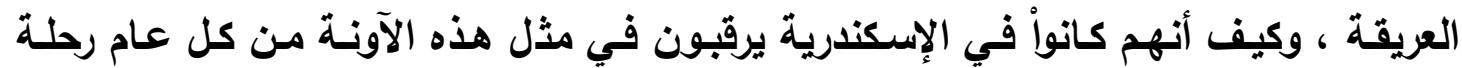

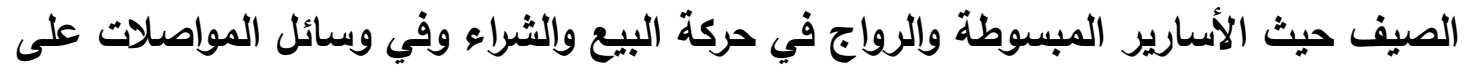

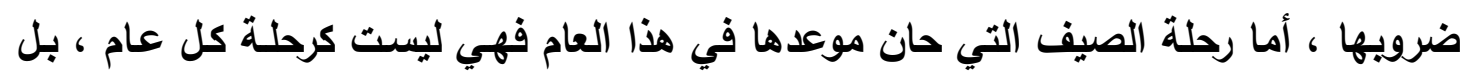

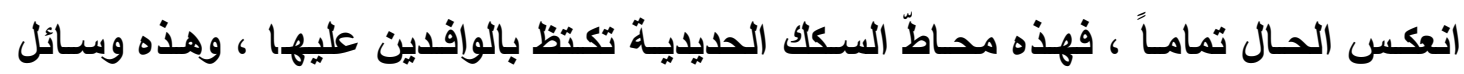

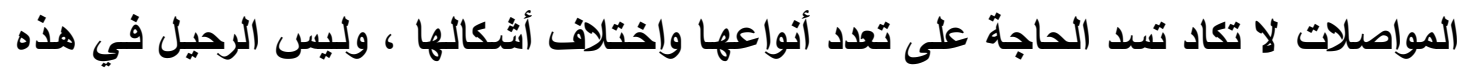

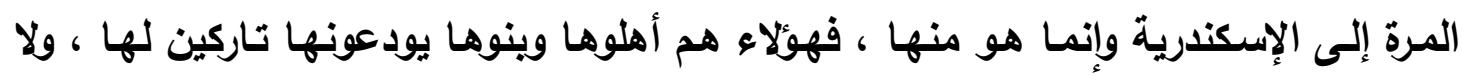

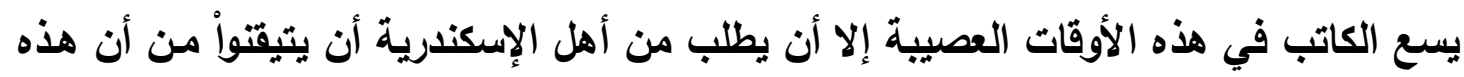

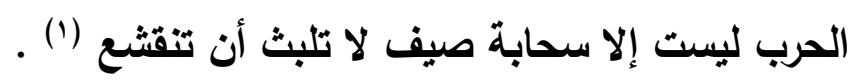

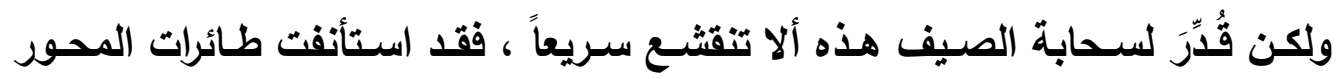

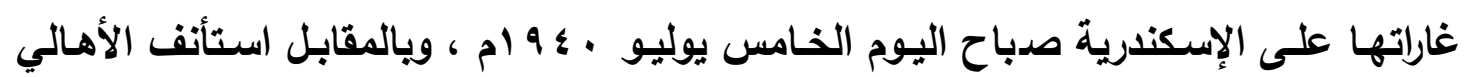

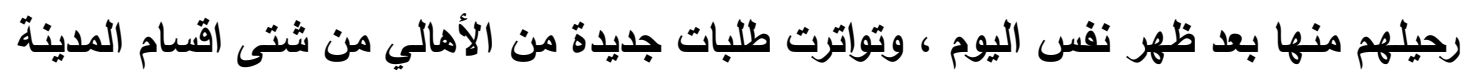

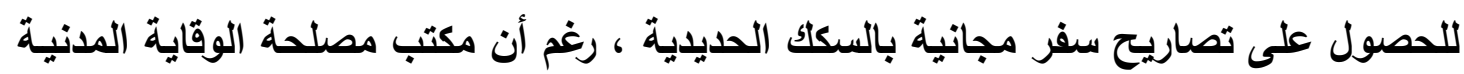

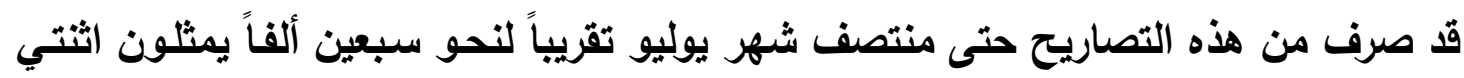

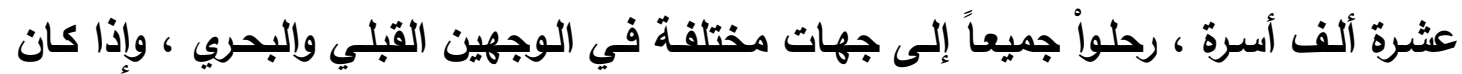

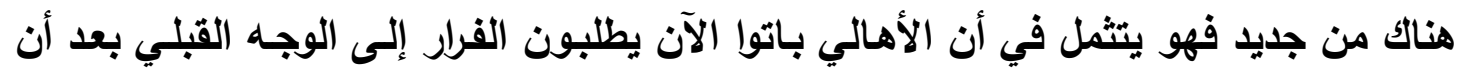

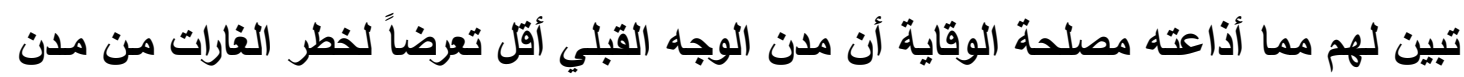
الوجه البحري (†) ، وأخيراً يستيقظ أحد الأعضاء في مجلس النواب من سباته فيقدم استجواباً التها

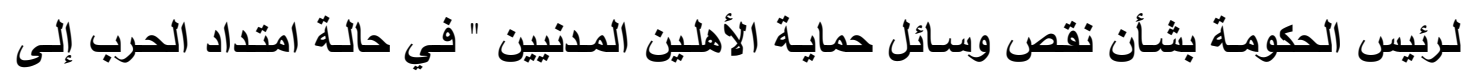

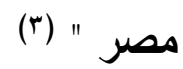

وتؤكد الإحصاءات أن عدد الراحلين من مدينة الإسكندرية بلغ نحو أربعة آلاف يومياً بواسطة السكك الحديدية عدا الذين يرحلون بوسائل النقل الأخرى ، ويصل من هؤلاء الراحلين الألئل

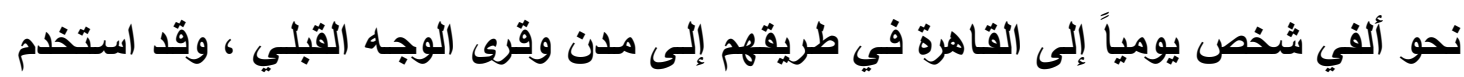

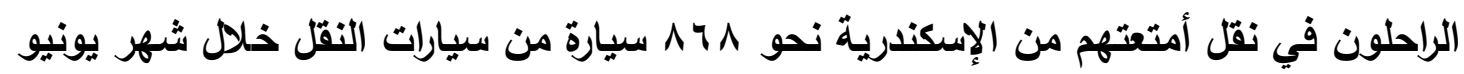

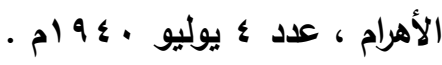

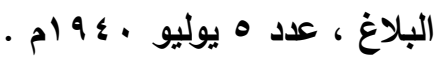

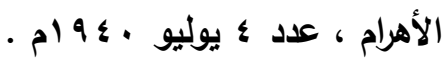




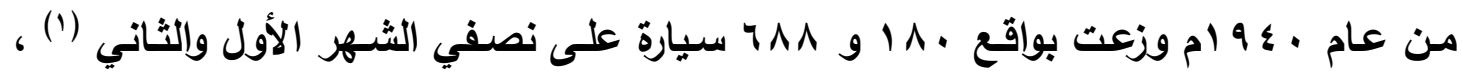

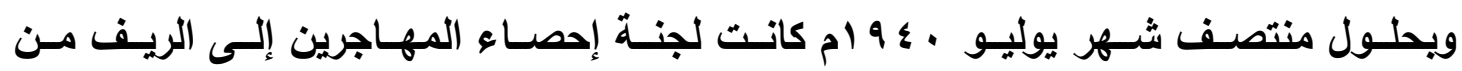

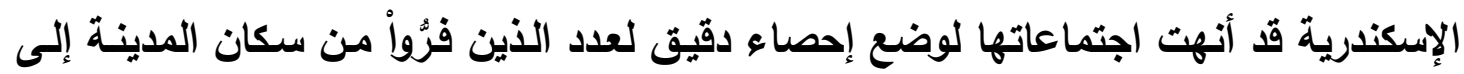

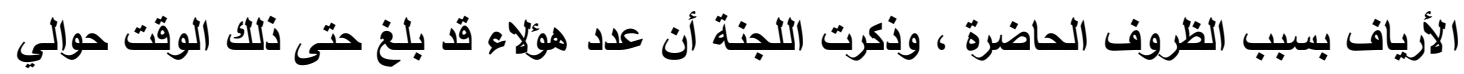

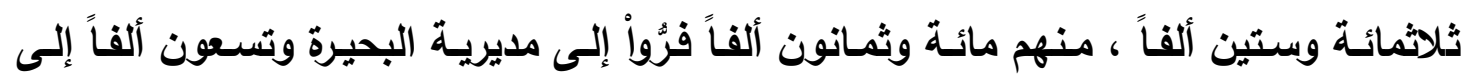

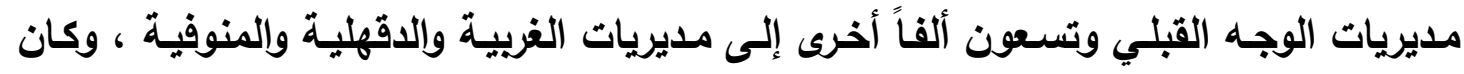

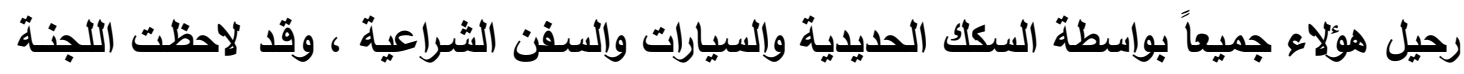

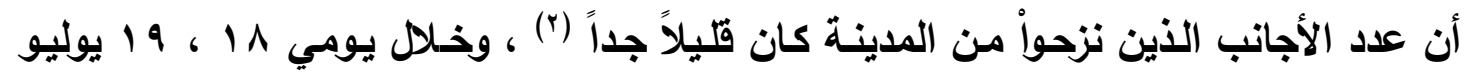

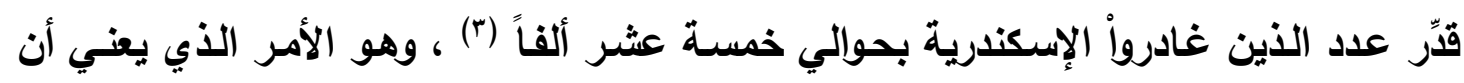

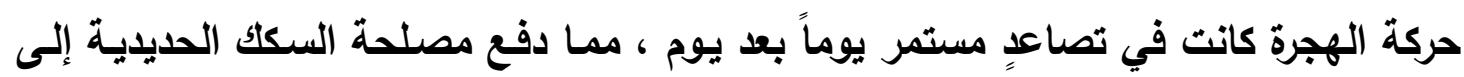

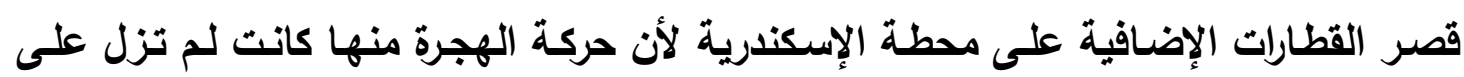

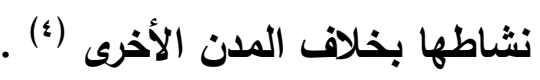
كانت المصاعب الماليـة والصحية التي واجهها الراحلـون إلى الريف فوق طاقتهم

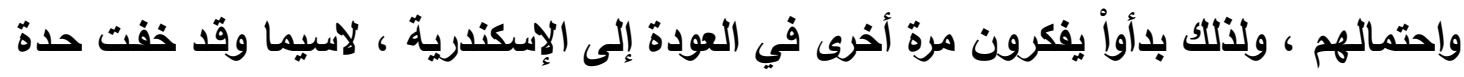

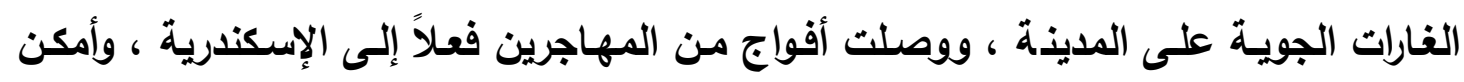

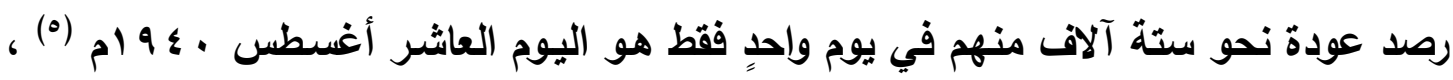

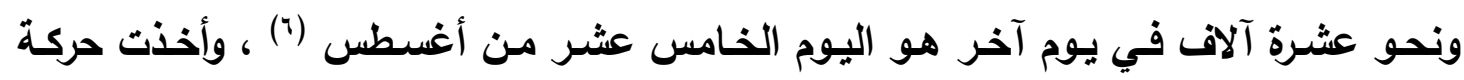

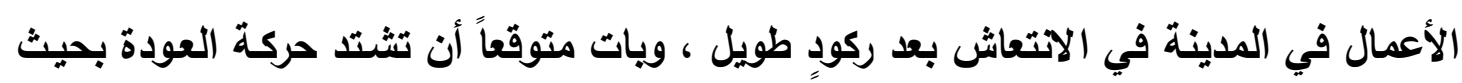

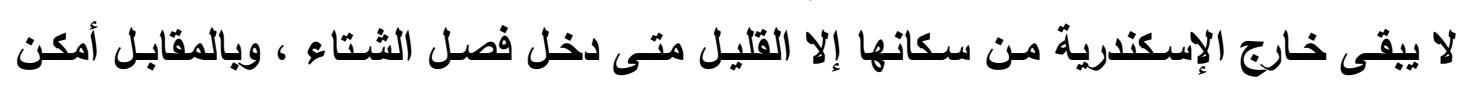

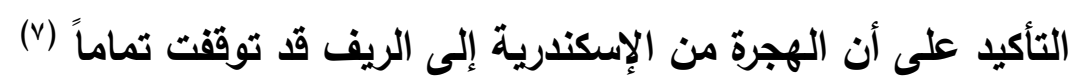

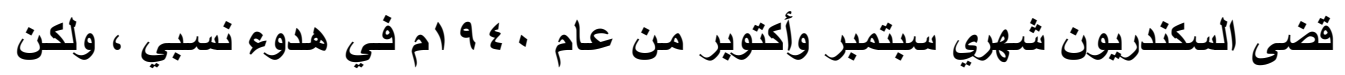

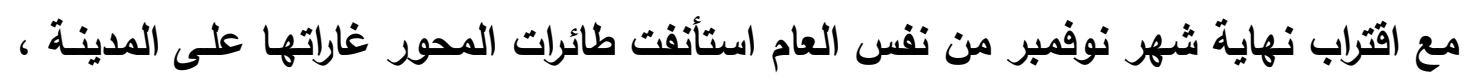

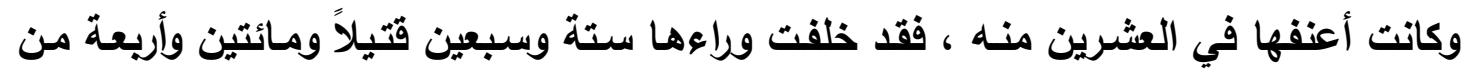

$$
\begin{aligned}
& \text { البلاغ ، عدد ^ يوليو · ؛ } 9 \text { ام · }
\end{aligned}
$$

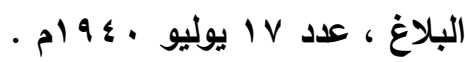

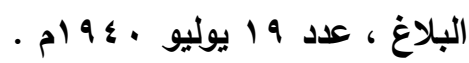

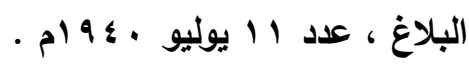

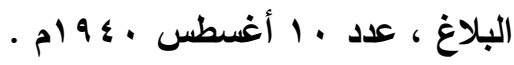

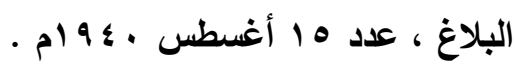

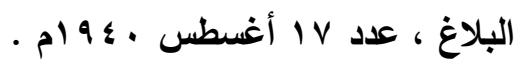


الجرحى (1) ، ويدأت حركة الهجرة من الإسكندرية تنشط من جديد ، وتقرر زيادة عدد القطارات

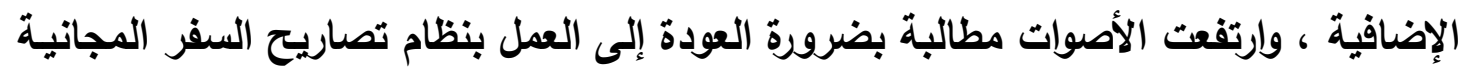
بعد وقفها (ץ) ، وأقدم المسؤولون عن الأزهر الثريف على إجراء احترازي - طلباً للسـلامة -

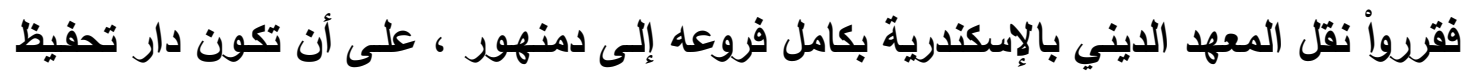
القرآن بتلك المدينة مقراً له ، كما منحو طلابه عطلة دراسية لمدة سبعة أيام ، وسـارت وزارة

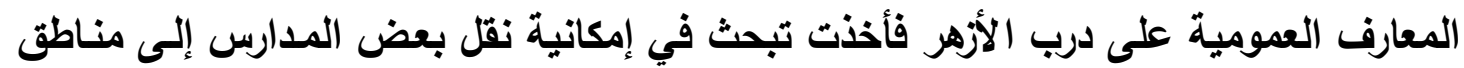

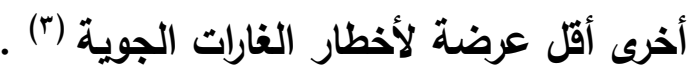

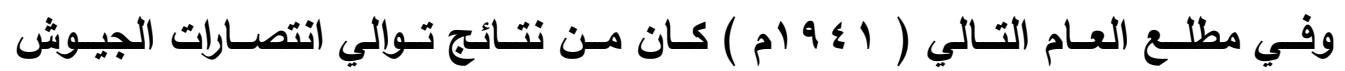

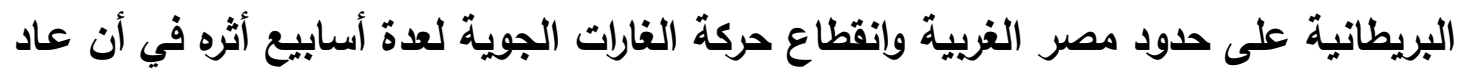

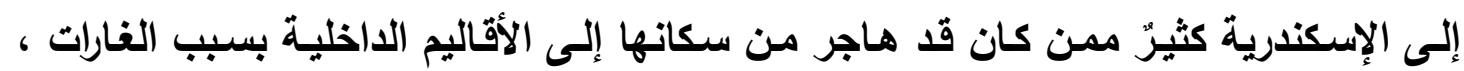

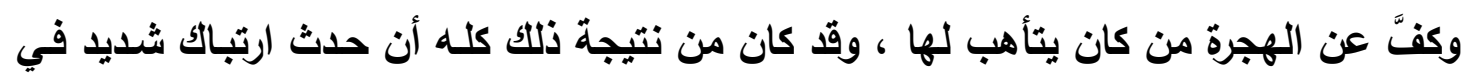

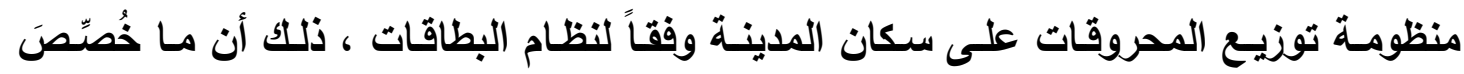

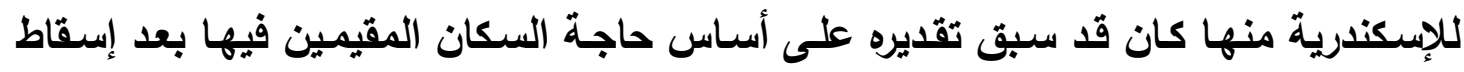

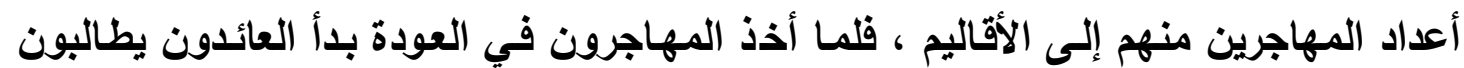

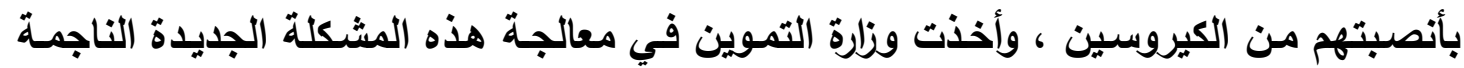

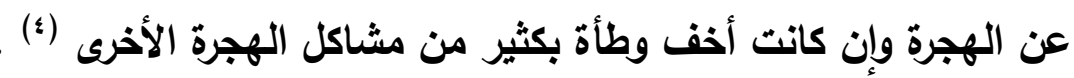

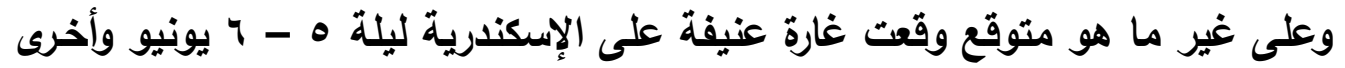

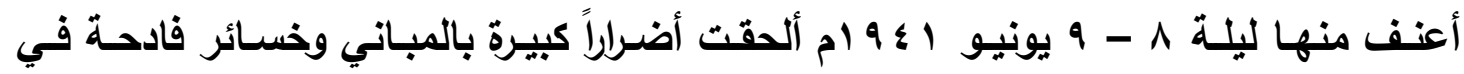

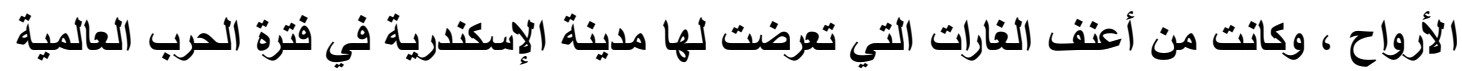

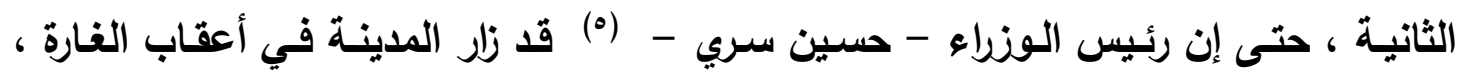

$$
\begin{aligned}
& \text { البلاغ ، عدد ؛ ب نوفمبر · ـ } 9 \text { ام . }
\end{aligned}
$$

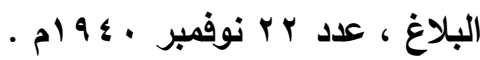

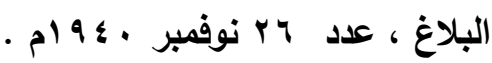

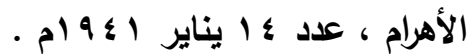

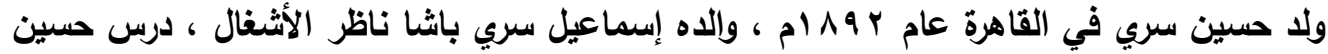

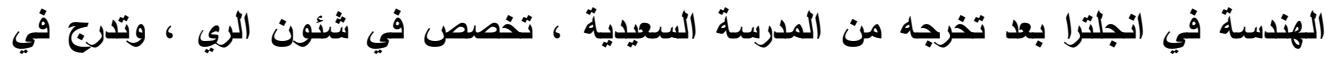

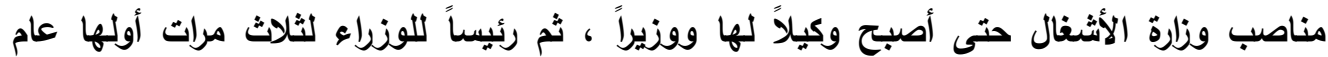

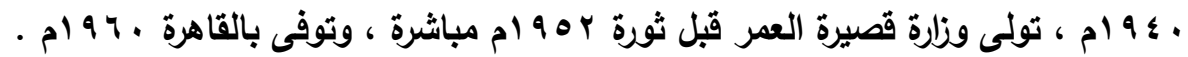

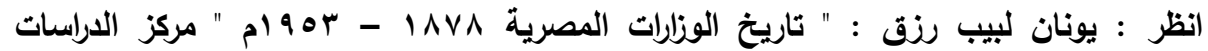

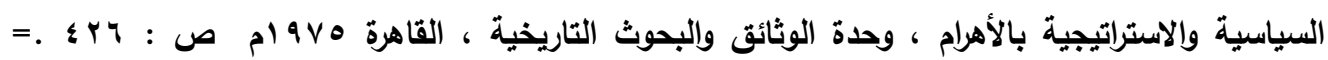


وأصدر - بوصفه الحاكم العسكري العام - عدة أوامر كان لها أثرّر فعالٌ في ترحيل المهاجرين ،

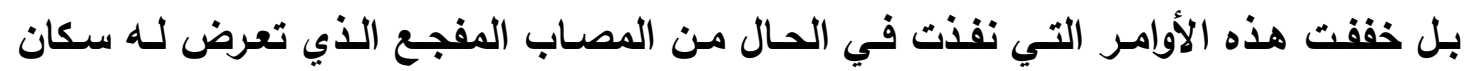

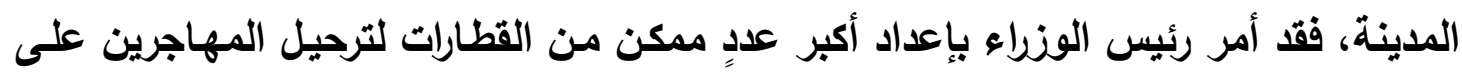

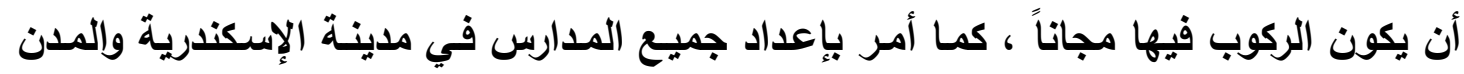

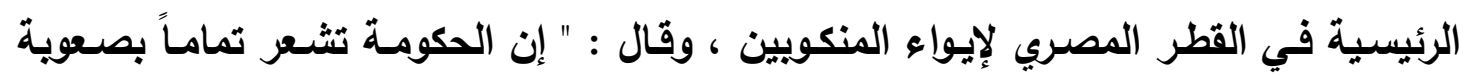

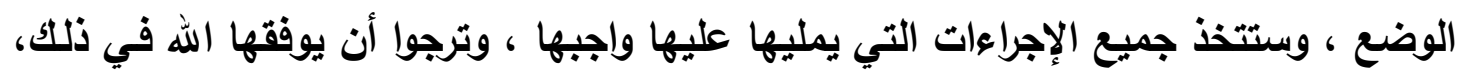

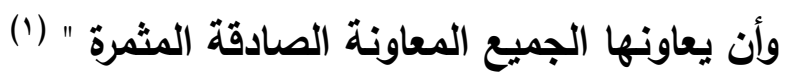

والحق إن الآثار التي ترتبت على هاتين الغارتين كانت كارثية ، ولم يكن بإمكان أقوى أهمان

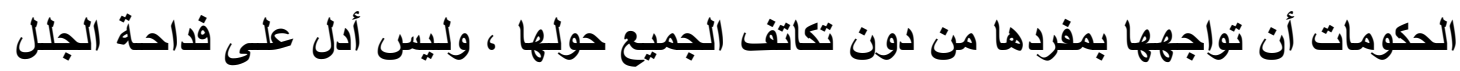

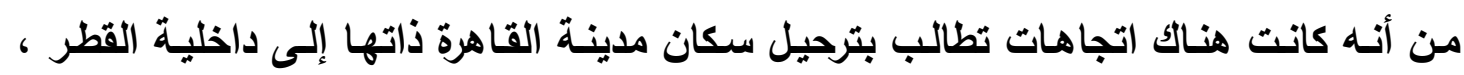

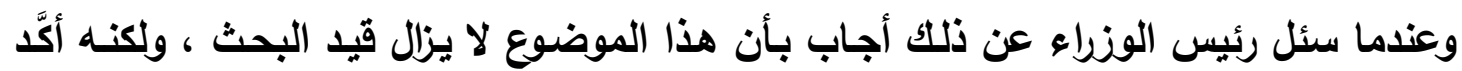

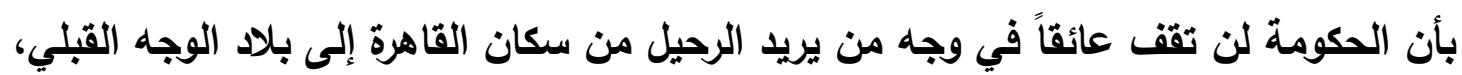

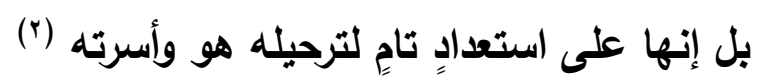

=وانظر كذلك : شميت ، آرثر جولا: " قاموس تراجم مصر الحديثة " ترجمة وتحقيق : عبد الوهاب

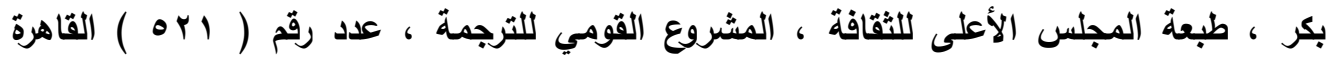
.

والجدير بالذكر أنه قد تعاقب على حكم مصر خلال فترة الحرب العالمية الثانية عدة وزارات

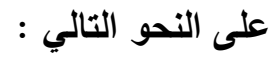

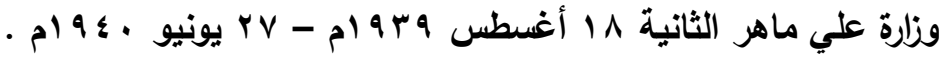

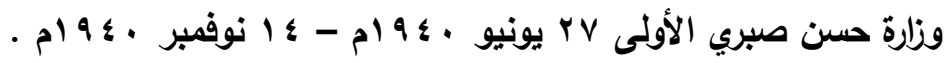

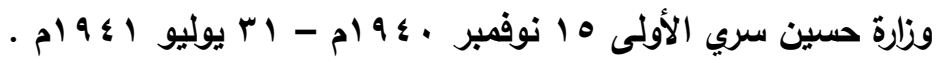

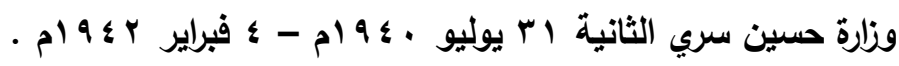

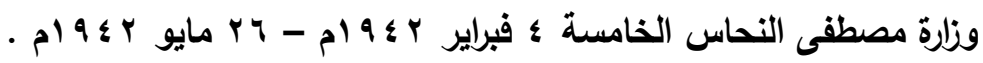

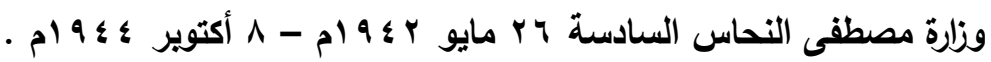

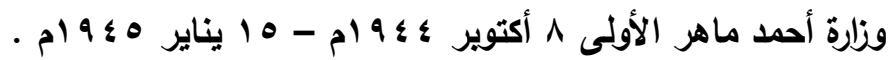

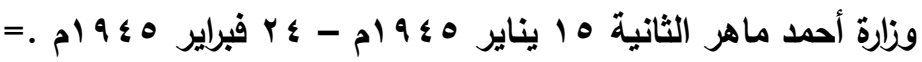

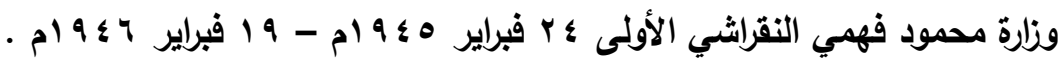

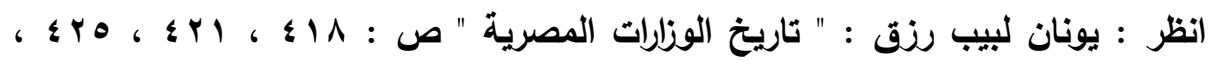

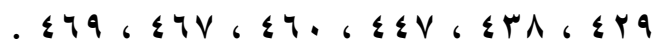

$$
\begin{aligned}
& \text { البلاغ ، عدد ^ يونيو 1 } 9 \text { ام . }
\end{aligned}
$$

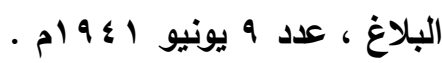


كانت المشاهد في الإسكندرية محزنة للغاية فالطرقات داخل المدينة والطرقات الزراعية

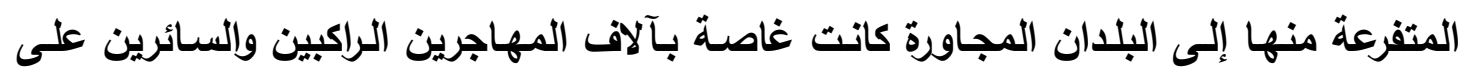
الأقدام ، وقد استخدمت جميع وسائل النقل المتاحة من السيارات ومركبات الركوب ومركبات

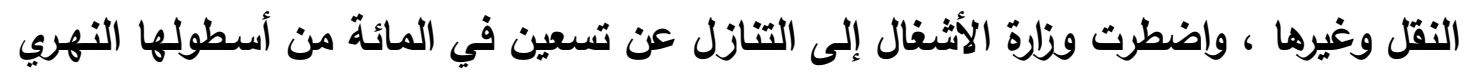
لاستخدامه في عمليـة نقل المهاجرين ، حتى إن المراكب في ترعة المحمودية حملت ثنلاث

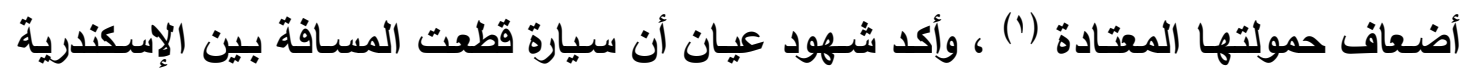

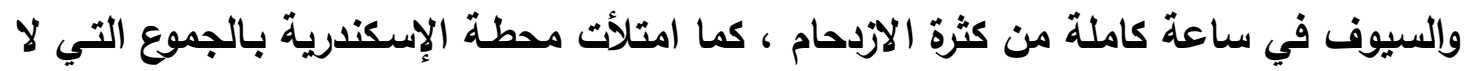

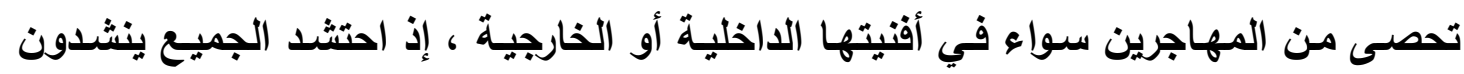

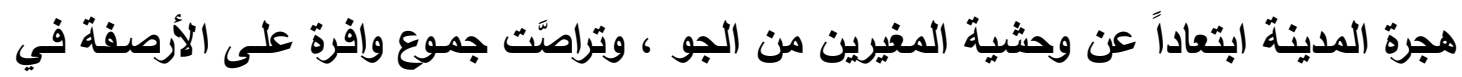

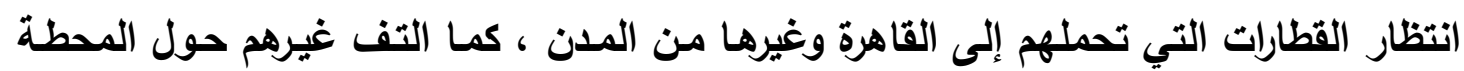
ينتظرون السفر مان وقد بذل رجال مصلحة السكك الحديدية الجهد في تيسير وسـائل النقل ، واستعانواً

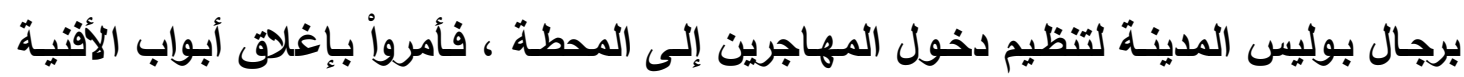
اللاخلية للمحطة ، وكذلك الأفنية الخارجية بحيث لا يسمح بالاخول إلى أرصفة المحطة إلا كل

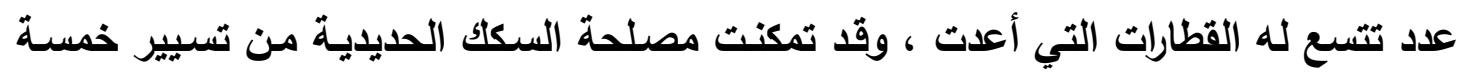

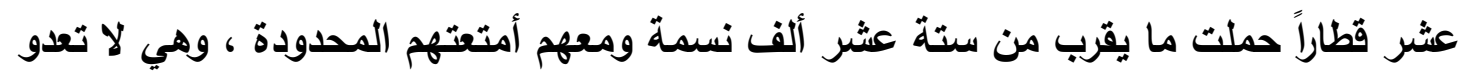

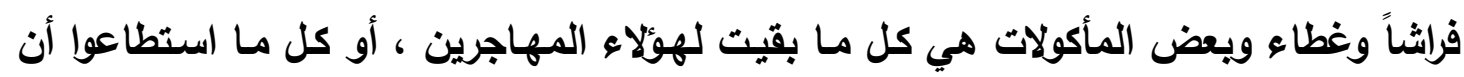

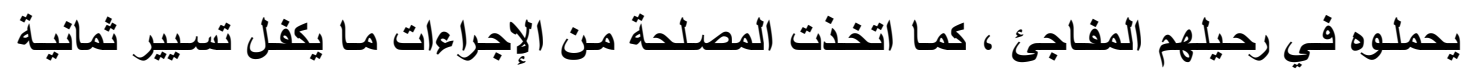

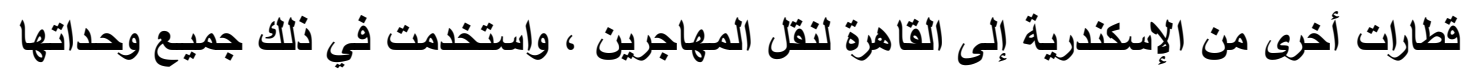

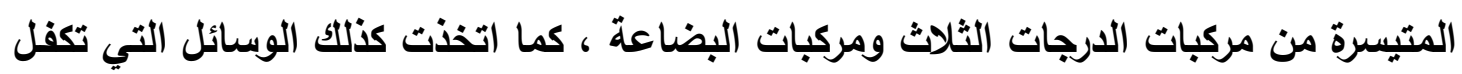

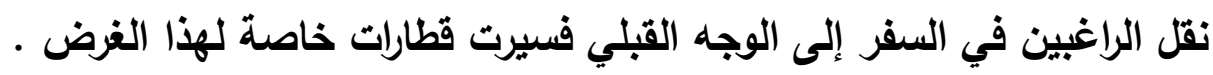

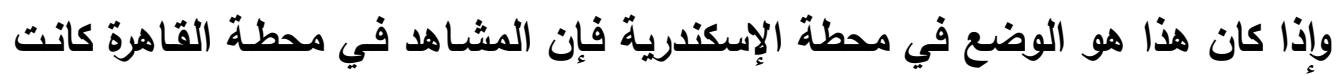

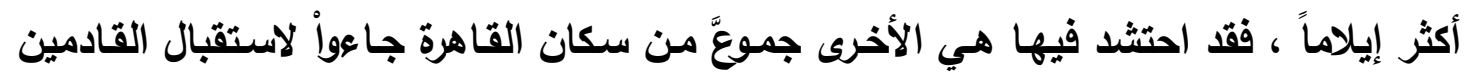

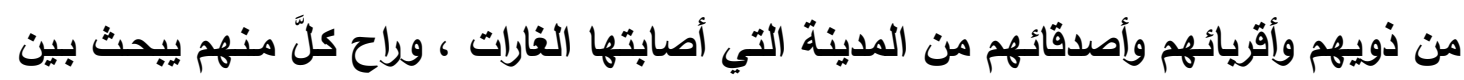

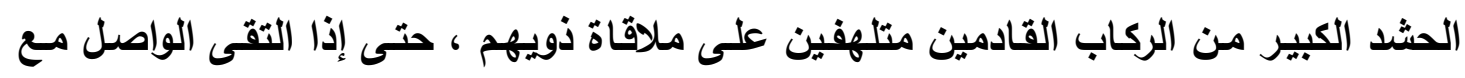

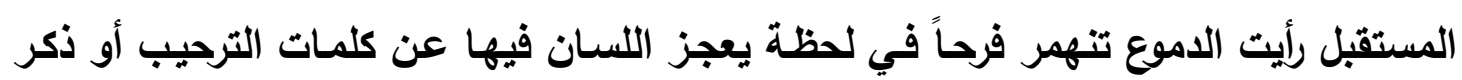

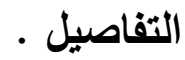
أمسا الأمهات الوالهات فكانت لا تستقر عيونهن في البحث عن أبنائهن مـن بين 
القادمين ، فإذا لم يصل من ينتظرنه من ركاب القطار انهمرت دموعهن ورحن ينتظرن القطار

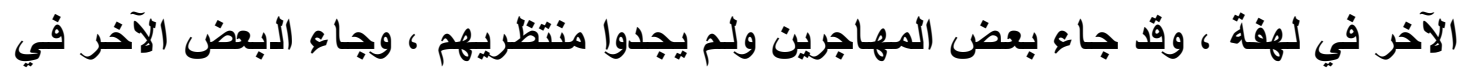

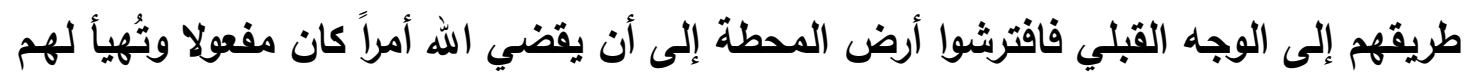

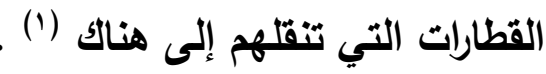

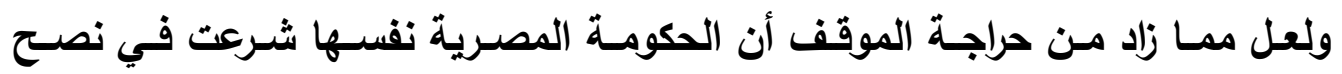

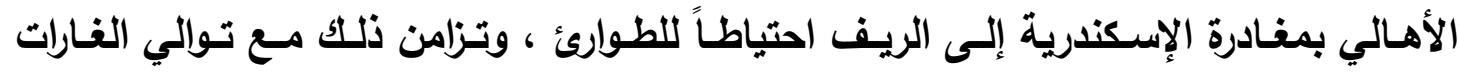

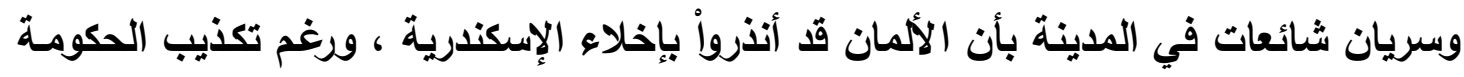

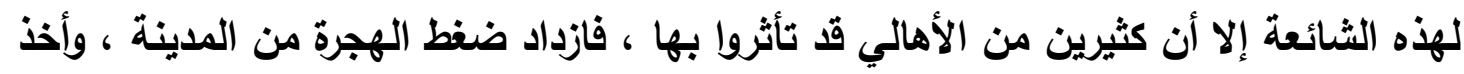

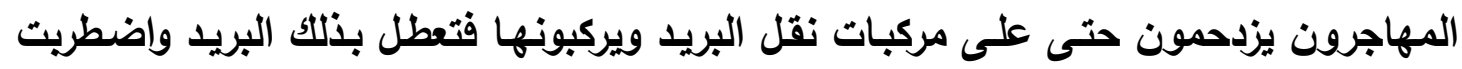

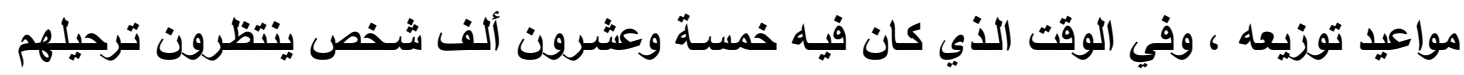

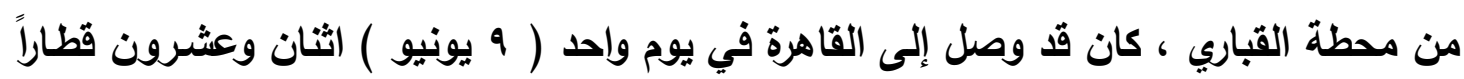

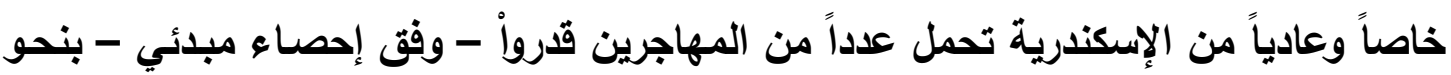

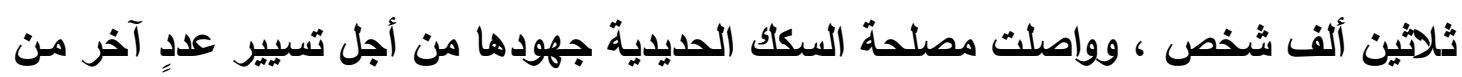

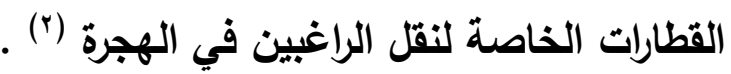
أما من بقي في الإسكندرية من أهلها واستبعدواً فكرة الهجرة فقد عانواً بدورهم ظروفاً

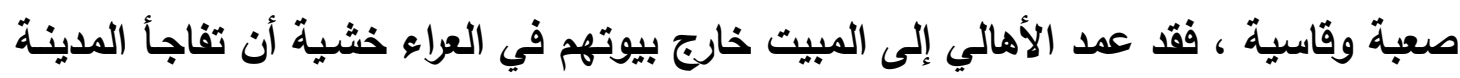

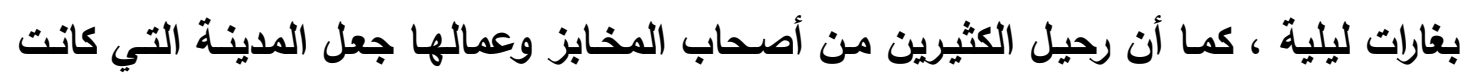

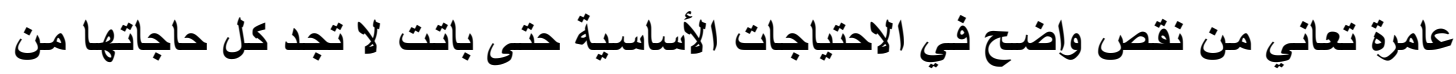

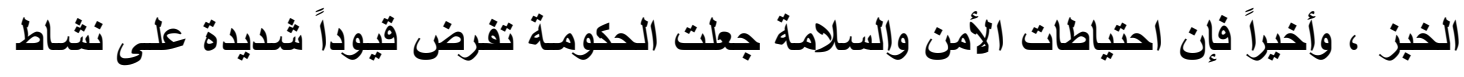

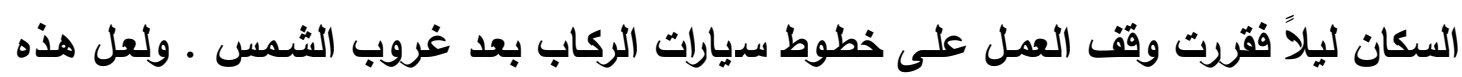
الأوضاع هي التي دفعت عدداً من أعضاء مجلس النواب لتقديم ثُلاثتة استجوابات برلمانيـة بخصوص تهاون الحكومة في اتخاذ الوسائل الضرورية لتجنيب سكان الإسكندرية ويلات القتل

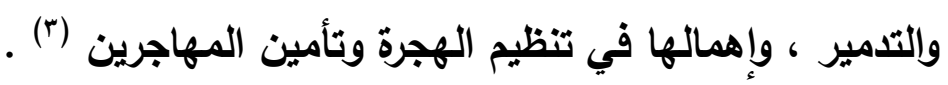

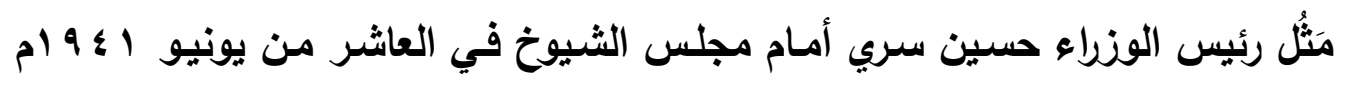

لقد أسهب محرر البلاغ في وصف المثاهد المأساوية التي رآها بعينه سواء عندما زار الإسكندرية

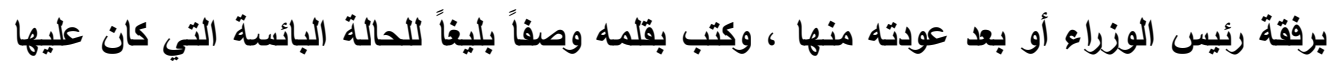

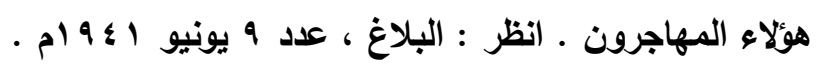

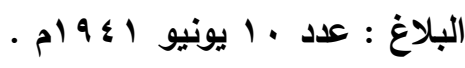

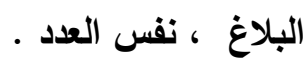


خلإقاء بيانٍ حول الغارات التي وقعت على الإسكندرية ، وقال : إن المدينة قد تعرضت لغارتين

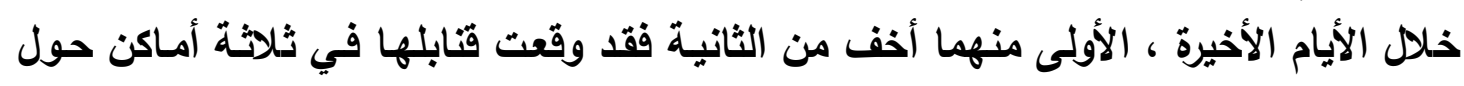

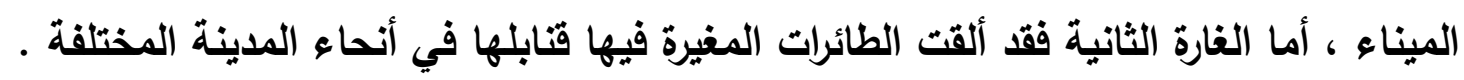

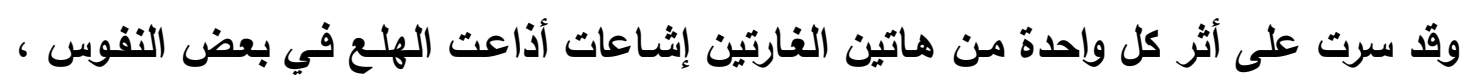

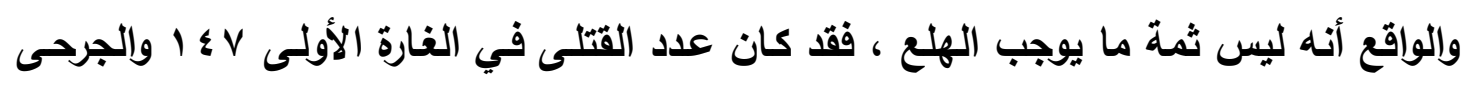

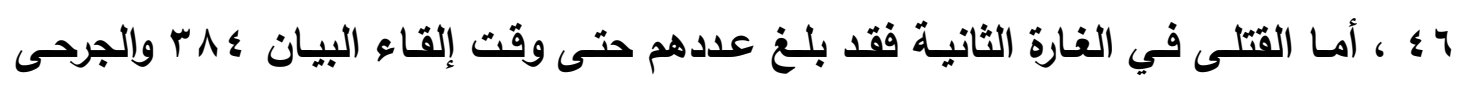

ويضيف رئيس الوزراء أن هاتين الغارتين دفعتا بكثيرٍ من أهالي الإسكندرية يقدرون

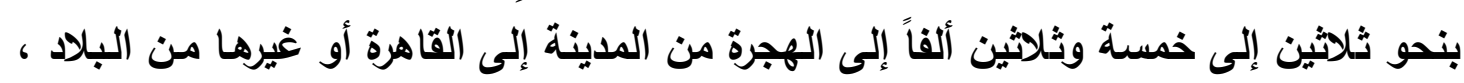

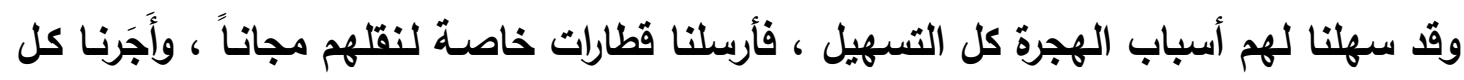

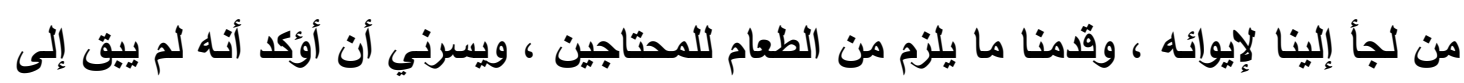

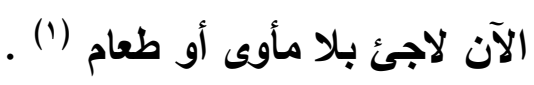

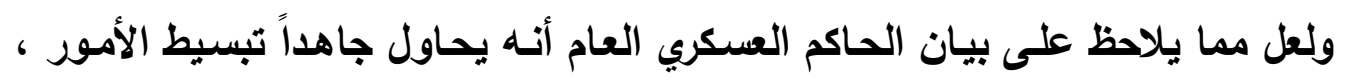

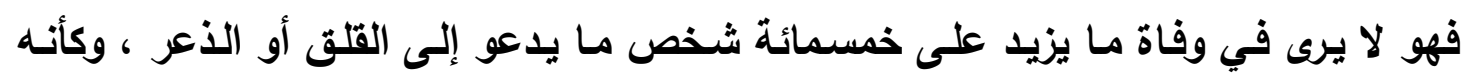

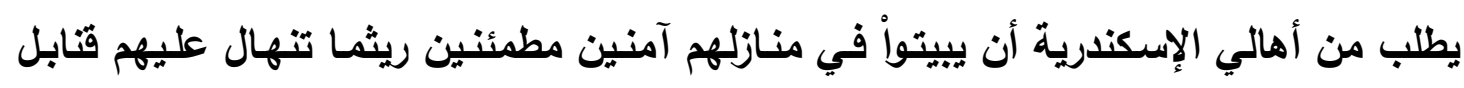

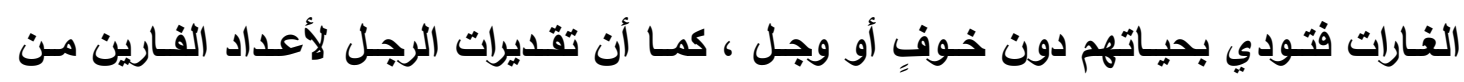

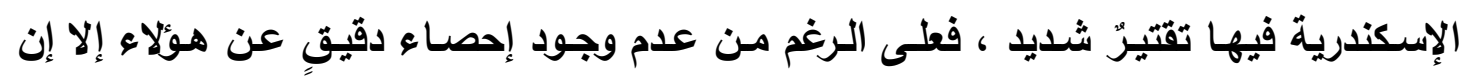

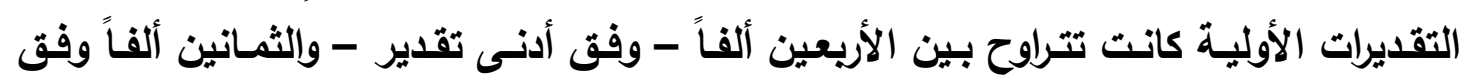

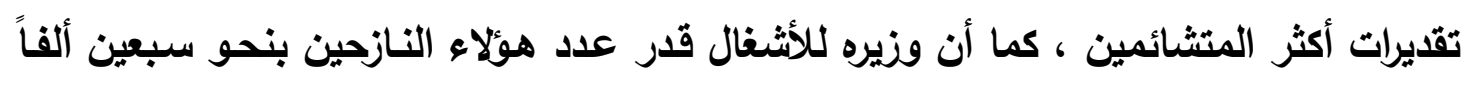

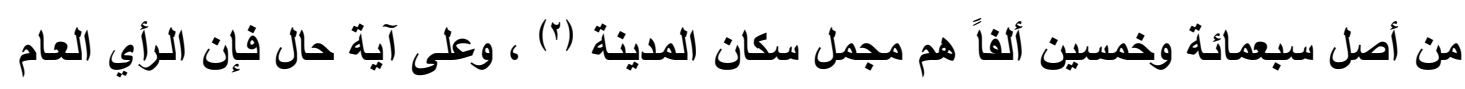

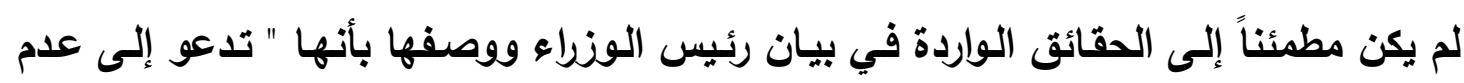

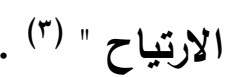

ومهما يكن من أمر فإن الحالة في الإسكندرية قد دعت الحكومـة إلى اتخاذ إجراءات

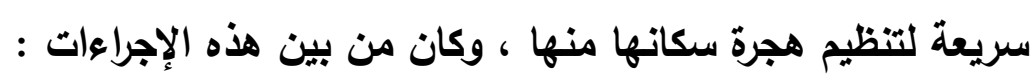

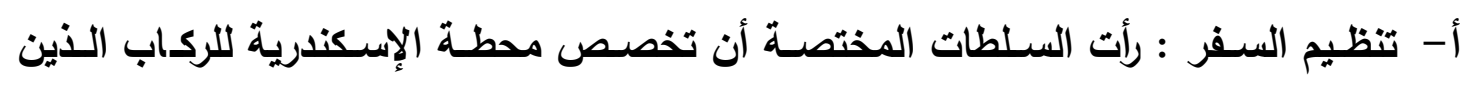

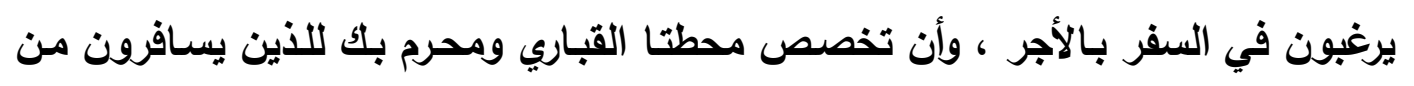

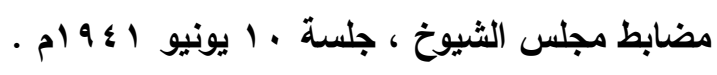

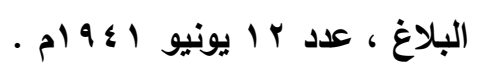

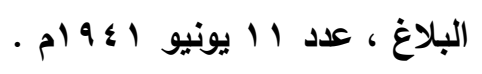


المهاجرين باون أجر وذلك رغبة منها في تنظيم عملية الرحيل .

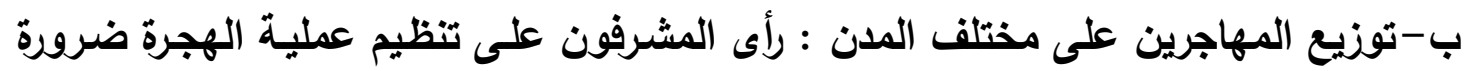
توزيع المهاجرين على مختلف جهات القطر حتى لا يتكدس المهاجرون في مدينة دون

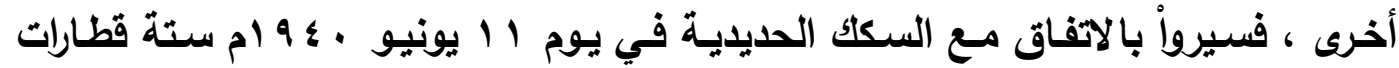

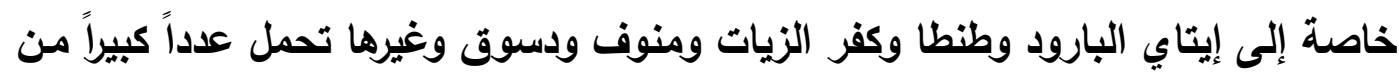

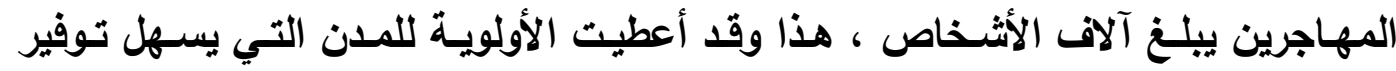
أسباب الصحة فيها ، فقد ثبت للحكومة من تجربة الهجرة في العام الماضي أن الذين نزئلواً

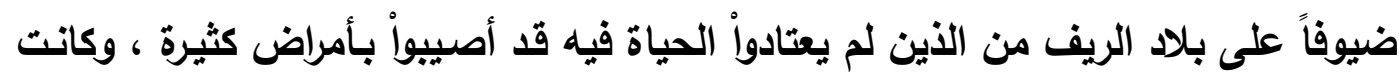

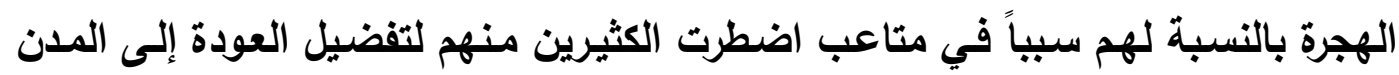

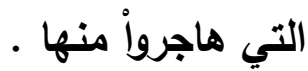
ج-توفير القطارات لنقل المهاجرين : نظراً لحاجة السكك الحديدية إلى قطارات خاصة لنقل

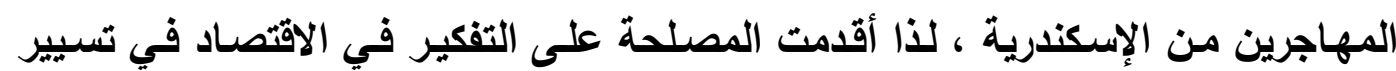
بعض القطارات التي تسير على الخطوط الأخرى ، فصدر قرارٌ بوقف تسيير تسعة عشر

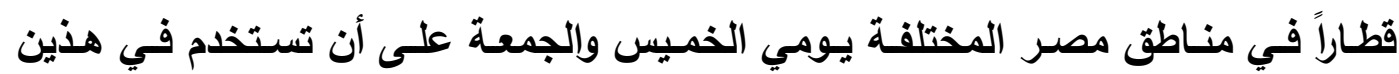

اليومين لنقل الركاب من الإسكندرية وإلقاهرة (1)

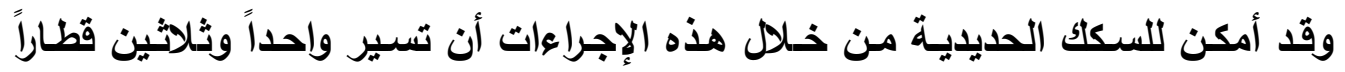

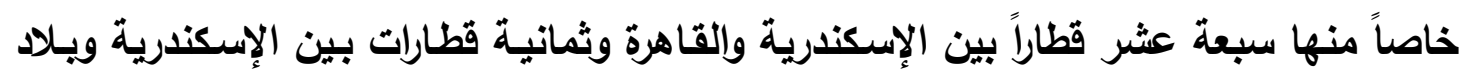

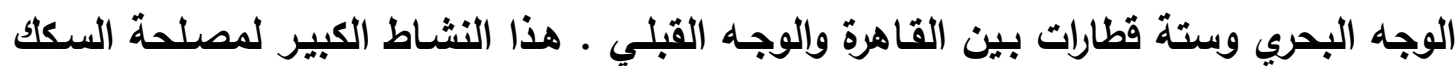

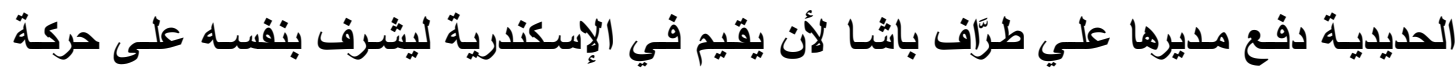

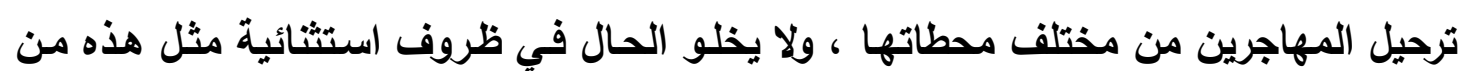

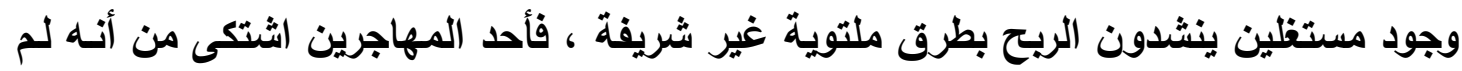

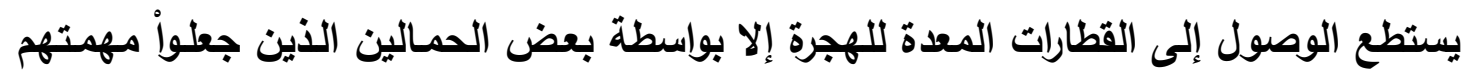

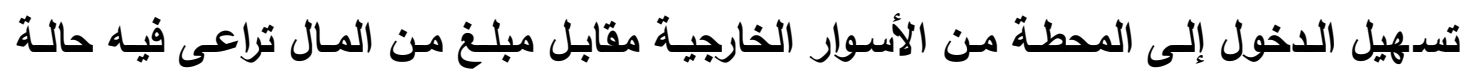

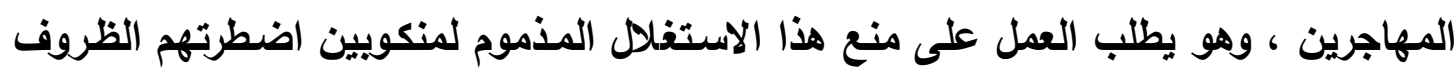

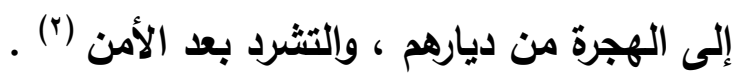

ورغم هذه السلبيات لم يكن أمام السكك الحديدية إلا أن تواصل جهن جهودها في سبيل نقل المهاجرين إلى القـاهزة فسيرت يوم 11 يونيو 19 ام ثمانيـة وعشرين قطاراً خاصـاً لنقل

$$
\text { البلاغ البلاغ ، نفس العدد . }
$$


الراحلين وذلك عدا القطارات العادية التي تسبرها عادة بين العاصمتين ثم بين العاصمة الكبرى

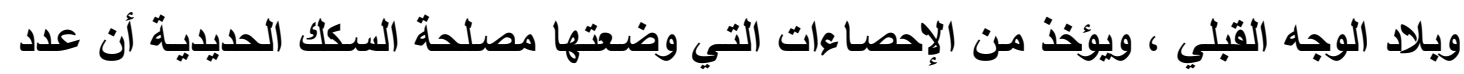

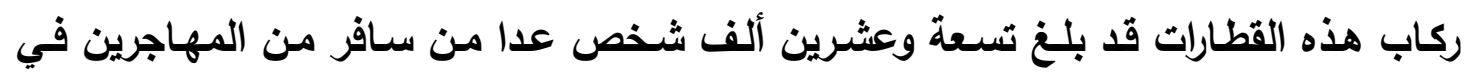

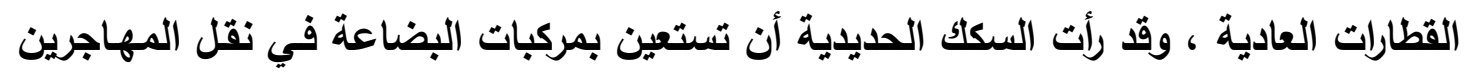

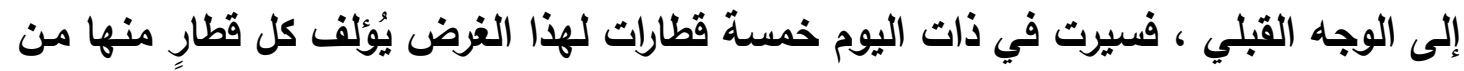

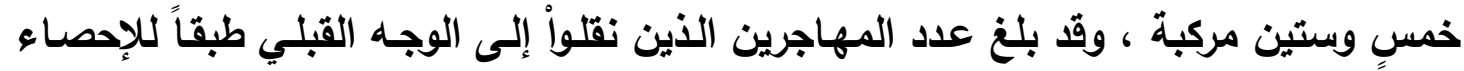

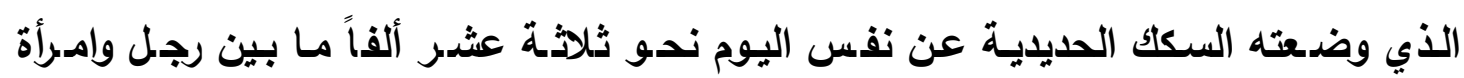

وطفل (')

ومهما يكن من أمرٍ فقد أمكتنا بالرجوع إلى بيانات مكتب الضابط القضائي بمحطة العاصمة أن نحصل على بيانات أكثر دقة وأثثد تفصيلاً بخصوص أعداد المهاجرين الذين الذين

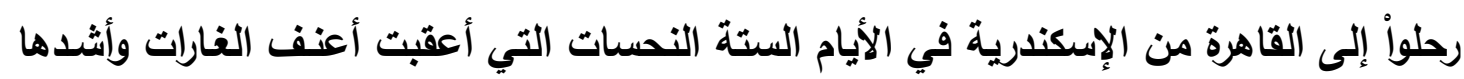

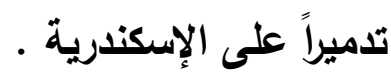

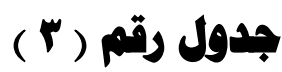

أعداد الفارين من الإسكندرية إلى القاهرة ويـلاد الوجه القبلي في الفترة من ^ يونيو

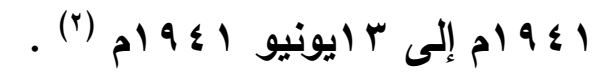

\begin{tabular}{|c|c|c|c|}
\hline سافر إلى الصعيد & تخلف بالقاهزة & وصل للقاهرة & المـدة \\
\hline 7791 & $?$ & $?$ & 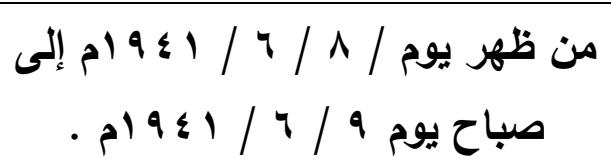 \\
\hline $1.7 \leq 7$ & Trav & $179 \leq r$ & يوم 9 / צ / إ 9 ام \\
\hline |rrvi & $\leqslant 0 \leqslant 1$ & IVqIY & 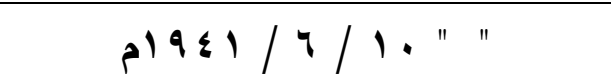 \\
\hline $1.9 \mathrm{VV}$ & $909 \mathrm{~V}$ & IVOVE & " " "11951/7/11 \\
\hline$T \leqslant V Y$ & 7.81 & Iros r & " " " " \\
\hline \&rro & D. & Vovo & " " سו / ד / إم \\
\hline orrar & rY104 & VYO $E V$ & المجموع \\
\hline
\end{tabular}

وضح إذن أن تقديرات رئيس الوزراء حسين سري لأعداد الفارين من جحيم الغارات

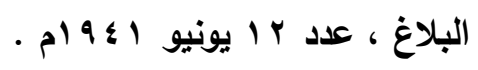

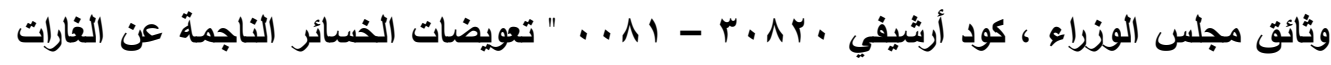
الجوية " مذكرة عن الإجراءات التي أعلتها وزارة الصحة العمومية لإسعاف المصابين وحماية صحة 
على الإسكندرية - مـا بين ثلاثين إلى خمسة وثُلاثين ألفا - وكذلك تقديرات وزيره للأثشغال

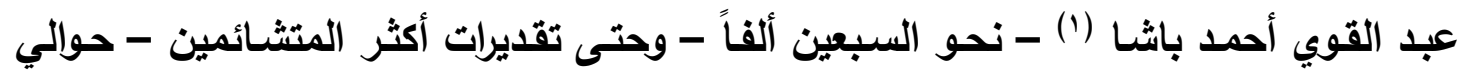
الثمانين ألفاً - كانت أبعد بكثير عن الحقيقة ، فإذا كان من وصل من هؤلاء إلى القاهرة

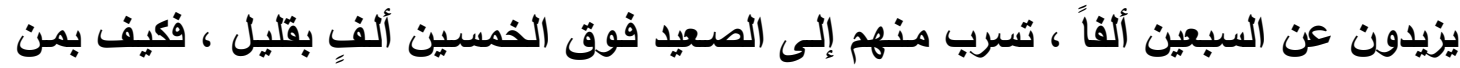

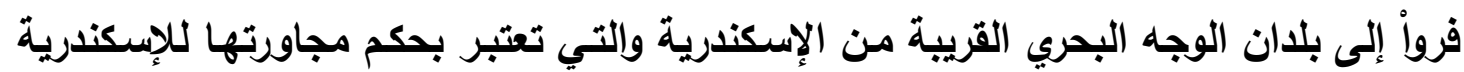

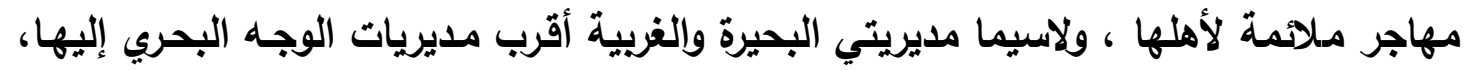

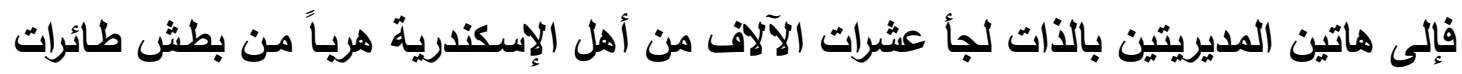

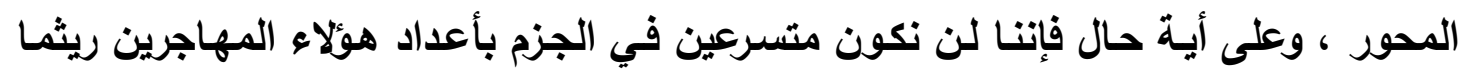

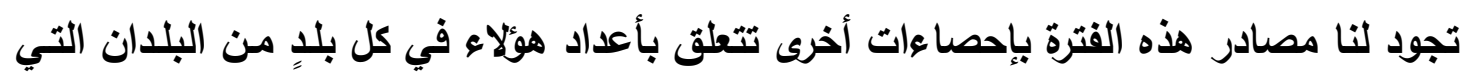

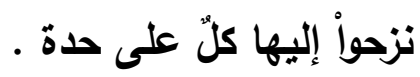

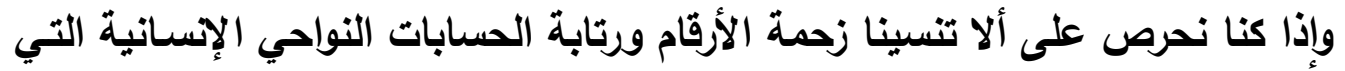

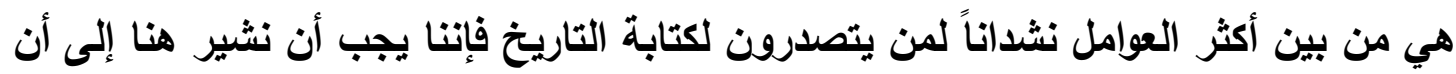

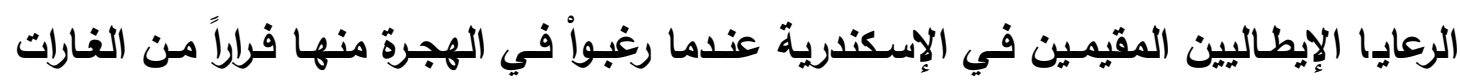

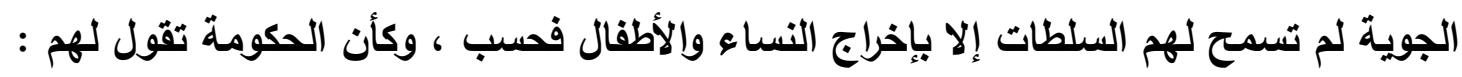

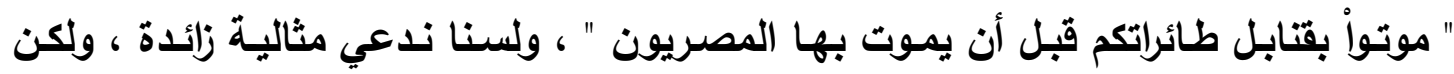

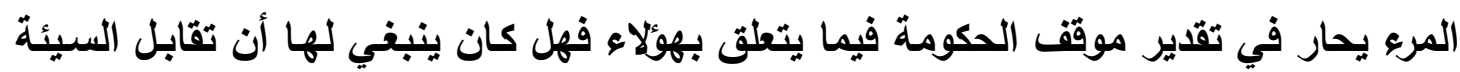

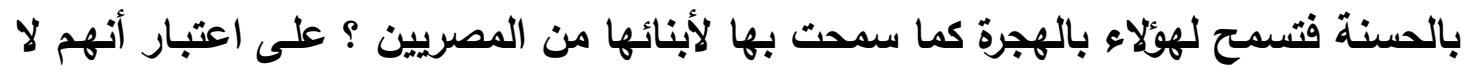

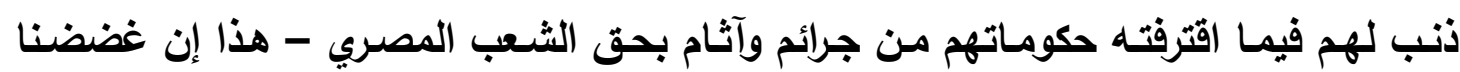
الطرف عن موقف مصر المتخاذل إزاء المحور والمتعاون مع الحليفة بريطانيا ، ولو أن إغفال

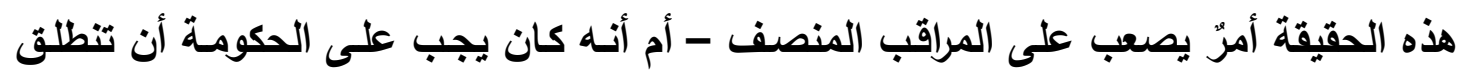

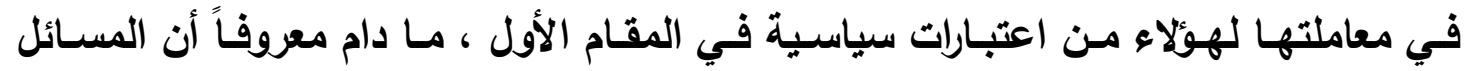

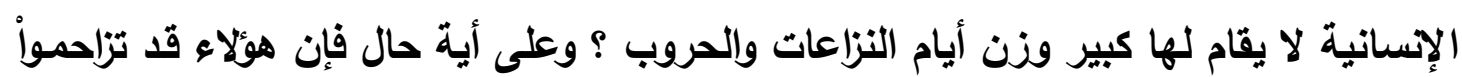

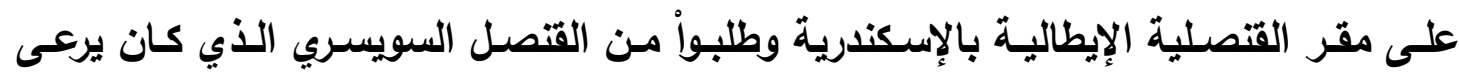

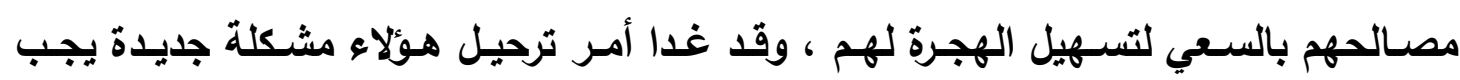

وُلْد عبد القوي أحمد باثنا بمديرية المنوفية ، درس الهندسة ويرع فيها ، واشتهر بدراساته عن

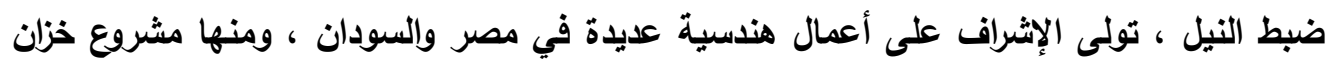

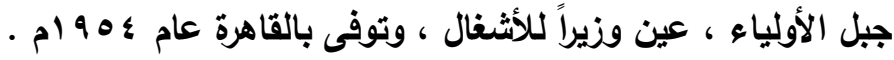

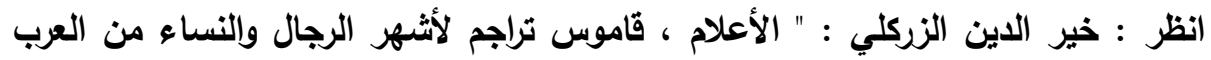

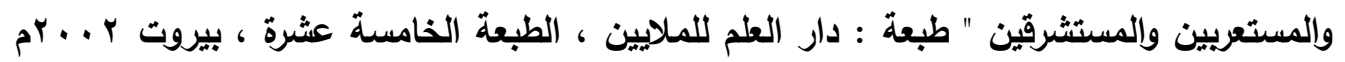


الاهتمام بها ومعالجتها من جانب السلطات (1)

على أن ممـا يلفت الاتبـاه في أيسام العسر هذه هو مناشـدة وزيـر الأثـغال لرجـال

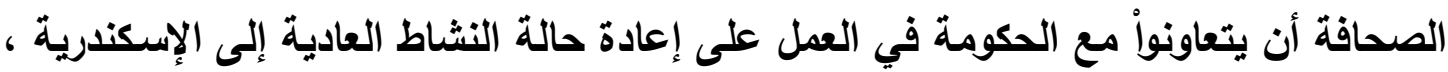

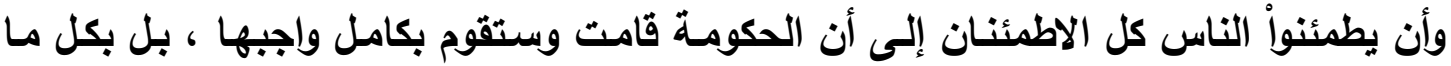

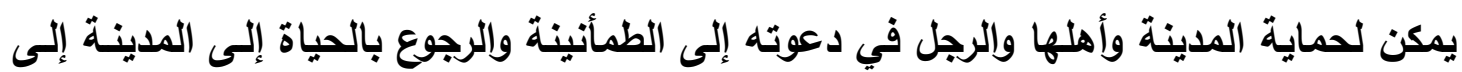

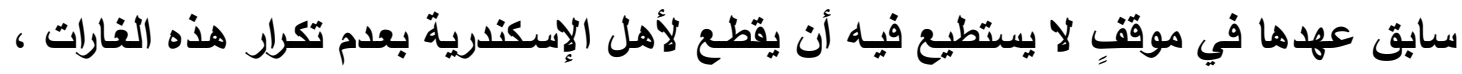

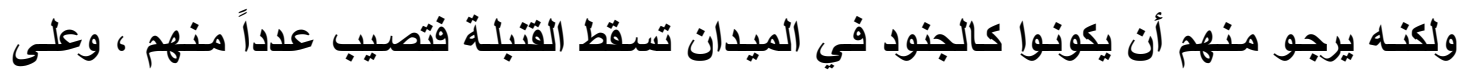
الباقين أن يصدواً بل أن يتقدمواُ .

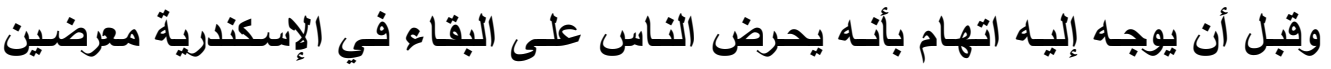

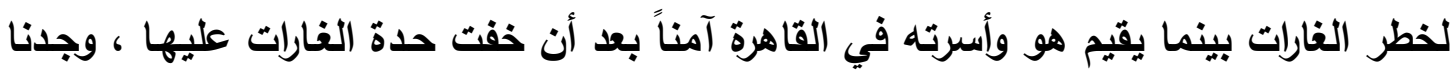

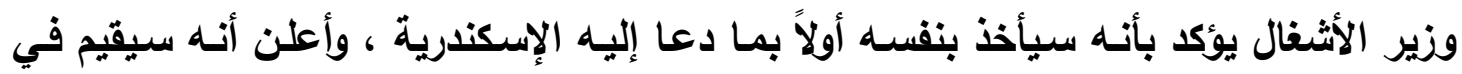

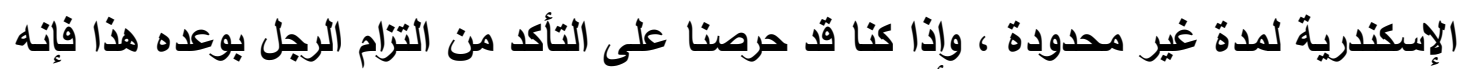

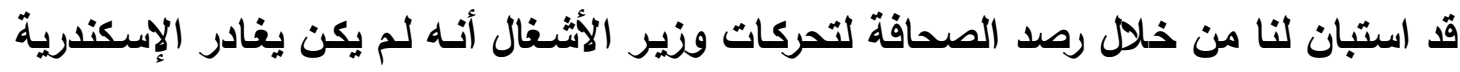

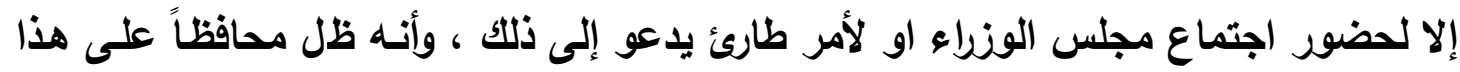

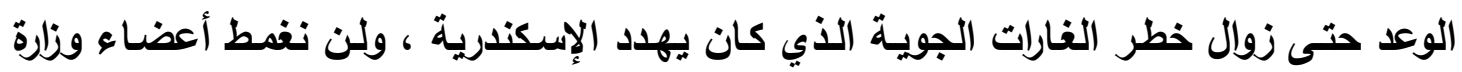

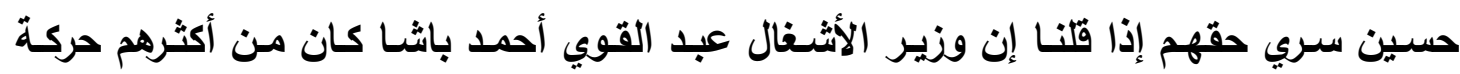

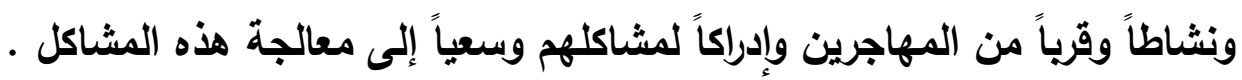

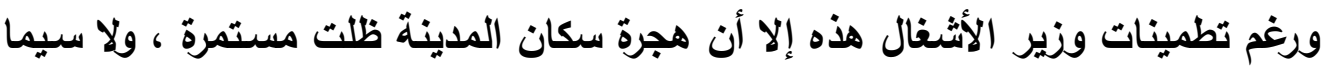

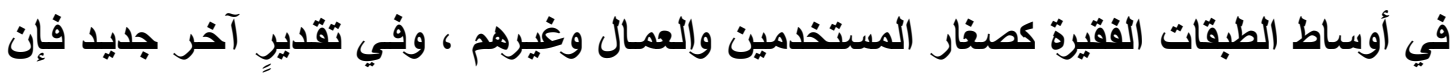

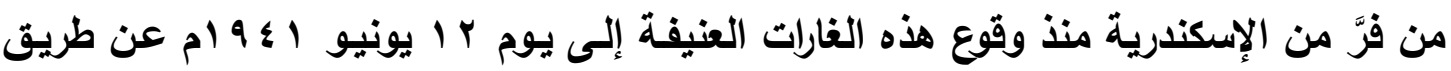

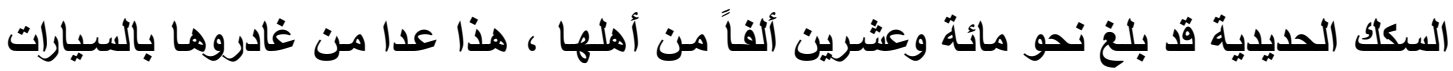

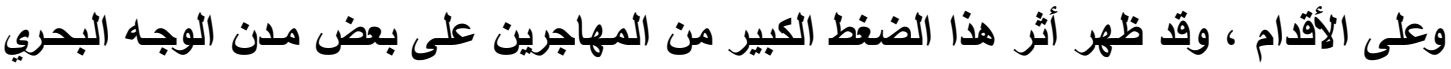

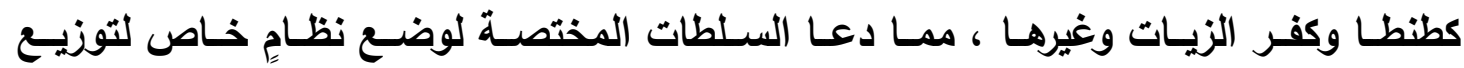

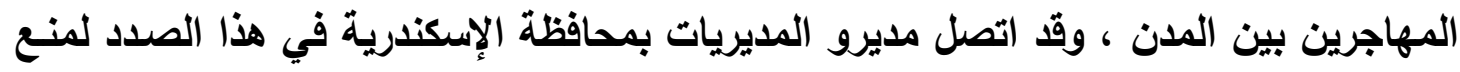

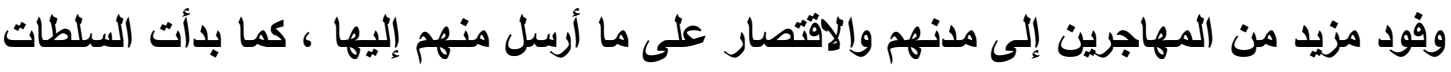

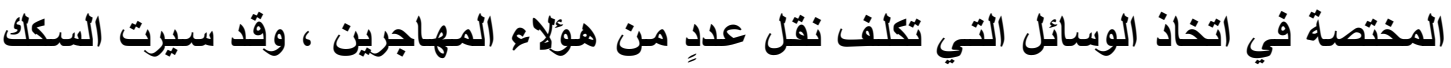

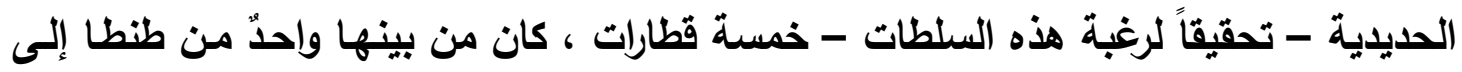

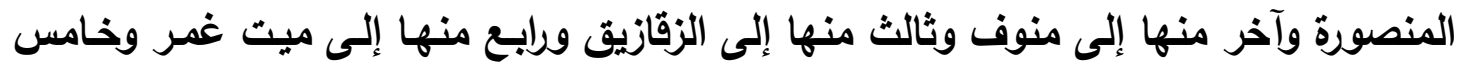


من كفر الزيات إلى منوف (1)

سمح انقطاع الغارات الجويـة لمدة خمسة أيسام للجميع بأن يلتقط الأففاس ، فكانت

فرصة استغلها حسين سري رئيس الوزراء في أن يوجه شكراً لرجال مصلحة السكتك الحديدية تلقاء الجهد العظيم الذي بذلوه خلال القترات العصيبة من هجرة أهل الإسكندرية ، وقابل مدير المصلحة علي طراف باشـا شكر رئيس الوزراء بامتنـان زائد ، كما أن عدداً كبيراً من عمال الإسكندرية آثز البقاء فيها وعدم الهجرة مما كان له أثره في تمكين الكثيرين من أهلها من الحصول على حاجاتهم المعيثية .

ويعد أن هدأت الأحوال كان على الحكومة أن تخضع لمساعلة ممثلي الأمة ، فخصص مجلس النـواب جلسـة لمناقثـة بيـان الحكومسة الخـاص بالغـارات الجويـة التـي وقعت على التى

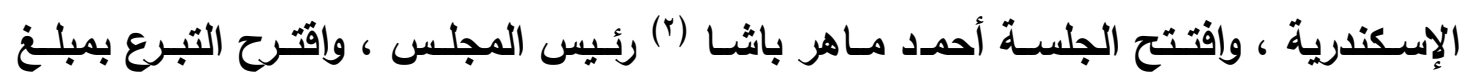

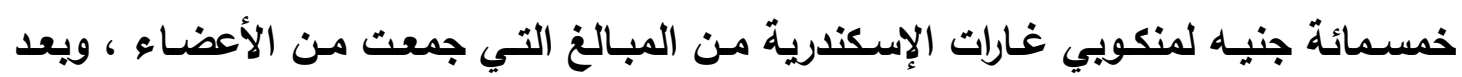
المواققة بـأث المناقشـات فاتتـد النائب حسن الجداوي السماح بـالهجرة من الإسكندرية من غير ترتيب أدى إلى خللٍ في حركة المدينة ، وطلب أن تكون الهجرة مقصورة على الأطفال والنساء والعجزة .

وتكلم العضو أحمد شاهين في أثز الشائعات على زيادة حركة الهجرة ، وأن المهاجرين وقعوا أسرى لهذه الشـائعات والمبالغات والخيالات ، وطالب الصحافة بتحري الاقة ، وطالب الحكومة كذلك بالشفافية في البيانات الرسمية . كما طلب العضو أحمد أبو العلا أن توفر الحكومة للأهلين ما يلزمهم من ملجأ آمن ، ونبه إلى اتدساس عناصر من الاخلاء بين المهاجرين لكي يستفيدواً من مساعدات الحكومسة لهم ، كما أنهم كانواً يستجدون الناس في الطرقات بدعوى أنهم مهاجرين تقطعت بهم السبل .

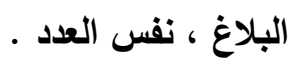

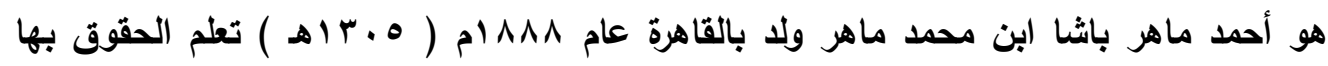
ويفرنسا ، اشترك في الحركة القومية مع سعد زغلول ، وإنفصل عن الوفد بعد وفاة سعد وألف حزباً

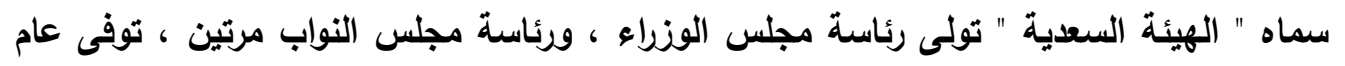

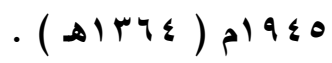

له ترجمة في : زكي محمد مجاهد : " الأعلام الثرقية في المائة الرابعة عشر الهجرية "

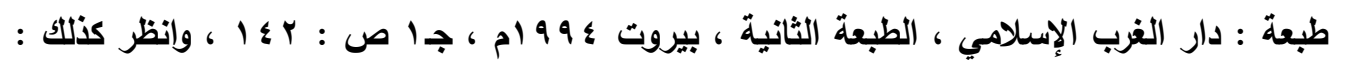

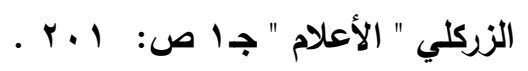




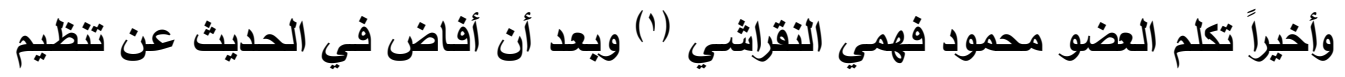

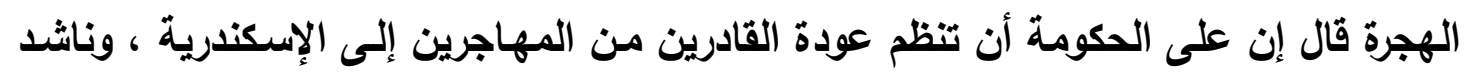

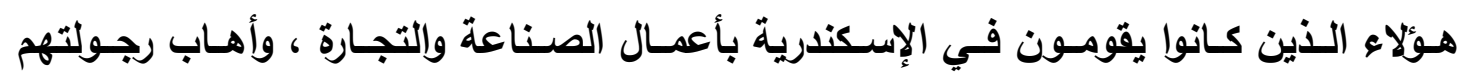

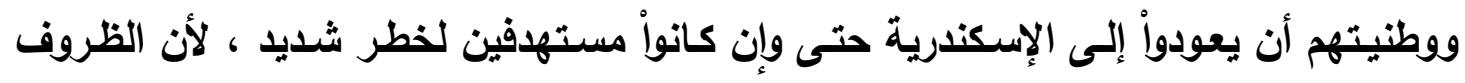

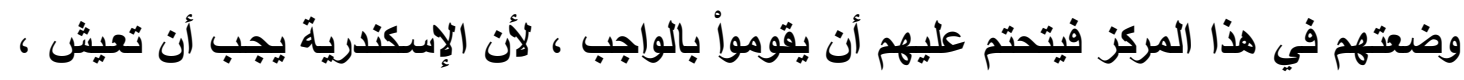

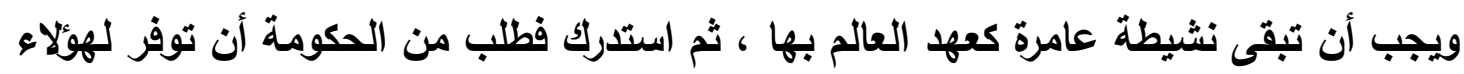

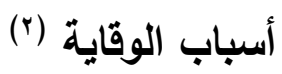

وأول ما يلاحظ على مناقثات ممثلي الثعب أنهم اهتمواُ بالعوامل المحفزة على الهجرة

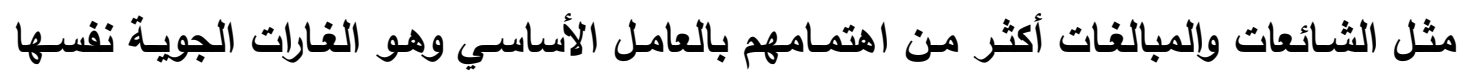

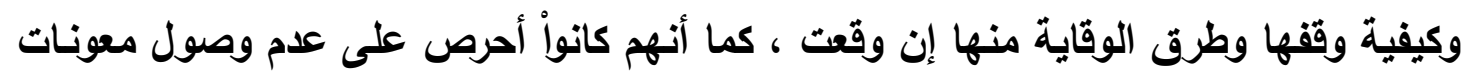

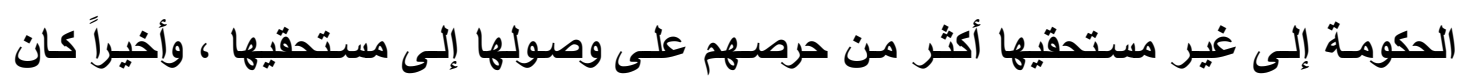

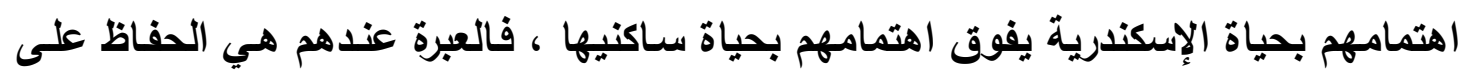

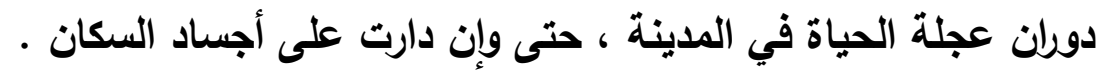

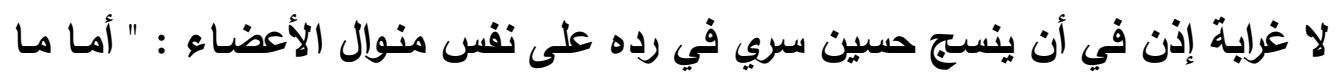
يثار بشأن تقصير الحكومة في تيسير الأماكن للأهلين الراحلين فإنهله على أثر الغارة الأخيرة

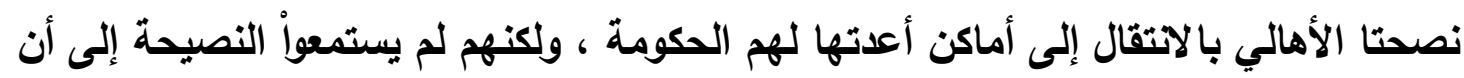

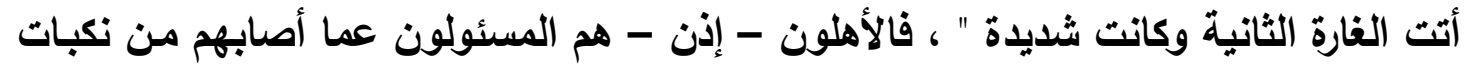

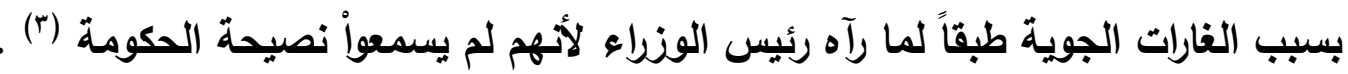

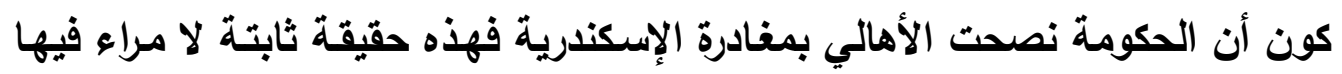

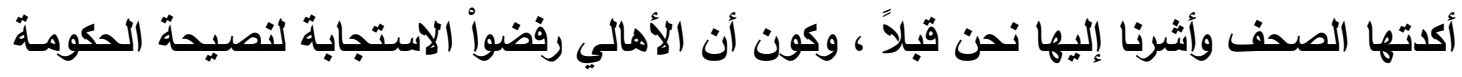

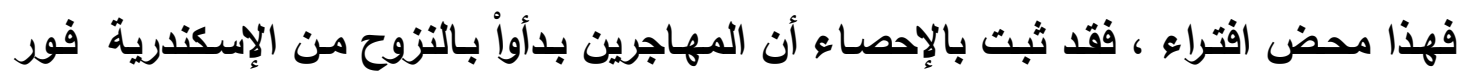

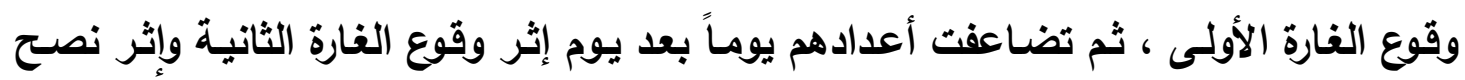

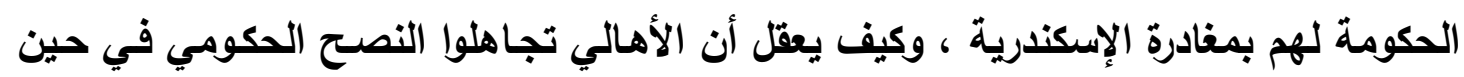

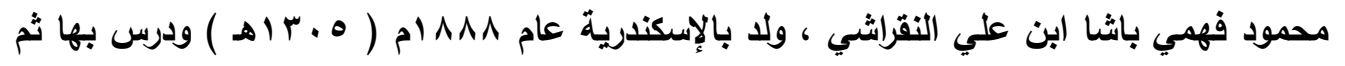

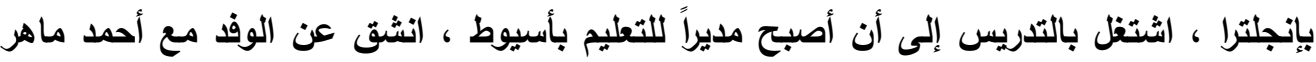

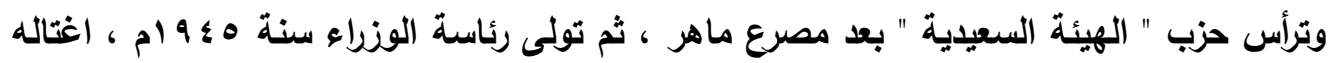

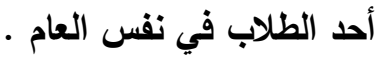

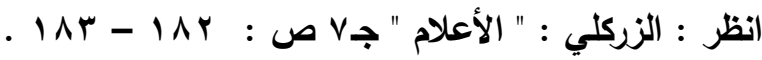

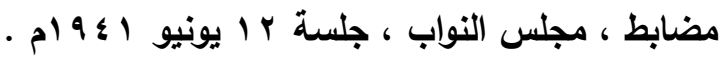

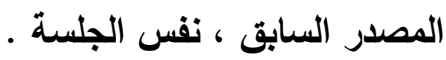


أن مئات الآلاف منهم هجرواً المدينة ثم انبثواْ في جميع أرجاء القطر المصري كالجراد المنتثر

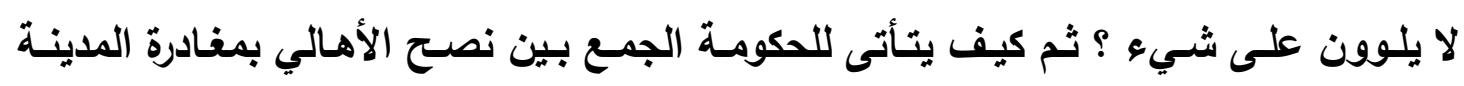

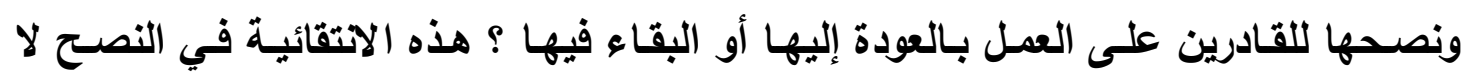
تستقيم مع المنطق السليم •

على أية حال فإن وزير الأشغال عبد القوي أحمد باشـا كان أكثر واقعية من رئيسـه ،

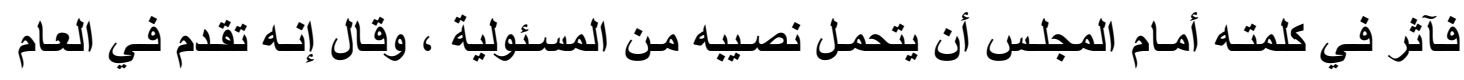

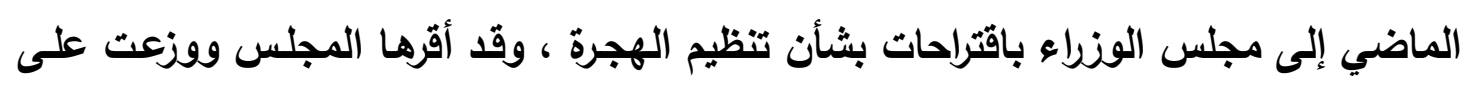

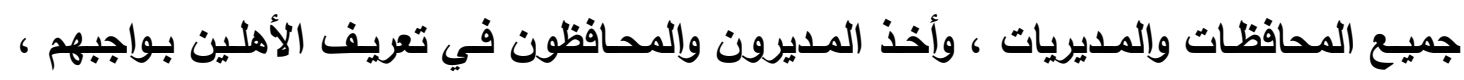

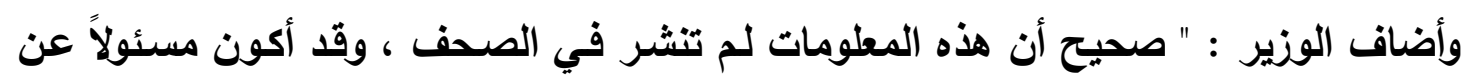

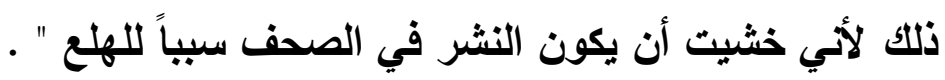

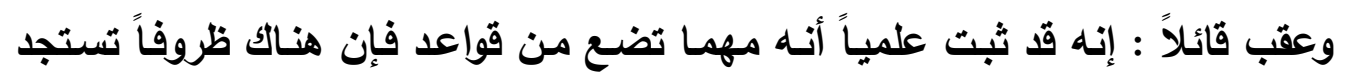

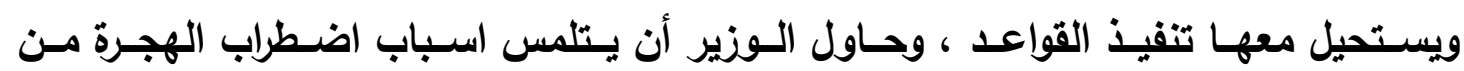

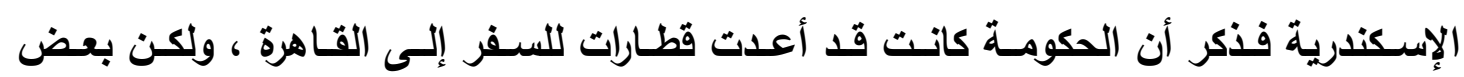

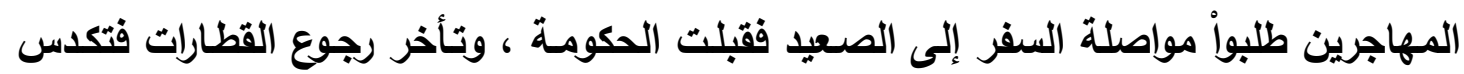

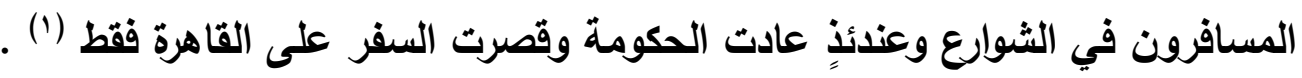

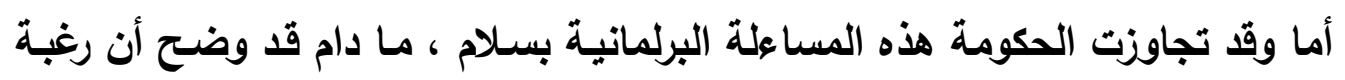

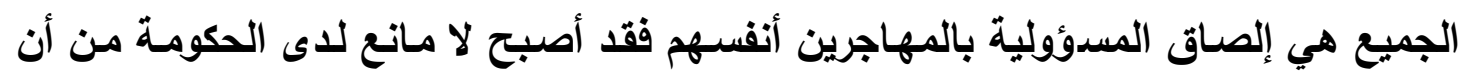

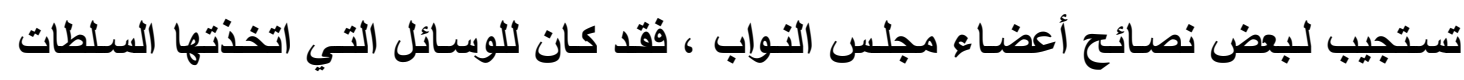

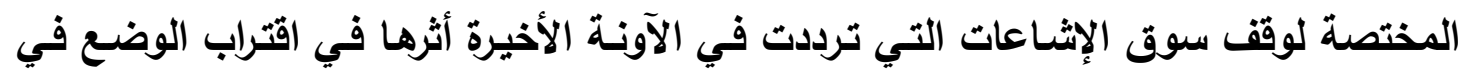

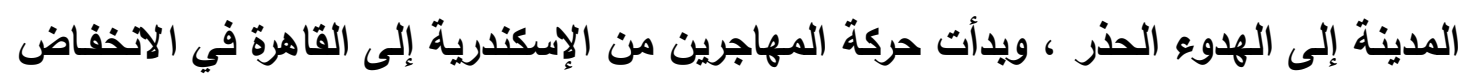

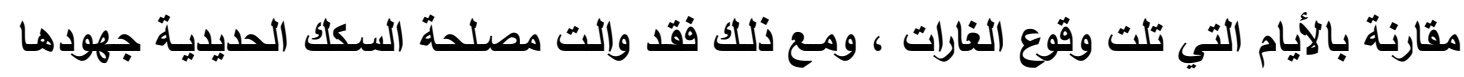
في سبيل توفير القطارات الخاصة ، وكان لوقف سير القطارات على بعض الغارت الخطوط الفرعية أثره في زيادة عدد القطارات التي تخصصها لنقل المهاجرين بين الإسكندرية والقاهرة ، فقد بلغ الغطيل

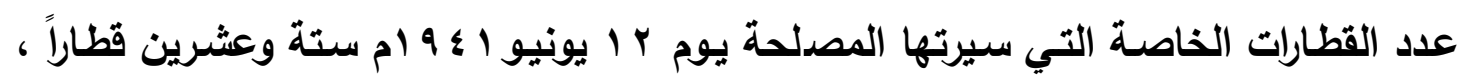

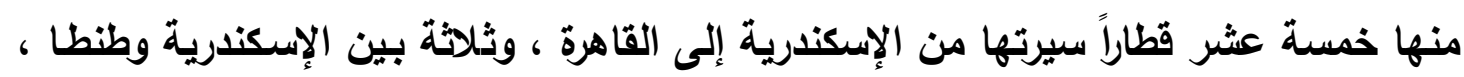

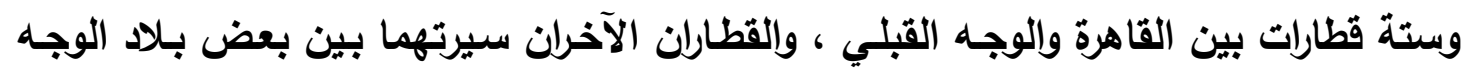

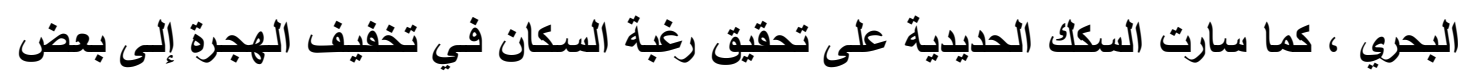

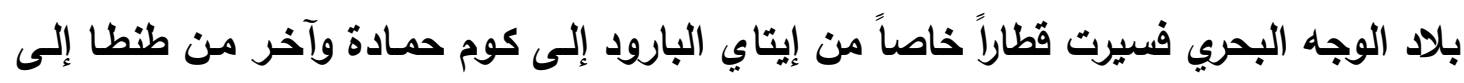


كان المظنون بعد أن انقضت ستة أيسام كاملـة بلا غارة ويعد تطمينات الحكومـة ويعد القضاء على سوق الإثاعات أن تهدأ بذلك أعصاب الكثيرين ، ولكن كان الناس في اضطراب

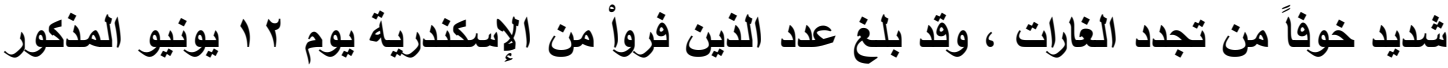

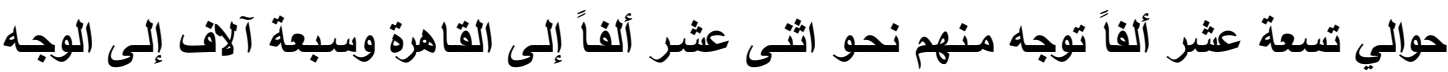

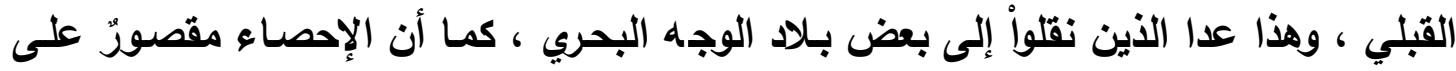

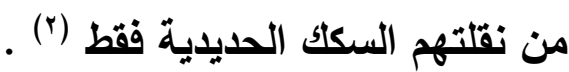

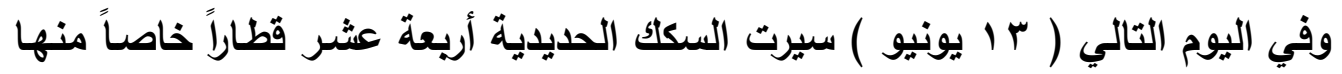

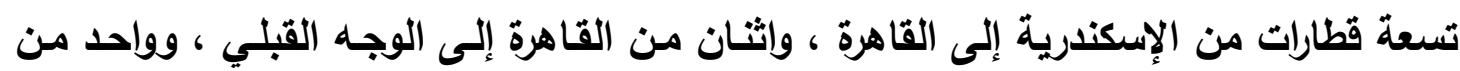

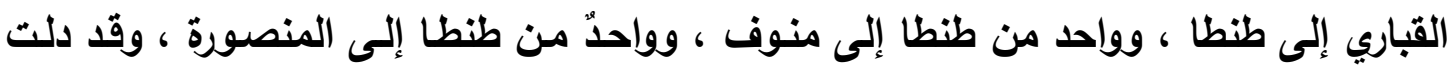

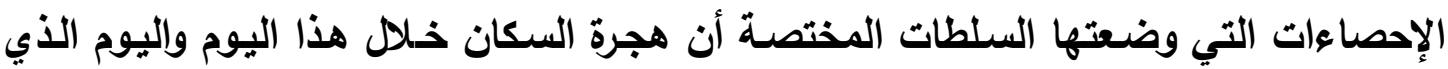

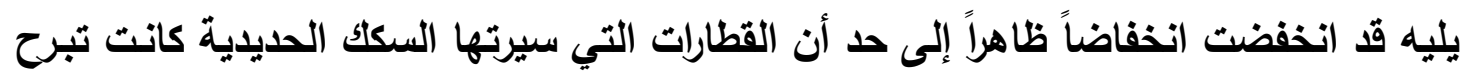
المدينة وليس بها سوى عددٌ يسيرٌ من المهاجرين ، وقد رأت السلطات أن الحالة أصبحت لا لائل

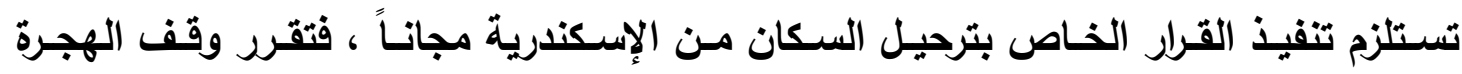

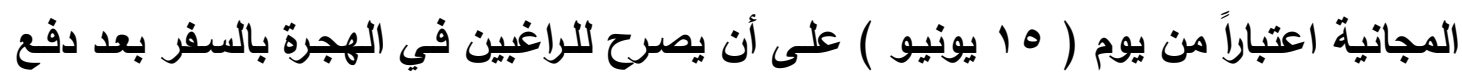

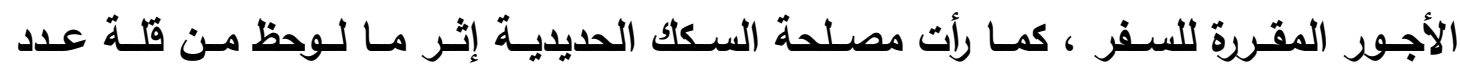
المهاجرين وتنفيذ القرار الخـاص بوقف الهجرة المجانيـة عدم الحاجـة إلى تسيير القطارات الخاصة التي اعتادت تسييرها من الإسكندرية والقاهرة، والاقتصار على القطارات العادية (").

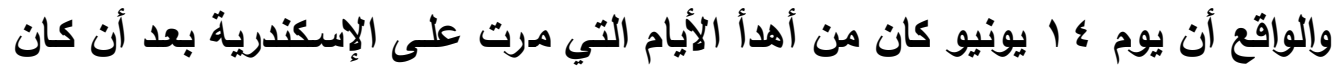

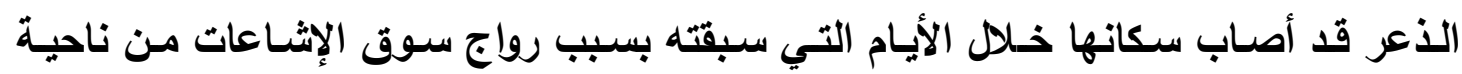

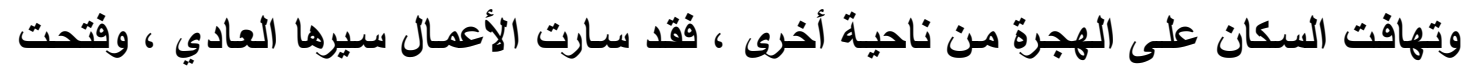

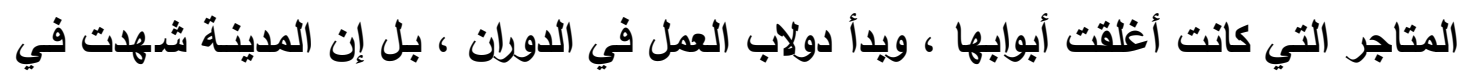

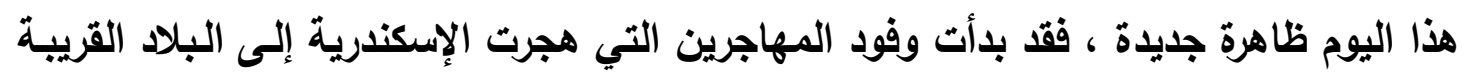

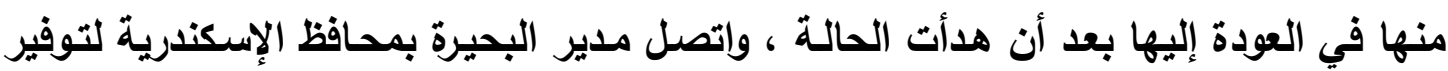

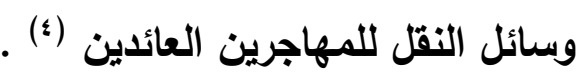

$$
\begin{aligned}
& \text { البلاغ ، عدد سا } 1 \text { يونيو 19 أم . }
\end{aligned}
$$

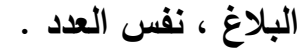

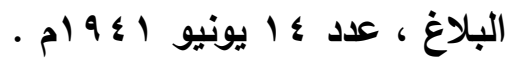

$$
\begin{aligned}
& \text { البلاغ ، نفس العدد . }
\end{aligned}
$$


كان من الطبيعي أن تقل حركة التداول في سوق الأولق المالية في الإسكندرية خـلال

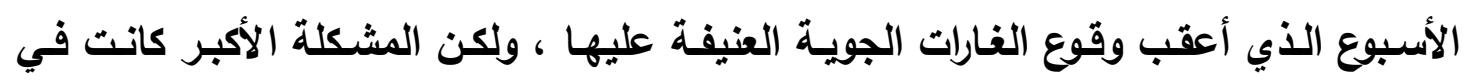

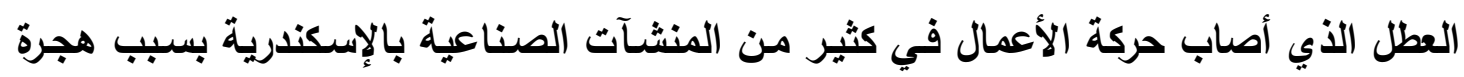

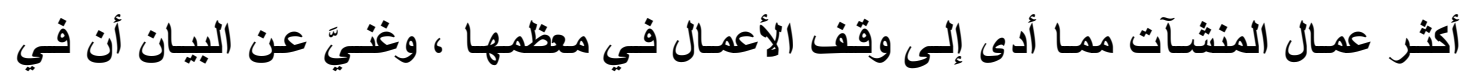

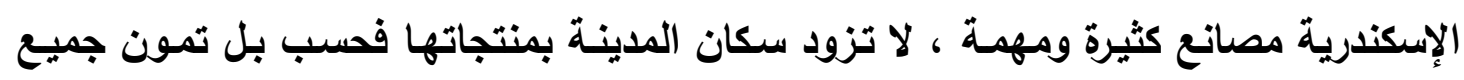

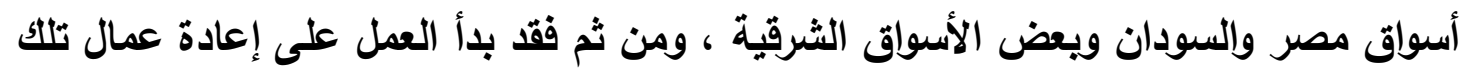

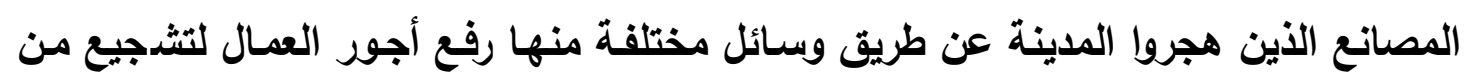

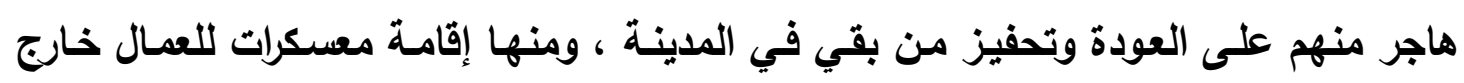

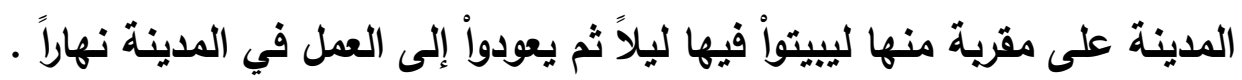

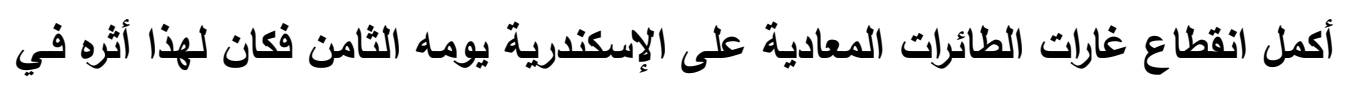

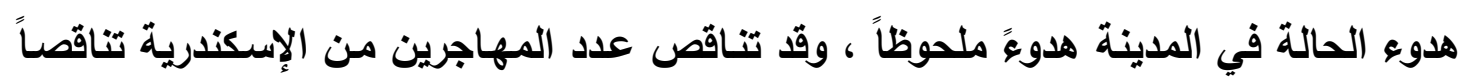

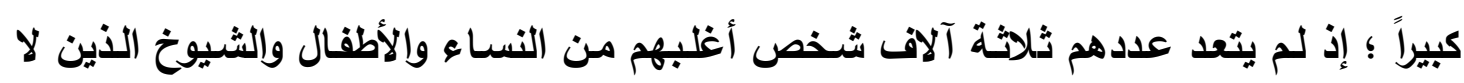

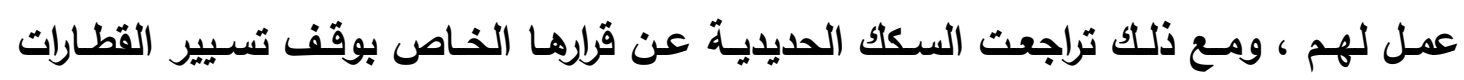

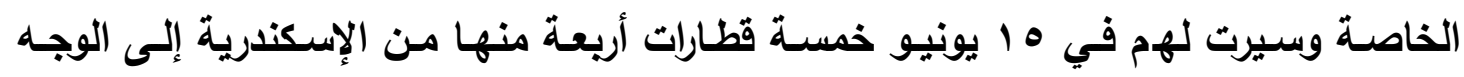

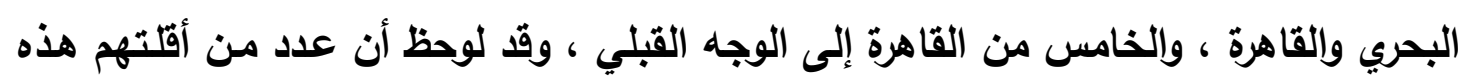

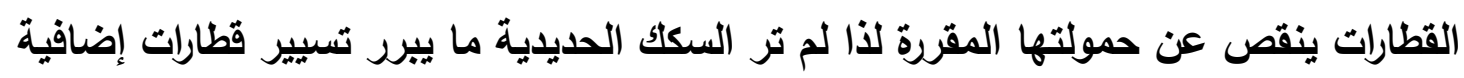

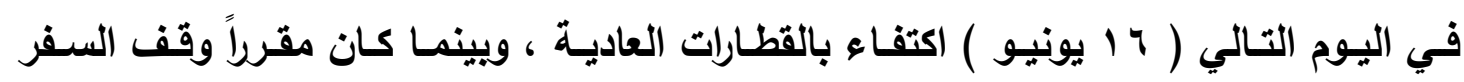
المجاني اعتباراً من منتصف ليلة 10 يونيو فقد رأت مصلحة السكك الحديدية مد هذا القرار لمدة أربعة وعشرين ساعة إضافية على أن يُقْصر امتياز السفر المجاني على النساء النساء والأطفال

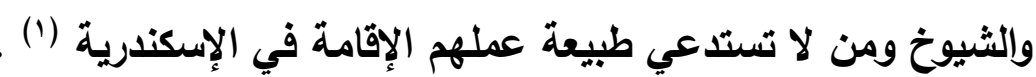

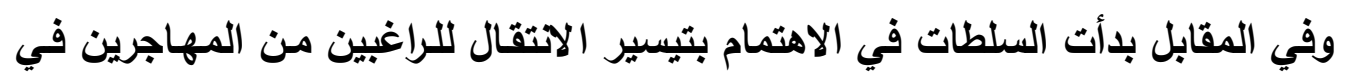

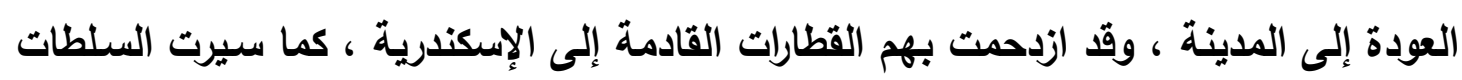

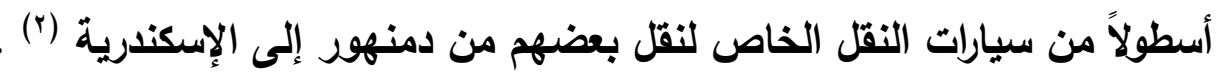

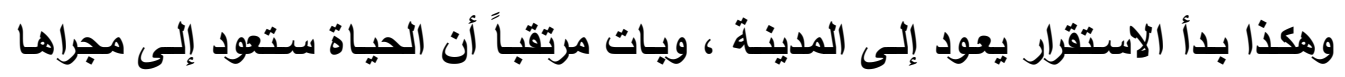

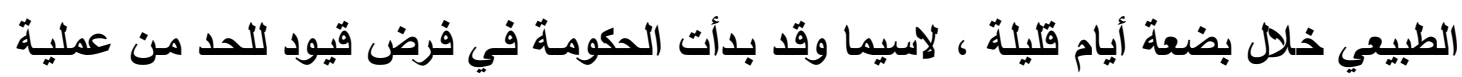

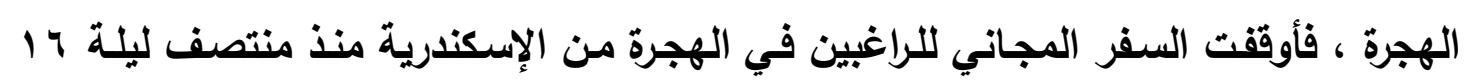

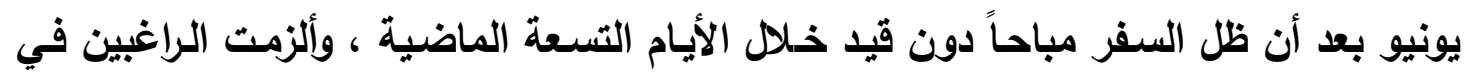

$$
\begin{aligned}
& \text { البلاغ ، عدد } 17 \text { يونيو إ؛ } 9 \text { ام . } \\
& \text { البلاغ ، نفس العدد . علد }
\end{aligned}
$$


السفر من هؤلاء بتقديم طلب على أنموذج معدٍ لذلك شرط أن يكون الطالب من رقيقي الحال ،

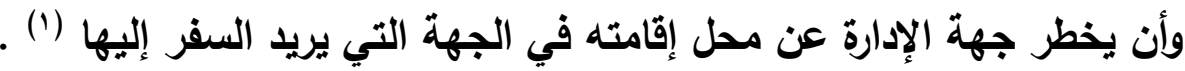
وقد أمكن لمصلحة السكك الحديدية - بعد هدوء أزمة الهجرة من الإسكندرية - أن تقدم لنا

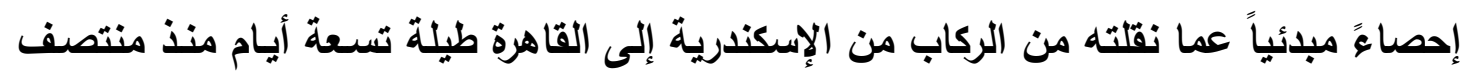

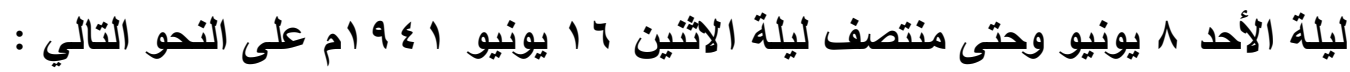

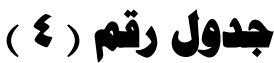

المنقولون بواسطة السكك الحديدية من الإسكندرية إلى القاهرة في الفترة من ^ 1 إلى

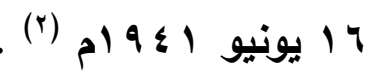

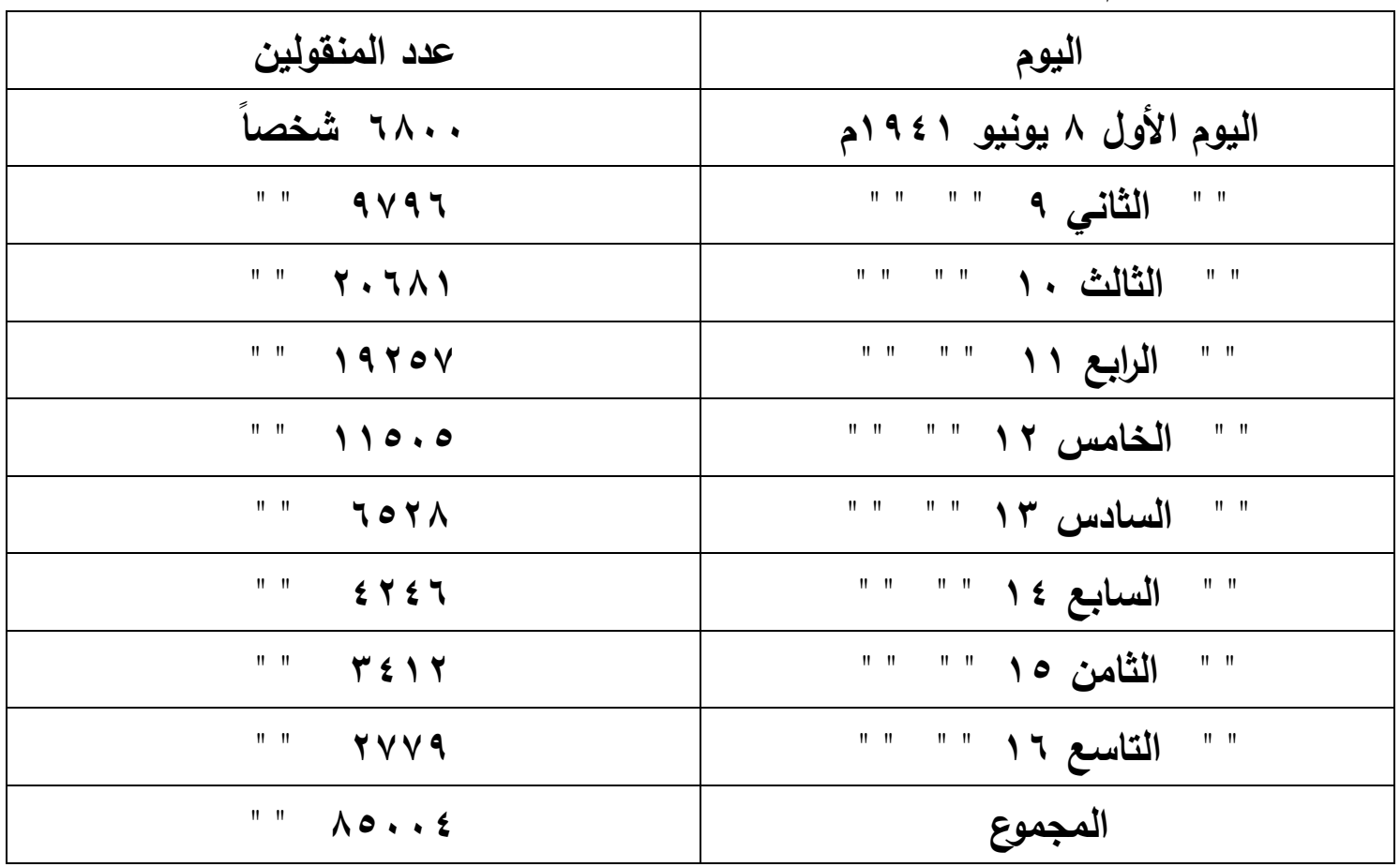

كمـا نقلت السكك الحديديـة إلى الوجـه القبلـي خـلال الأيـام التسعة المـكورة حوالي

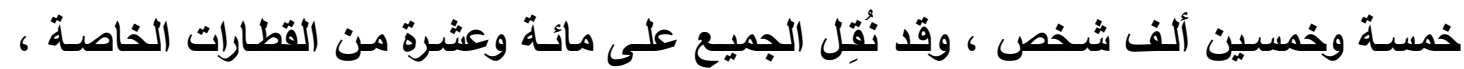

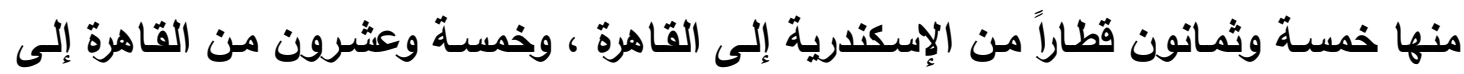

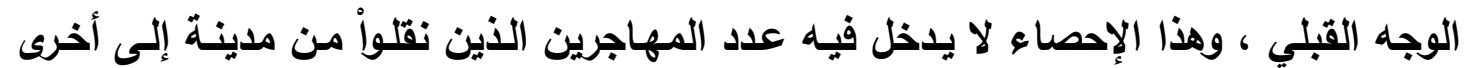

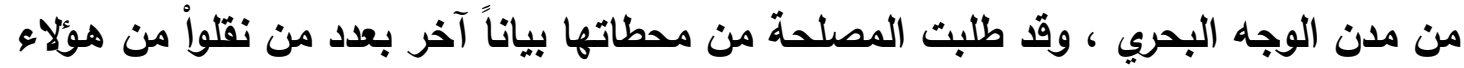

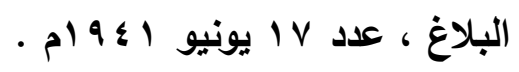

وضعنا هذا الجدول بالاستعانة بالأرقام التي أوردتها صحيفة " البلاغ " في عددها الصادر

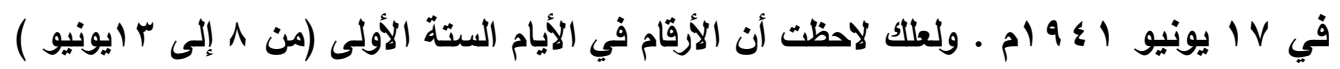

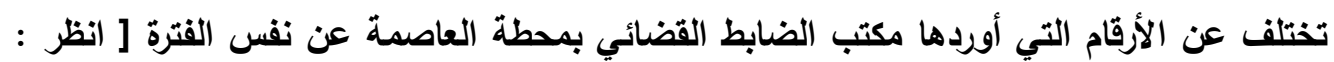
جدول رقم ץ ] ومع ذلك فالإجمالي العام في كلا الإحصائين يكاد يكون متقارياً. 
، كما أن هناك طوائف من المهاجرين نزحواْ بطرقٍ أخرى غير السكك الديدية وتسريواً إلى

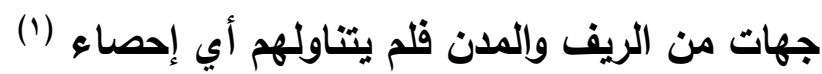

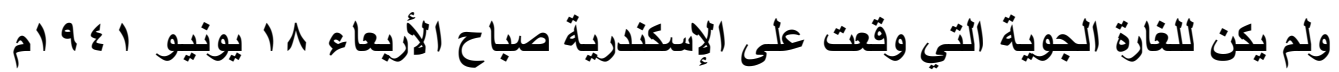

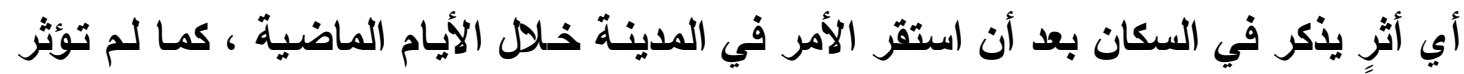

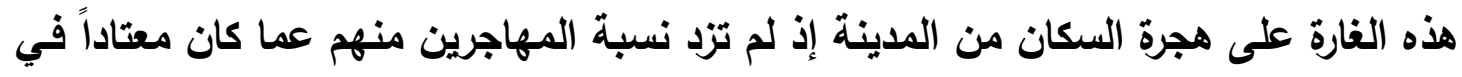

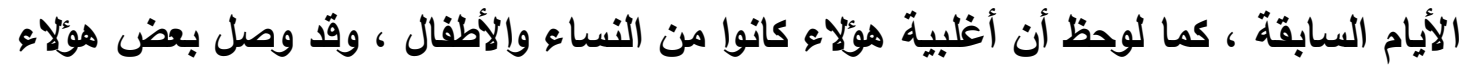

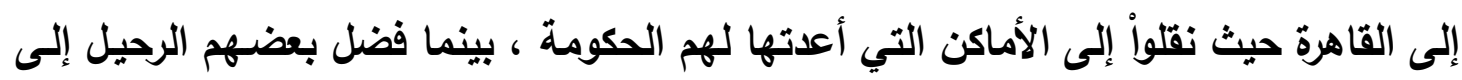
الوجه القبلي حيث صرفت لهم تذاكر سفر مجانية (ץ) .

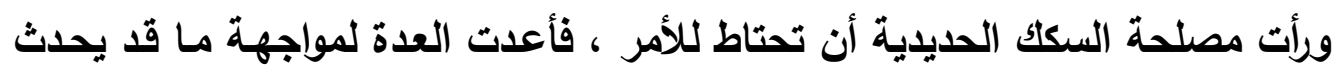

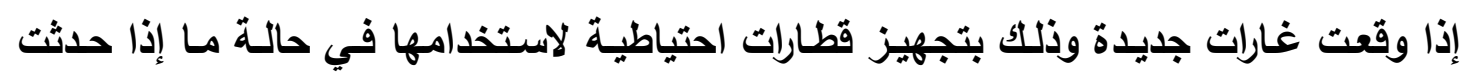

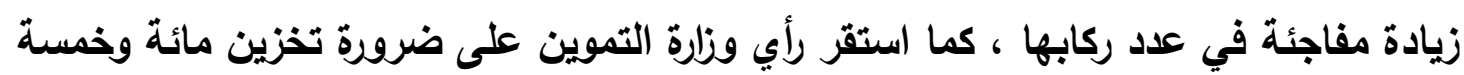

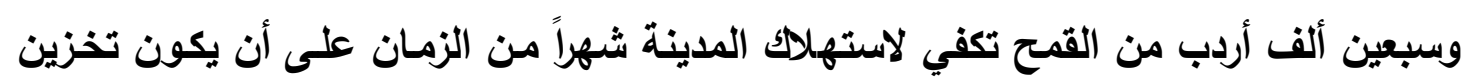

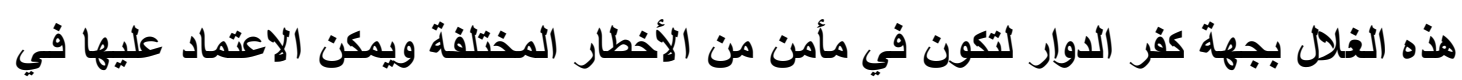

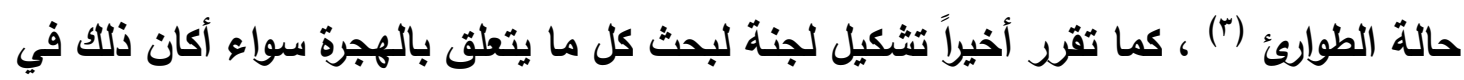

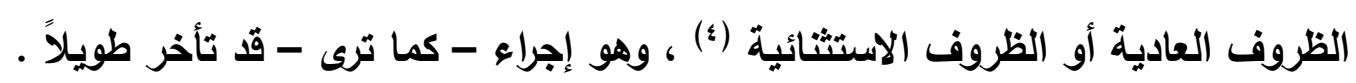

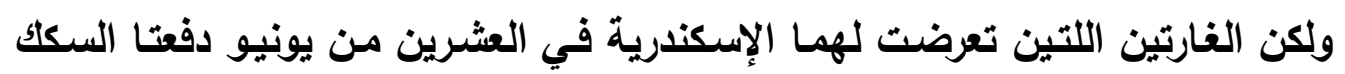

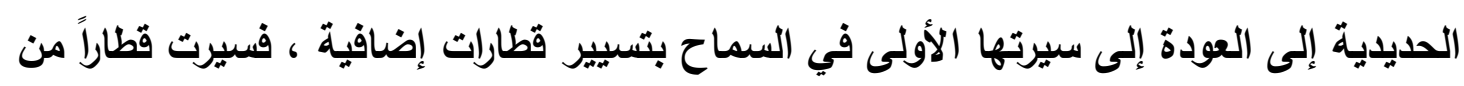

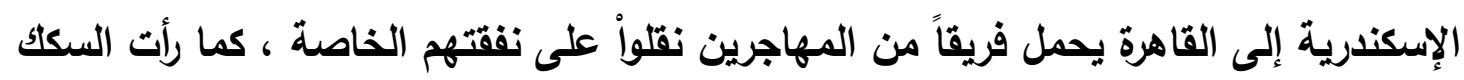

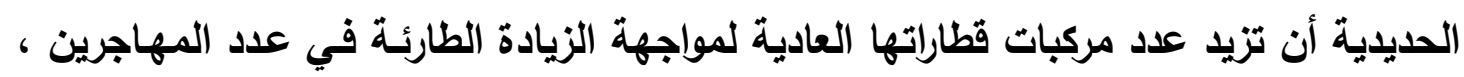

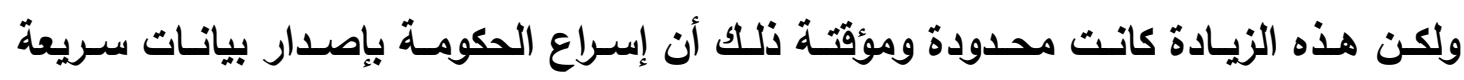

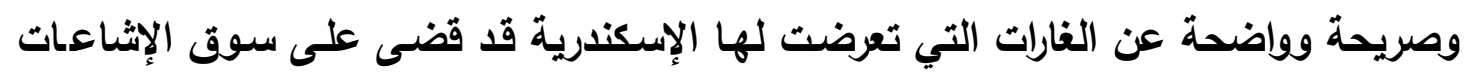
التي تروج عادة إثر كل غارة تقع على المدينة ويبالغ المرجفون كثيراً في نتائجها (•) .

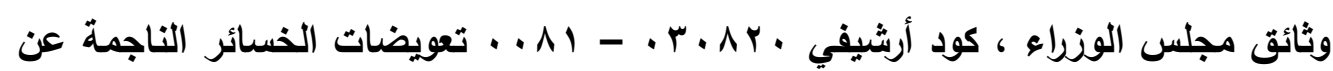

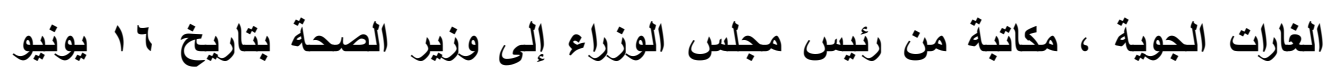

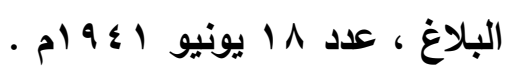

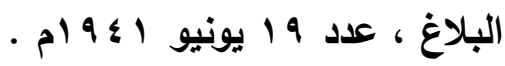

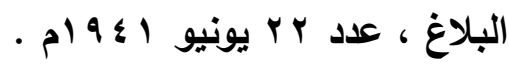


وعلى أية حال فإن انكسار حدة موجة الهجرة الجماعية من الإسكندرية باتجاه القاهرة

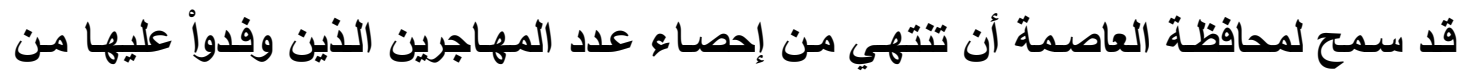

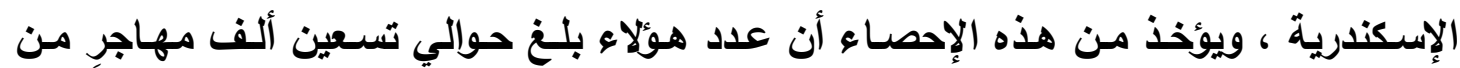

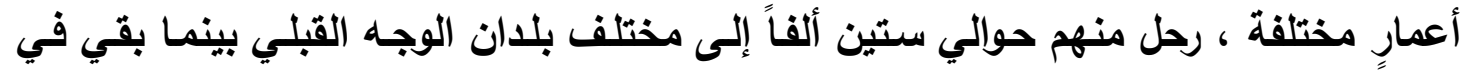
العاصمة حوالي ثلاثين ألفاً (1) وتمضي الأيام والمشاهد مكرورة ففي صباح يوم الاثنين بَ بونيو تلتعرض الإسكندرية

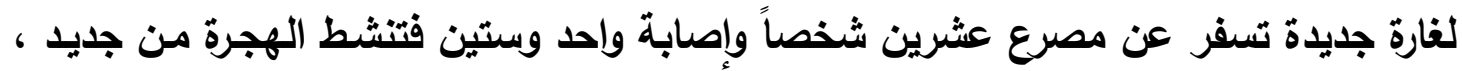
وتسير السكك الحديدية قطاراً خاصاً يحمل عدداً من المهاجرين إلى القاهرة وتضاعف مركف مركباتها

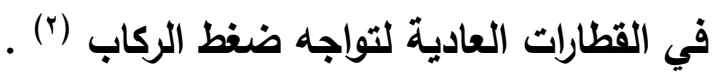

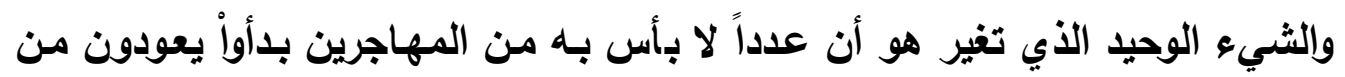
مهاجرهم إلى الإسكندرية مرة أخرى وذلك بالنظر إلى الظروف المعيثية القاسية التي عانوها

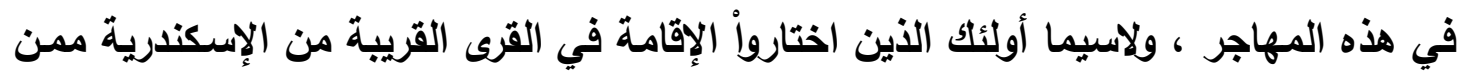

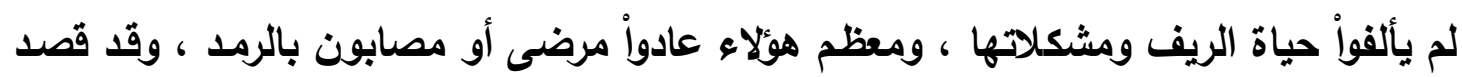

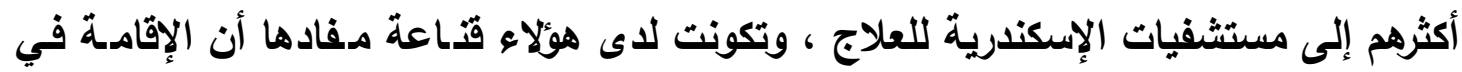

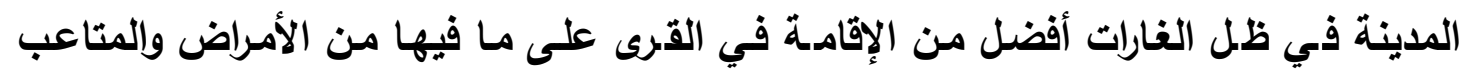
الجمة (ن)

والواقع أن مأساة المهاجرين كانت مزدوجة ، فهم ما بين معاناتهم التشرد ويين قلقهم

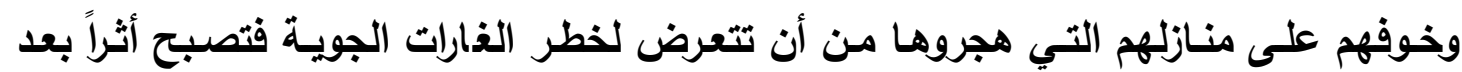

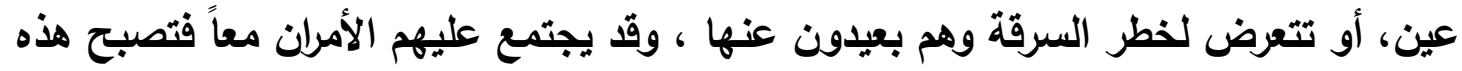

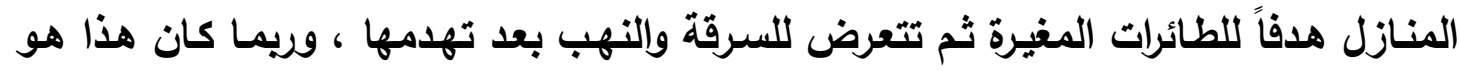

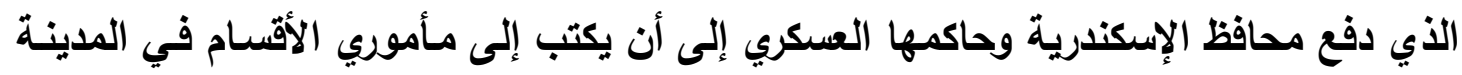

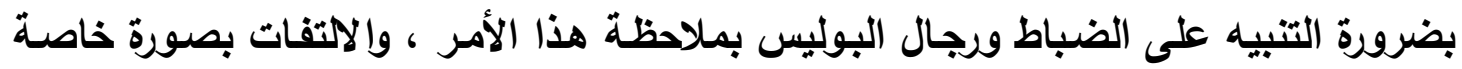
إلى من يجوسون خلا الديار ويحومون حول أنقاض المنازل المتهدمة ممن ليسواً من أهالي

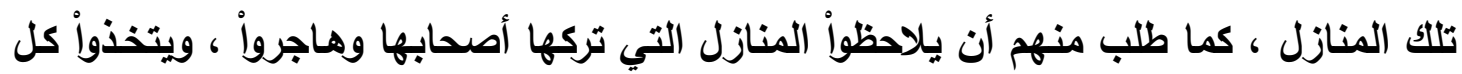

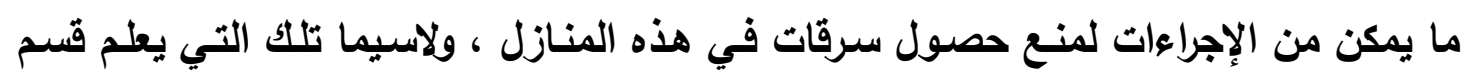

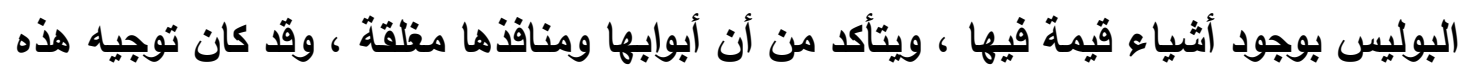

$$
\begin{aligned}
& \text { البلاغ ، نفس العدد . }
\end{aligned}
$$

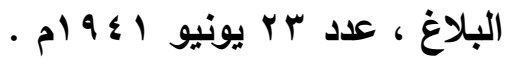

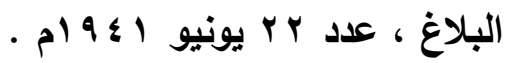


التنبيهات إلى رجال البوليس على أثر وصول شكاوى عديدة إلى المحافظة من المهاجرين (1) هذه الظروف العصيبة التي قاسى منها المهاجرون كانت وراء ذلك السيل المنهمر من

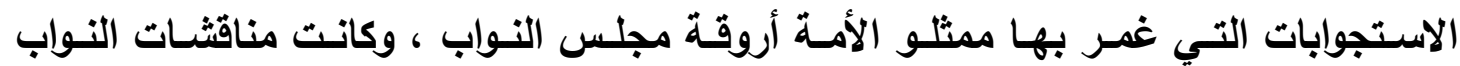

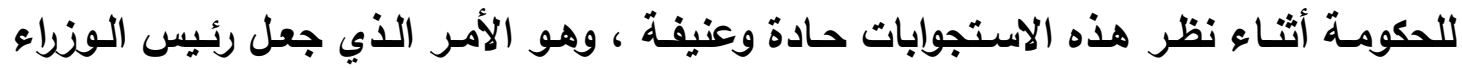

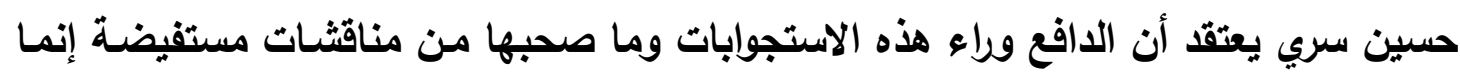

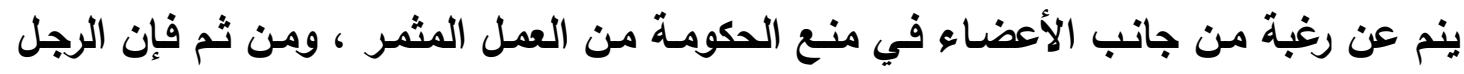

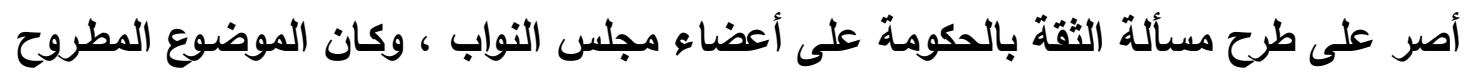

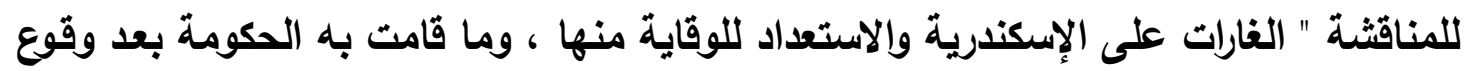

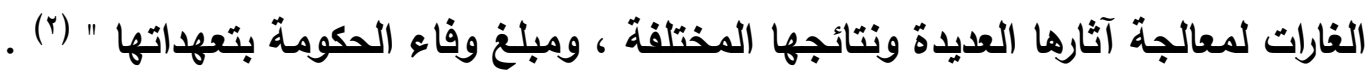

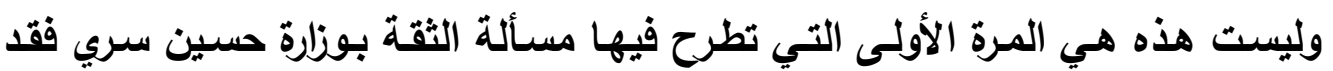

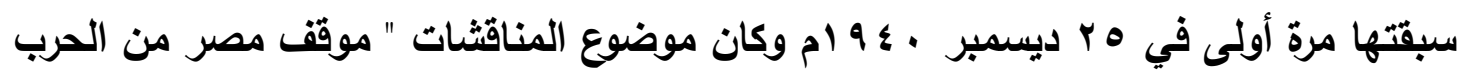

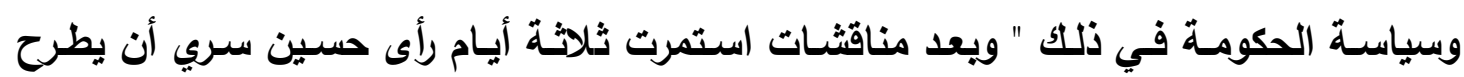

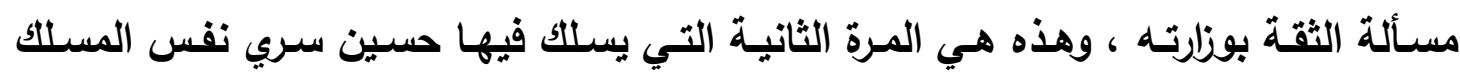

ويطلب من النواب التصويت على الوزارة (") .

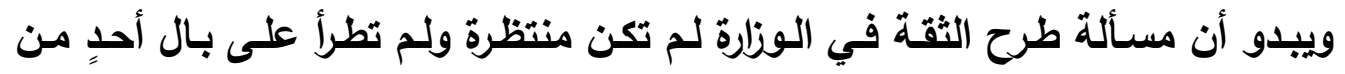

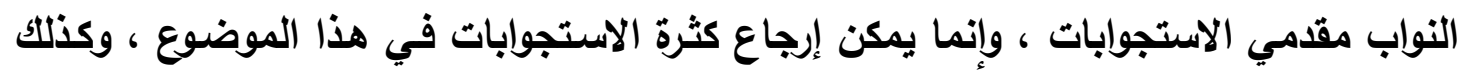

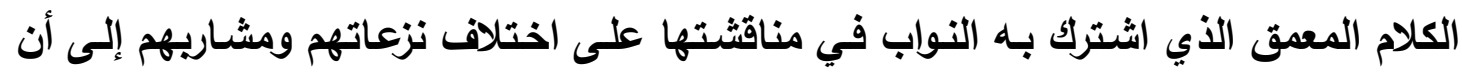

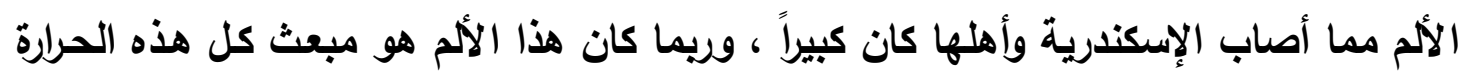

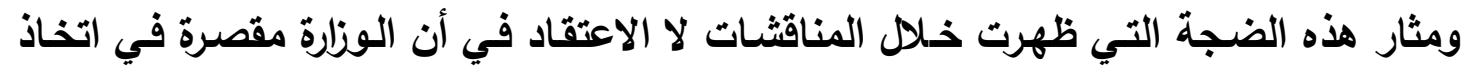

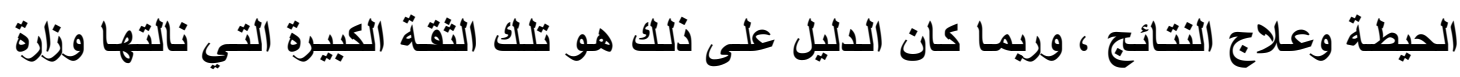

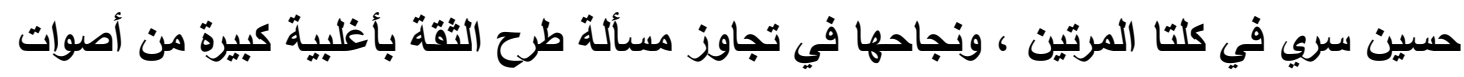

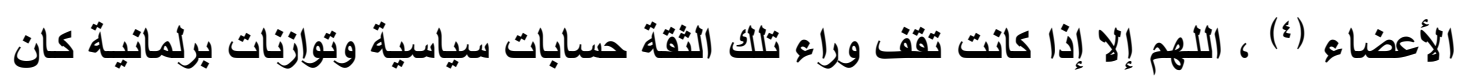

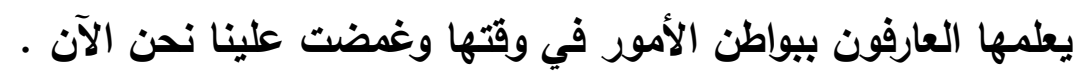

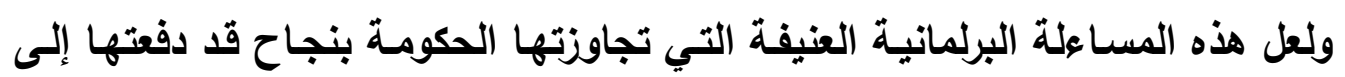
محاولـة استخلاص العبر من تجربـة الهجرة التي أعقبت الغارات الجويـة على الإسكندرية ،

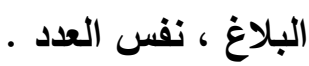

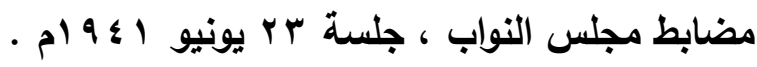

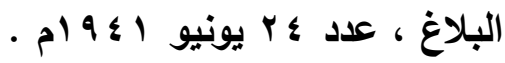

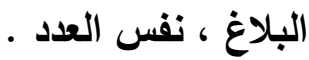


والتفكير فيها بهدوء وعلى نحوٍ عملي ، ولترسم على أساس ذلك سياستها الجديدة التي تنوي

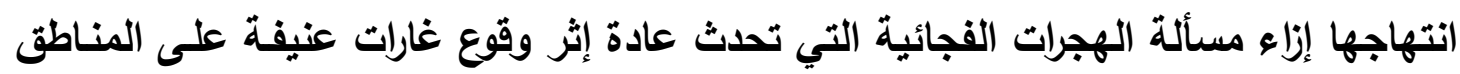
السكنية ، وقد كان من بين هذه العبر المستخلصة : 1-ضرورة وضع مشروعٍ شاملٍ لتظيم الهجرة ، وعدم الحاجة إلى انتظار وقوع الغارات لتنفيذ

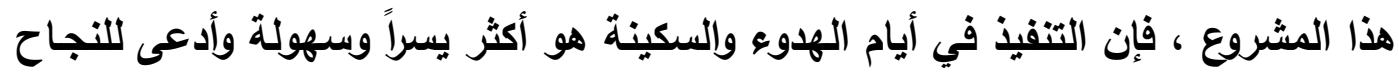

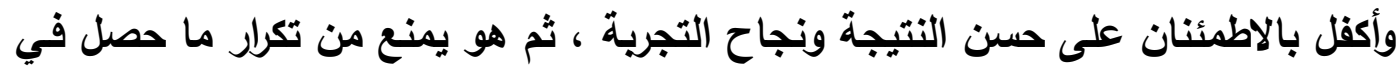

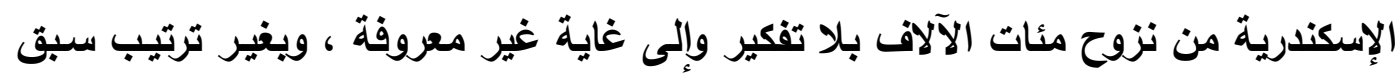

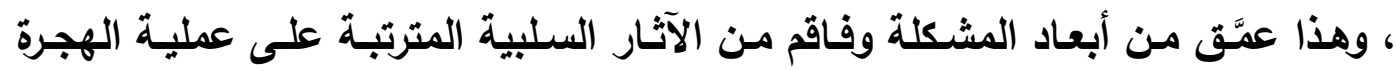
العشوائية هذه ، وضاعف من العبء الذي وجب عن ابعاد الثئ الحكومة أن تتحمله .

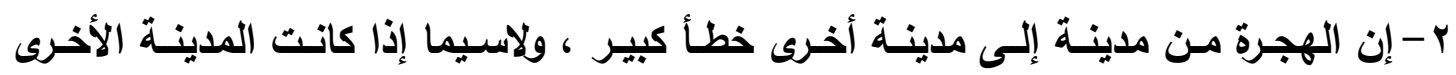

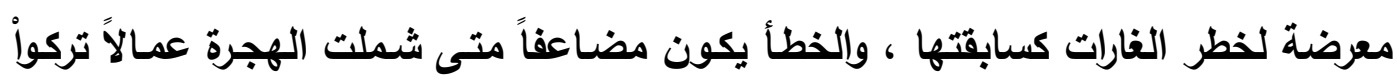

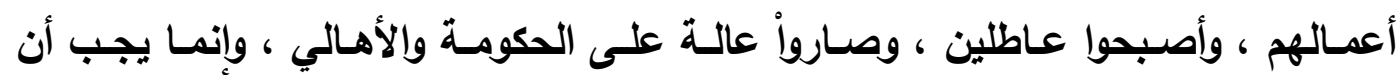

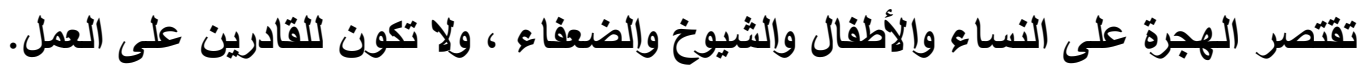

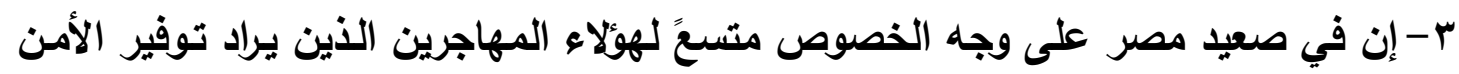

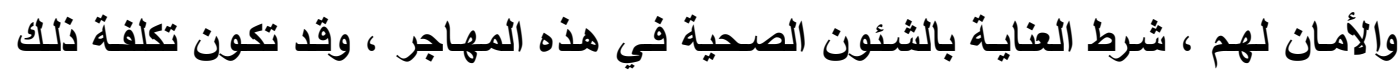
باهظة ، ولكنها لن تذهب عبثاً إذا ساعدت على تحسين الأحوال الصحية في هذه المناطق

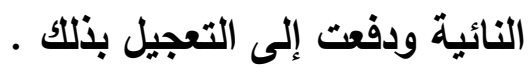

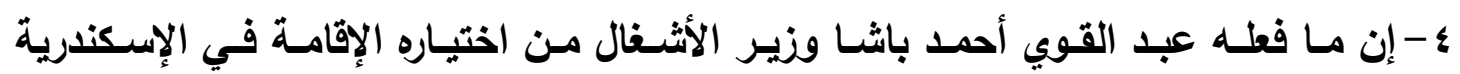

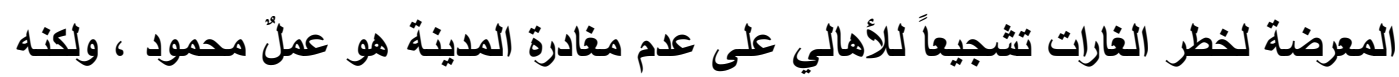

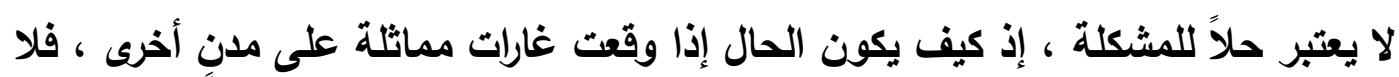

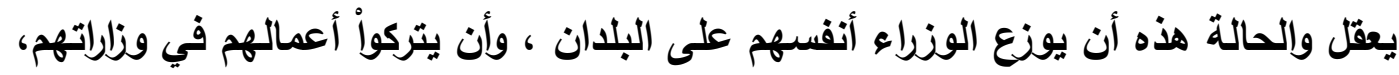

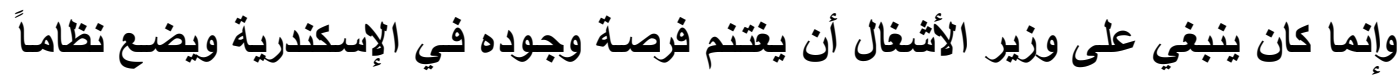

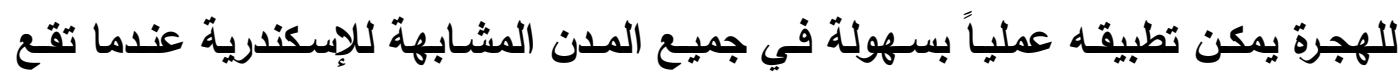
الغارات .

هذه الحقائق المستخلصة - وغيرها - لابد أنها كانت موضوعة نصب أعين رجال الحكومة وهم يتخذون قراراتهم المتعلقة بموضوع الهجرة الناشئة عن الغارات الجويـة ، وريما

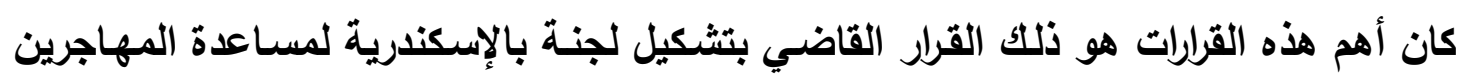

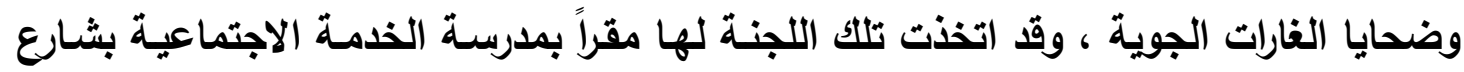

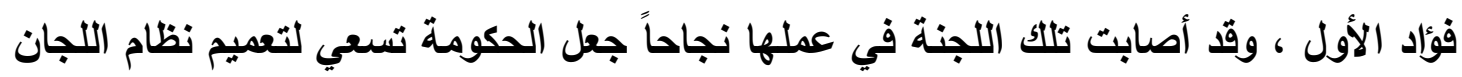




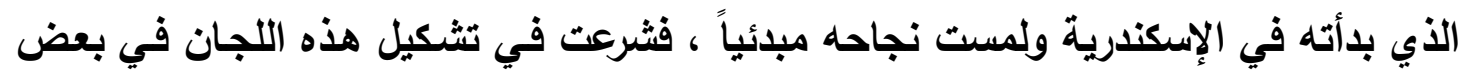

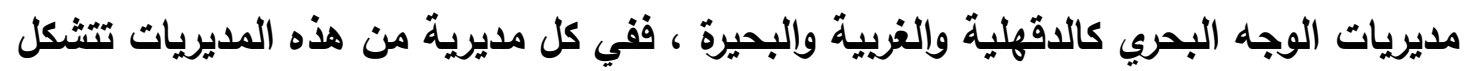

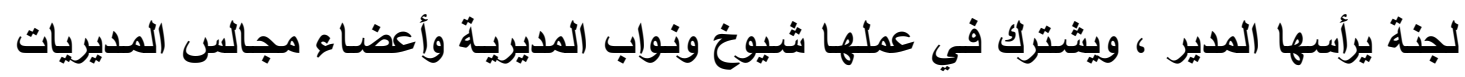

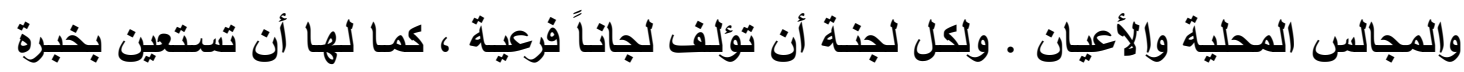

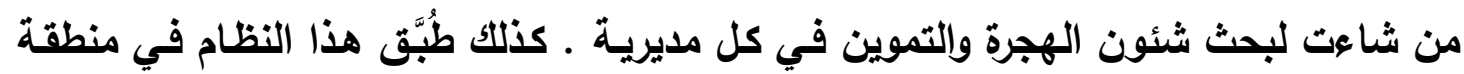

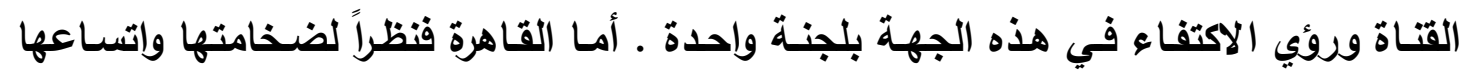

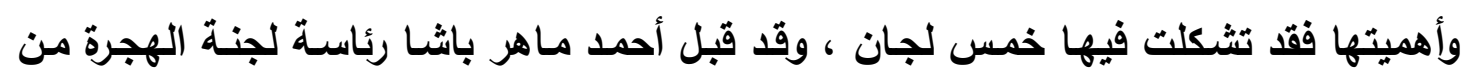
القاهرة وإليها (1)

كما تقرر منع الهجرة إلى مديرية البحيرة لاكتظاظها بالمهاجرين ، وفي خطوة لاحقة

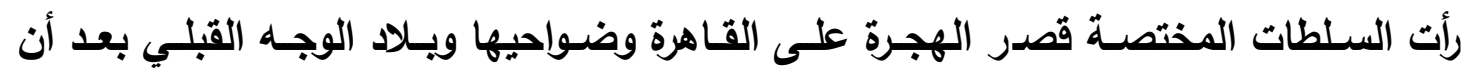

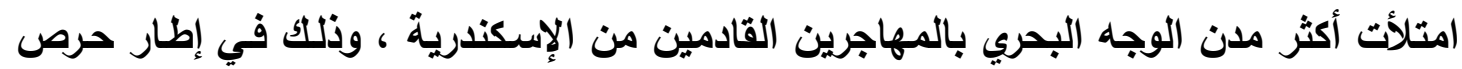

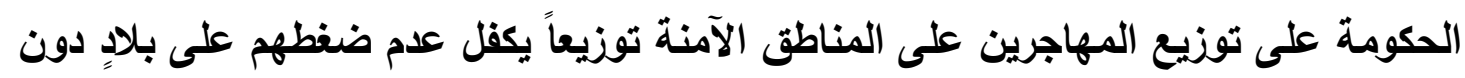

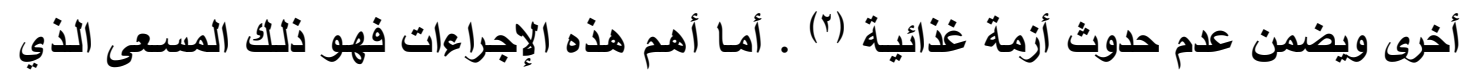

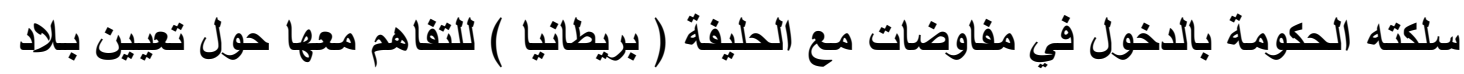

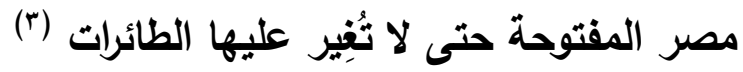

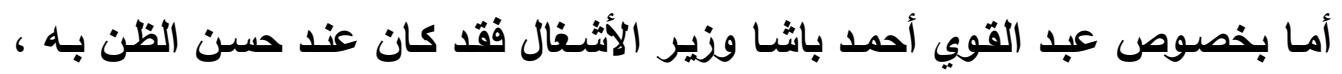

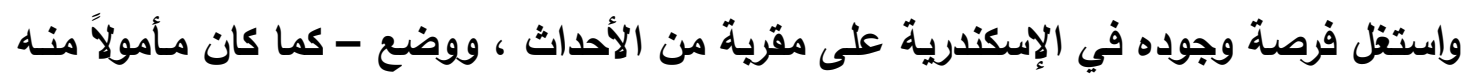

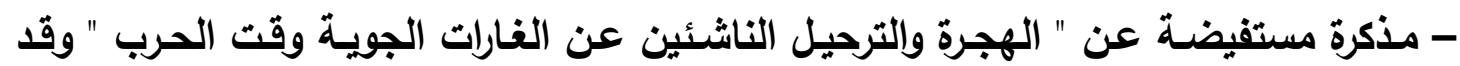

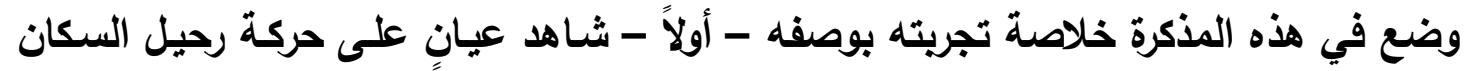

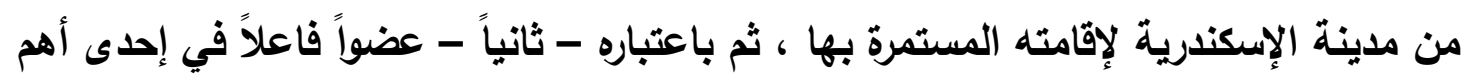

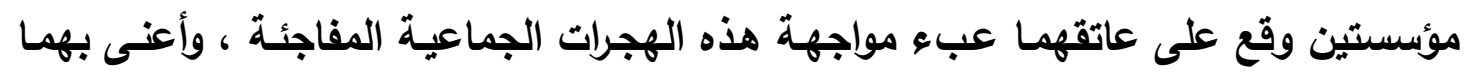

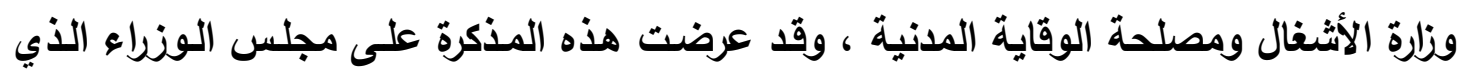

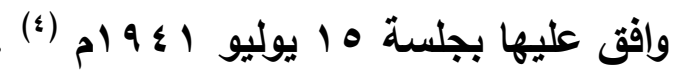

$$
\begin{aligned}
& \text { البلاغ ، عدد ؛ يونيو 1؟ } 9 \text { ام . }
\end{aligned}
$$

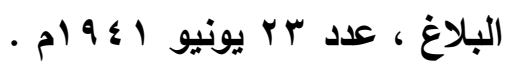

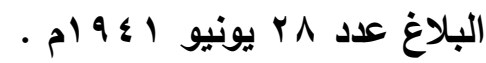

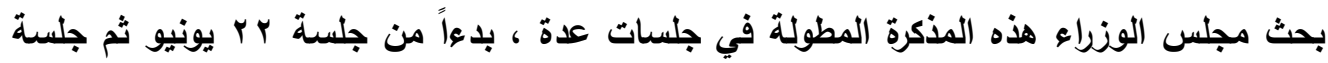

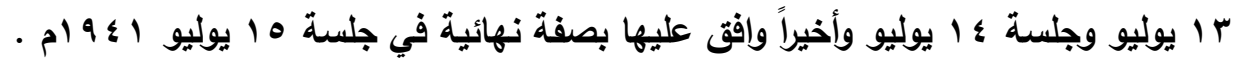
انظر : " المقطم " الأعداد الصادرة في الأيام المذكورة . 
بدأ وزير الأشغال مذكرته بإيضاح كافة الجهود التي قامت بها الحكومات المتعاقبة في

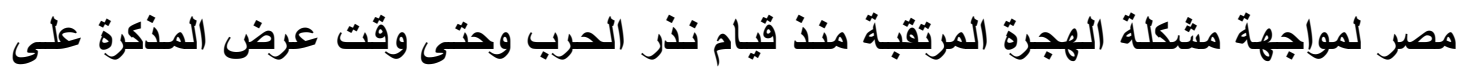

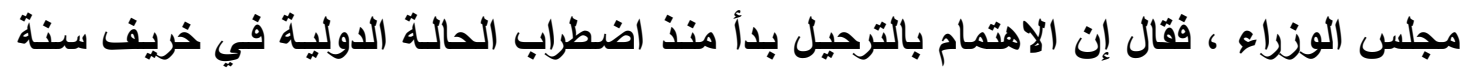

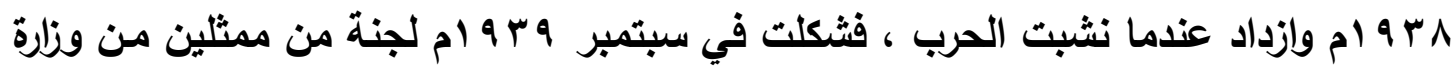

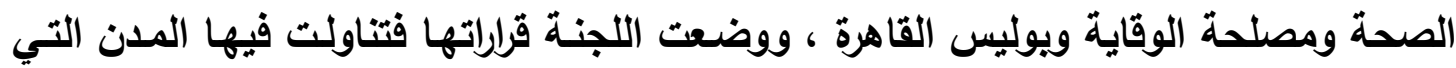

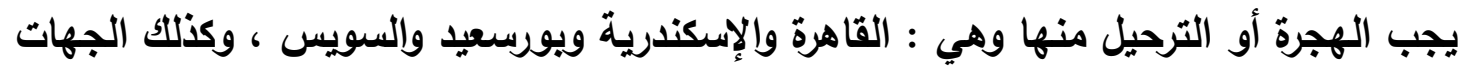

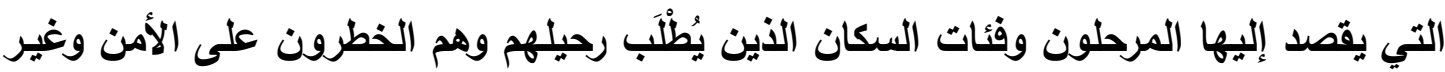
المرغوب فيهم ، والذين ينصح بهجرتهم وهم أطفال الملاجئ وذوو العاهات والكهول والنساء

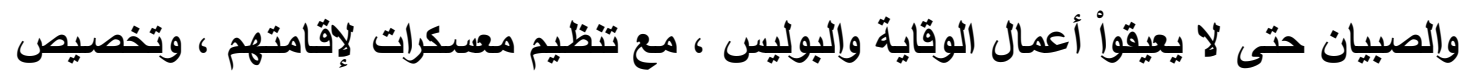

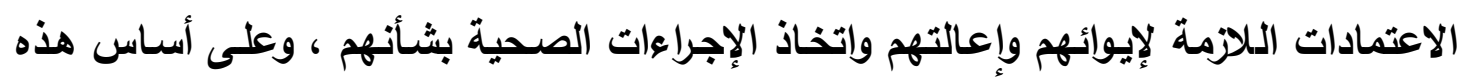
القرارات طلب من المحافظات والمديريات حصر عدد الأشخاص المتوقع هجرتهم فكاتت جملتهم

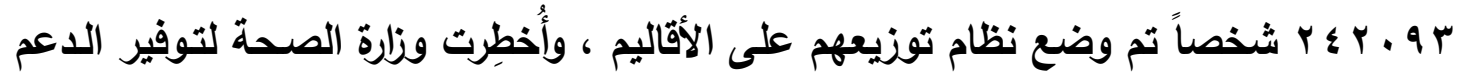
الصحي لهم (1) ولما زاد الثعور باقتراب الخطر من البلاد تقدمت مصلحة الوقاية إلى وزارة الداخلية

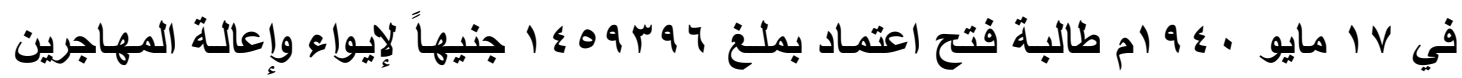

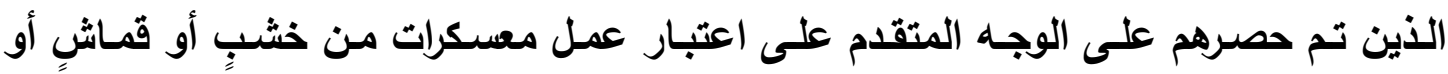

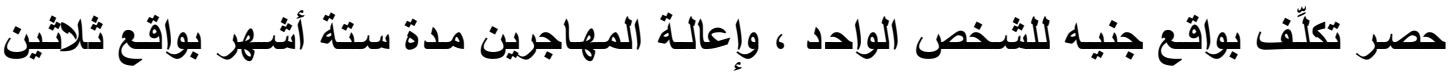

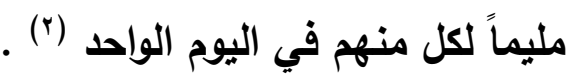

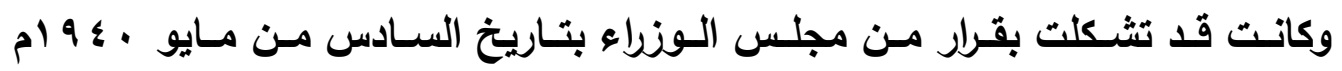

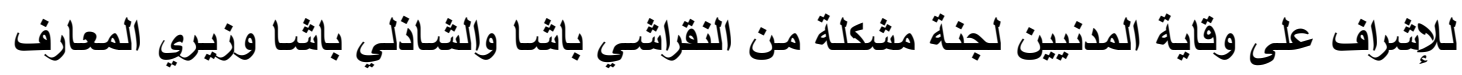

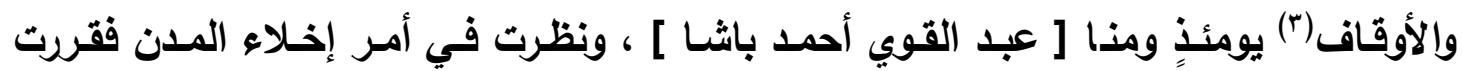

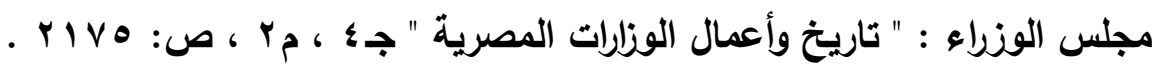

$$
\begin{aligned}
& \text { المصدر السابق ، نفس الجزء والمجلا والصفحة . }
\end{aligned}
$$

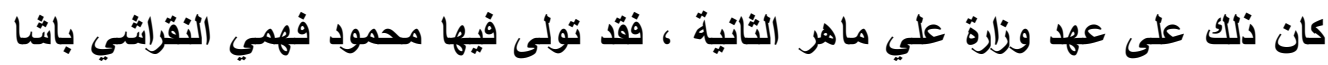

وزارة المعارف ، كما تولى عبد القوي أحمد باشا وزارة الأشغال ، ولكن يلاحظ أن عبد السلام

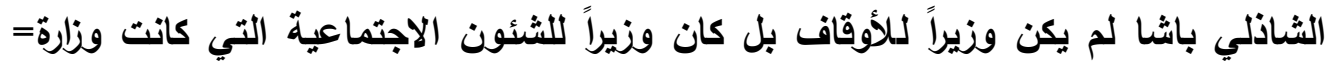

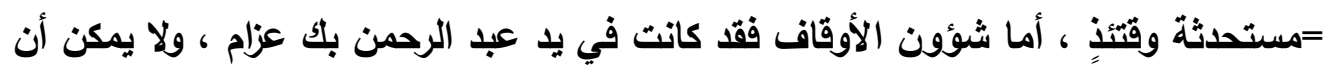
يحمل ذلك إلا على سبيل السهو والنسيان . انظر : يونان لبيب رزق : " تاريخ الوزارات المصرية " ص: 9 اء ـ ـ 
الموافقة على مبدأ الإخـلاء عامـة ، وعلى مبدأ الإخـلاء الجزئسي في مدن القاهرة والإسكندرية

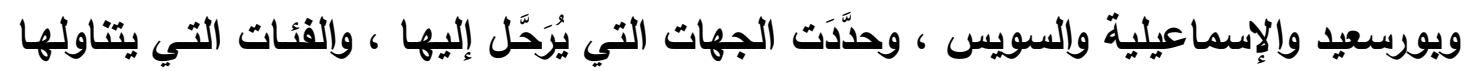
الترحيل والهجرة .

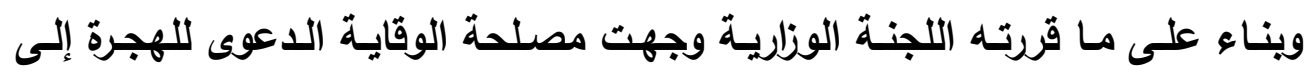

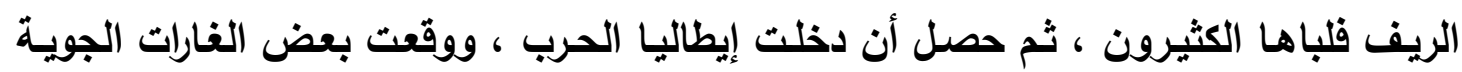

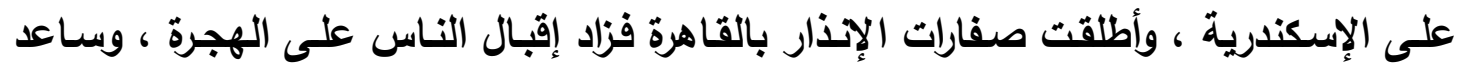

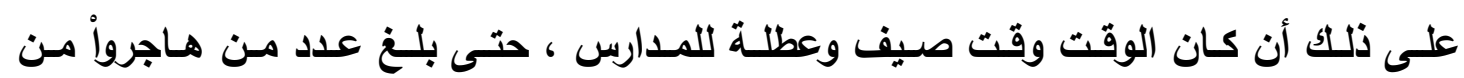

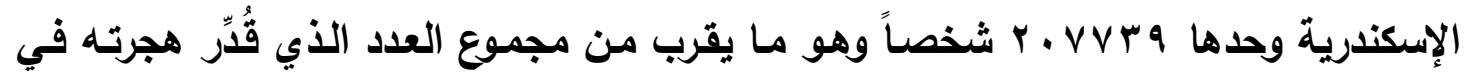

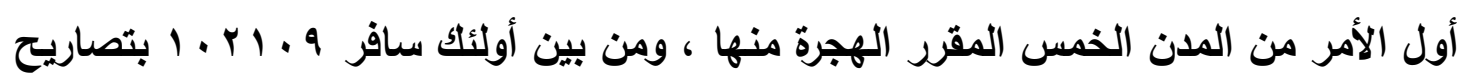
سفر مجانية وقد انتدبت مصلحة الوقاية المدنية بعض موظفيها لتفقد حالة المهاجرين ، ويستفاد من التقارير التي قدموها عن نتيجة مهمته عجز أهل القرى عن استضافة المهاجرين ، وقيام

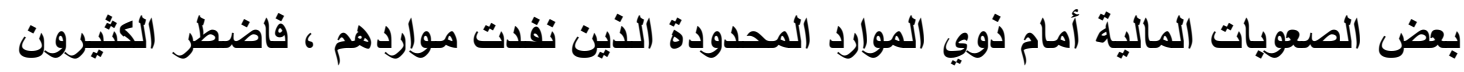

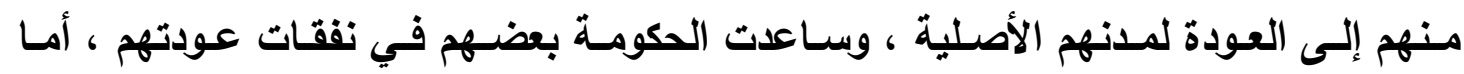

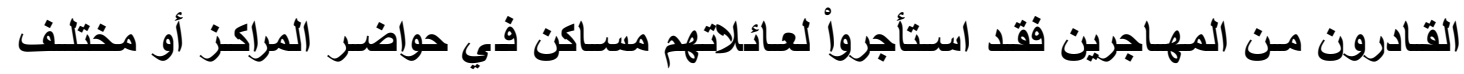

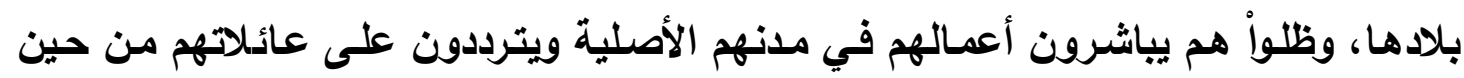

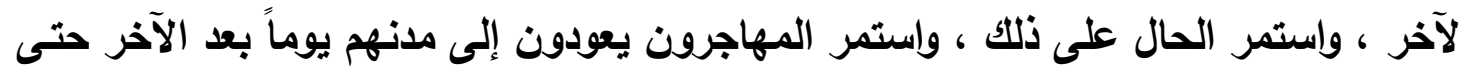
حلَّ موعد افتتاح المدارس فلم يبق أحدُ في مهجره إلا القليل النادر ، أمسا عن الحالـة الصحية الصدية

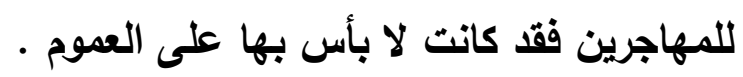

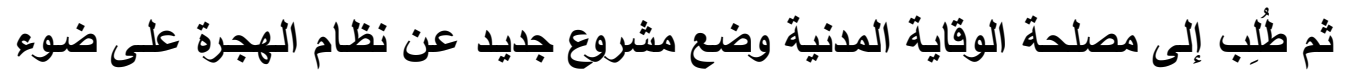

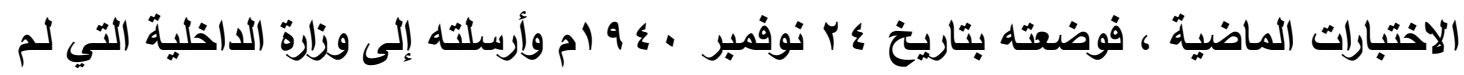
تتخذ فيه قراراً بعد ، ويقوم هذا المشروع على الأسس التالية :

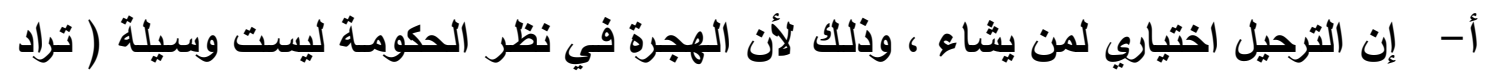
سبياً ) لتشريد الناس ، ولكنها إثراف على سيل المهاجرين وتوجيههم إلى جهات مختارة،

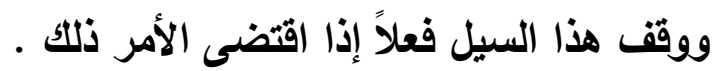
ب- أن تكون هجرة أهل الإسكندرية والسويس ويورسيعيد والإسـماعيلية إلى مديريات الوجـه

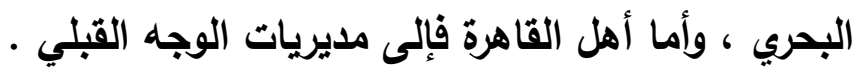
ج- أن تخصص إعانة من مال الدولة تصرف إلى المعوزين حقاً من المهاجرين حتى لا يُشَجََّع على التكاسل . 
د- السعي من جانب الإدارة في إيجاد أعمال للقادرين من المهاجرين في الرعي أو الطرق أو

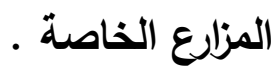

ويعد أن استعرض وزير الأثغال على النحو السابق كافة التجارب السابقة في التعامل

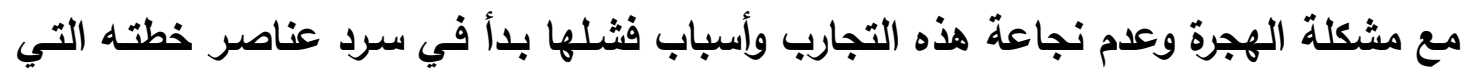
رسمها للتعامل مع هذه المشكلة واضعاً في اعتباره العمل على تفادي مواطن الذلل في التجارب

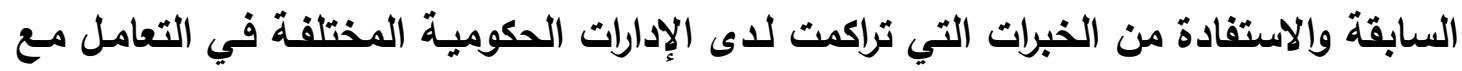
الهجرة بنوعيها : الاختيارية والإجبارية .

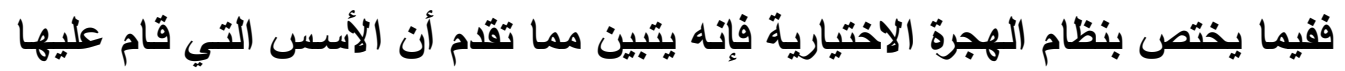

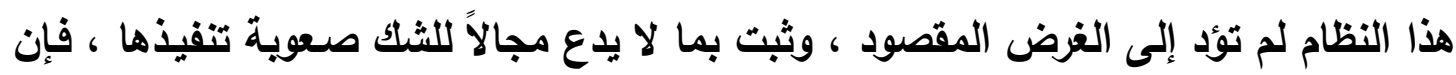

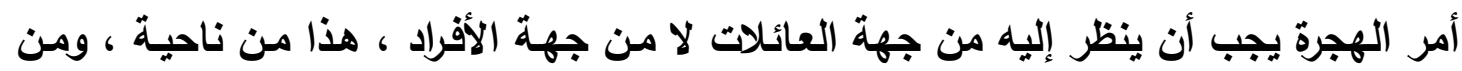

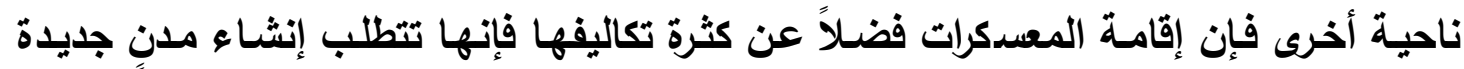

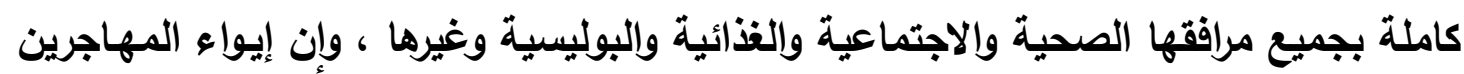

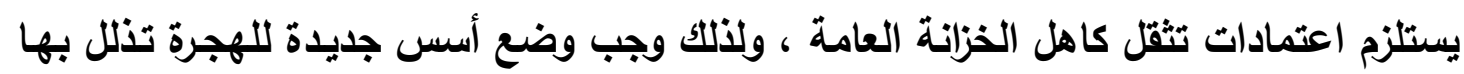

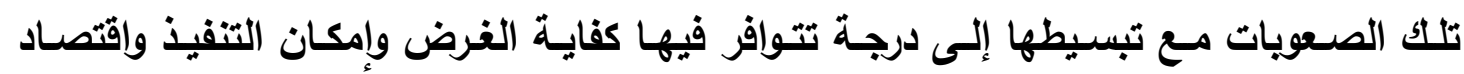
النفقات قر الإمكان ، وهذه الأهداف يمكن تحقيقها بالإجراءات الآتية :

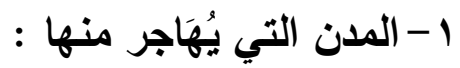

لم يطرأ ما يدعو للتعديل في بيان المدن التي ينصح بالهجرة منها ، وهي : الإسكندرية

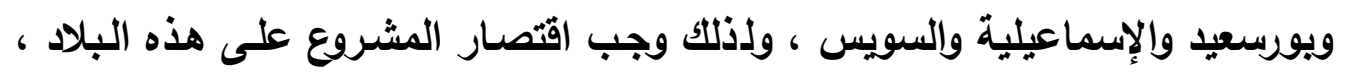

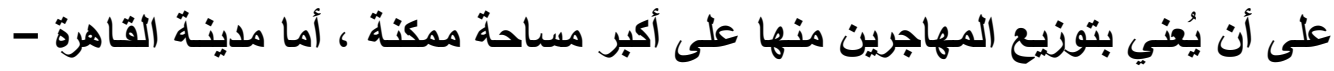

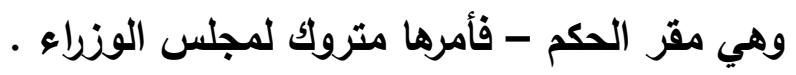
r- الوقت الذي يجب عنده الهجرة :

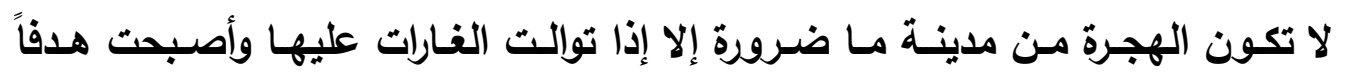

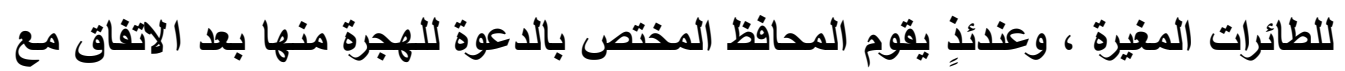

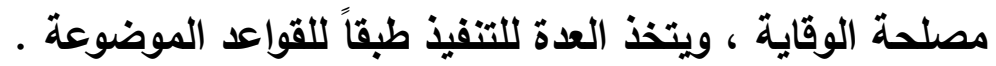
ب-طبقات المهاجرين ونظام هجرتهر : تنقسم طبقات المهاجرين - كسائر طبقات الشسب - إلى ثلاثنة أقسام : الموسرين ومتوسطي الحال وإلفقراء . فأما الموسرون فتكون هجرتهم على نفقتهم دون قيدٍ أو شرطٍ غير إخطار جهة الإدارة

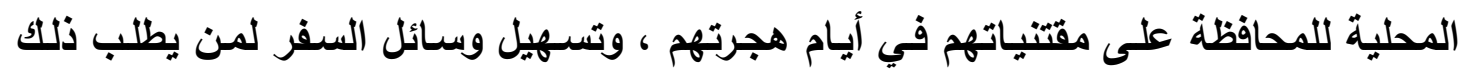


منهز على حسابهم . مان

وأما متوسطو الحال من السكان فينصح لهم بترحيل نسائهم وأطفالهم والعجزة منهم

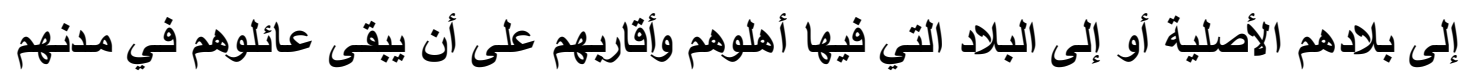

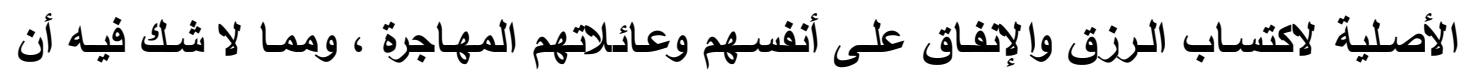

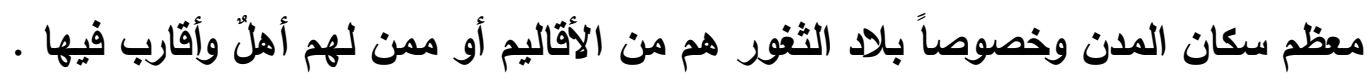

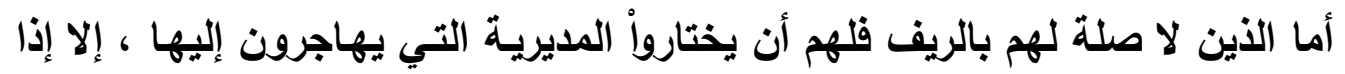

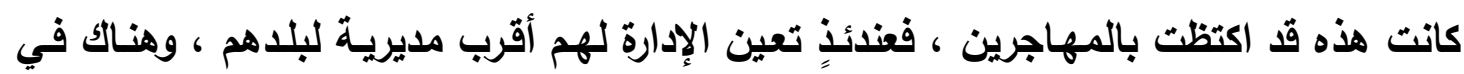

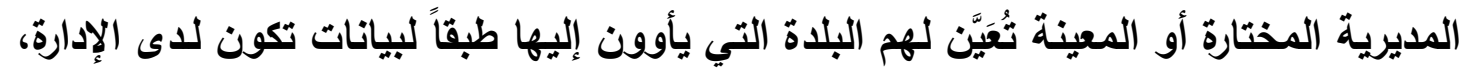

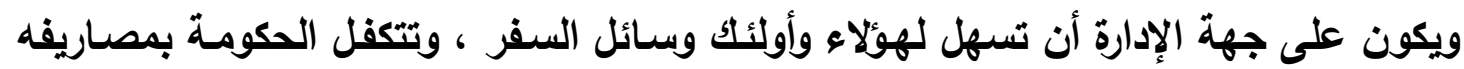
لغير القادرين منهم وذلك بتصاريح سفرِ تصرف لهم مجاناً ، وتعمل الإدارة في جهتي الترحيل

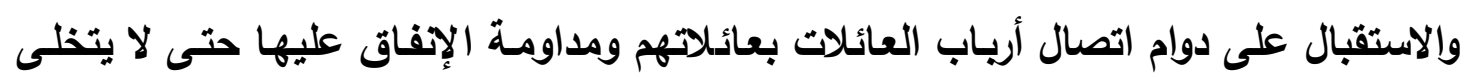

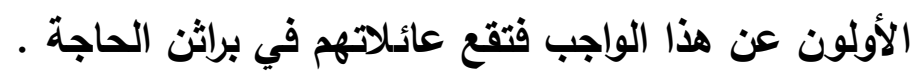

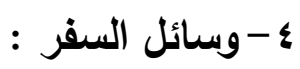
أما وسائل السفر فقد تبين من التجربة الماضية أنه مي كثرة عدد الأثخاص الذين

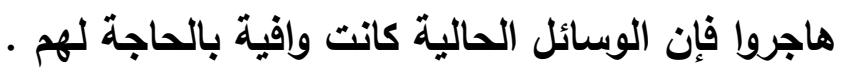
ه- الاستعدادات التمهيدية للترحيل :

فإذا ما تقررت هذه المبادئ فإنه يتعين اتخاذ الإجراءات الآتية منذ الآن :

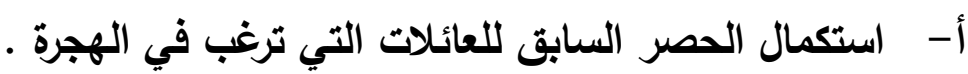
ب- يطلب إلى المديريات إعادة حصر مكاتب التعليم إلزامية أو أولية ، والمنازل او أجزاء ألماء

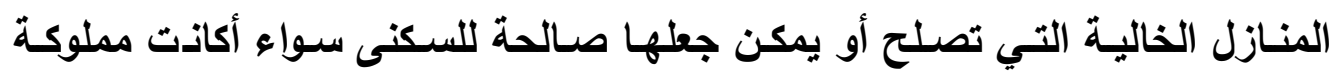

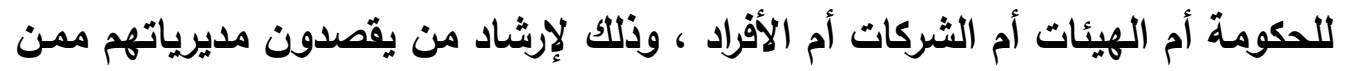

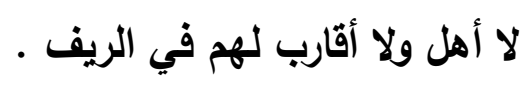

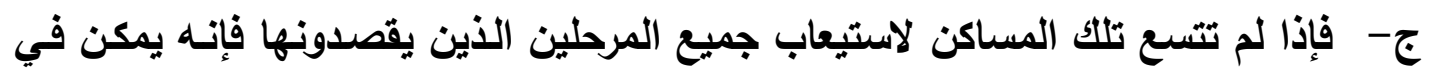

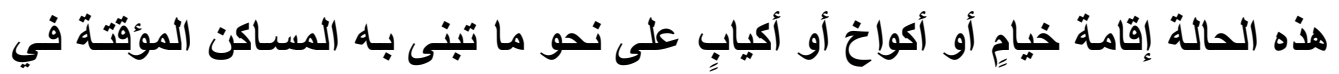
المصايف . المده د- ت تفادياً من ارتفاع أجور المساكن في المديريات المهاجر إليها كما وقع في هجرة السنة

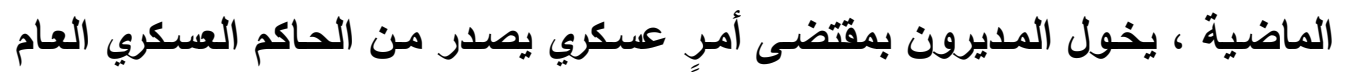

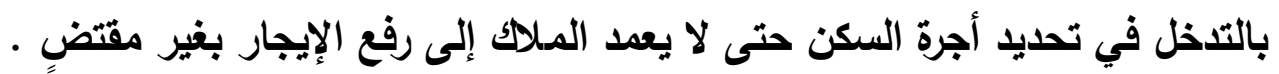
أما فيما يختص بالترحيل الإجباري فإنه يكون في حالتين : 
الأولـى : بالنسـبة للأثــخاص الخطرين على الأمسن والنظـام وغير المرغوب فيهم وإجراءات هذا النوع من الترحيل مقررة من قبل ، فالأثخاص الذين ينطب الاهن فئن عليهم تم إبعادهم

والثانيـة : تكون في حالـة إخـلاء مدينـة أو جزء مـن مدينـة لضـرورات حربيـة تراهـا

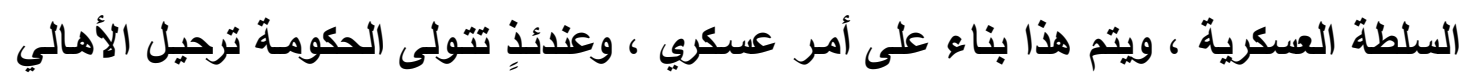

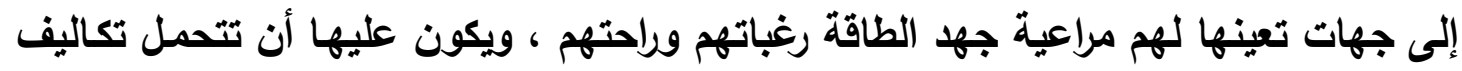

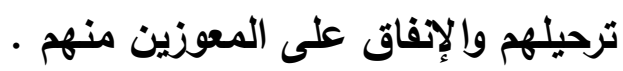

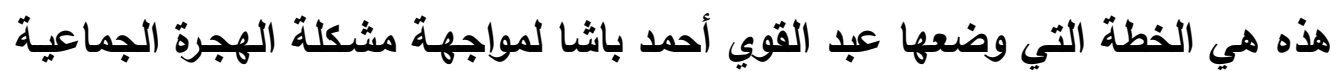

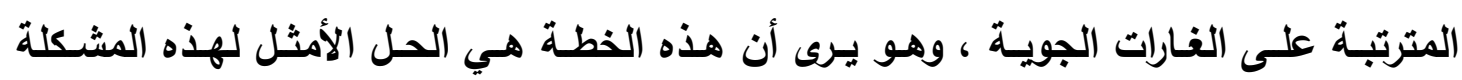

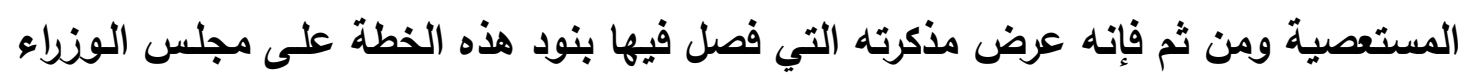
ليحظى بموافقة أعضاء المجلس على الإجراءات التالية :

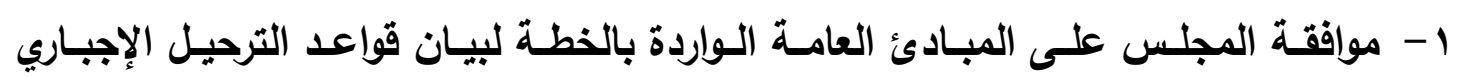
والاختياري . r - موافقة المجلس على أن تتولى مصلحة الوقايـة المدنية أمر إعداد المدارس الحكوميـة

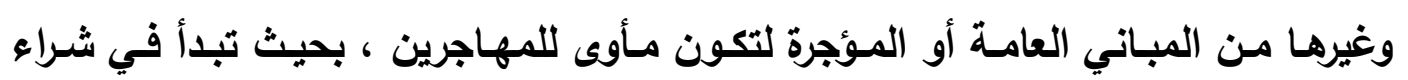

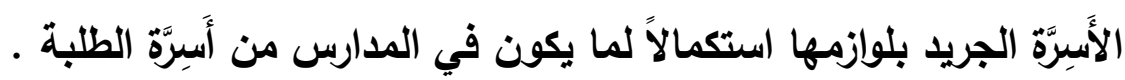

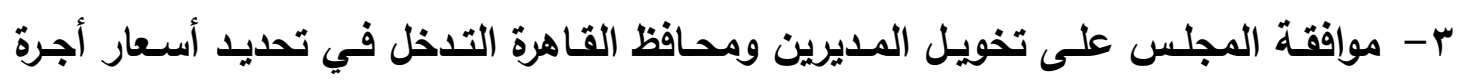

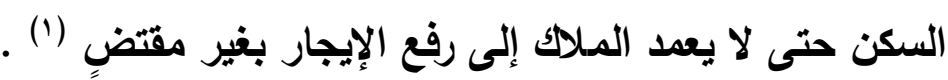

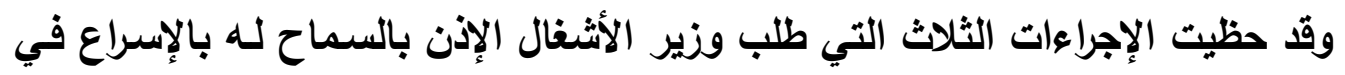

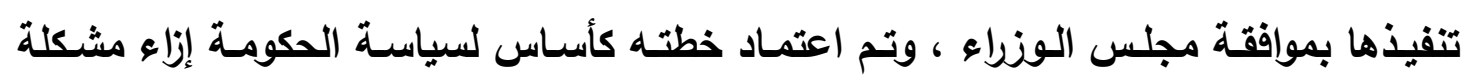

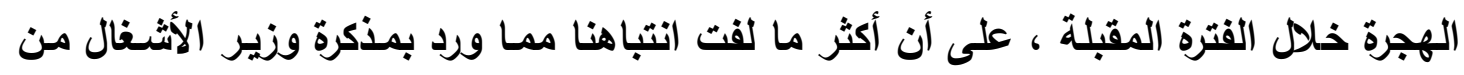

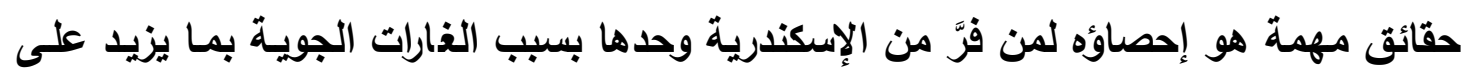

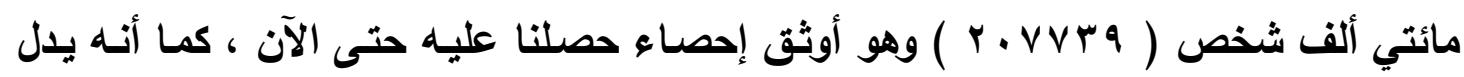

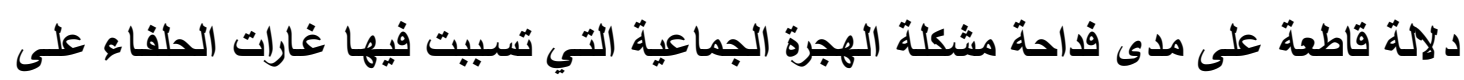

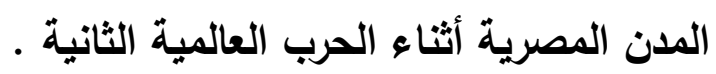

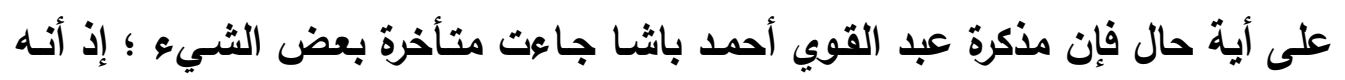

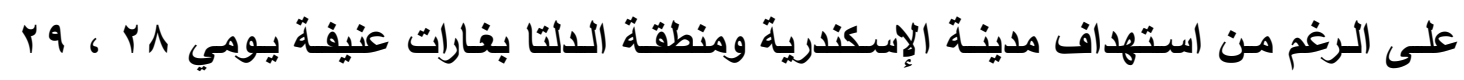

أوردت صحيفة " البلاغ " نص المذكرة كاملاً في عددها الصادر في ؛ يوليو اء؟ ام قبل

إقرار مجلس الوزراء لها بصورة نهائية . 


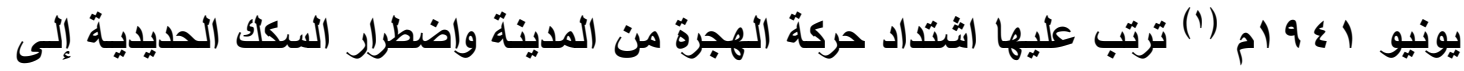

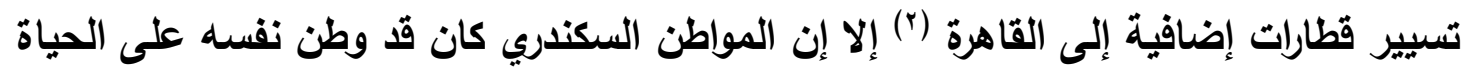

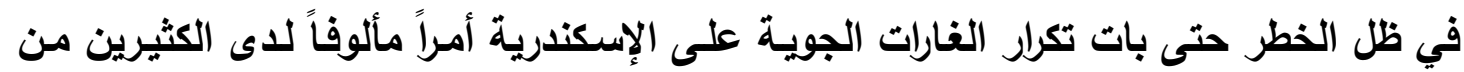

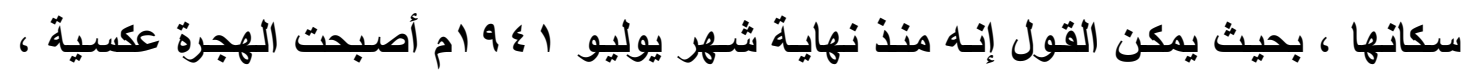

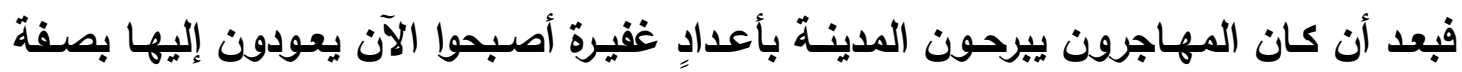

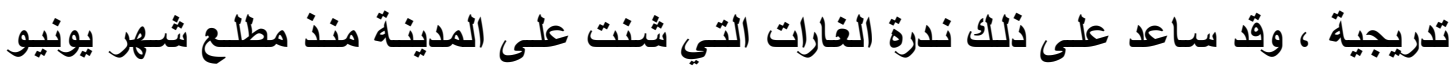

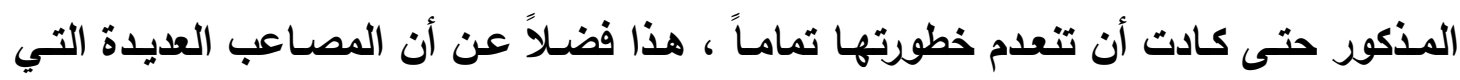

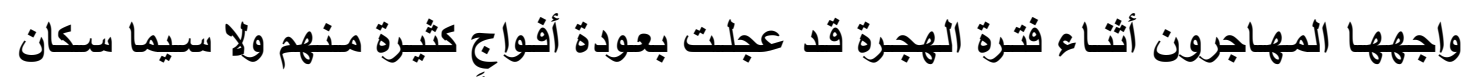

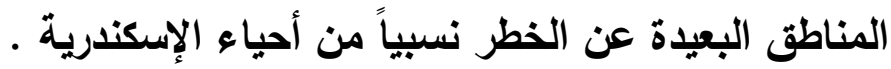

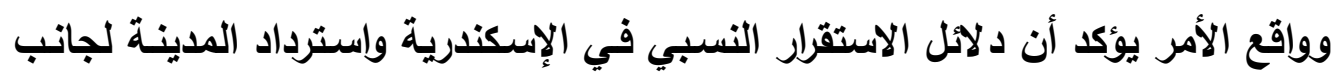

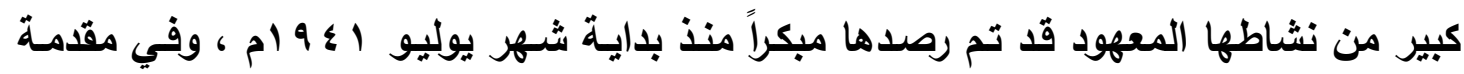

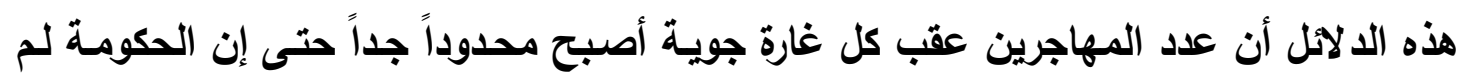

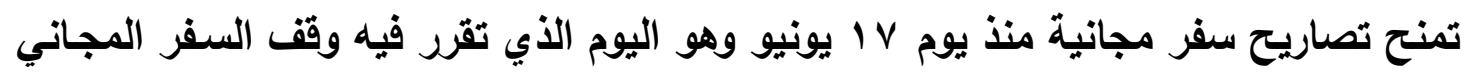

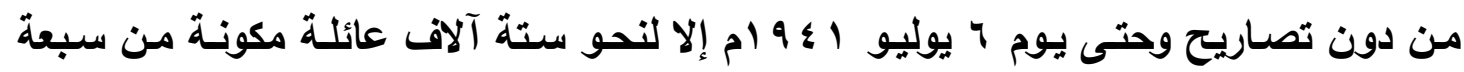

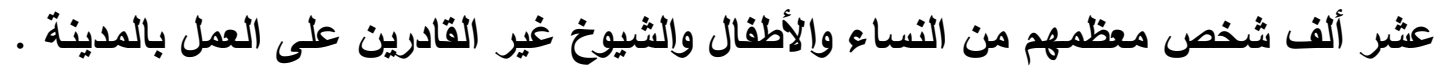

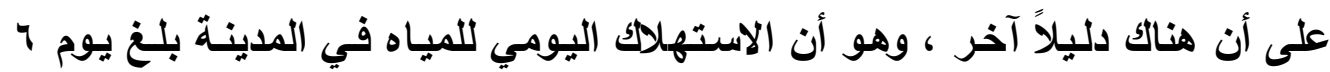

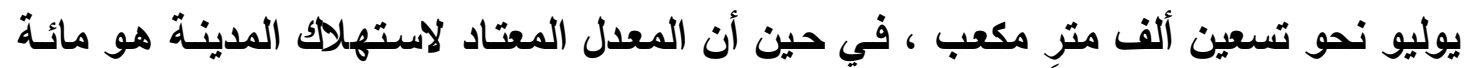
وعشرون ألف متر مكعب من المياه .

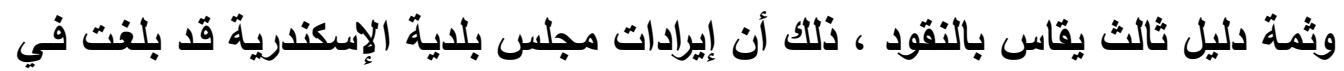

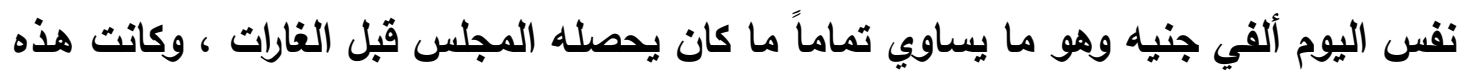

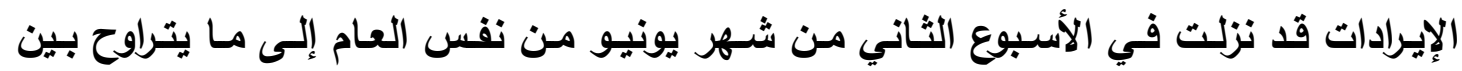

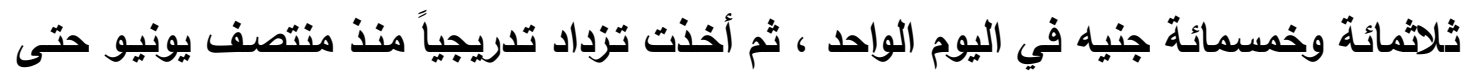

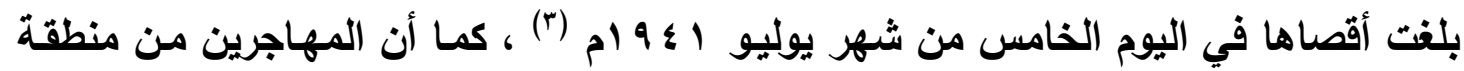

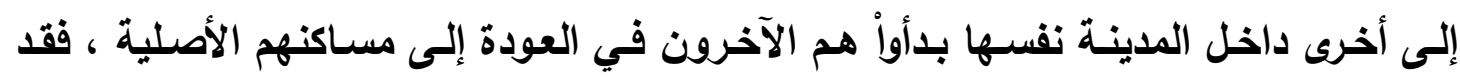

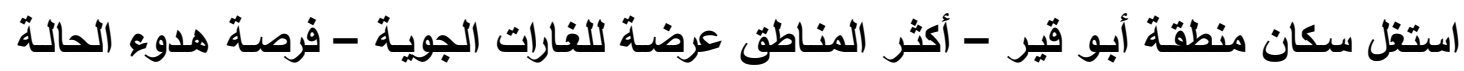
وانخفاض ضغط الغارات واخذواً في العودة إلى منطقتهم حتى وصل عدد العائدين إلى نحو إنى

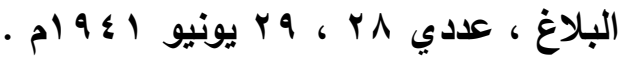

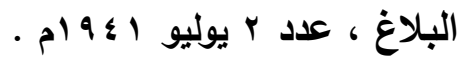

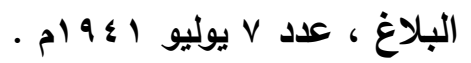


نصف عدد المهاجرين بنهاية الثهر المذكور (1) .

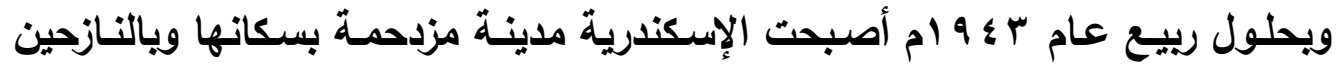

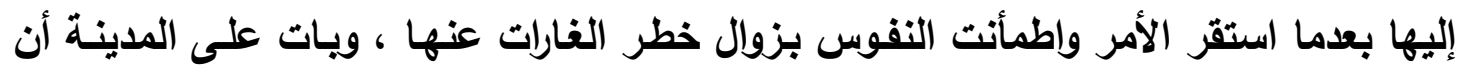

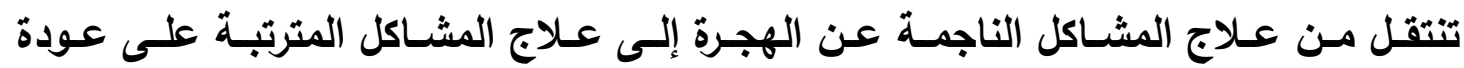

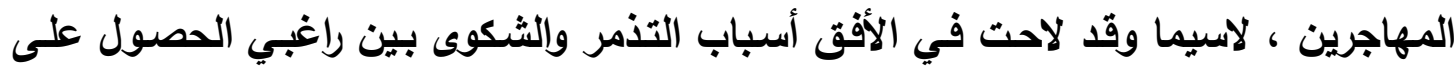

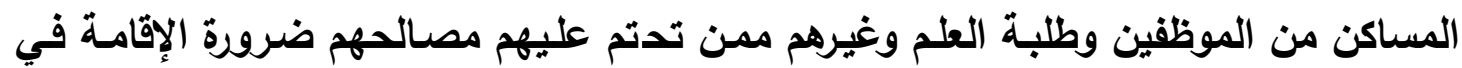
المدينة ، خاصة بعد أن أصيب كثيرٌ من المباني في المدينة بالهدم والتخريب بسبب الغارات

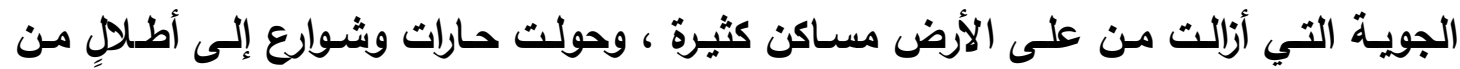

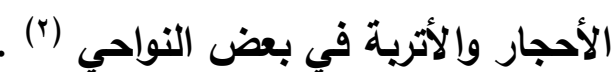
ولم تجد لجنة الهجرة بمحافظة الإسكندرية في اجتماعها الذي عقدته في شهر يونيو لواليو من عام بـ 9 ام ما يدعوها إلى الاستمرار في تنفيذ المشروع الذي كان معداً سلفاً لترحيل

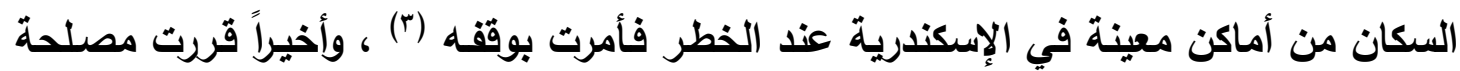
السكك الحديدية إلغاء القطار الإضافي الذي كان ينقل مهاجئه الإنكائ عدي الإسكندرية إلى مناطق الوجها

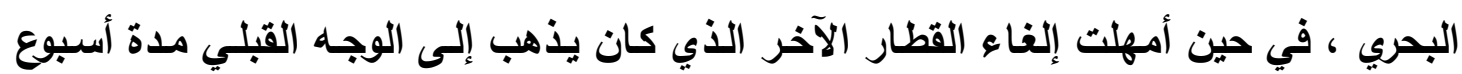

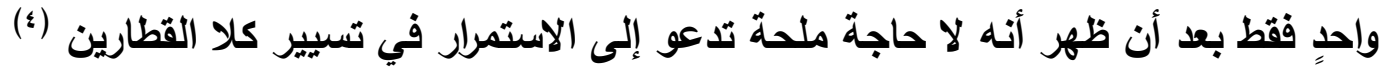

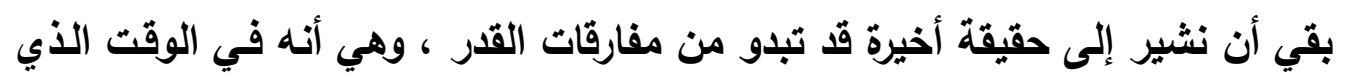

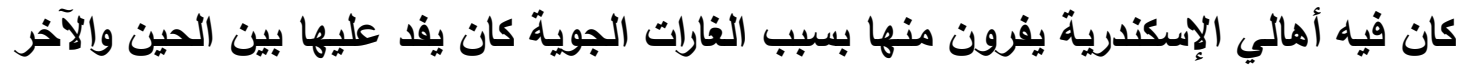

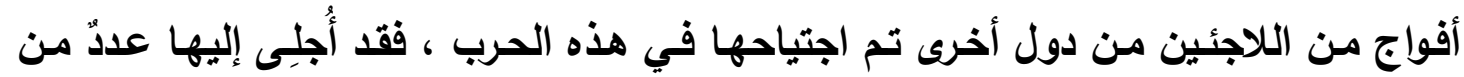

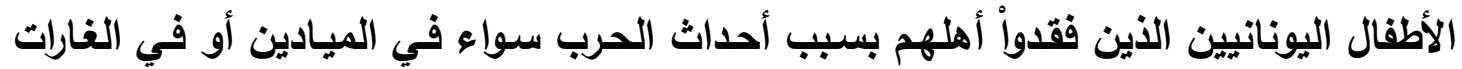

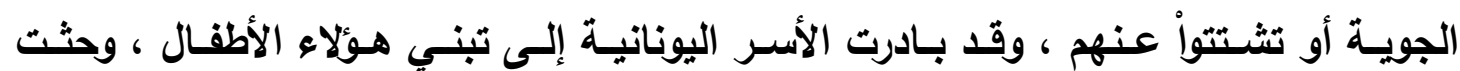
القتصلية اليونانية الموسرين على التبرع لهم (0) ، كما سمحت المفوضية الئهية اليونانية للاجئين

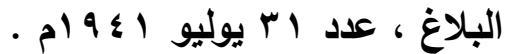

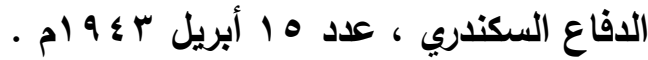

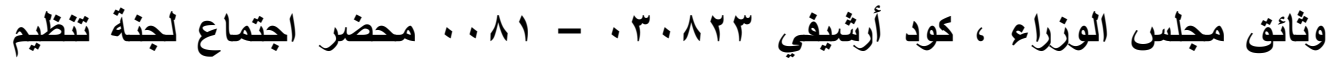

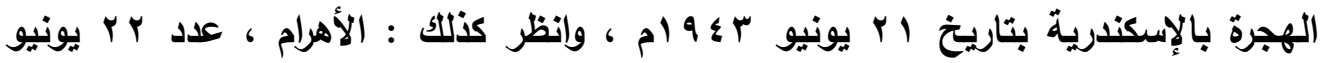

$$
\begin{aligned}
& \text { الأهرام ، عدد } 9 \text { ايوليو بـ } 9 \text { ام . }
\end{aligned}
$$

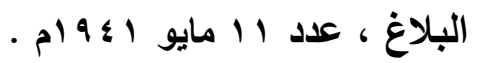


واللاجئات من اليونانيين بالسفر إلى جنوب أفريقيا متى أبدواً رغبة في ذلك (1) ، كذلك حملت

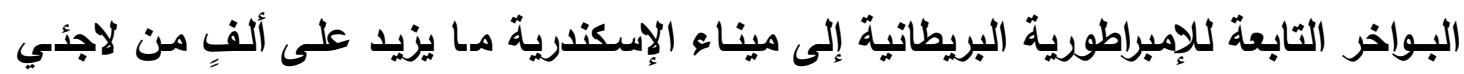

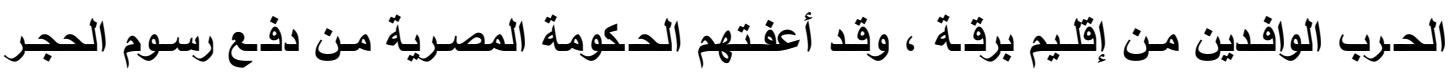

المهاجرون من منطقة القناة (") : الميجي

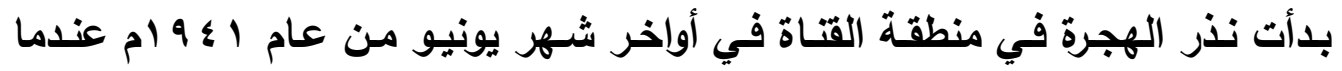
اتصل محافظ القتاة بوزير الأثغال وطلب منه مخاطبة مصلحة السكك الحديدية لإعداد قطارات

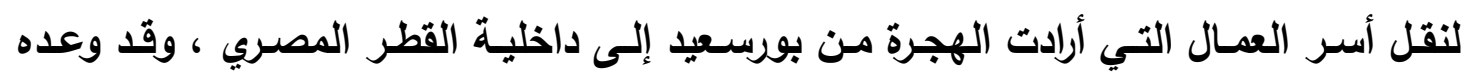

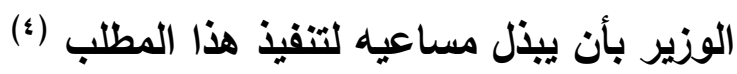
وفي محافظة السويس دفع توالي الغارات الجوية على مدينة الإسكندرية واثثتاد رحيل

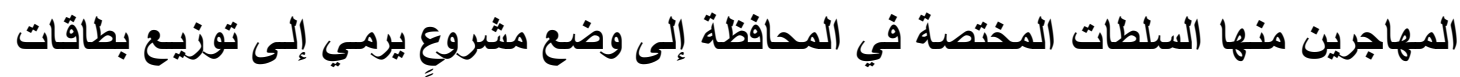

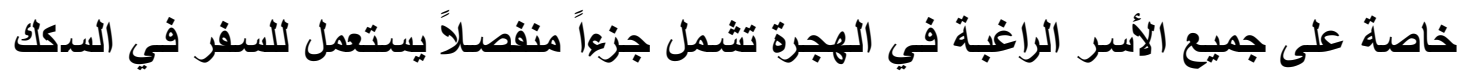

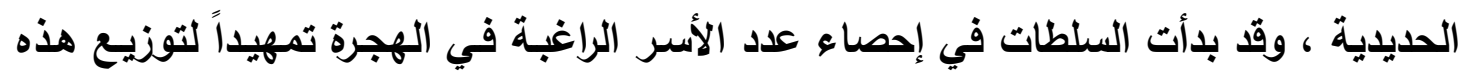

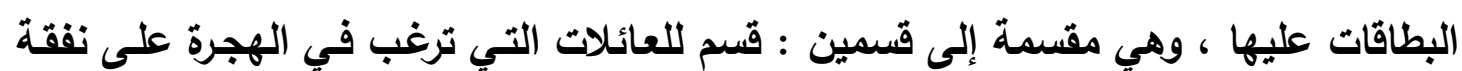

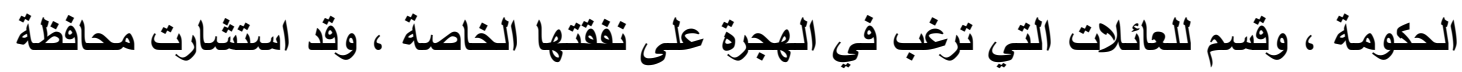

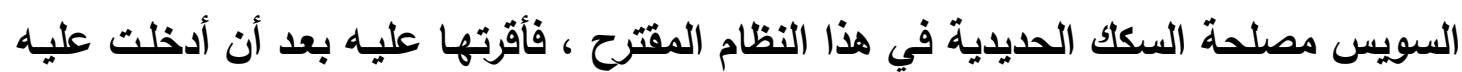

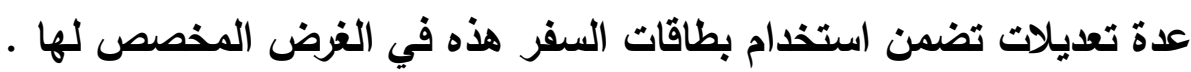

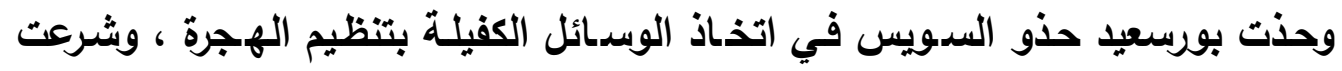

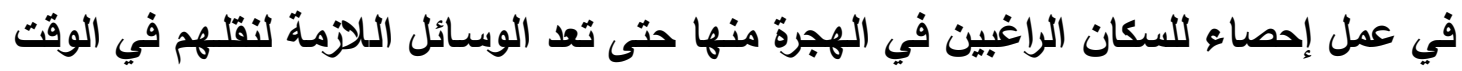
(المحدد (0) إنمي

وكانت الهجرة من مدينة السويس تتم بشكلٍ تدريجي في أواخر شهر يونيو اء 9 ام ،

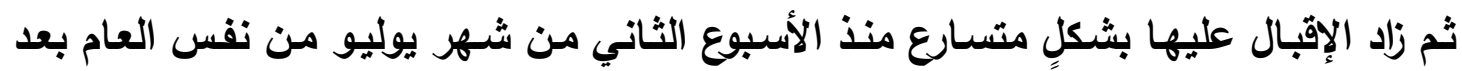

$$
\begin{aligned}
& \text { البلاغ ، عدد VI يونيو إ } 9 \text { ام . }
\end{aligned}
$$

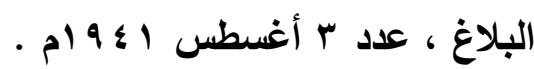

كانت منطقة القتاة تتكون من محافظة القتاة التي تثمل مدن الإسماعيلية ويورسعيد

ويورفؤاد بالإضافة إلى محافظة السويس .

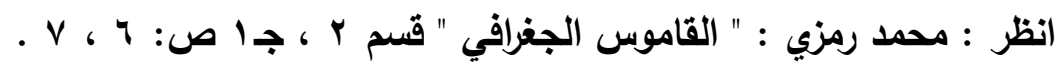

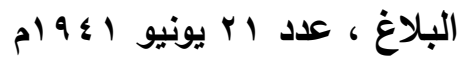

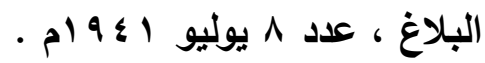


وقوع بعض الغارات على المدينـة ، فأخذ فقراء المهاجرين يسافرون بتصـاريح سفرٍ مجانية

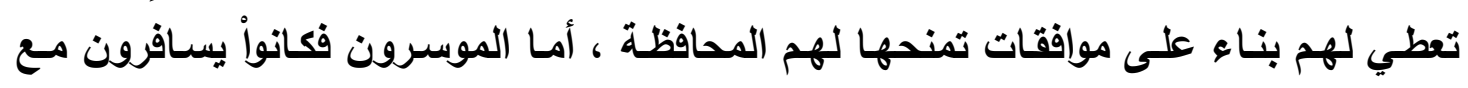

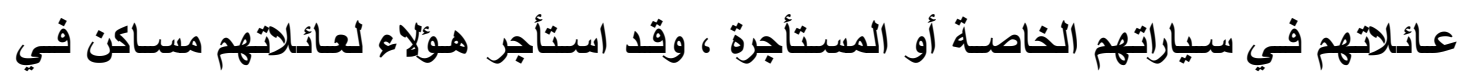
الزقازيق أو القاهرة وغيرها من البلدان (1)

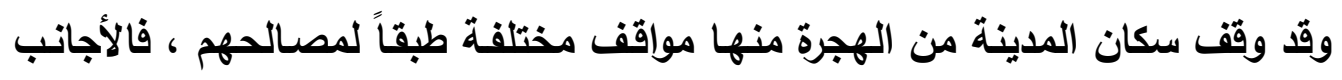

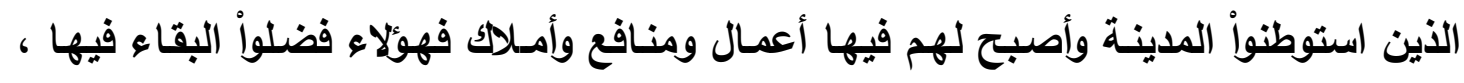

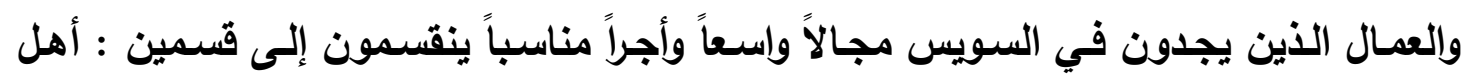

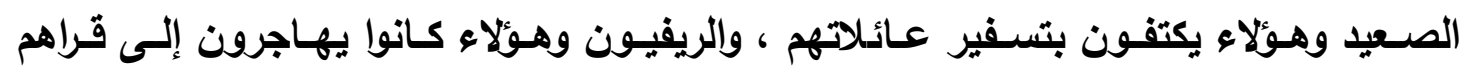

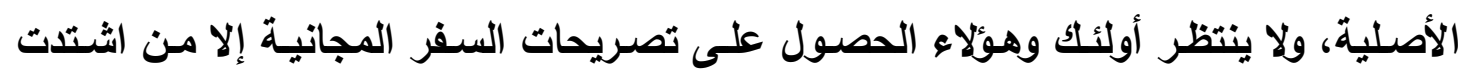

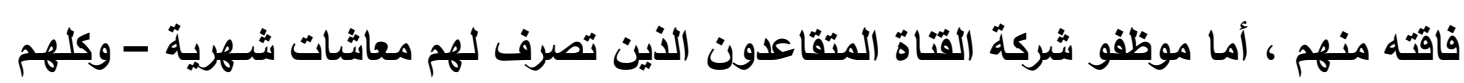

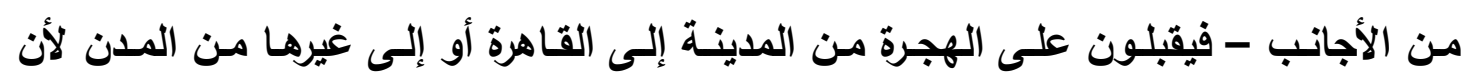

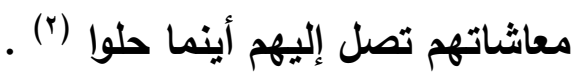

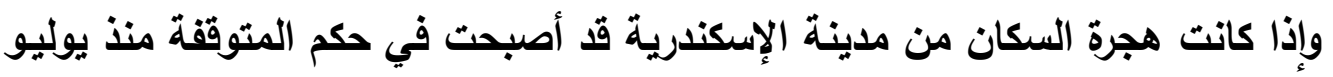

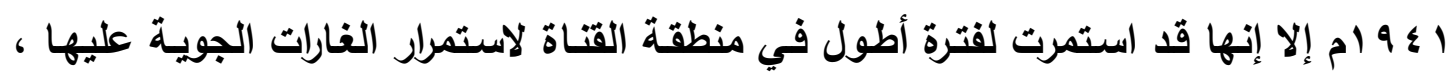

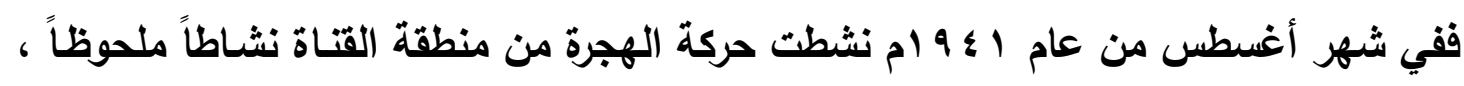
وزاد عدد الراغبين في السفر زيادة أصبحت لا تفي معها القطارات العاديـة ، ورأت مصلحة السكك العديدية تسيير قطارات إضافية ، فسيرت في الخامس من الثـهر المذكور أربعة منها فياديا

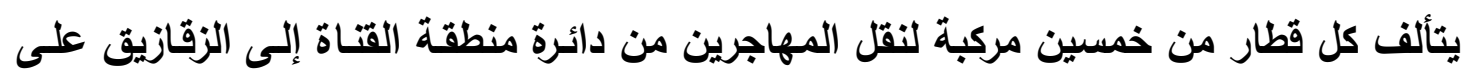

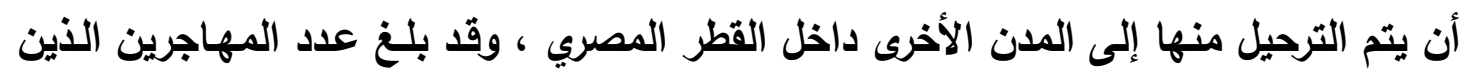

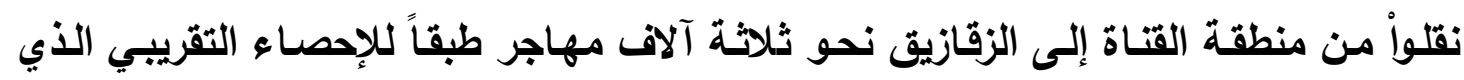

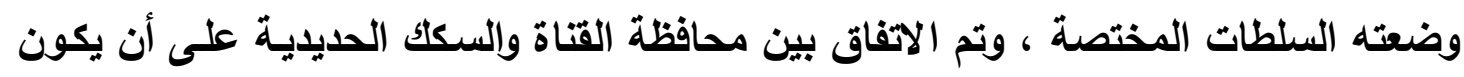

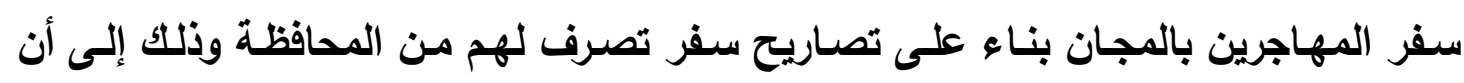

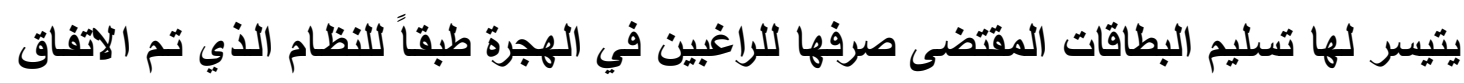

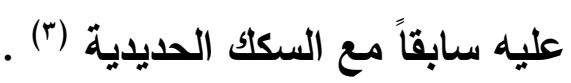

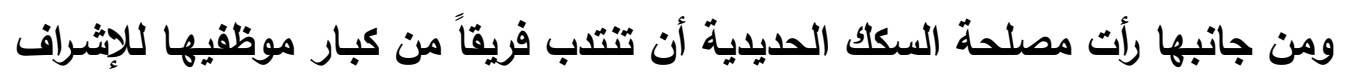

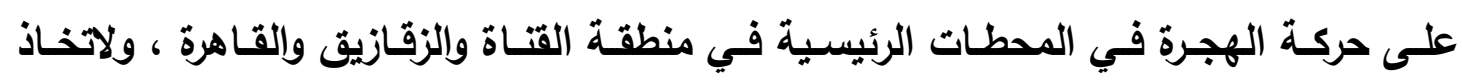

$$
\begin{aligned}
& \text { البلاغ ، عدد 11 يوليو 19 أم . }
\end{aligned}
$$

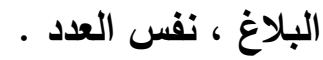

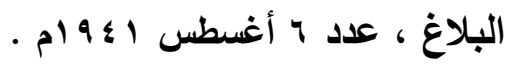


الوسـائل العاجلة لتسـهيل نقل المهاجرين ، ومعالجة الظروف التي تتصل بحركة نقلهم دون التعارض مع حركة النقل العادية (1)

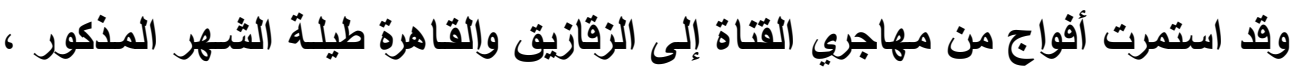

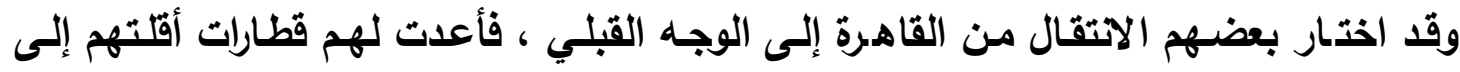

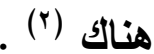

ويبدو أنـه لم تكن هناك خطط مقررة للدى الحكومـة المصرية لإعداد أمـاكن خاصـة لإيواء المهاجرين من منطقة القتاة على غرار ما اتبع بالنسبة لمهاجري الإسكندرية ، فعندما

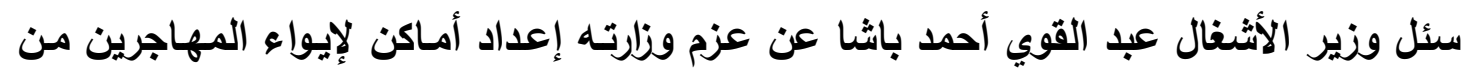

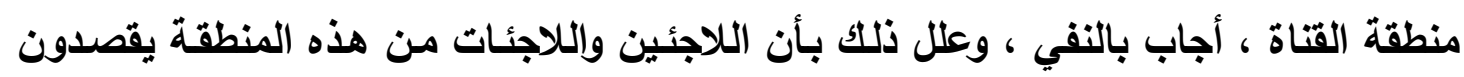

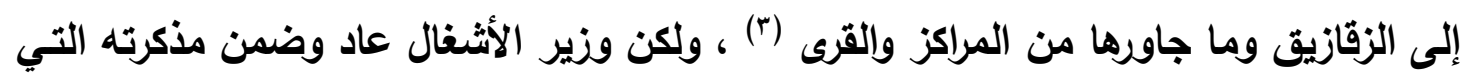

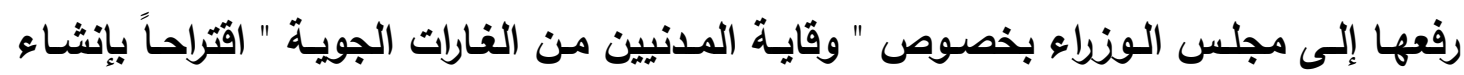
خمس قرى لهجرة أهل القتاة (؛) ، ورد مجلس الوزراء بتكليفه - أي زير الأثشال - باختيار

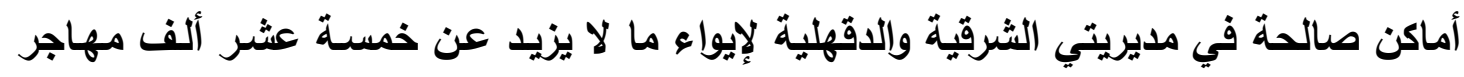

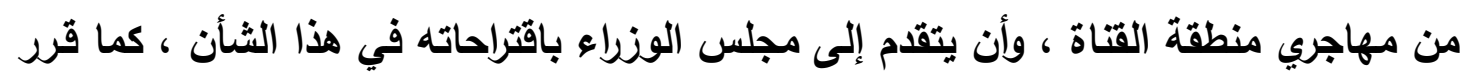

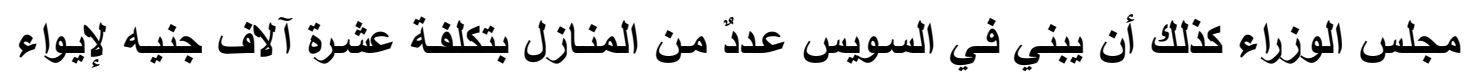
اللاجئين ، وقد روعي في اختيار هذه الأماكن أن تكون صالحة بعد الحرب لسكنى العمال (॰).

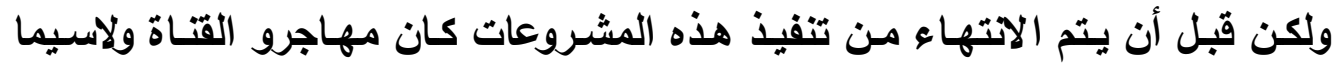

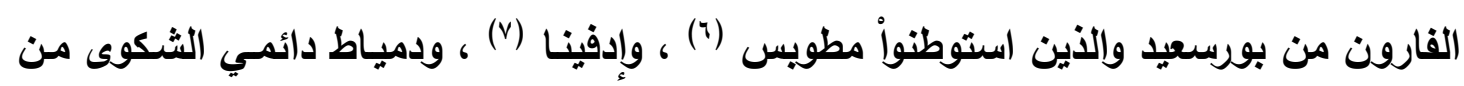

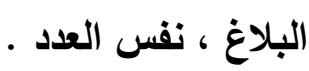

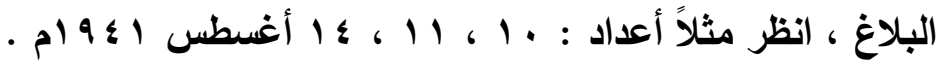

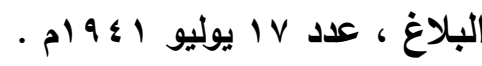

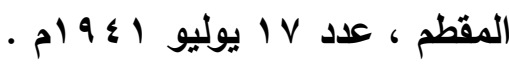

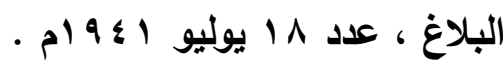

مطويس : قرية قديمة كانت تتبع - في حينها - مركز فوله فئه - مديرية الغربية ، اسمها

الأصلي " نطويس الرمان " ثم حرفت واختصرت إلى اسمها الحالي .

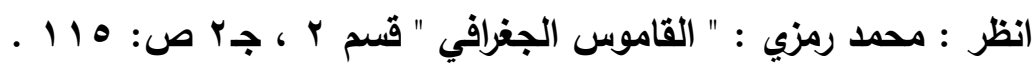

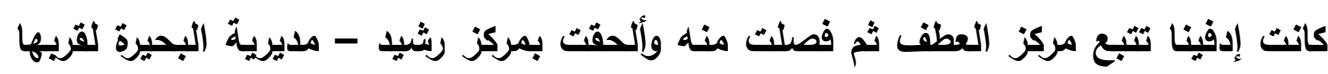

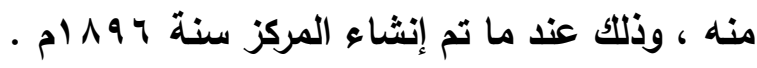

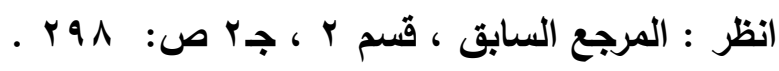


عدم توفر وسائل المواصلات الملائمـة لتنقلهم المستمر بين موطنهم الأصلي ويبين مهاجرهم بسبب قلة السيارات وارتفاع أجورها وإزدحامها بالركاب وعدم وجود مواعيد ثابتة لتحركها ( () ، وكساتواً يناشـدون المختصين تسـهيل الاتقـال لهم وتخفيض أجهور السـفر بالسـكك الحديديـة ومنحهم اشتراكات خاصـة أسوة بمـا هو متبع مـع مهاجري الإسكندرية المقيمين في دمنهور وكفر الدوار (r)

ويالإضـافة إلى هجرة السـكان مـن المنـاطق التـي ذكرناهـا بسـبب الغـارات الجويـة فقــ اقتضت ضرورات الحرب إخلاء منـاطق كاملة من قاطنيها وتهجيز سكانها إلى جهات أخرى داخل القطر المصسري ، فقد أصدر الحسكم العسكري لمنطقة الصـحراء الغربيـة أمسراً عسكرياً بإخلائها من المدنيين () ، كما وافق مجلس الوزراء على مـا طلبه وزير الدفاع الوطني من تهجير ثلاثين ألفاً من البدو القاطنين في الجهة الواقعة بين العميد ويرج العرب إلى الداخل بداعي ضرورات الحرب ، وقد وافق مجلس الوزلاء أيضاً على اعتماد مبلغ خمسـة آلاف جنيه من اعتماد الطوارئ الخاصة للإففاق منه في تموين وإعاشة هؤلاء المهاجرين (؛) ، كما صدر أمر عسكري بإخلاء قرية الثط بمحافظة سيناء من سكانها والاستيلاء على مبانيها (•) وعلى أية حال فإن هذه المناطق التي ذكرناها هي التي كاتت أكثر من غيرها عرضسة لخطر الغارات الجوية ، وهي التي فرَّ منها سكانها بسبب هذه الغارات يلتمسون في هجرتهم

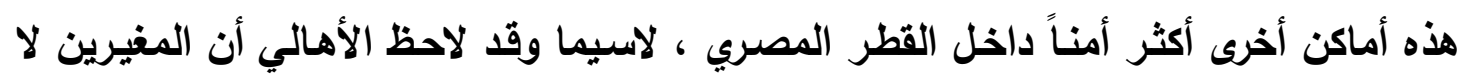

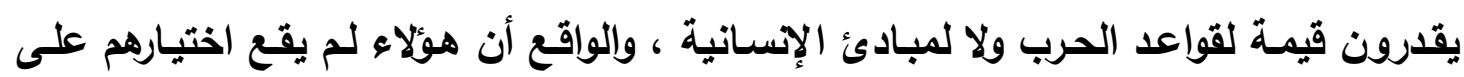
منطقة بعينها للإقامة فيها ، بل تشردواْ في كافة مديريات ومراكز وينادر وقرى القطر المصري، كلّ وفق حساباته الخاصة به ، ويلاحظ أن جمهور المهاجرين كان ينقسم إلى طبقتين : طبقة

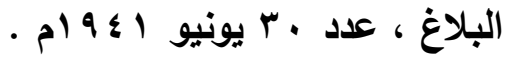

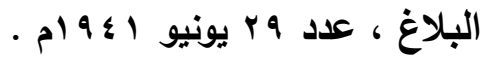

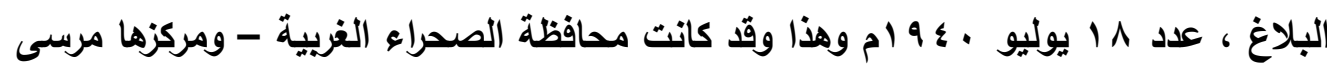

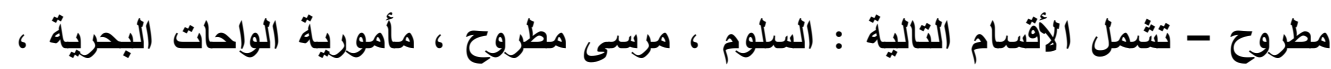

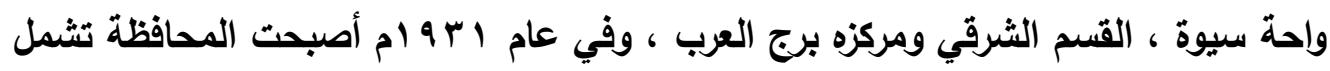

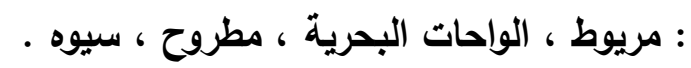

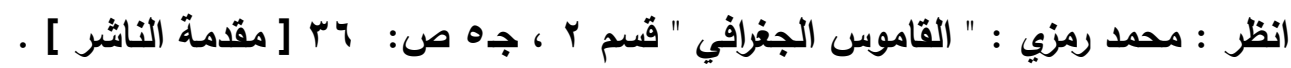

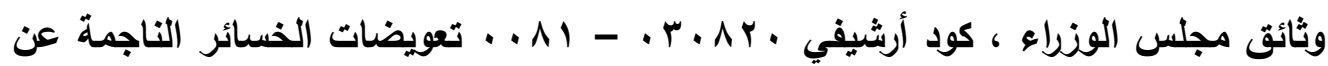

الغارات الجوية ، قرار لمجلس الوزراء بتاريخ اب يوليو ب \& 9 ام .

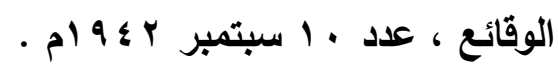


الموظفين وأصحاب الأعمال والمستخدمين والعمال الذين يزاولون أعمالاً دائمة ، وطبقة صغار أصحاب المهن والحرف وإلعمال والباعة الذين يعيشون من كسب بسيط غير مستقر إلى حدٍ ما

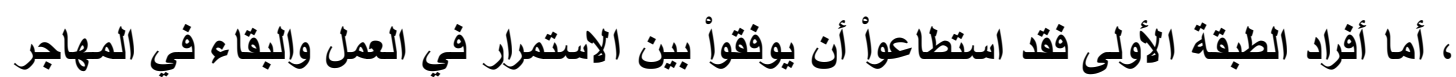

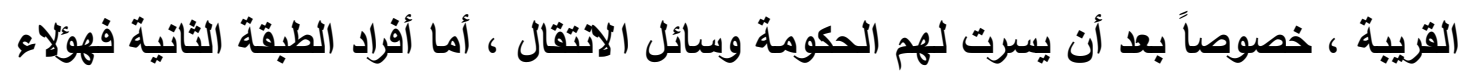

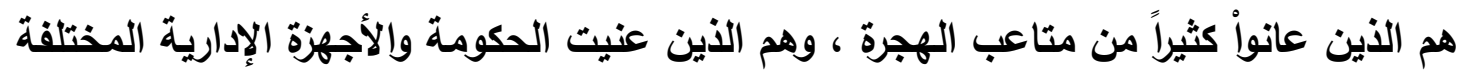

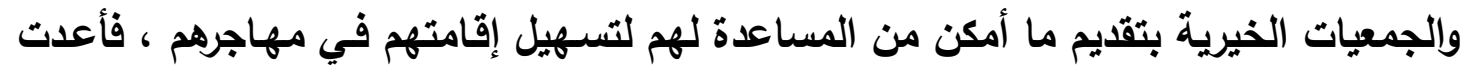

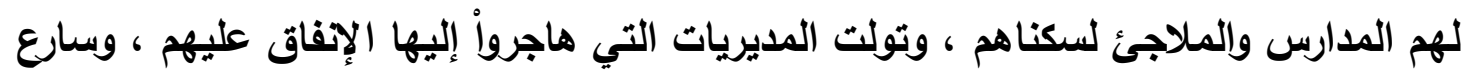

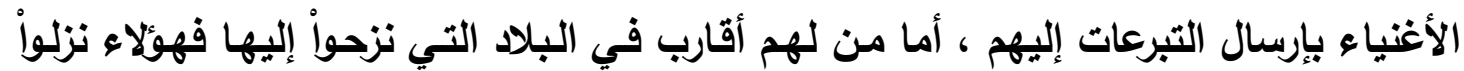

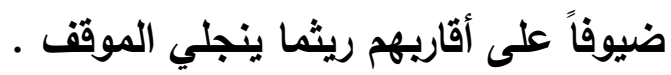
وأما الموسرون من المهاجرين فقد أعدت لهم السلطات في مهاجرهم التي اختاروها

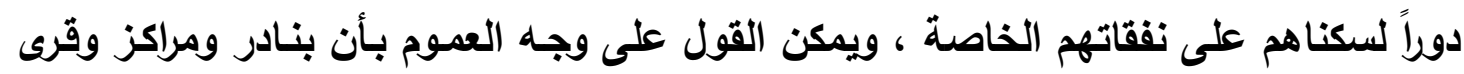

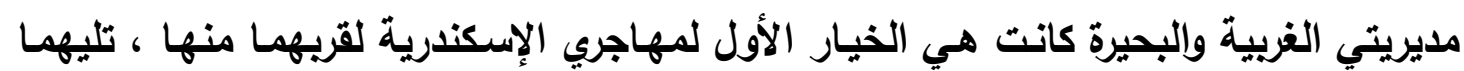

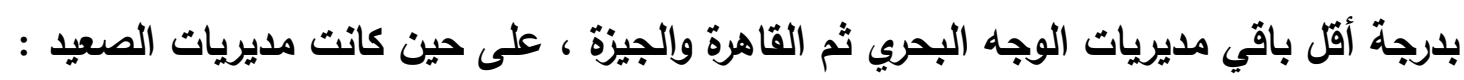

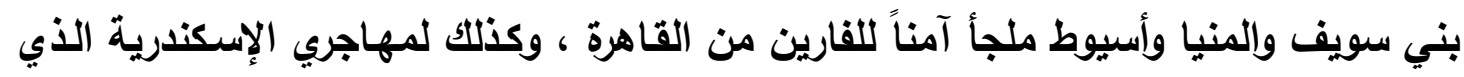

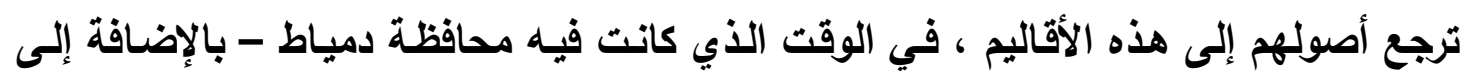

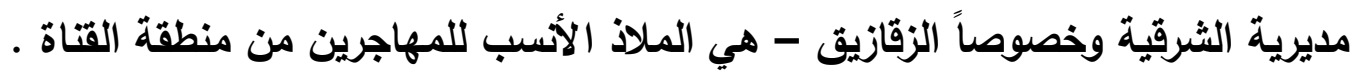

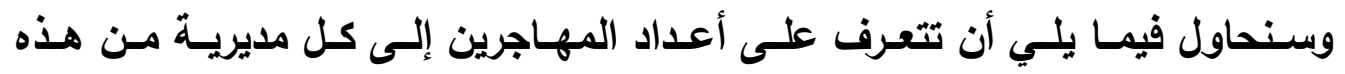

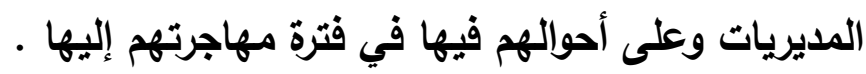
المهاجرون الي مديرية الغربية (') : كانت مديريـة الغربية من أكثر مديريات الوجه البحري اكتظاطاً بالمهاجرين ، ولهـا

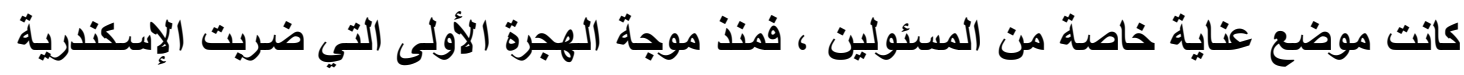

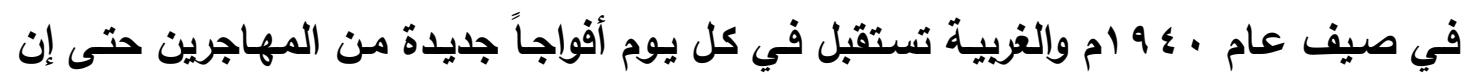

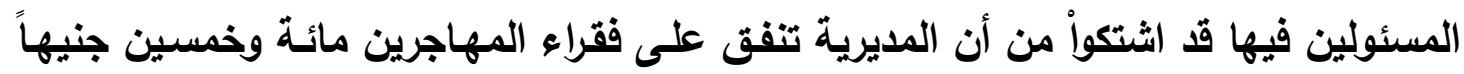

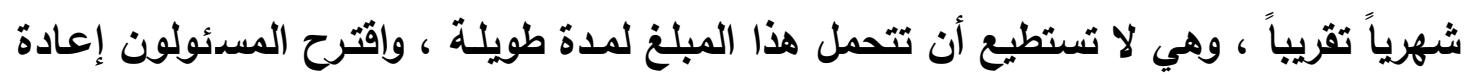

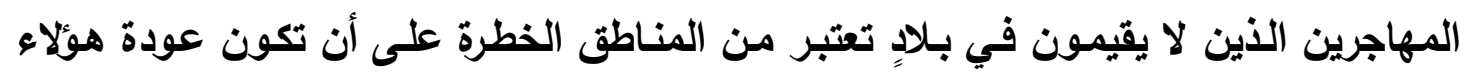

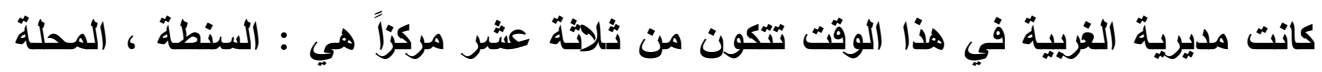

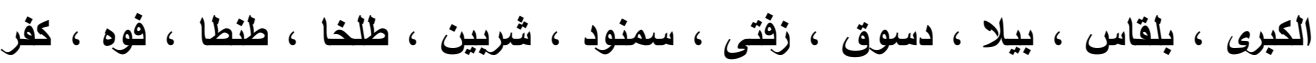

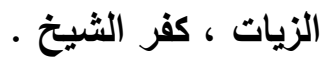

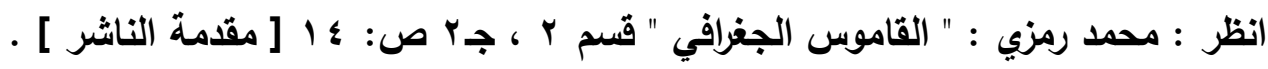


تدريجية (') ، بيد أن موجة الهجرة الثانية التي ضريت الإسكندرية صيف عام إ؛ 9 ام كانت

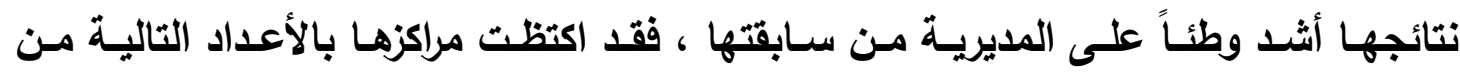

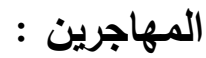

\section{جدول رقم (0) (0)}

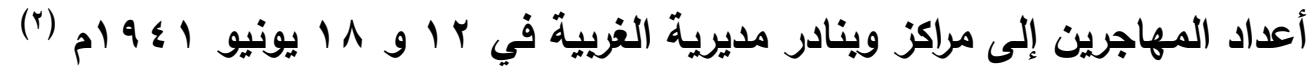

\begin{tabular}{|c|c|c|}
\hline \multicolumn{2}{|c|}{ عدد المهاجرين إليها } & \multirow{2}{*}{ الجهة } \\
\hline حتى 1 | يونيو | 9 ام & حتى Y ا يونيو 1 9 ام & \\
\hline$\Delta 0 \wedge \varepsilon$ & r l. & بندر طنطا ( قسم أول ) \\
\hline \&AIr & 1995 & 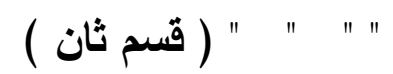 \\
\hline \& «TV & TVO & مركز طنطا \\
\hline 1.r. & 978 & بندر المحلة الكبرى \\
\hline $79 \varepsilon$ & TrV & مركز المحلة الكبرى \\
\hline rq. & $r \cdot 1 r$ & " " السنطه \\
\hline 901 & $\{r \mu$ & " " " سمنود \\
\hline VV17 & oroq & " " " الزيات \\
\hline rVVr & iv.. & " " زفتى \\
\hline $1 \wedge 994$ & vvi. & " " دسوق \\
\hline 7.7 & MI & " " شربين \\
\hline$\wedge 9$. & $0 .$. & " " " طلخا \\
\hline צ & Tro & " " " بيلا \\
\hline r119 & Tru & " " كفر الثيخ \\
\hline 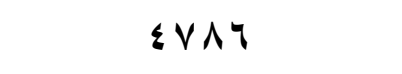 & $r V \leq r$ & " " " فوه \\
\hline $09 \leq 7 \leq$ & $r \wedge \leq \cdot V$ & المجموع \\
\hline
\end{tabular}

$$
\text { البلاغ ، عدد ؛ ا سبتمبر • ؛ } 9 \text { ام . }
$$

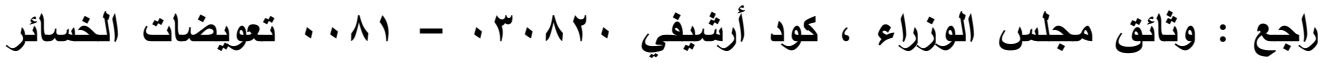

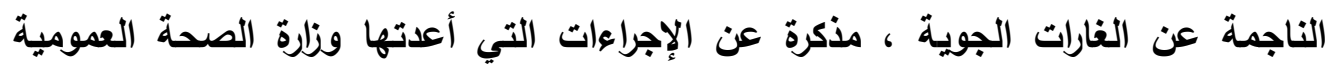

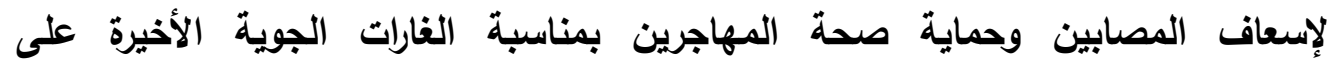

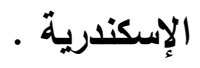

وإنظر كذلك : " البلاغ " عدد 1 ا يونيو 19 الإم . 
ومن هذا الجدول يتضح أن الجهات التي نزح إليها المهاجرون أكثر من غيرها : مركز

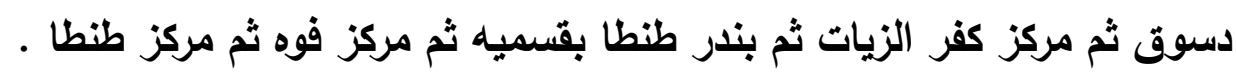

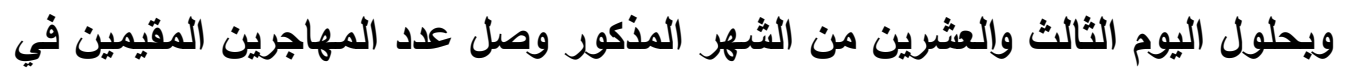

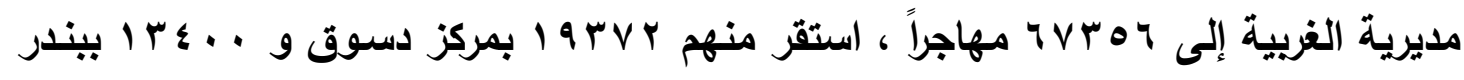

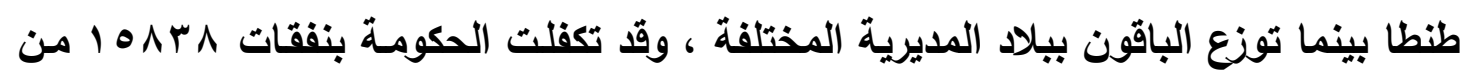

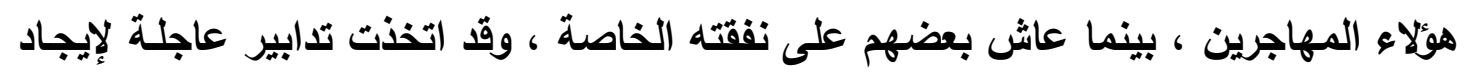

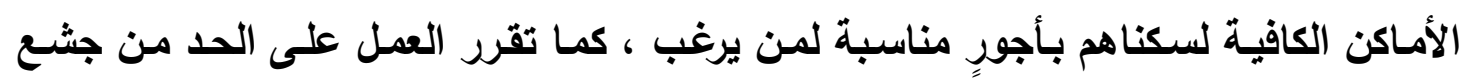

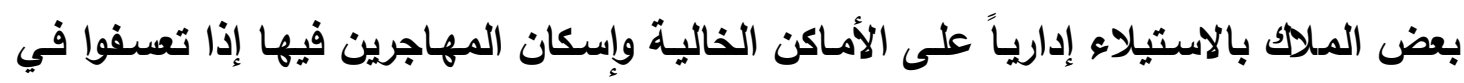

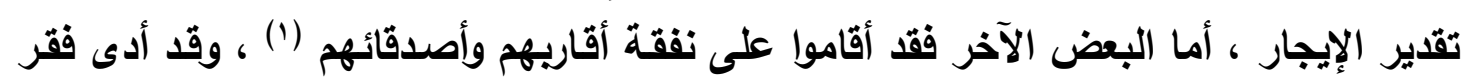

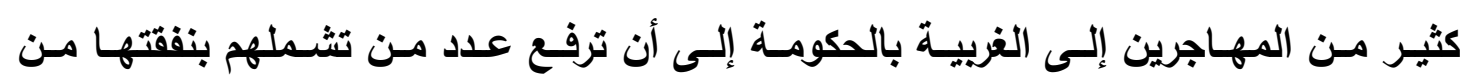

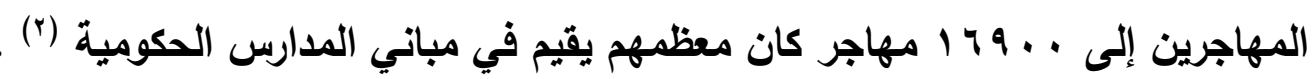

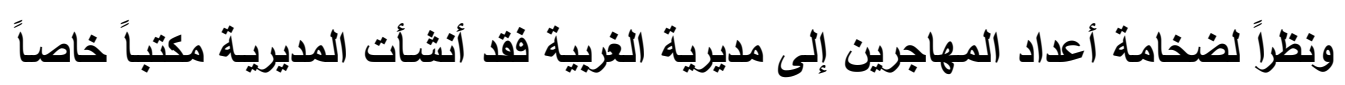

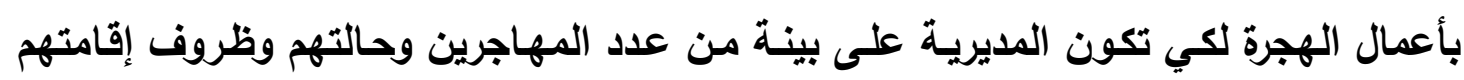

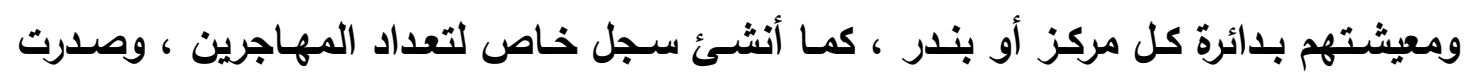

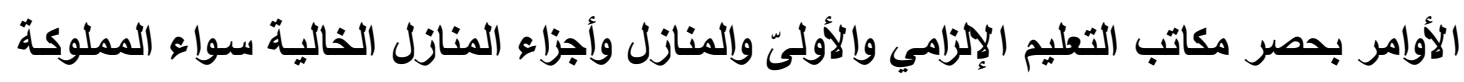

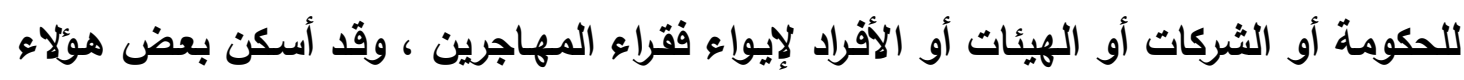

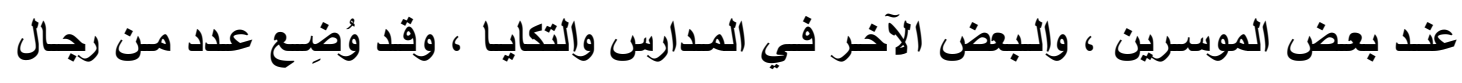

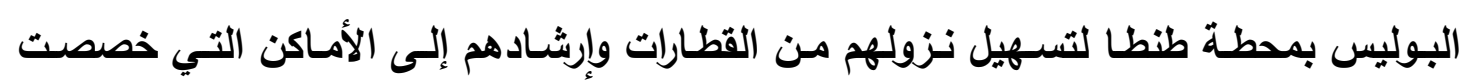

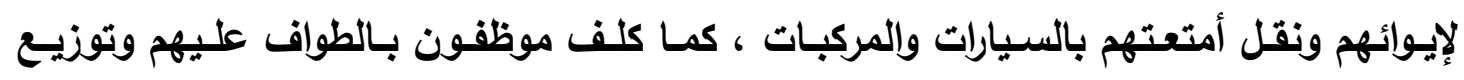

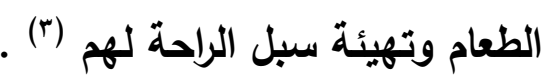
وقد تولى رجال البوليس مراقبة التجار مراقبة فعالة لمنعهم من رفع أثمان الحاجيات

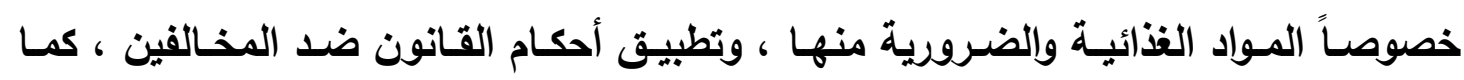

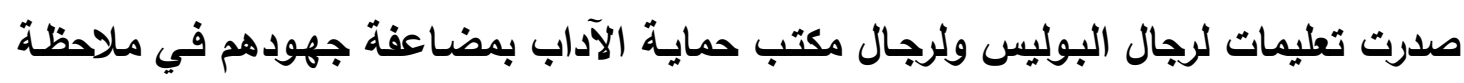

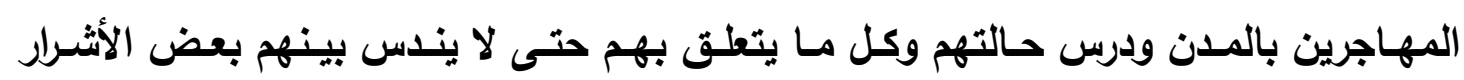

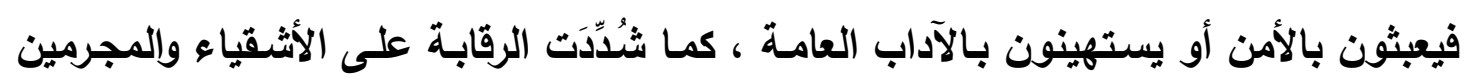

$$
\begin{aligned}
& \text { البلاغ ، عدد بץ يونيو إ؟9 ام . }
\end{aligned}
$$

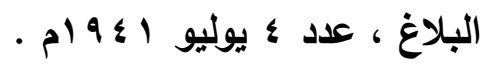

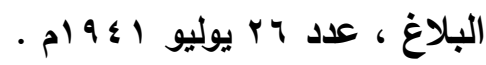


حتى لا ينتهزواً الفرصة فيزعجواً المهاجرين أو يعملواً على إفساد أخلاق بعضهم (') .

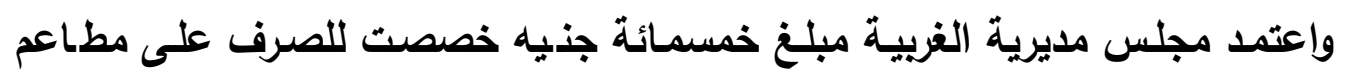

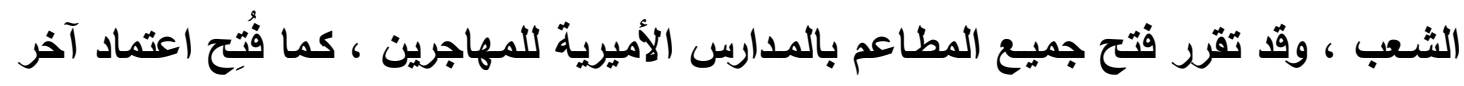

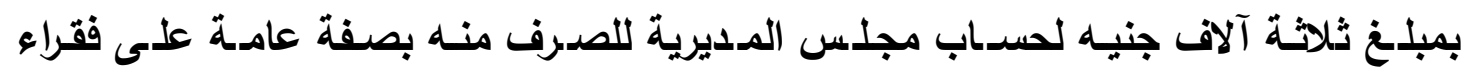

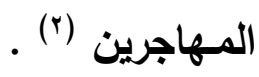
ويالنظر لقرب مدينة دسوق من الإسكندرية ولأن كثيرين من أهالي الإسكندرية قد

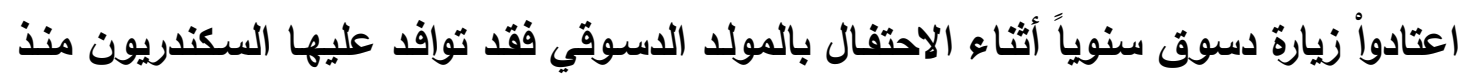

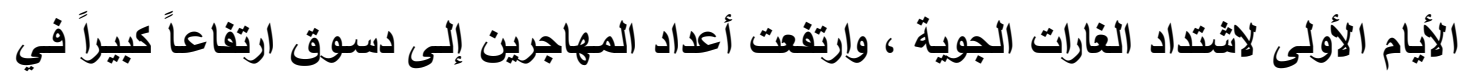

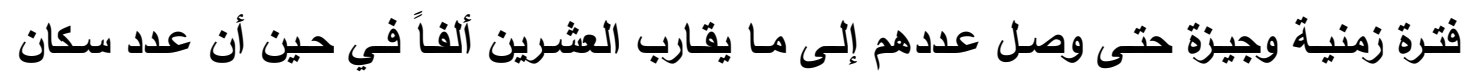

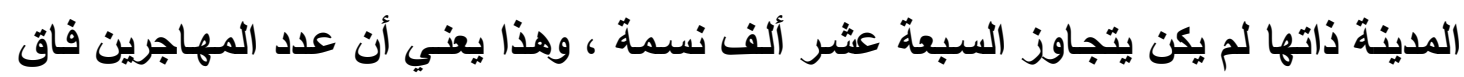

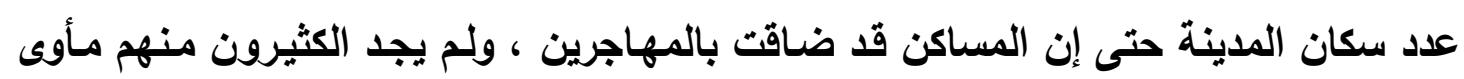

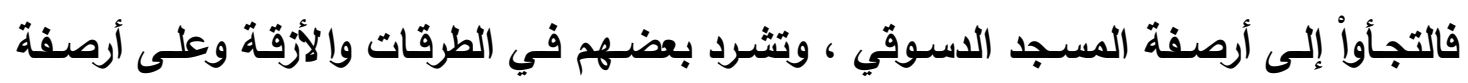

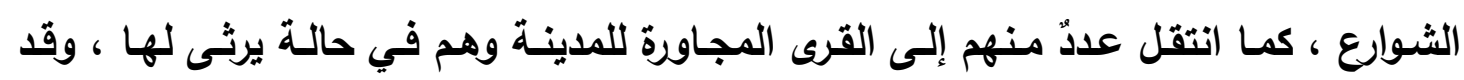

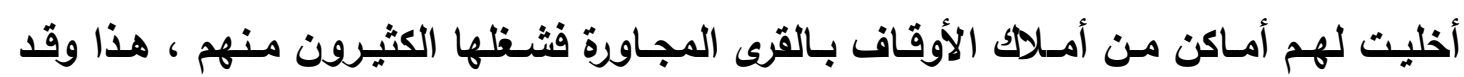

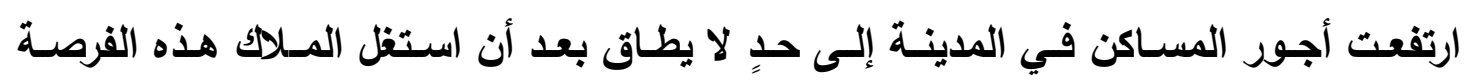

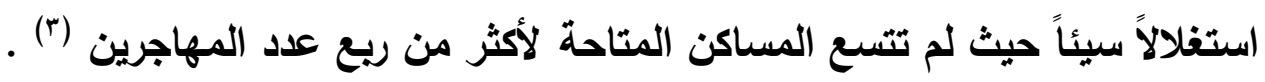

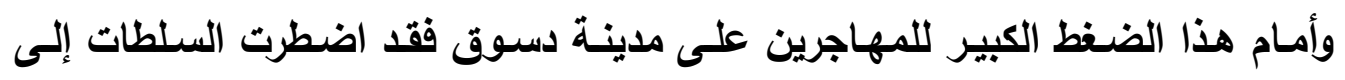

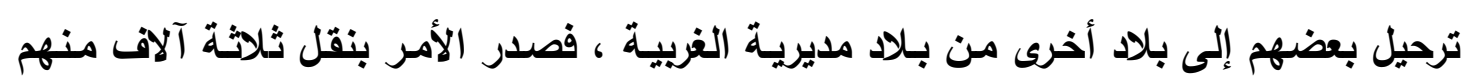

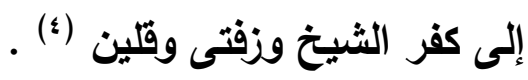
كما صدرت الأوامر بفتح بعض ولئ المدارس لإيواء اللاجئين ، ويدئ بالفعل بـإخلاء ثُلاث

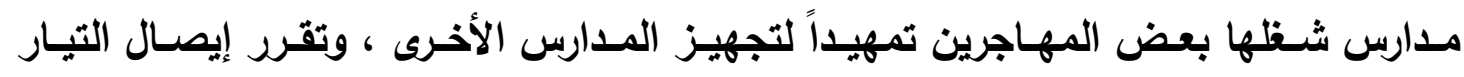

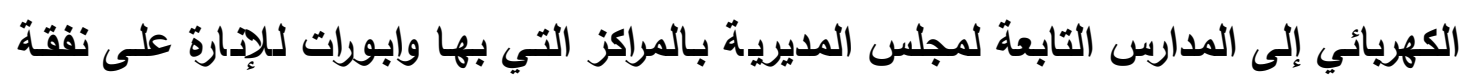

$$
\begin{aligned}
& \text { البلاغ ، عدد } 19 \text { يونيو إ؛ } 9 \text { ام . }
\end{aligned}
$$

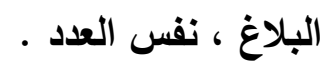

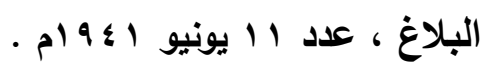

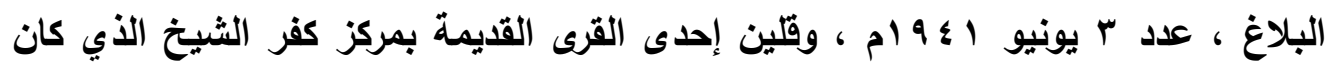

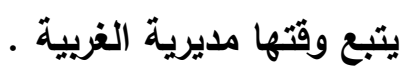

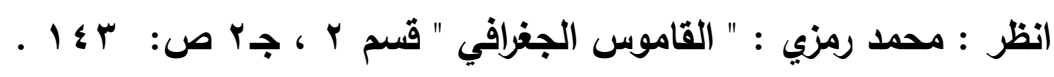


مجلس المديريـة (') ، كما طلبت المديريـة من الأزهر الثريف الموافقة على تسليم المعهـ

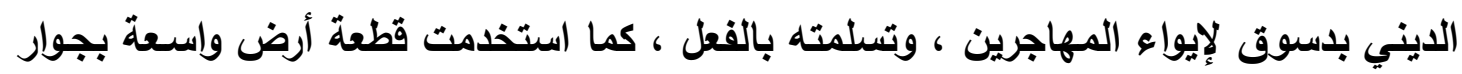

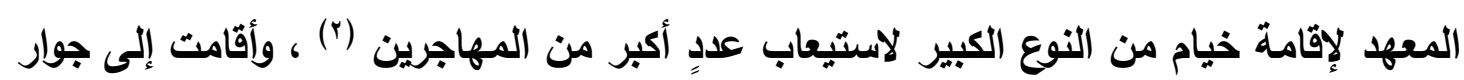

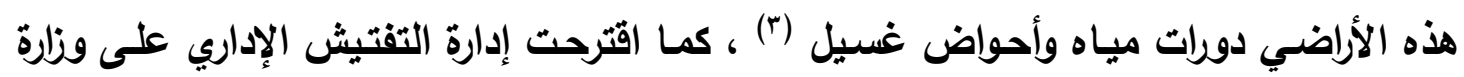

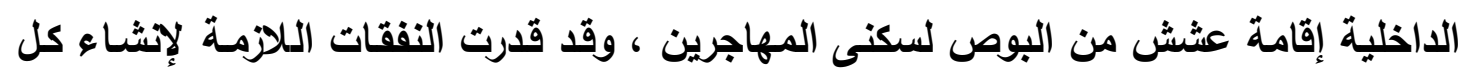

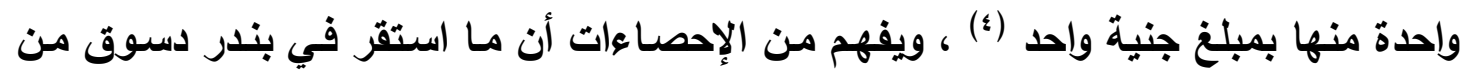

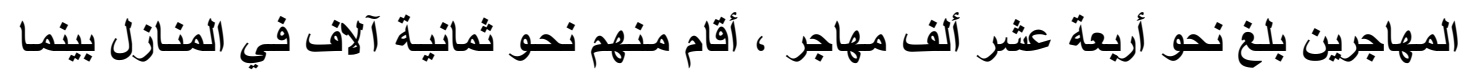

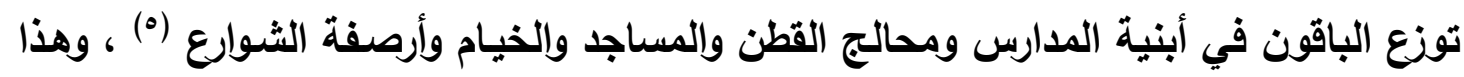

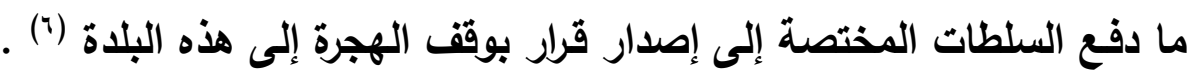

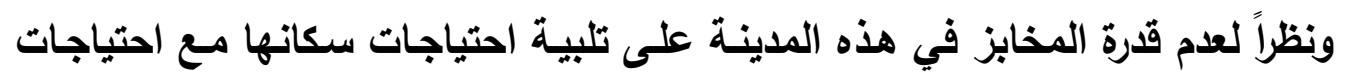

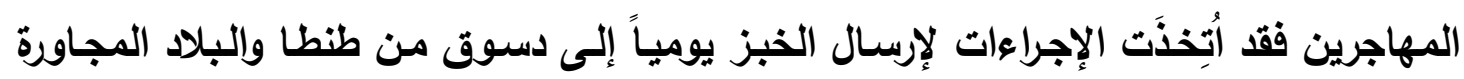

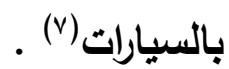

ورغم هذا الازدحام الثديد بالمهاجرين في جميع المنشآت في مدينة دسوق إلا أن

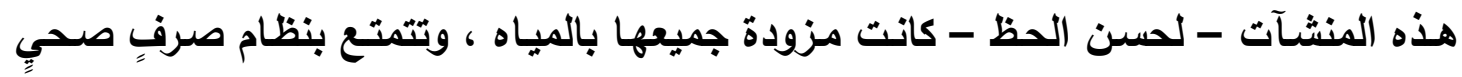

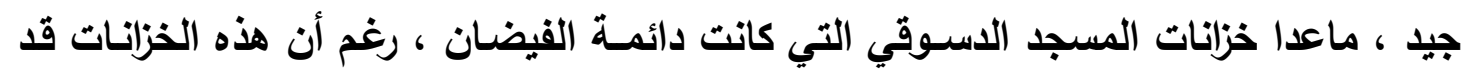

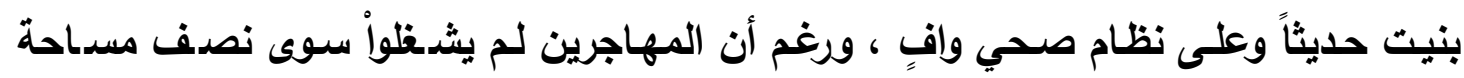

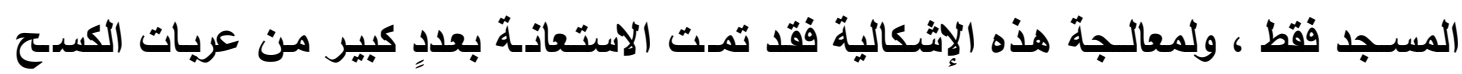

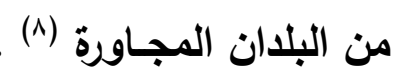

وقد حظى المهاجرون في دسوق باهتمام السلطات المحلية في المديريـة فزارهم مدير

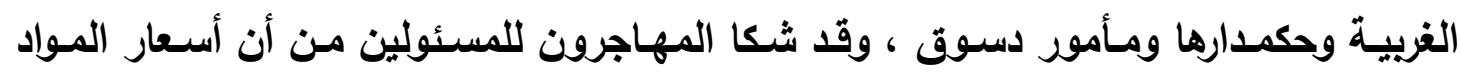

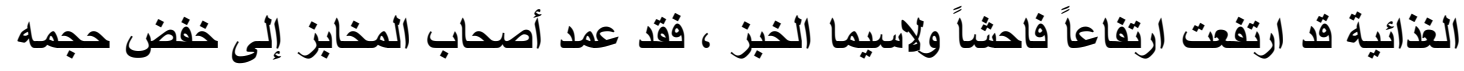

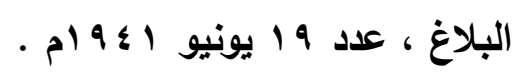

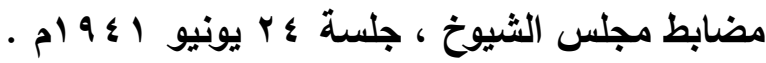

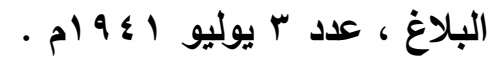

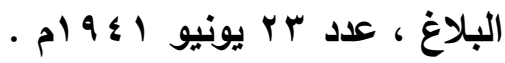

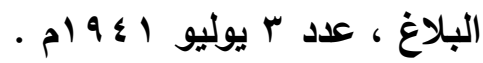

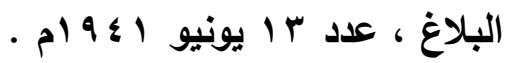

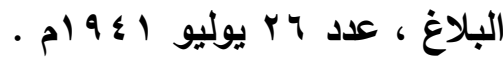

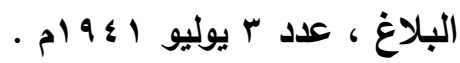


ومضاعفة سعره ، ووعد المسئولون بأنهم سيعالجون هذه المشكلة وسيضريون على أيدي

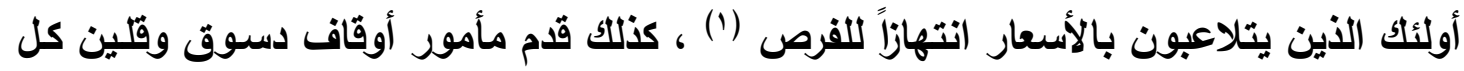

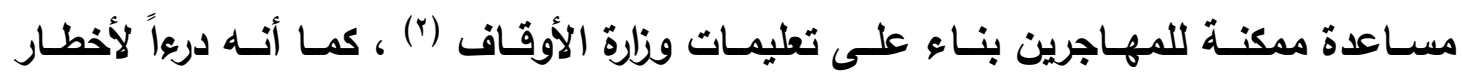
الأمراض ووقايةً منها أخذت الوحدات الصحية العديدة هناك في تطعيم المهاجرين بالأمصال ،

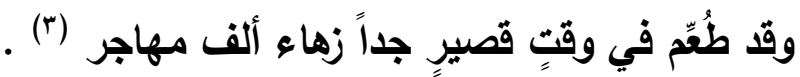
وفي طنطا بلغ عدد من وصل إليها من مهاجري الإسكندرية بطريق السكك الحديدية

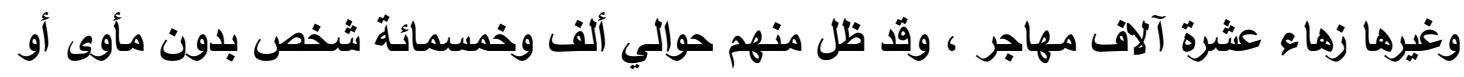

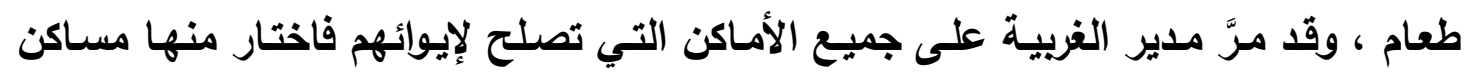

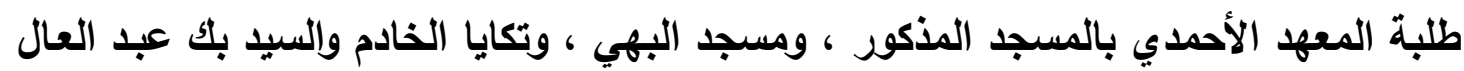

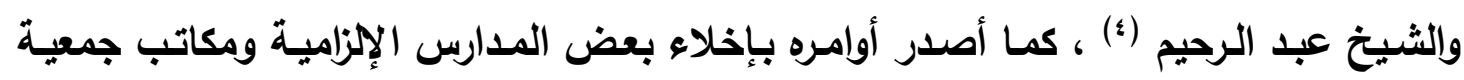

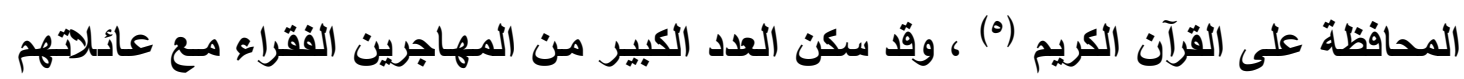

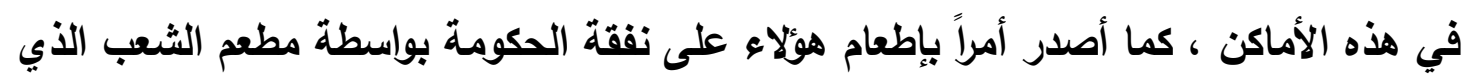

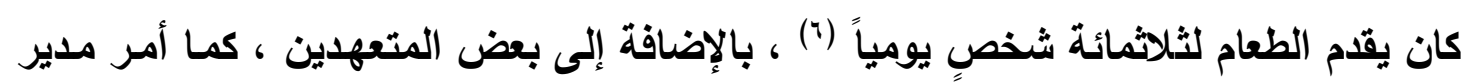

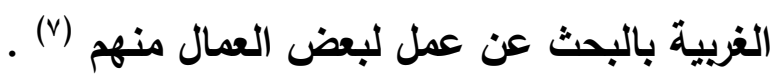

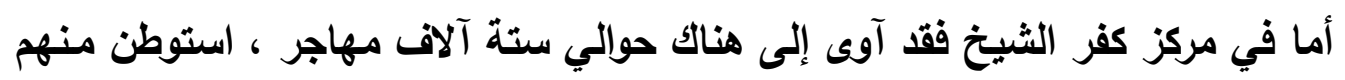
قرابة الألف في بندر كفر الثيخ بينما تفرق الباقون في قرى المركز ، وقد أنزلت السلطات

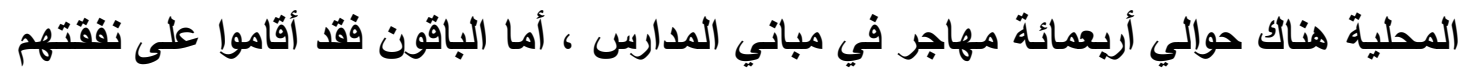

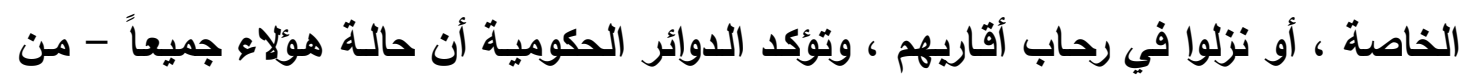

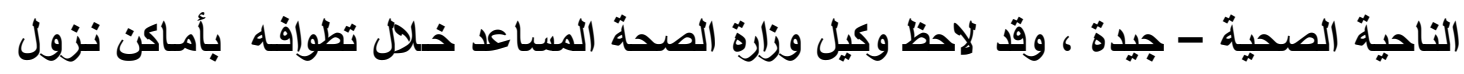

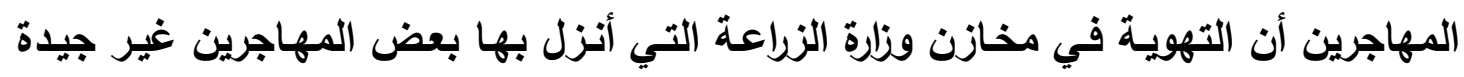

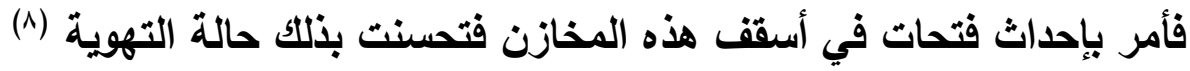

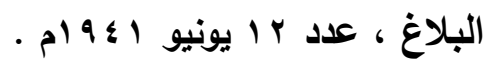

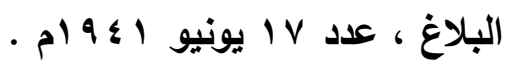

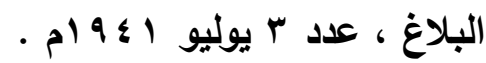

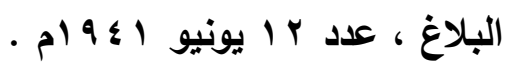

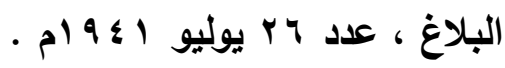

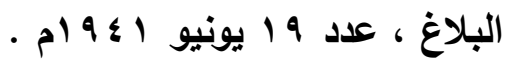

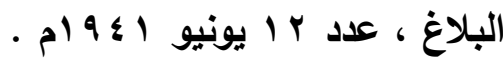

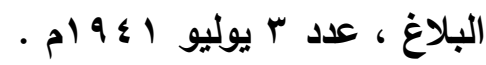


وفي مركز شربين الذي استوطنه حوالي الألف شخص من المهاجرين معظمه من

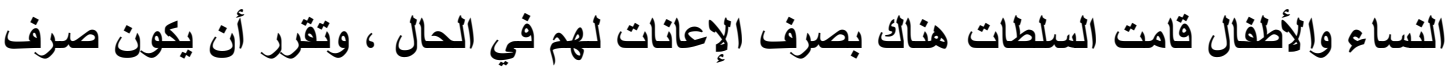

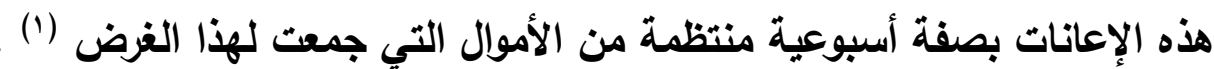
واكتظت مدينة المحلة الكبرى بالمهاجرين اكتظاظاً فاق كل تصور حتى صدارت الغرفة

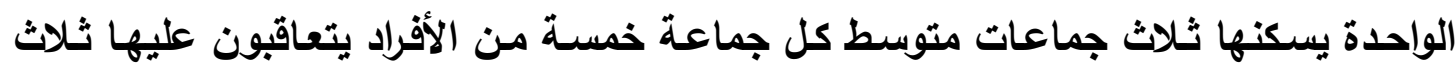

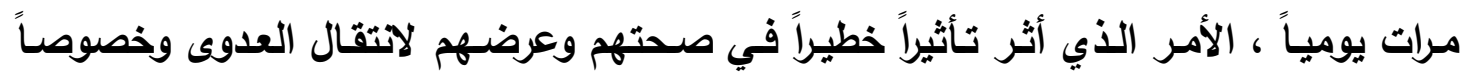

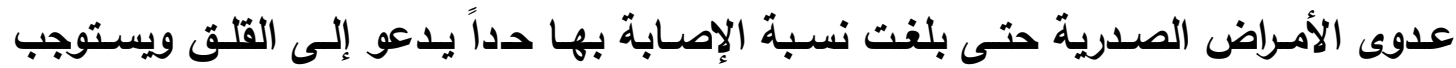

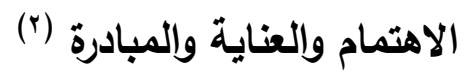

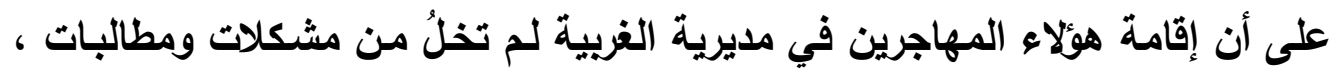
فقا اثتكى مهاجرو كفر الثيخ وفوه من سوء حالة الطريق الذي يربط بين الإسكندرية وهذه فئه

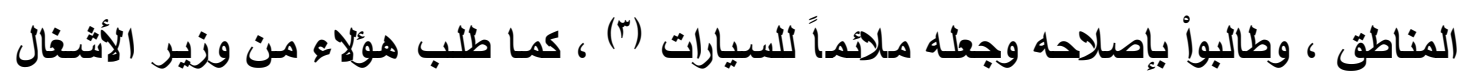

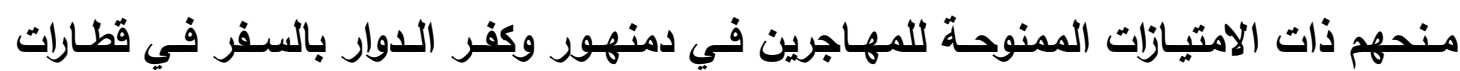
السكك الحديدية بأجورِ مخفضة ، وقد تلقت محافظة الإسكندرية شكاوي بهذا المعنى أيضاً ،

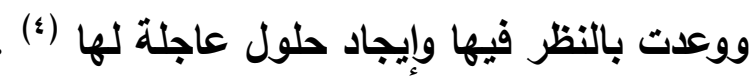
(०)

يُفهَم ممـا توفر من مصـادر هذه الفترة أن أكبر عددٍ من المهاجرين عقب حوادث

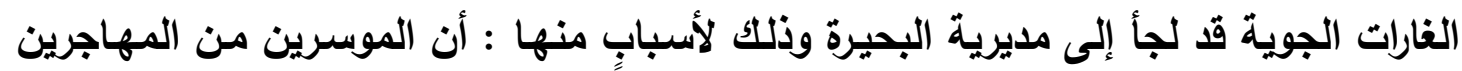

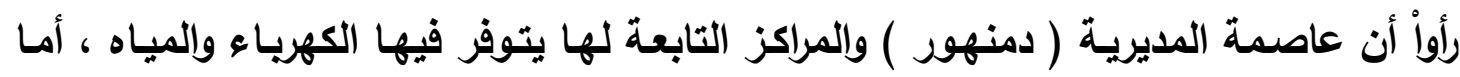
الفقراء فرأواً أنها مواطن قريبة من الإسكندرية يمكنهم الإقامـة فيها والاطمئنـان على أعمالهم

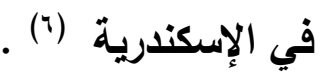

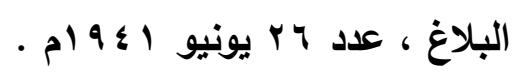

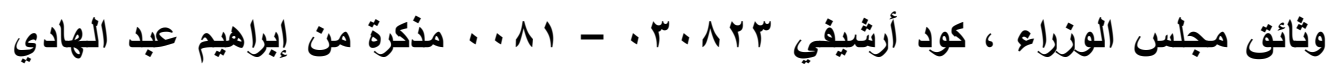

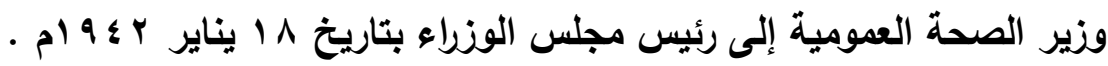

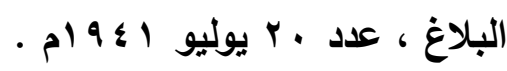

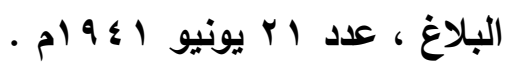

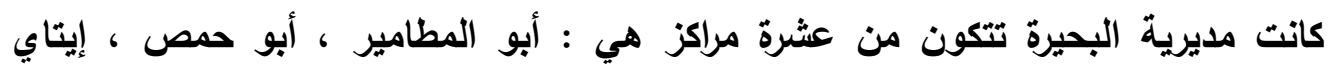

البارود ، اللالنجات ، المحمودية ، دمنهور ، رشيد ، شبراخيت ، كفر الدوار ، كوم حمادة .

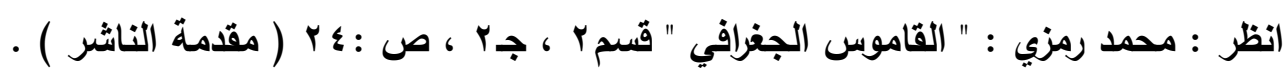

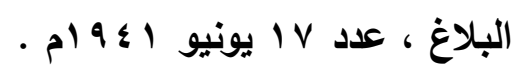




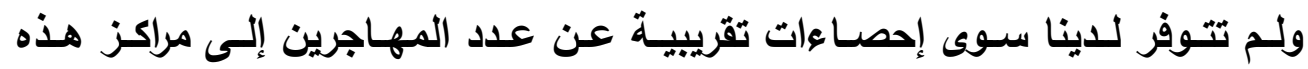

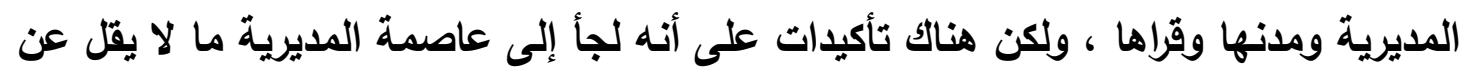

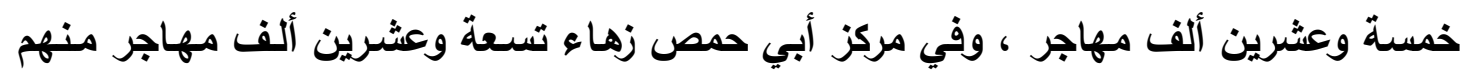

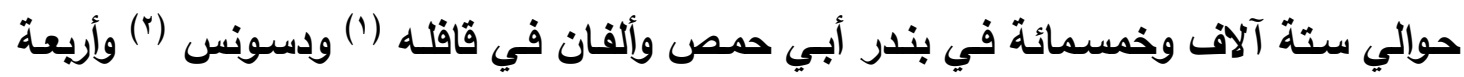
آلاف في بركة غطاس () ـ أما عدد المهاجرين في كفر الدوار فقد بلغ حوالي أريعة وعشرين ألفاً منهم زهاء عشرة آلاف في بندر كفر الدوار ، والباقون يتوزعون على قرى المراكز ويلداته الها

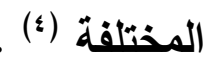

وفي وقتٍ مبكر من فترة تصاعد موجات الهجرة كان قد لجأ إلى مركز رشيد حوالي

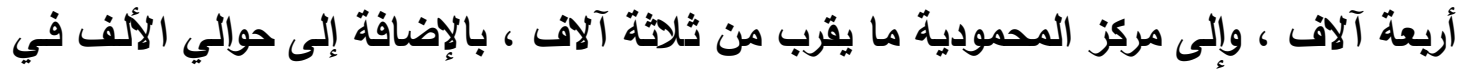

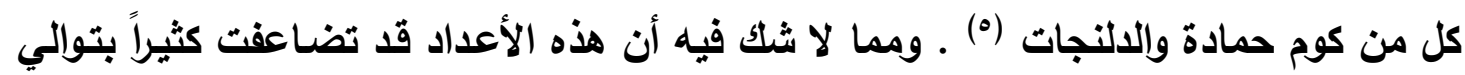

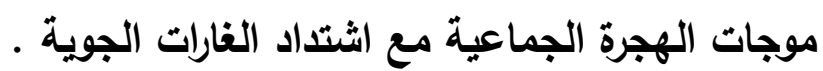

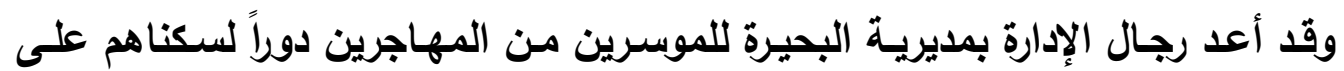

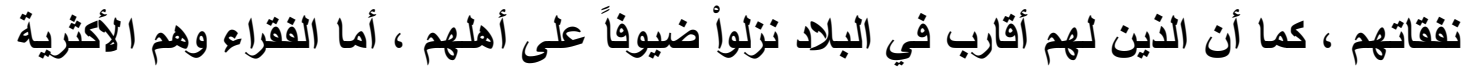

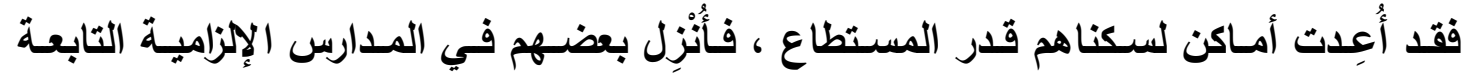

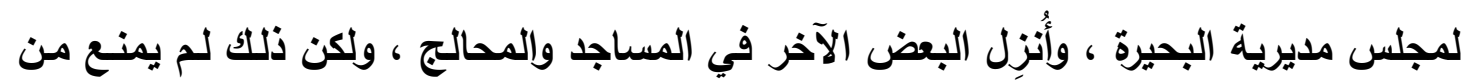

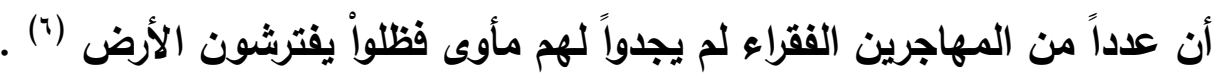

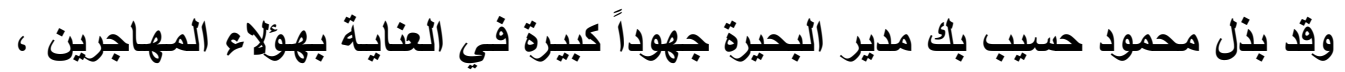
فأنثأ رجال إدارته أكثاكاً من الخشب في أفنية محالج الأقطان في بـلاد مديريـة البحيرة ليقيم

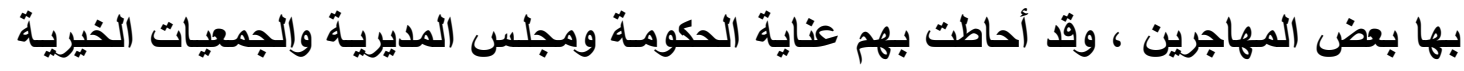

قافلة : قرية قديمة من قرى مركز أبو حص - محافظة البحيرة ، ذكرث في المصادر

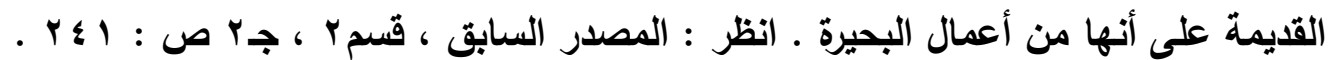

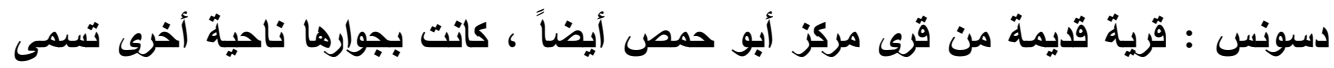
الحلفاية أضيفت إليها وصارتا ناحية واحدة باسم : دسونس الحلفاية ـ انظر : المصدر

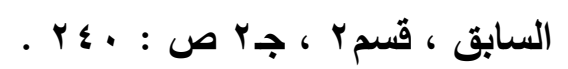
بركة غطاس : من قرى مركز أبو حمص القديمة كذلك ، اسمها الأصلي بركة فضال ثم

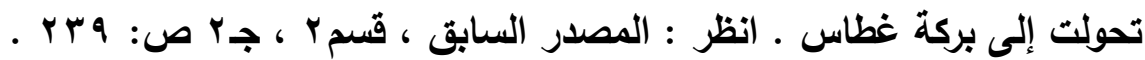

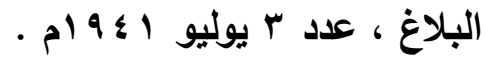

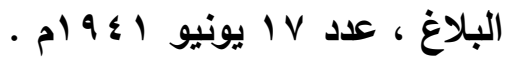

$$
\begin{aligned}
& \text { البلاغ : نفس العدد . }
\end{aligned}
$$


العامة التي دعا مدير البحيرة إلى الإسراع في تكوينها ، كما فُتِحَت أبواب المسـاجد وخُصِصت

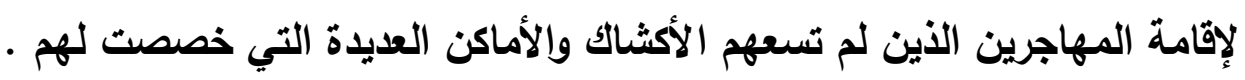

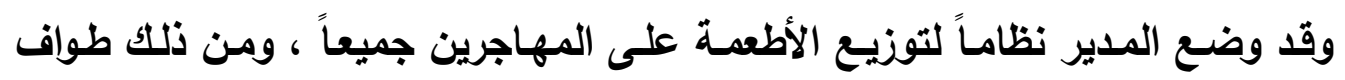
أعضاء جمعية المواسـاة التي أنشأها محمود بك في دمنهور على المهاجرين لتقديم الطعام لهم ، وكذلك طواف الوحدات الصحية عليهم بين وقت وآخر للعنايـة بصحتهم وصرف الأدوية لهج بالمجان كما سارع الأثرياء بإرسال التبرعات إليهم (') . وقد كانت مدينة دمنهور إحدى المدن التي هاجر إليها سكان الإسكندرية بغزارة لقريها من ناحية ولتوفر وسائل المواصلات إليها من ناحية أخرى ، ولما كانت هذه المدينة قد امتلأت بالسكان فقد رؤي الاكتفاء بهذا العدد الكبير الذي وصل إليها من المهاجرين ، وتقرر منع الهجرة إليها ، وطلبـ السـلطات المختصـة إلى السكتك الحديليـة عدم إرسـال قطارات خاصـة

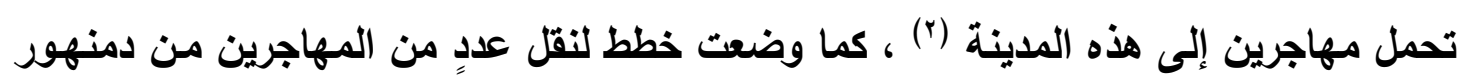

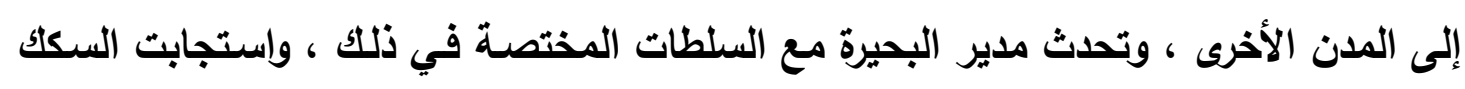
الحديدية فسيرث قطاراً خاصاً لنقل عددٍ من هؤلاء المهاجرين إلى إيتاي البارود ـ ومن المثير للاهشة أن مصلحة السكك الحليدية قا سيرت ثلاثة قطارات أخرى تحمل بعض المهاجرين من من هن دمنهور إلى دسوق التي كاتت تعاني بدورها اكتظاظاً شديداً بالمهاجرين (r) . ولا يوجد إحصاء دقيق لعدد الذين أقامواْ في منازل استأجروها ولا لعدد الذين نزلواً عند أقاربهم في دمنهور ، وكل مـا أمكن حصره هو عدد الذين شملتهم الحكومـة برعايتها وهؤلاء بلغواً حوالي ستة آلاف شخص ، وقد تفقد مسئولو وزارة الصحة حالتهم الصحية وتبين أنها جيدة في مجملها على الرغم من ازدحام محالّ إقامتهم ، وقد طعدت الوحدات الصحية بالأمصال ضد الأمراض ما يقرب من ألفين ومائتين من هؤلاء في فترة وجيزة (؛) .

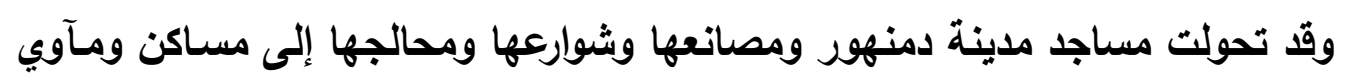
للمهاجرين والمنكويين ممن غدرت بهم الغارات الجوية ، وكاتت بيوت الله مضافاً للجميع ، فقد نزل بجامع التوبة عدد كبيرٌ من اللاجئين ، ومثله جامع الحبشي ، كما استضاف ملجأ جمعية البر والتقوى نحو مائة لاجئ ، كما تحول محلج الثيخ سعيد يونس إلى مأوى للمنكويين حيث

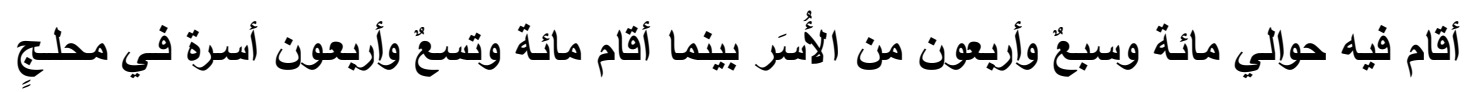

$$
\begin{aligned}
& \text { البلاغ ، عدد ؟1 يونيو 1 أو ام . }
\end{aligned}
$$

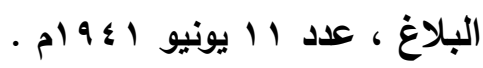

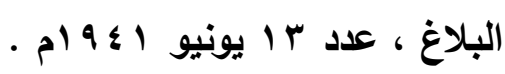

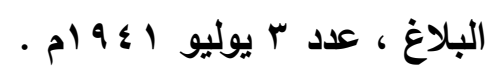


آخر ، في الوقت الذي امتلأ فيه محلج يملكه الوكيل باثـا بعدد من اللاجئين يفوق ما كان في

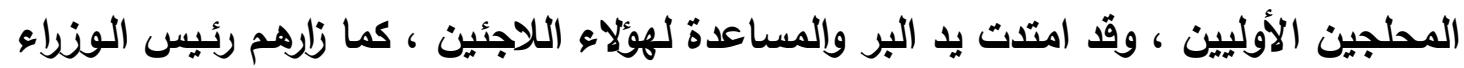
وتفقد حالتهم واستمع إلى مطالبهم وشكاواهم (1) .

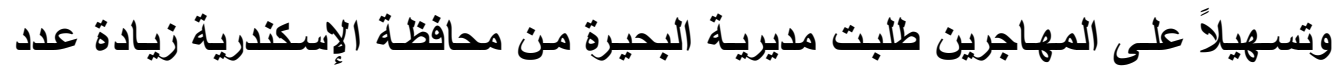

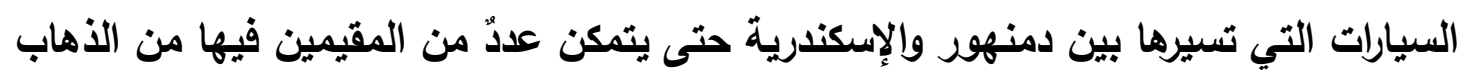

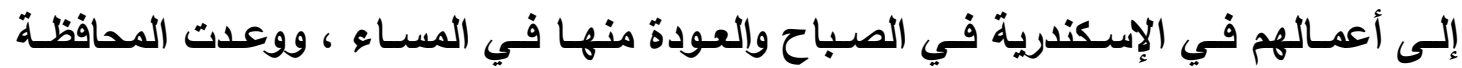

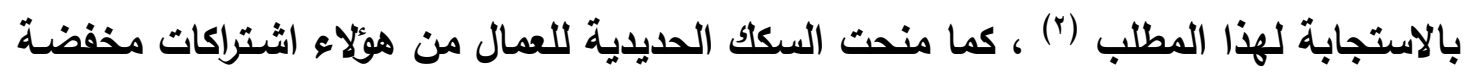

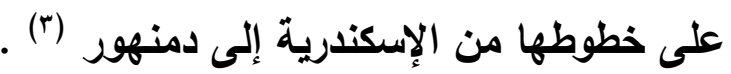

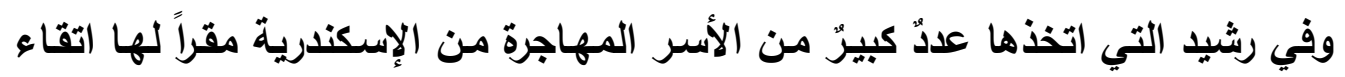

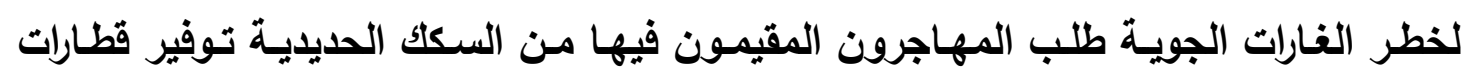

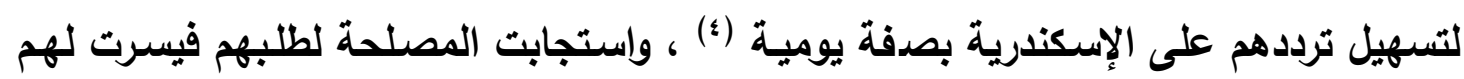

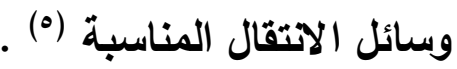
أما في إدكو التابعة لرشيد فقد قرر قسم التموين في محافظة الإسكندرية أن يرسل

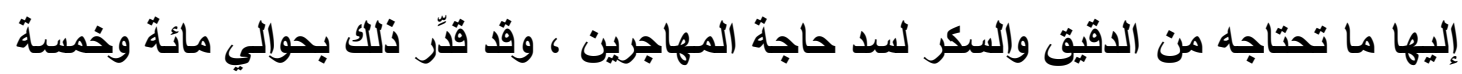

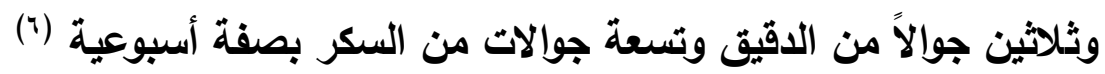

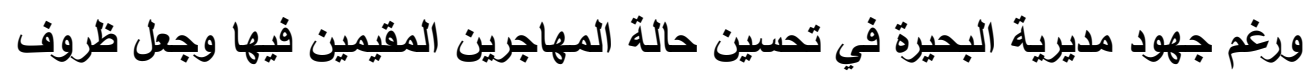

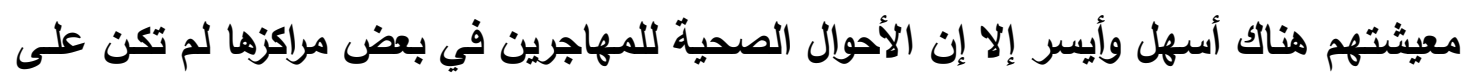
ما يرام ، فرغم ضخامة عدد المهاجرين في مركز كفر الدوار ورغم اهتمام السلطات المحلية

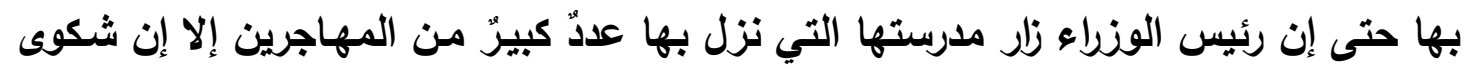

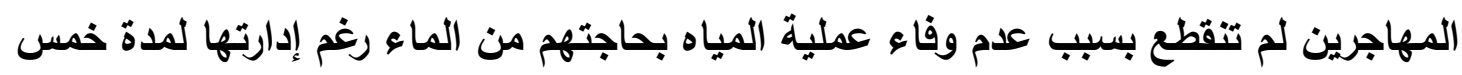

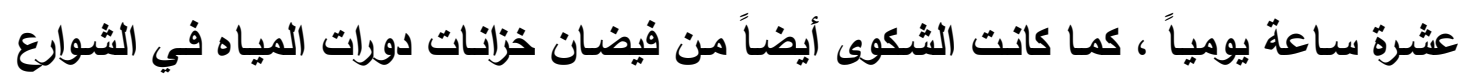

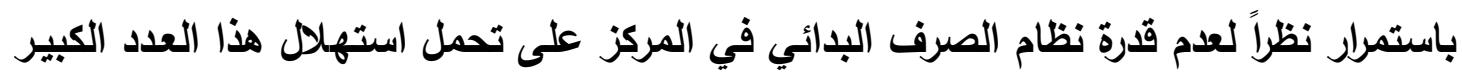

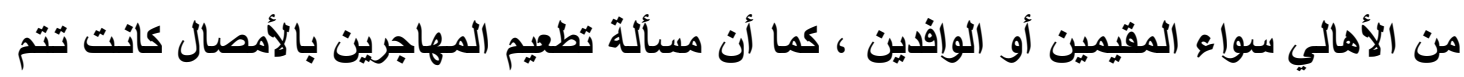

$$
\begin{aligned}
& \text { البلاغ ، عدد ·r يونيو 1؛ } 9 \text { ام . }
\end{aligned}
$$

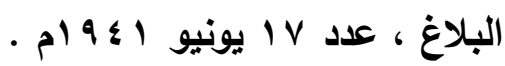

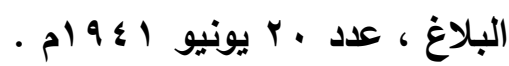

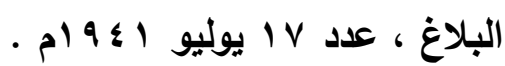

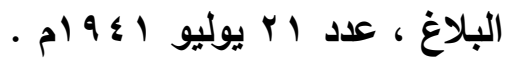

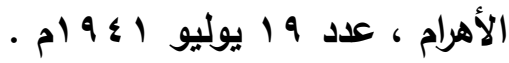


ببطء شديد وإن كان السبب في ذلك يرجع إلى المهاجرين أنفسهم الذين كانواً يرفضون التطعيم

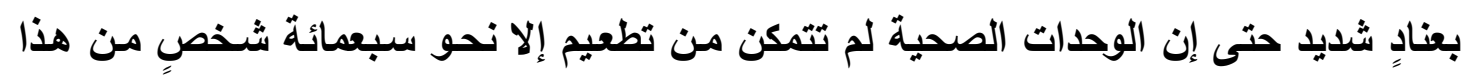

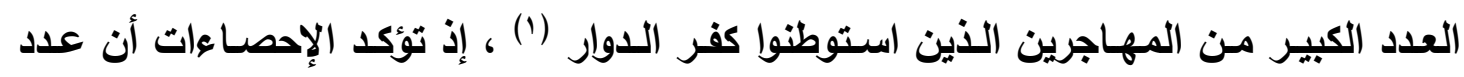

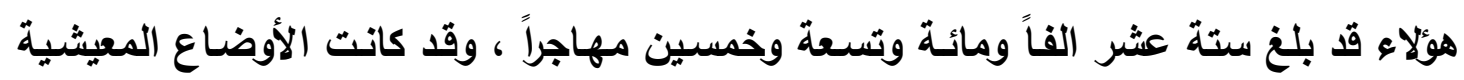

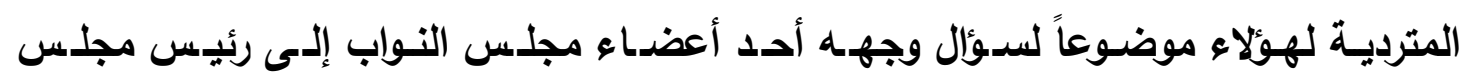

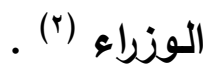

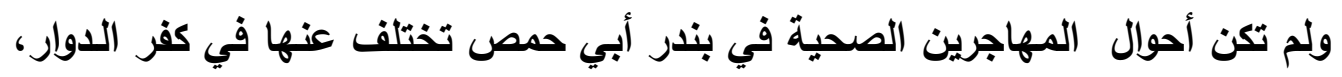

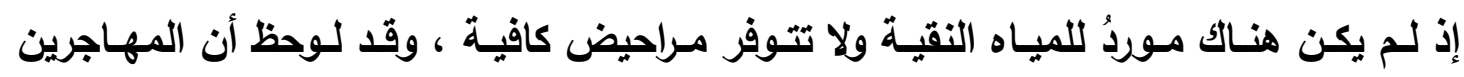

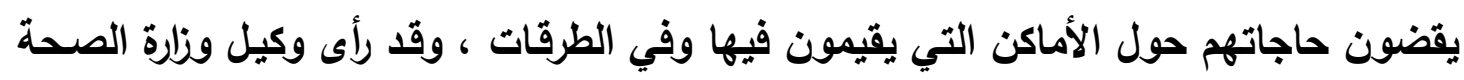

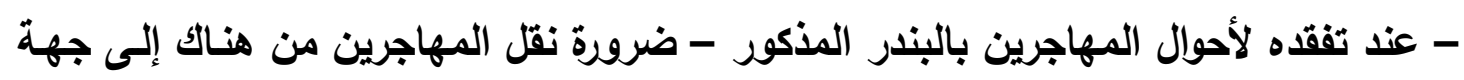

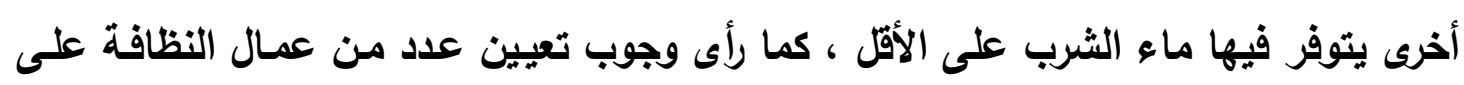

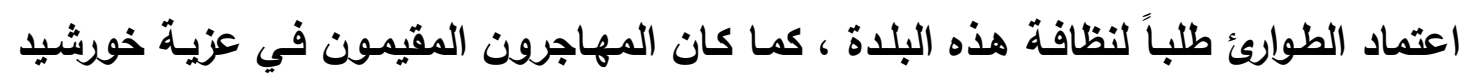

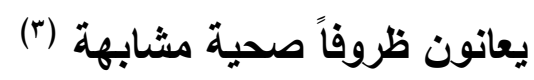

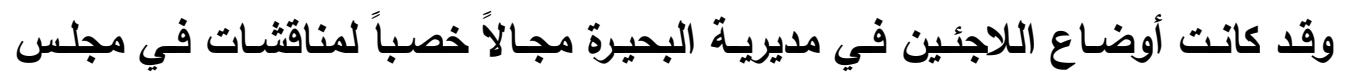

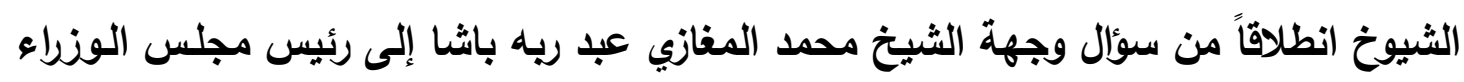

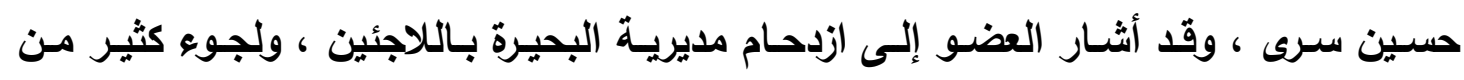

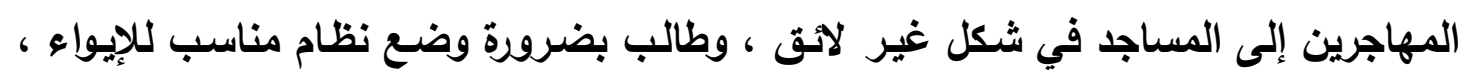

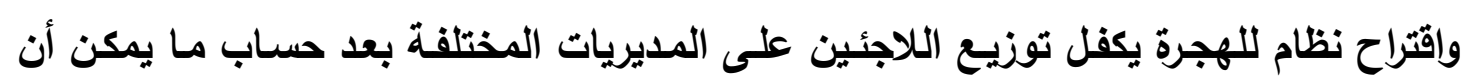

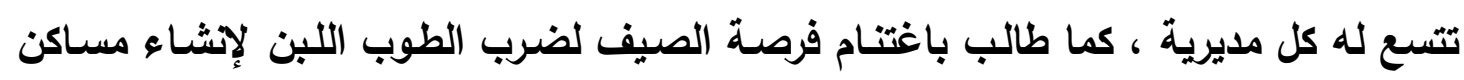

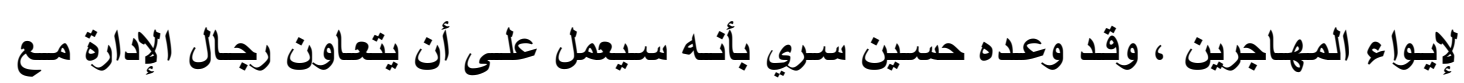

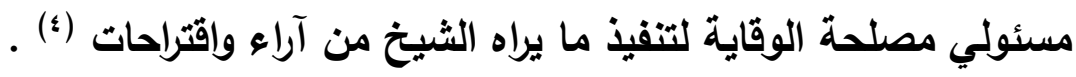

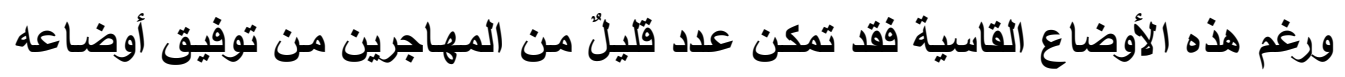

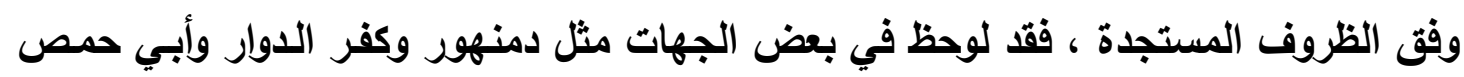

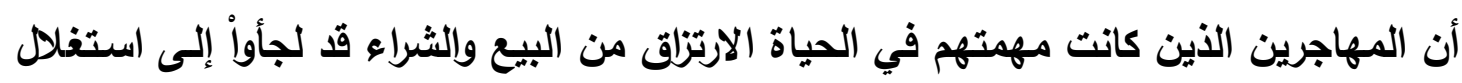

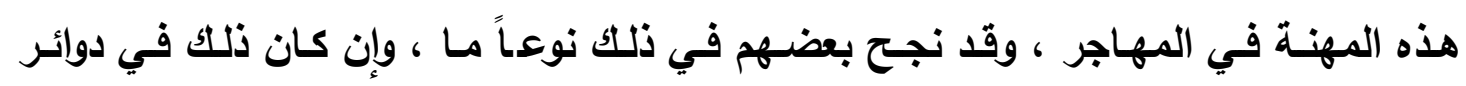

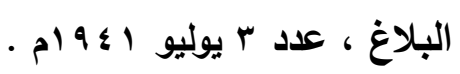

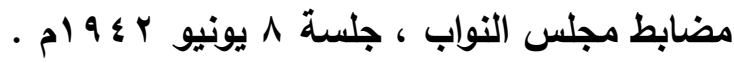

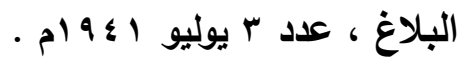

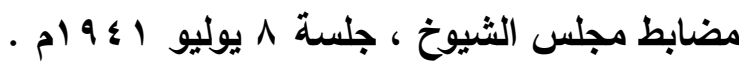




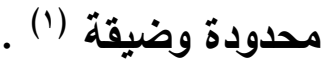

المهاجرون الي مديرية المنوفية :

قدم كثيرٌ من مهاجري الإسكندرية إلى مديرية المنوفية حيث استقر بعضهم في مركز

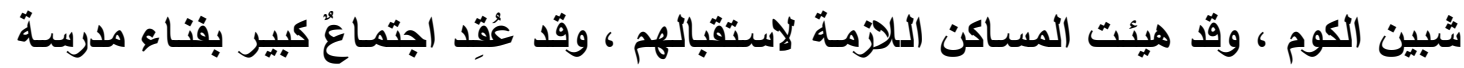

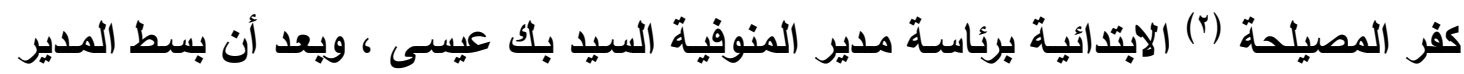

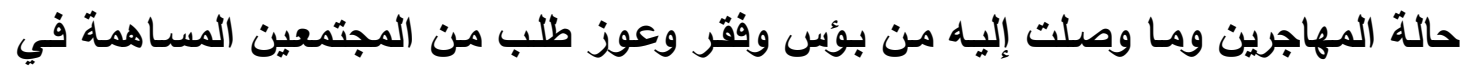

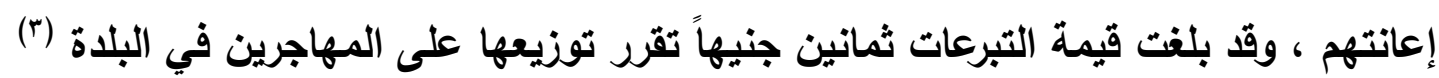

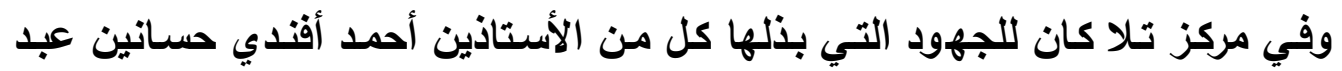

الغفار المدرس بمدرسة المساعي المشكورة وشقيقه مصطفى الموظف بالمحكمة الأهلية أثرها

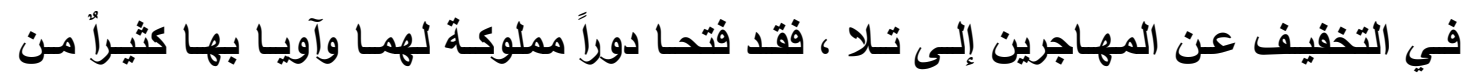
المهاجرين وقدما لهما ما يحتاجانه من مطعم وملبس ، كما عمل مأمور المركز على تنظيم

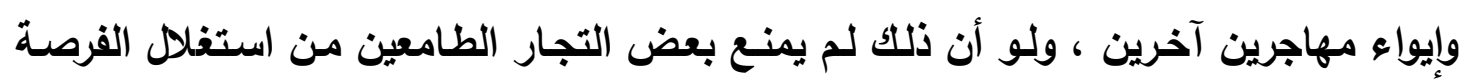

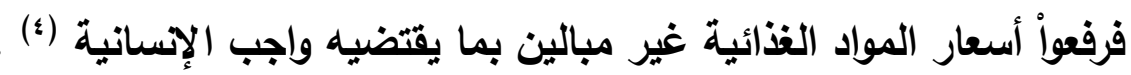

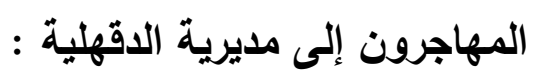

قدمت إلى المنصورة جموع غفيرة من مهاجري الإسكندرية ، وقث استقر من هؤلاء نحو

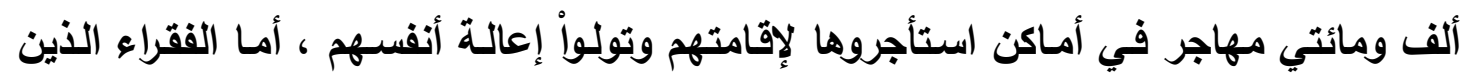

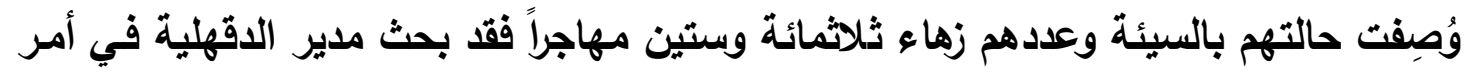

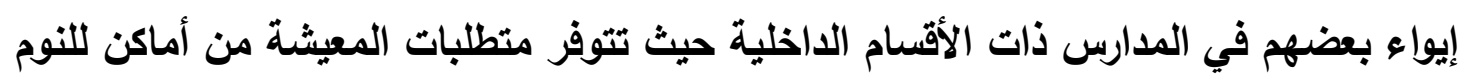

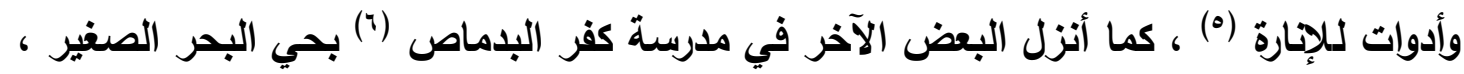

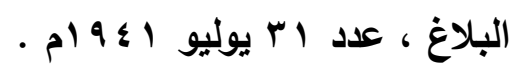

كفر المصيلحة : من قرى مركز شبين الكوم - محافظة المنوفية ، أصله من توابع ناحية

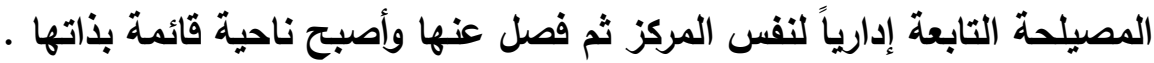

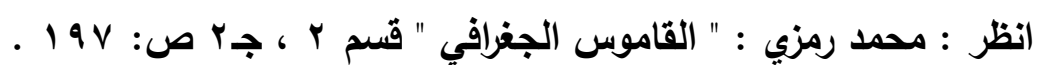

$$
\begin{aligned}
& \text { البلاغ ، عدد VI يونيو إ } 9 \text { ام . }
\end{aligned}
$$

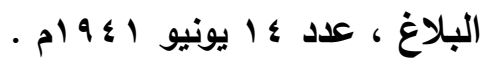

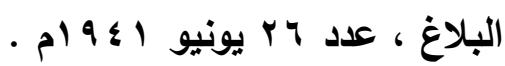

كفر البدماص : إحدى القرى القديمة التي كانت تابعة لمركز المنصورة ، محافظة الدقهلية ،

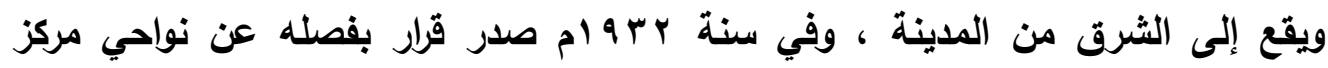

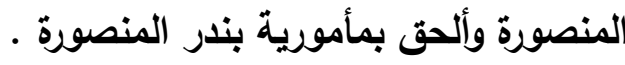


وقد كُلِّف أحد المتعهدين بتوريد الطعام لهم على حساب اللجنة التي شكلت للعناية بهم برئاسة

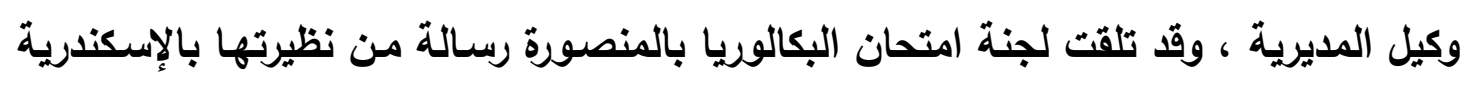

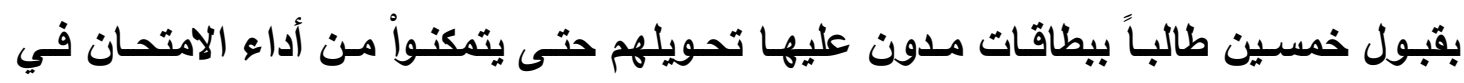

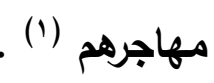

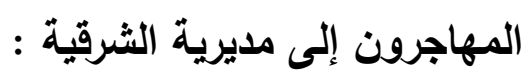

بلغ عدد المهاجرين في مديرية الثرقية أكثر من ستة آلاف مهاجر تفرقواً في بـلاد

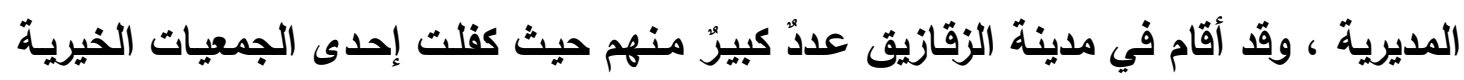

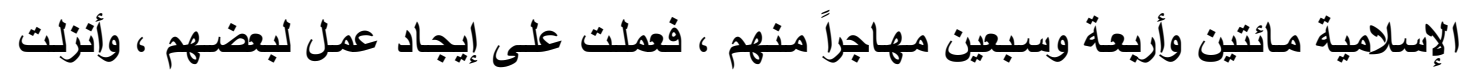

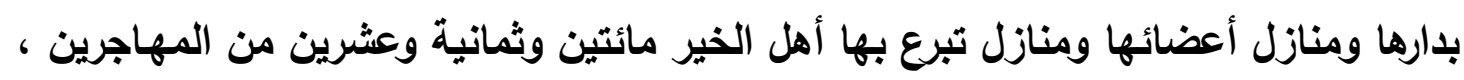

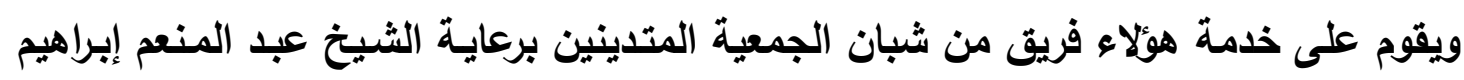

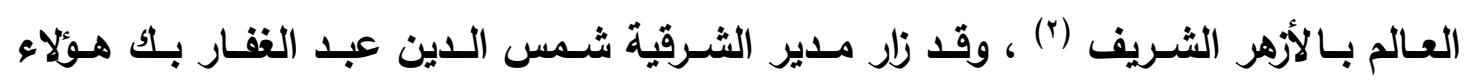

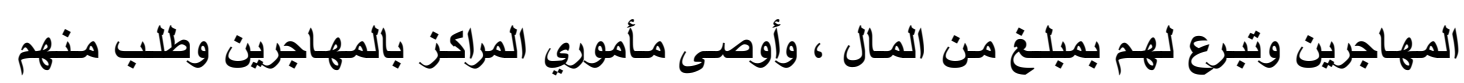

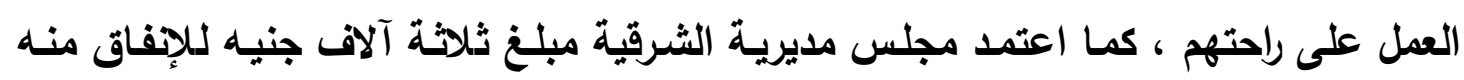

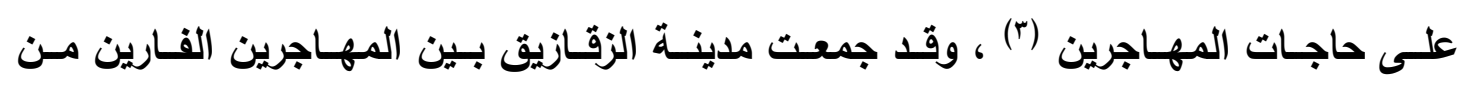
الإسكندرية والنازحين من منطقة القتاة المهاجرون إلى مديرية القليوبية :

وصل إلى مديريـة القليوبيـة حوالي ألف وثمـانين مهاجراً اسدتقر معظمهم في مدينة

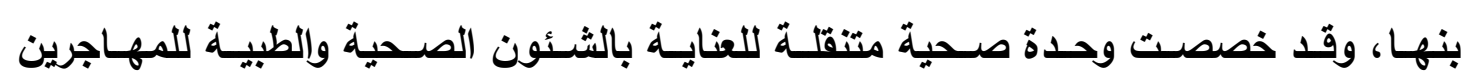

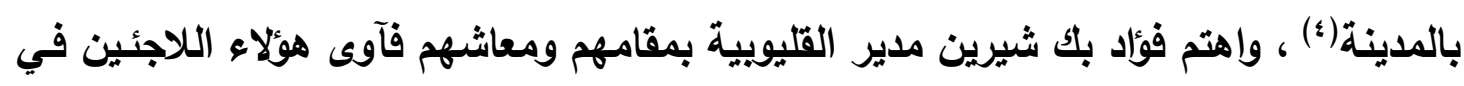

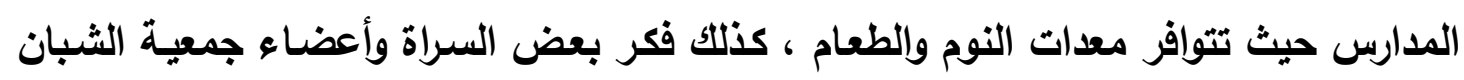

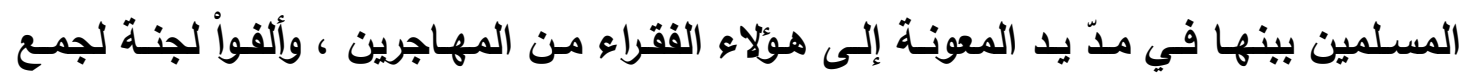

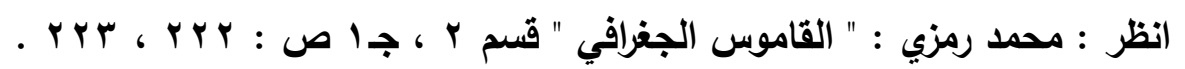

$$
\begin{aligned}
& \text { البلاغ ، عدد 11 يونيو 19 إم . }
\end{aligned}
$$

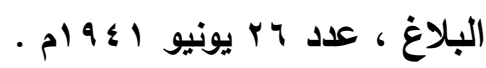

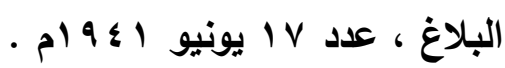

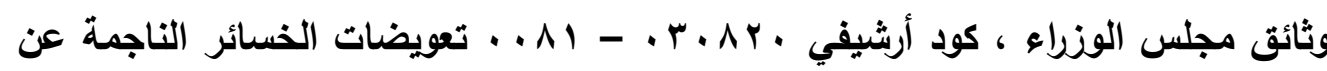

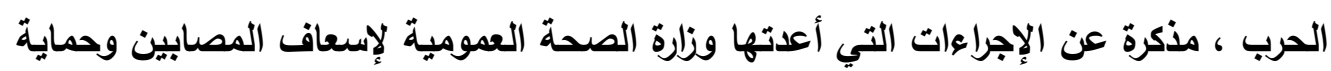

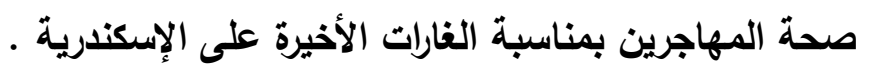


التبرعات ، وقد نجحت اللجنة في جمع مبلغ خمسين جنيهاً أنفقت على هؤلاء المهاجرين (") .

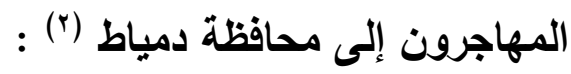

كانت دمياط قبلة المهاجرين من منطقة القتاة ، فقد ازدحمت بهم المدينة ومنازلها

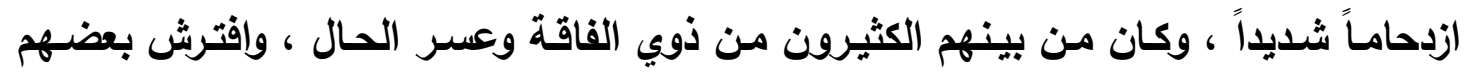

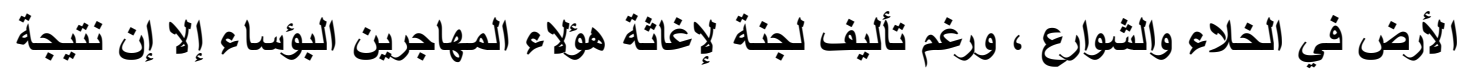

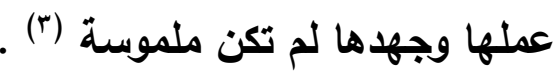

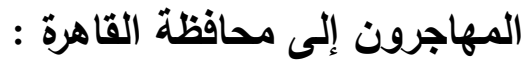
بلغ عدد المهاجرين في القاهرة حوالي خمسة وأريعين ألف مهاجر طبقاً لإحصاء الحكم

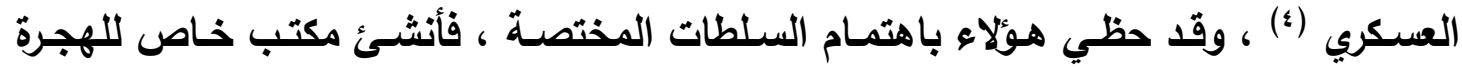

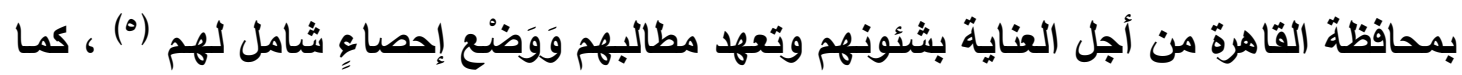
اهتمت السلطات بإسكانهم وإيوائهم في المنازل الخالية في العاصمة ، فقد طلب محافظ القاهرة

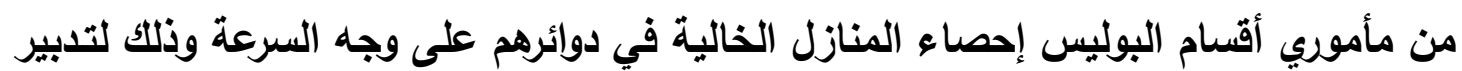

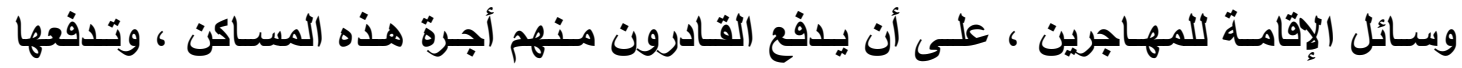

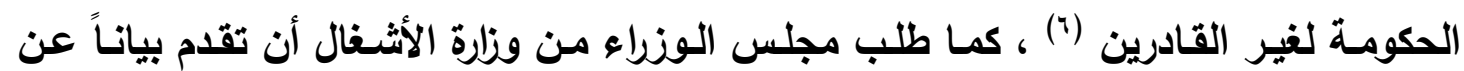

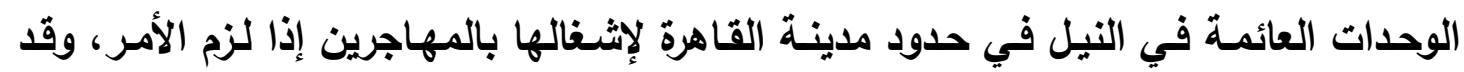

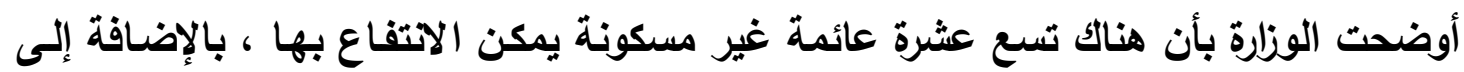

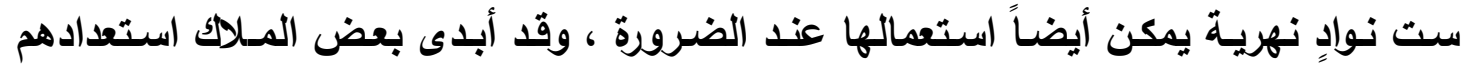

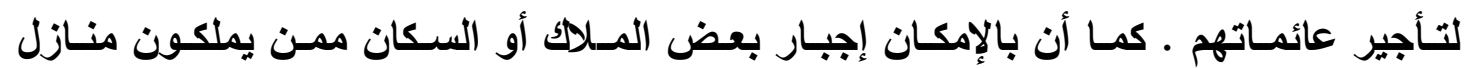

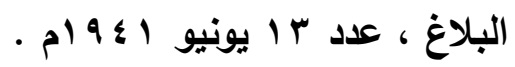

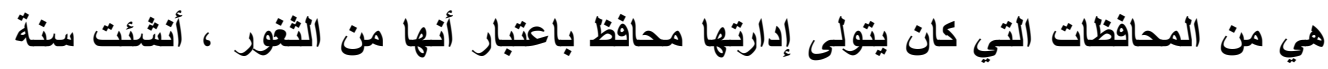

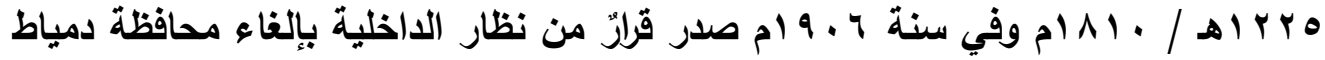

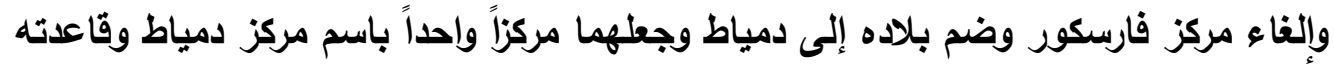

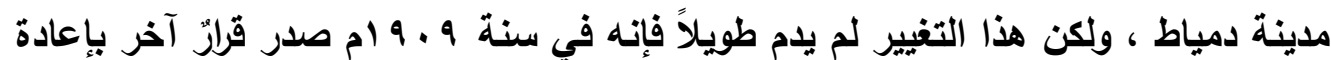

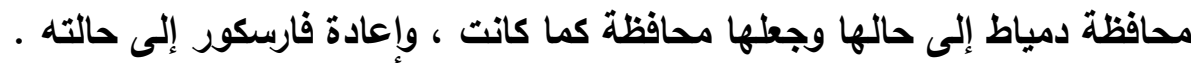

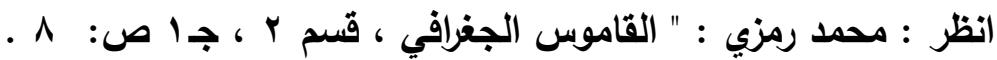

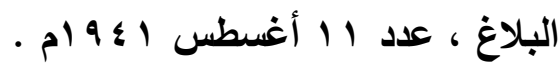

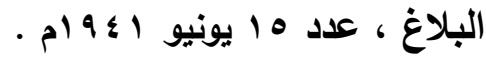

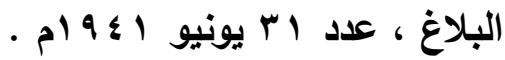

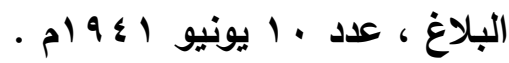


بالقاهرة على الاتتقال إليها ، ومن المفهوم بداهة أن العائمة يمكن أن تسع عدداً من اللاجئين

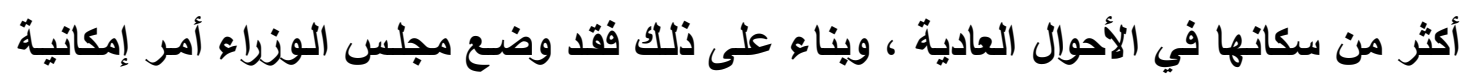

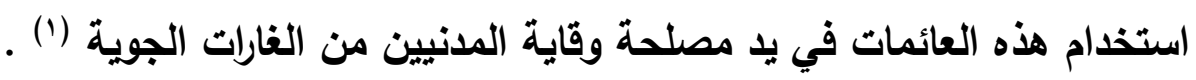

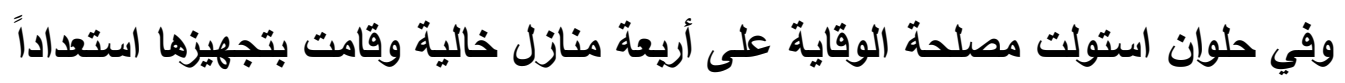

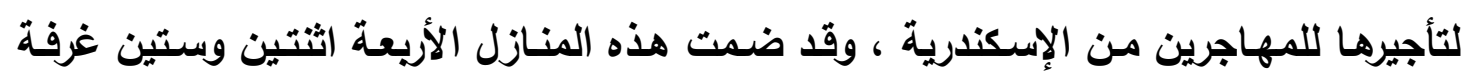

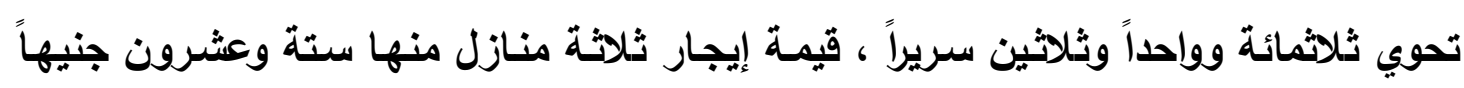

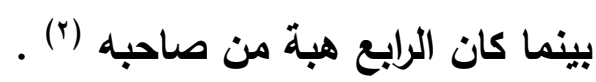
أما غير القادرين على استئجار المساكن من المهاجرين فقد أعدت الحكومـة لسكناهم الجهات التالية : - التاعية 1-مستثفى الهلال الأحمر ، وهو يتبع جمعية الهلال الأحمر ، وقد خصص للمصابين من

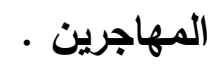
r- دار جمعية الهلال الأحمر بثارع الملكة نازلي ، وقد آوت الجمعية فيها بrس من النسـاء

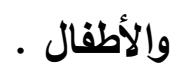

r- ملجأ درب الحجر ، وهو يتبع وزارة الثئون الاجتماعية ، وقد أسكن به ستون مهاجراً .

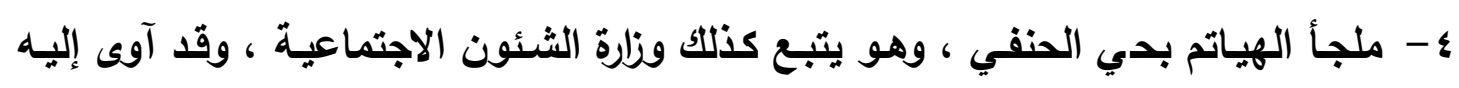

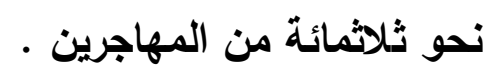

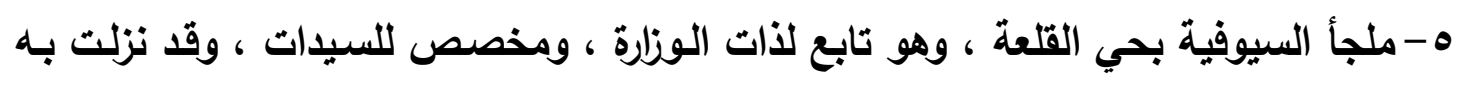

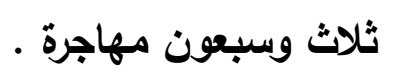

צ- ملجأ أم المحسنين بمصر القديمة وهو يتبع المحافظة ، وعدد نزلانه من المهاجرين مائة

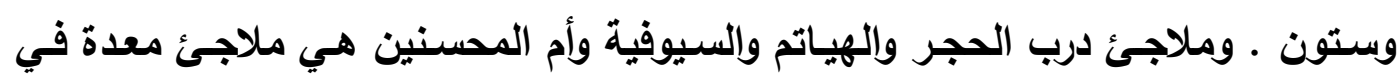

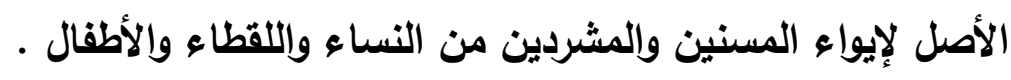
- ملجأ الاححاد النسائي وقد سكنه ثلاثة وثمانون مهاجراً .

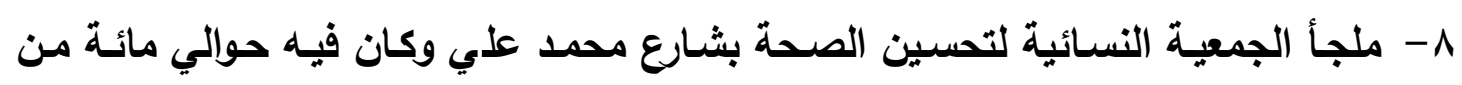

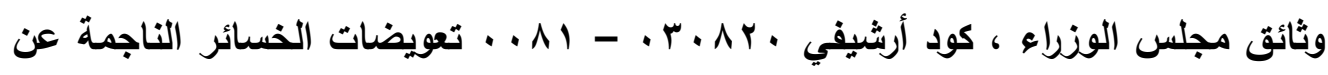

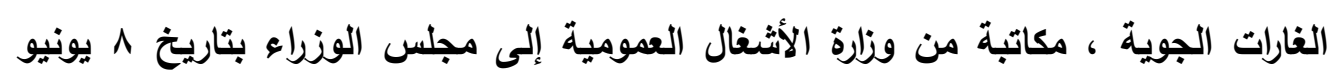

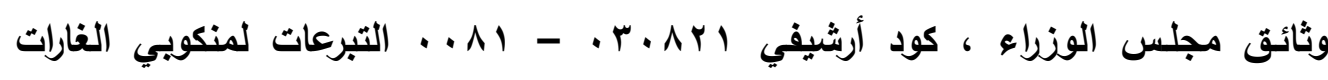

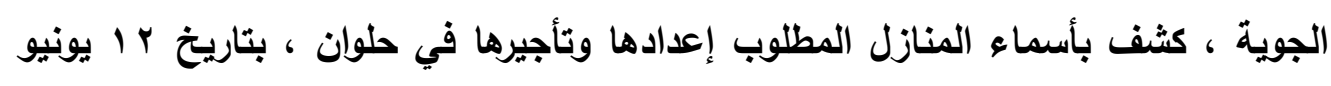


السيدات المهاجرات .

9- - عدة منازل بحلوان ، وقد أسكن فيها حوالي ستمائة من السيدات والرجال (1).

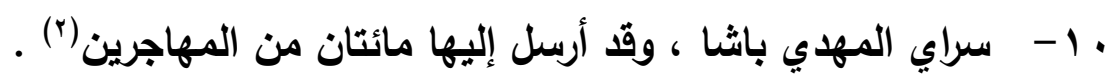

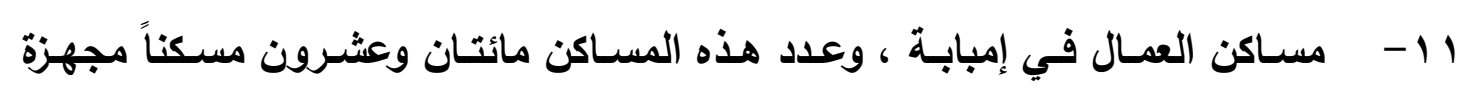

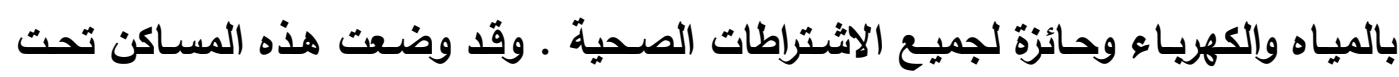

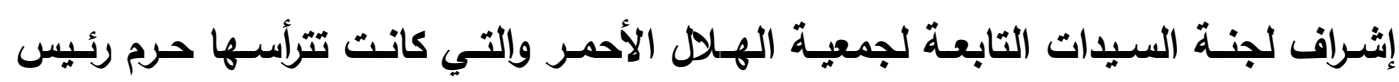

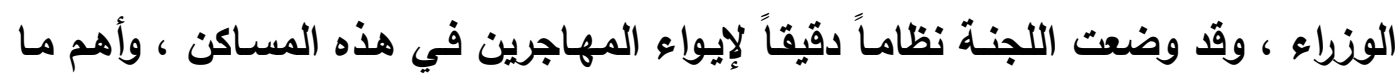

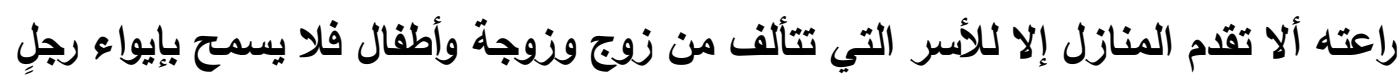

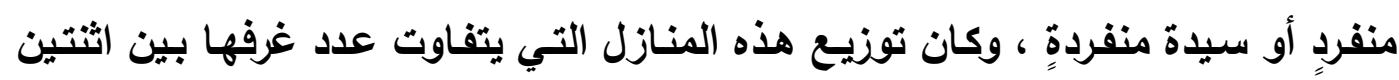

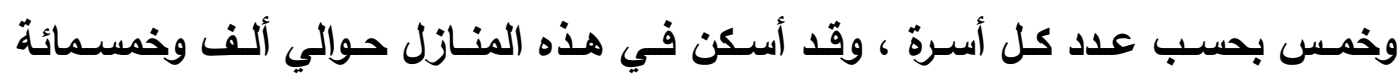

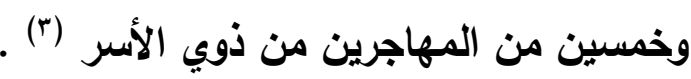

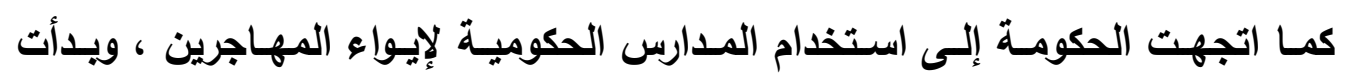

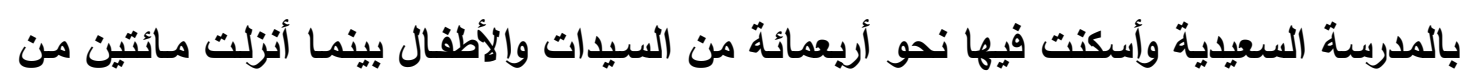

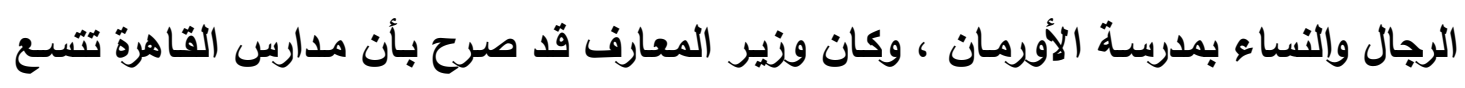

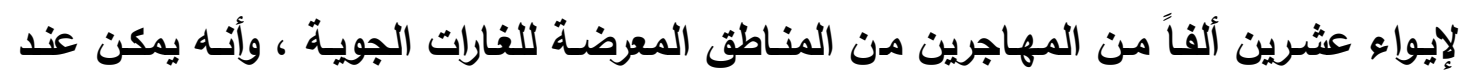

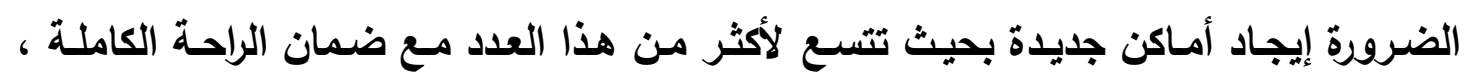

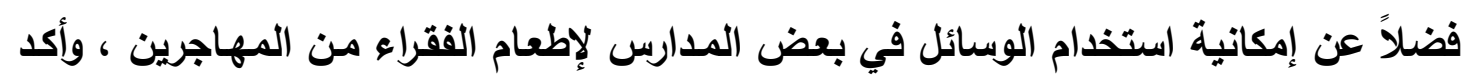

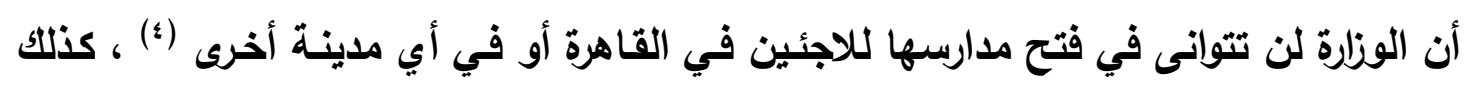

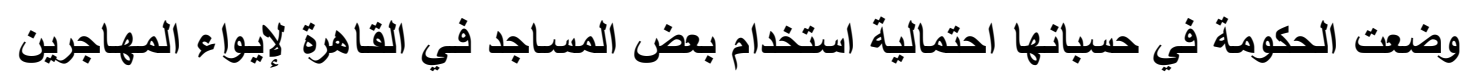

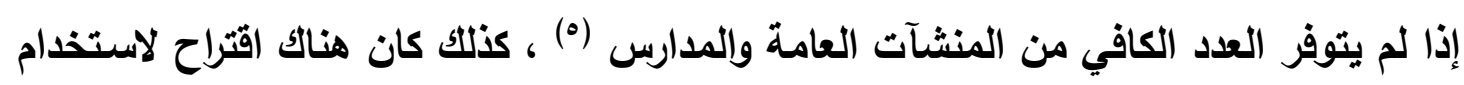

انظر بخصوص هذه الأماكن وأعداد اللاجئين فيها : وثائق مجلس الوزلاء ، كود أرشيفي

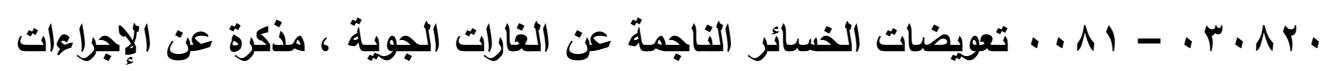

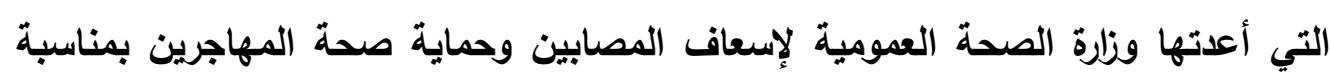

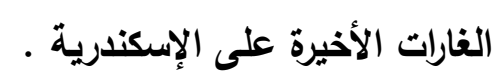

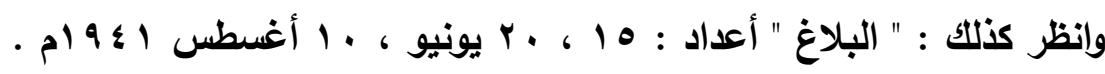

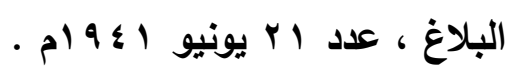

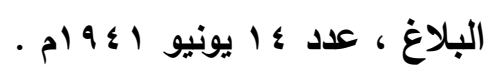

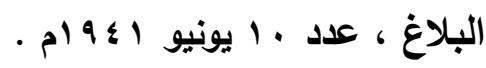

$$
\begin{aligned}
& \text { البلاغ ، نفس العدد . البلاغ ، البد }
\end{aligned}
$$


المدافن الإسلامية كملاجئ للمهاجرين ، ورأت وزارة الوقاية المدنية في هذا الطرح ما يدعو إلى أخذه بعين الاهتمام وأسندت أمر دراسته والبت فيه إلى المسئولين في محافظة القاهرة (1). وطلباً لتيسير عمل الجمعيات الخيرية التي تقام خدماتها للمهاجرين تم تقسيم القاهرة

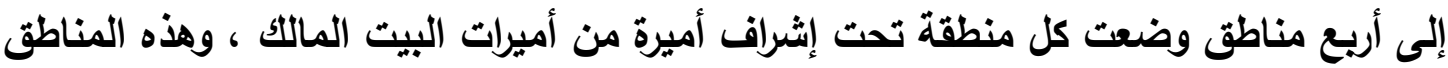
كما يلي :

أ- منطقة الزيتون برعاية الأميرة نعمت مختار (ץ) )

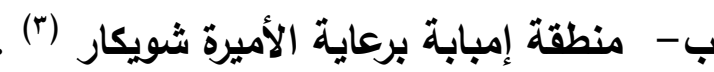

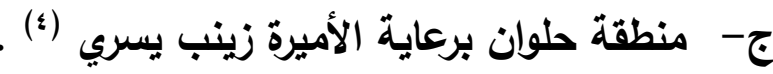

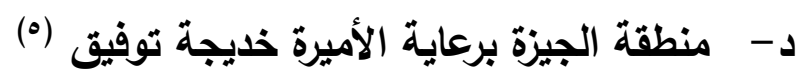

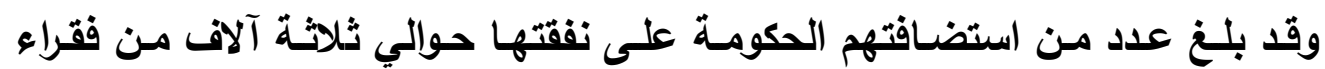

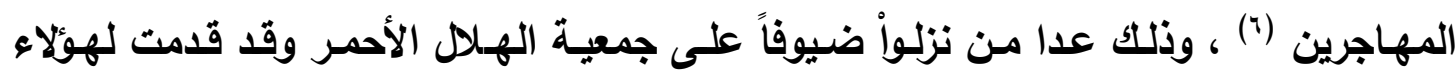

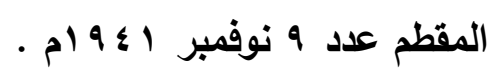

نعمت مختار : كل ما علمناه عنها أنها كانت أخت الملك فؤاد وعمة الملك فاروق ، وأنها كانت

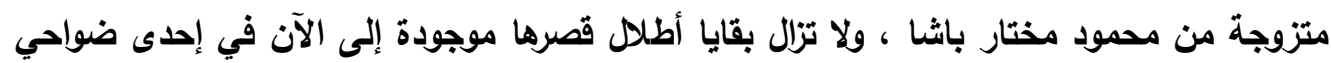

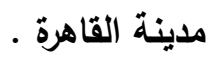
الأميرة شويكار : (

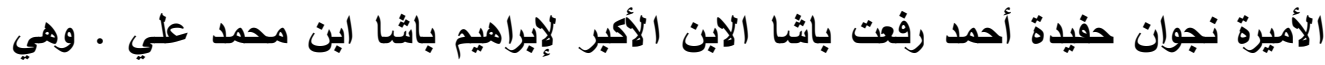

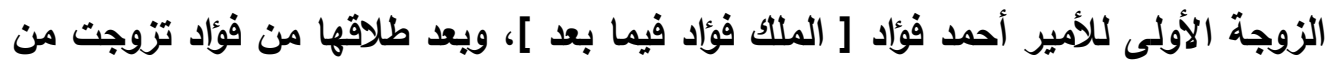

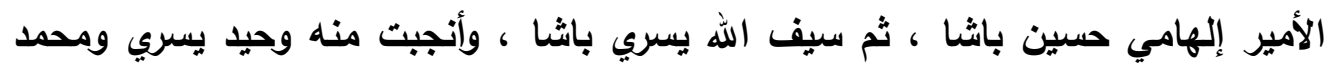

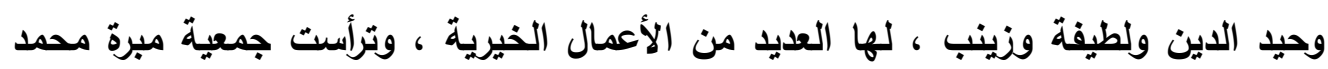

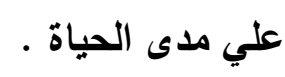

انظر ترجمة لها في الثبكة الدولية للمطلومات ، موقع : www. wikipedia.org زينب يسري : فُهم من ترجمة الأميرة شويكار السابقة أنها ابنتها من زوجها الثالث سيف الله يسري

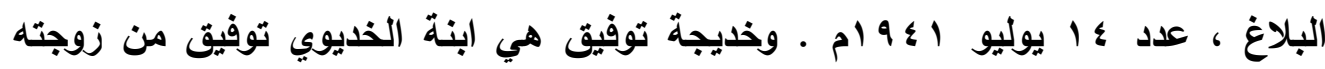

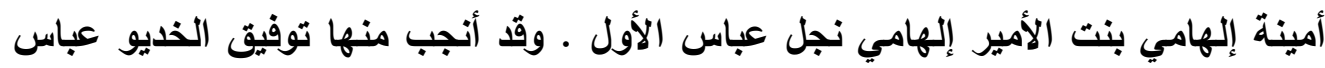

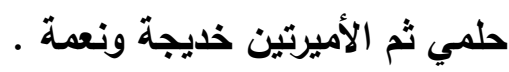

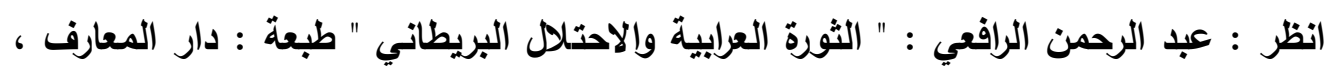

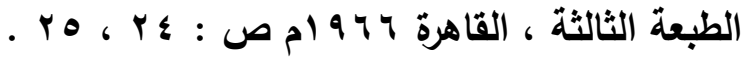

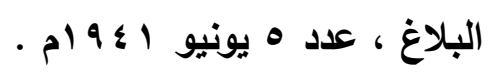


وأولئك كل التسهيلات الممكنة ، بدءاً من توفير سيارات لنقلهم منذ وصولهم إلى محطة القاهرة

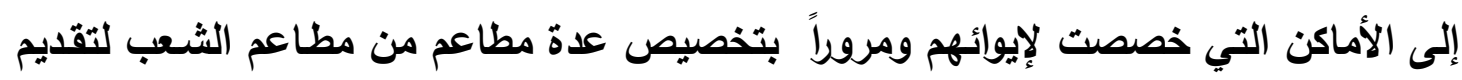

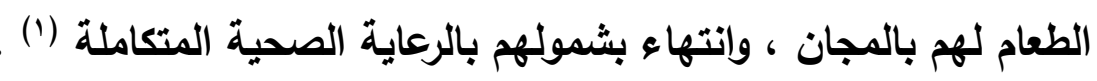

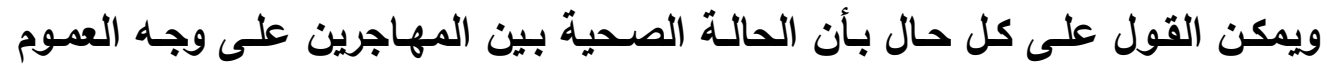

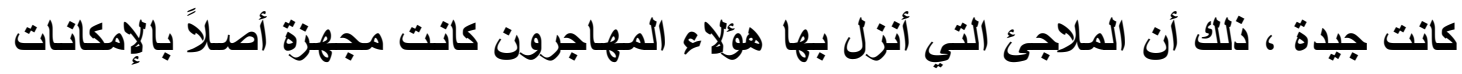

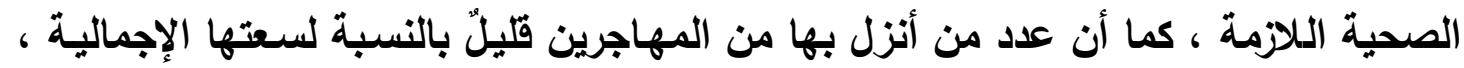

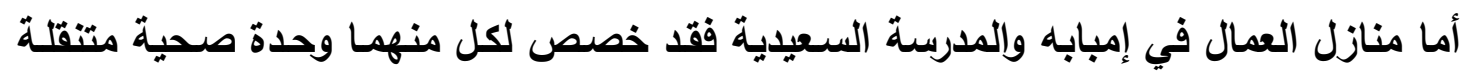

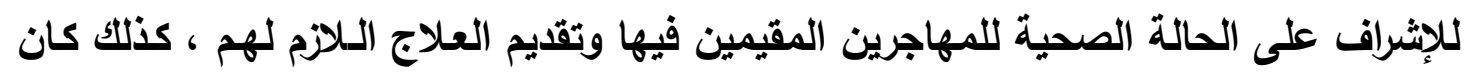
تفتيش صحة القاهرة على اتصال مستمر بجمعية الهلال الأحمر ويقوم بالإثراف يومياً على لهئ

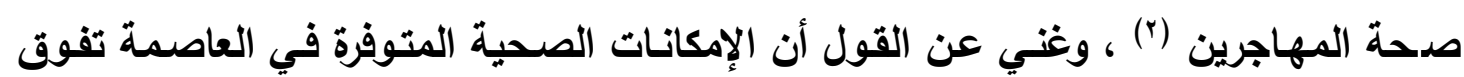
مثيلاتها الموجودة في الأقاليم الأخرى .

وقد اتخذت عدة إجراءات من شأنها حماية المهاجرين من الاستغلال ، فتقرر مراقبة

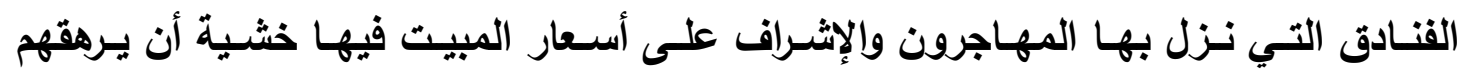

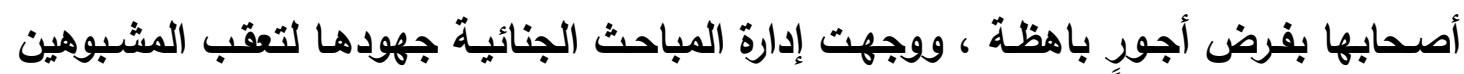
والنثالين واعتقالهم خشية أن يندوا بين جموع المهاجرين عند نزولهم بمحطة القاهرة ، كما

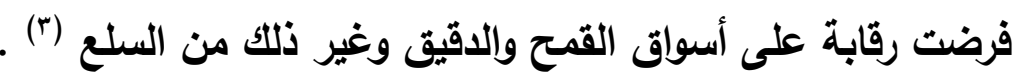
المهاجرون إلى مديرية الجيزة :

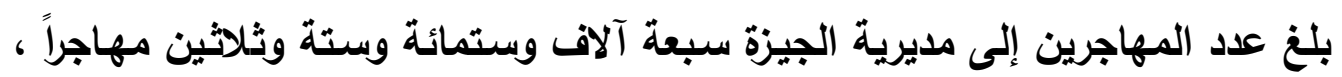
وقد اتخذ المسئولون في المديرية الوسائل التي تكفل توفير أسباب الراحة لهم وإيجاد الأمساكن

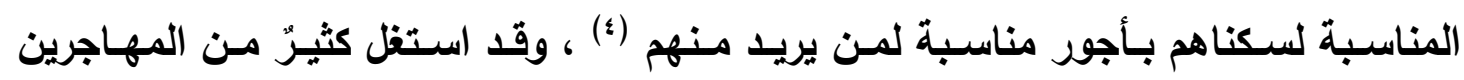

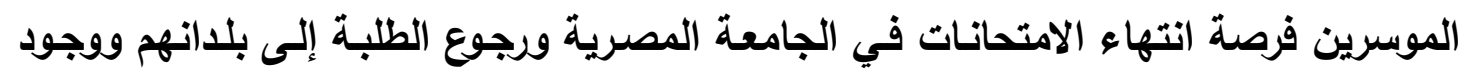

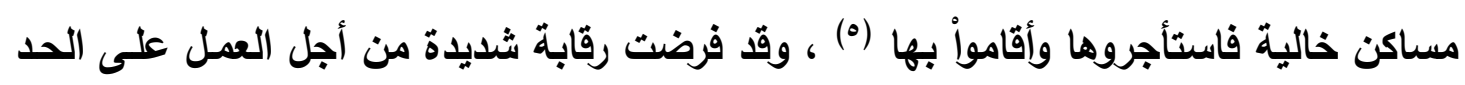

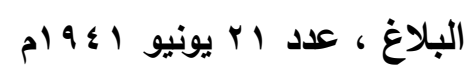

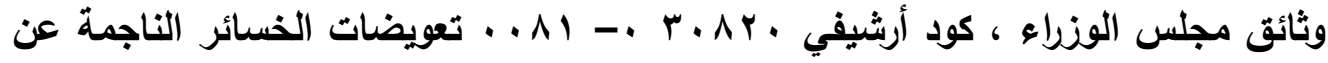
الغارات الجوية ، مذكرة عن الإجراءات التي أعدتها وزارة الصحة العمومية لإسعاف المصابئ العابين

، وحماية صحة المهاجرين بمناسبة الغارات الأخيرة على الإسكندرية .

$$
\begin{aligned}
& \text { البلاغ ، عدد 1ل يونيو إ؛ } 9 \text { ام . }
\end{aligned}
$$

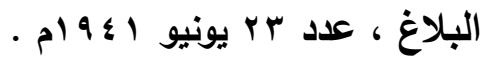

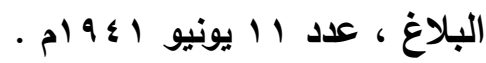


من جثع بعض الملاك حتى لا ينتهزواً هذه الفرصة لرفع أجور مساكنهم (') ، كما صدرت

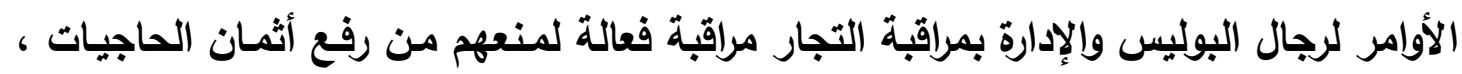

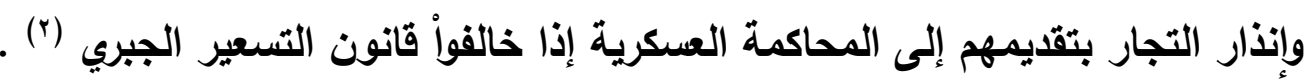

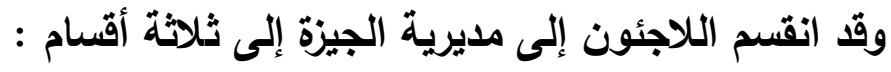

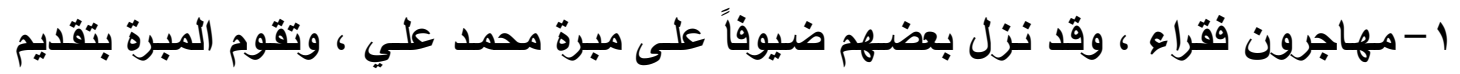

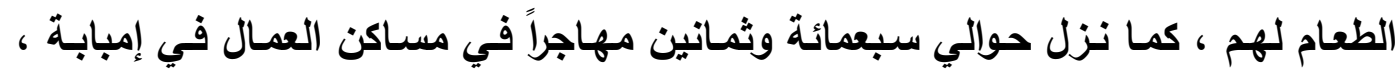

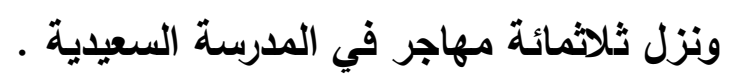
r - مهاجرون نزلواً ضيوفاً عند ذويهم وأقربائهم وأصدقائهم وهؤلاء لا يحتاجون إلى معونـة

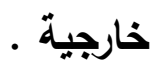

r- مهاجرون استأجرواً مسـاكن لعسابهم وهم ميسورو الحسال ، وقد سـاعد انتهاء السنة

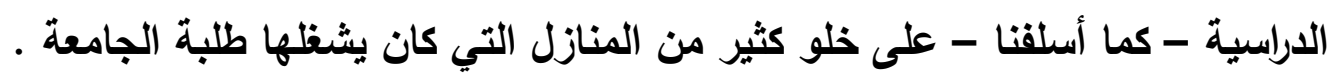

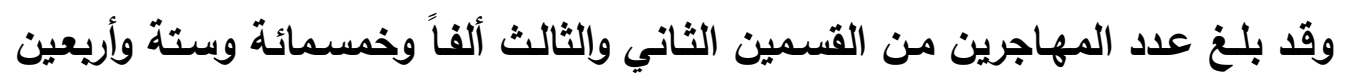

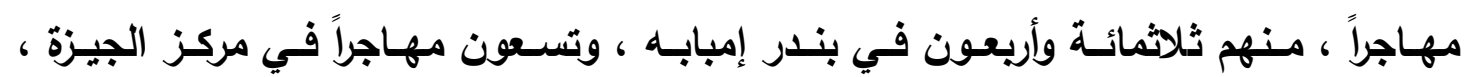

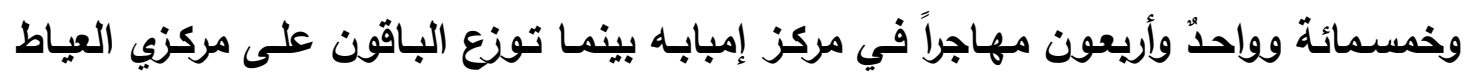

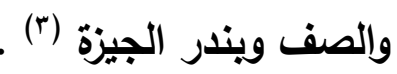
وقد طلب مدير الجيزة أن يرفع إليه تقريرٌ يومي عن حالة المهاجرين ، وأصدر أوامره

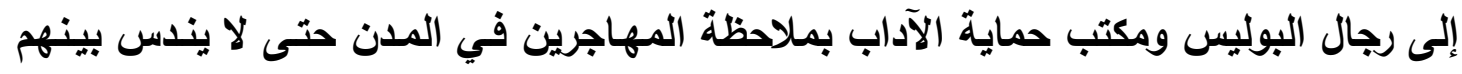
بعض الأثرار فيعبثون بالأمن أو يضرون بالآداب العامة (؛) .

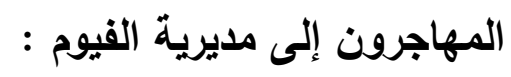
لا يُعلَم على وجها التحديد عدد المهاجرين الذين لجأواً إلى مديريـة الفيوم ، ولكنتا

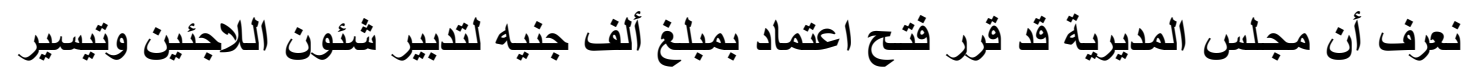

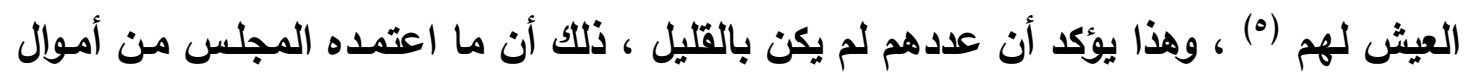

$$
\begin{aligned}
& \text { البلاغ ، عدد بr يونيو 19 الم ام . }
\end{aligned}
$$

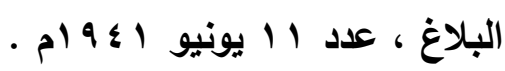

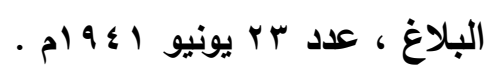

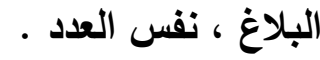

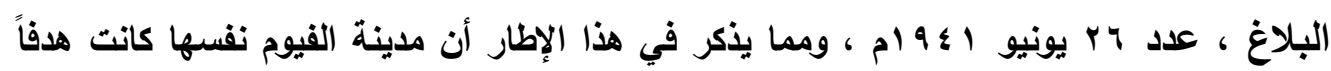

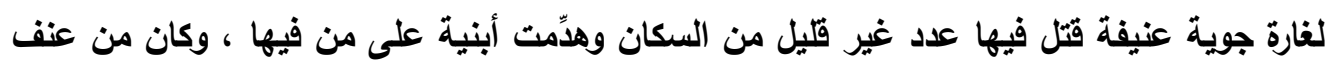


للإنفـاق على هؤلاء المهاجرين لـم يكن يقل عمـا اعتمدته المجالس الأخرى المشـابهة في

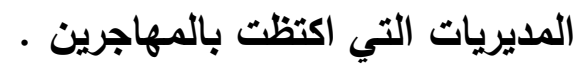
المهاجرون إلى مديرية بني سويف :

وفد على بني سويف حوالي خمسمائة من المهاجرين السكندريين ، وقد نزلواً جميعاً

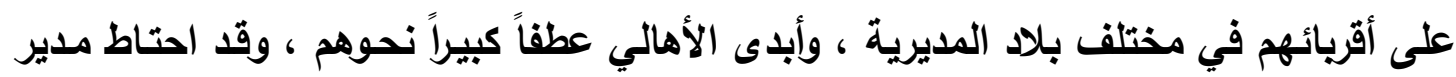

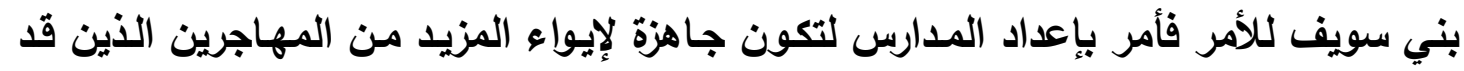

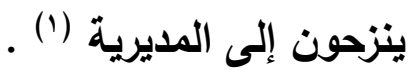

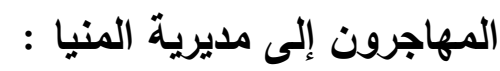

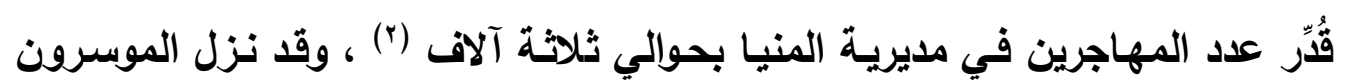

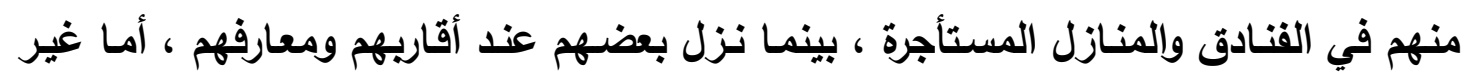

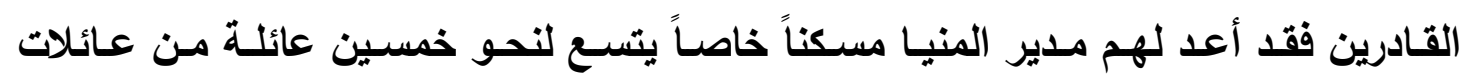

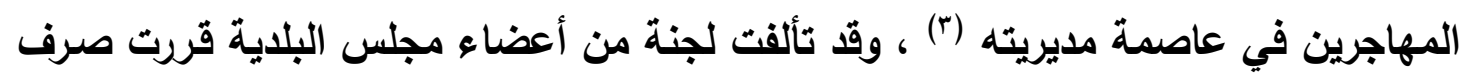

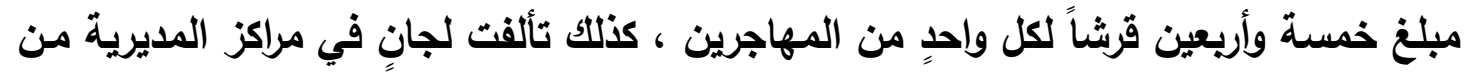

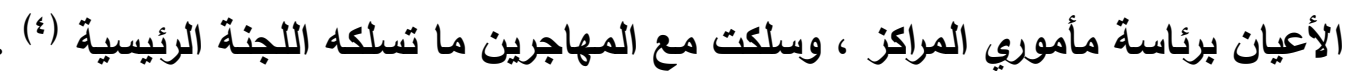

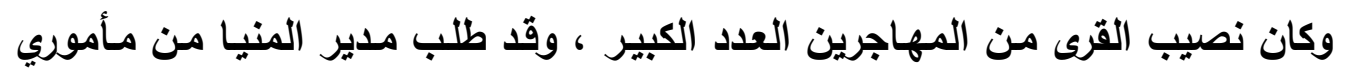

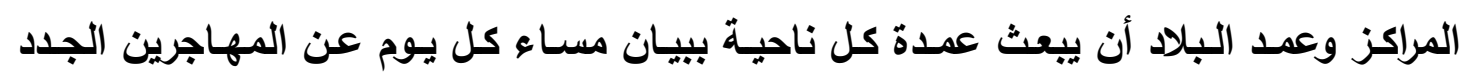
وعددهم ومدى قدرة كل منهم ، ومدى قدرة الوافدين عليهم على تقديم المعونـة اللازمـة للفقراء

وقد وقف أهالي مديرية المنيا موقفاً محموداً من المهاجرين فتبرع كثيرٌ منهم بغرف

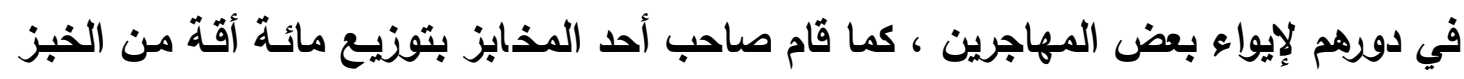

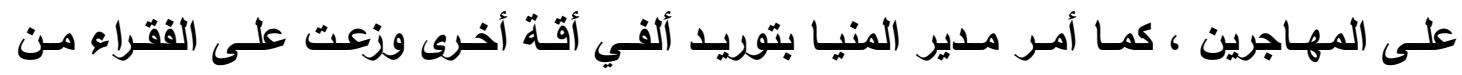

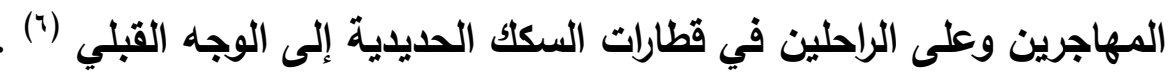

الغارة وشدتها أنها أصبحت موضوعاً لاستجواب قدمه أحد أعضاء مجلس النواب إلى رئيس مجلس

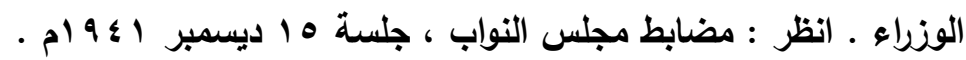

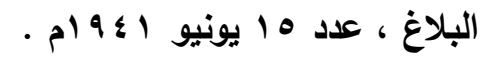

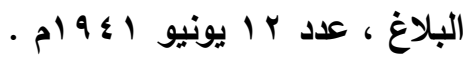

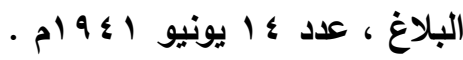

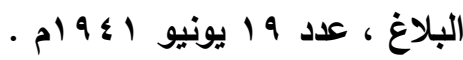

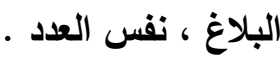

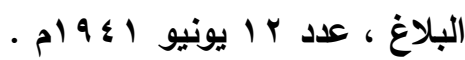




$$
\text { المهاجرون إلى مديرية أسيوط : }
$$

استقبلت أسيوط نحو أربعين ألنف مهاجر ، وفدواً في عثدرين قطاراً مـن قطارات

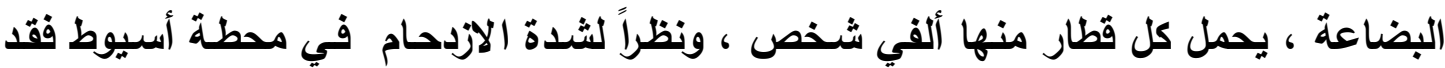

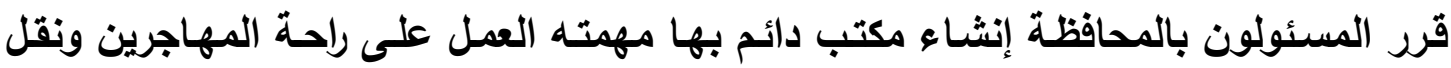

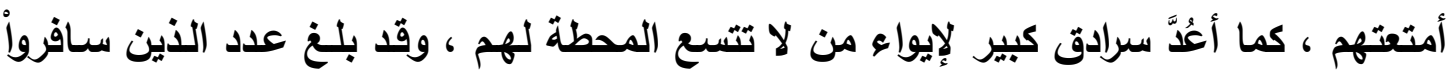

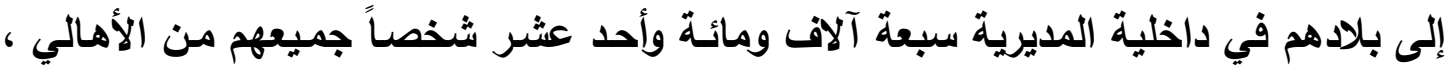

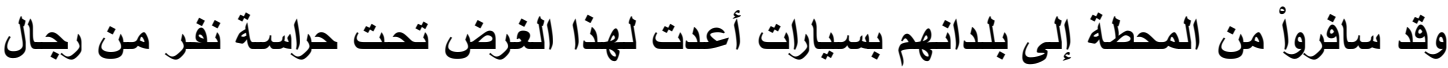

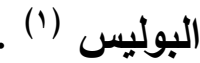

وقد قام رجـال الإدارة بحصر الأمساكن المملوكـة للحكومـة أو للأهـالي أو للهيئات ممـا

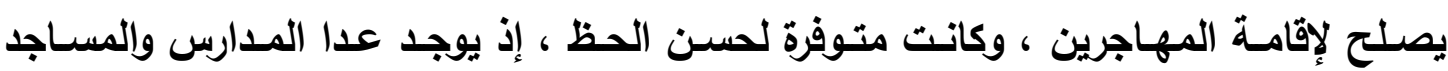

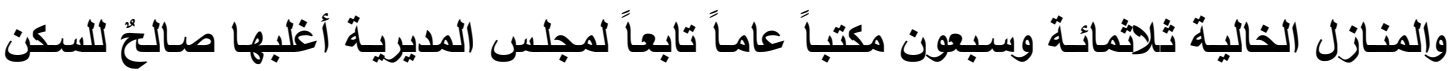

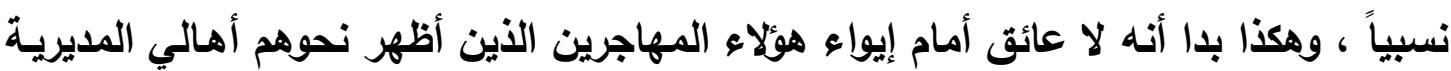

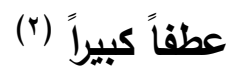

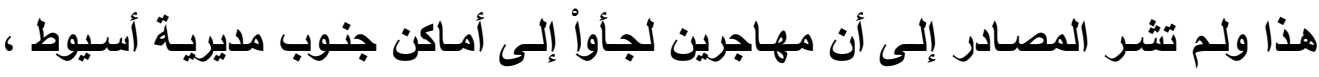

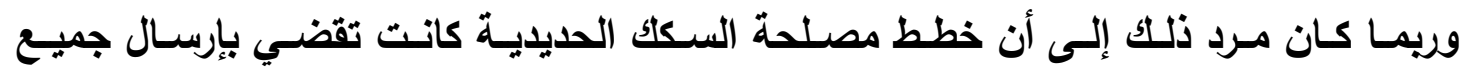

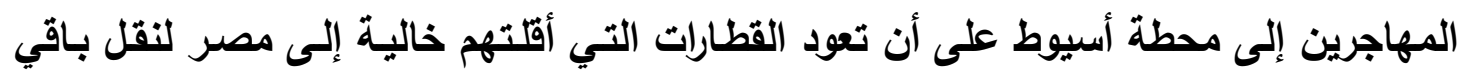

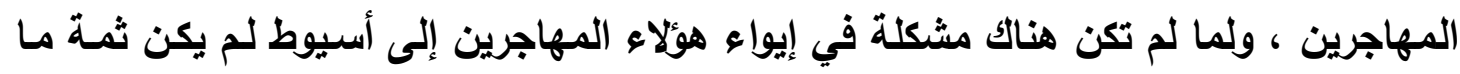

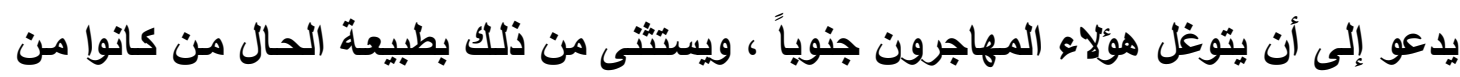

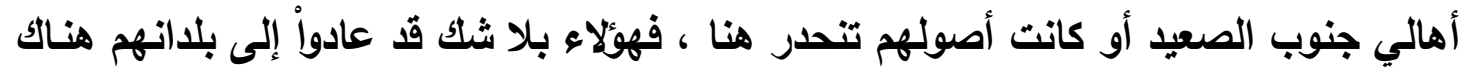

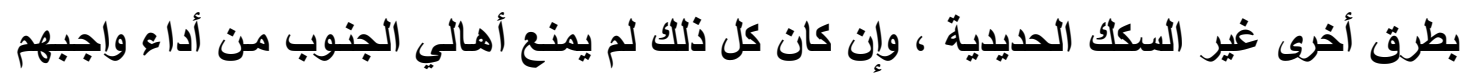

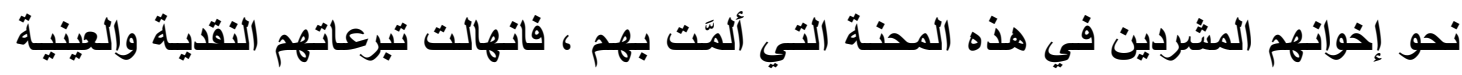

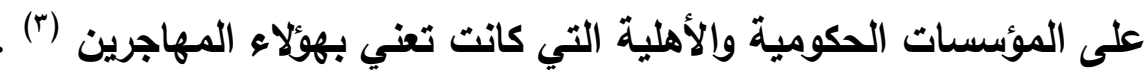

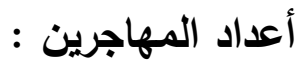

لسنا في حاجة إلى البسط في الحديث عن الأعداد التقريبية لهؤلاء المهاجرين بعد أن

$$
\begin{aligned}
& \text { البلاغ ، عدد بr يونيو إ؟9 ام . } \\
& \text { البلاغ ، نفس العدد . البلاع ، علدد }
\end{aligned}
$$

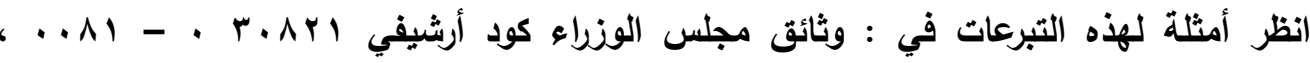

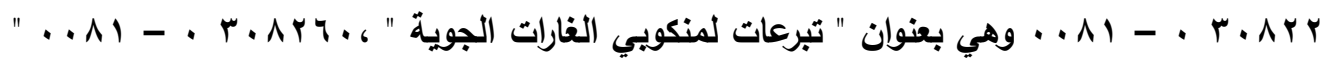
تبرعات لجمعيتي الهلال الأحمر والصليب الأحمر " . 
أوردنـا لـك في كـل مديريـة - تقريبـاً - عدد مـن خرج منهـا أو عدد مـن دخل إليها مـن

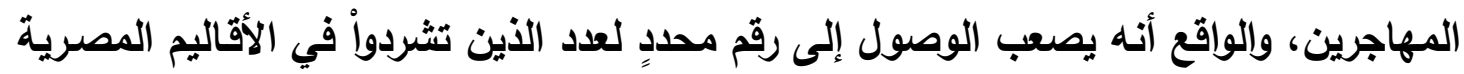

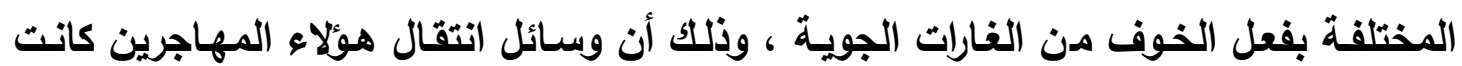

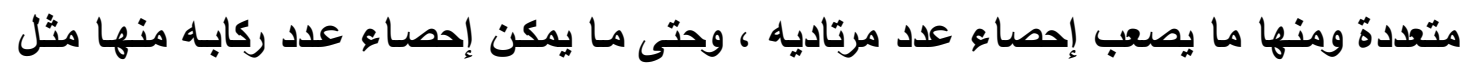

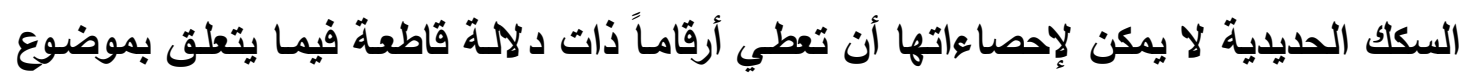

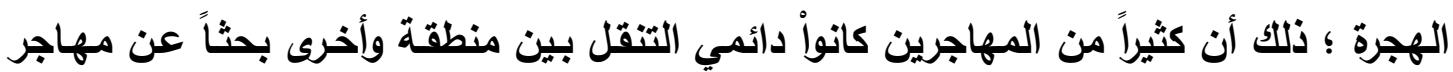

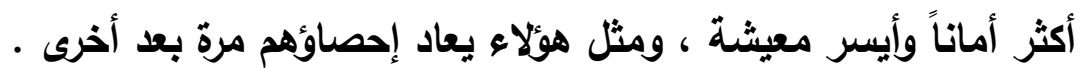

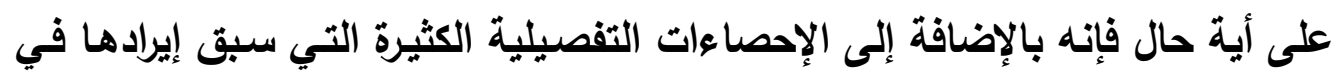

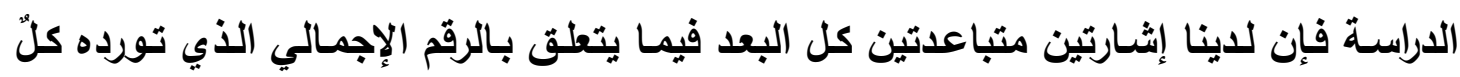
منهما : الأولى : من جانب الحكومة المصرية وهي مباشرة في موضوع بحثنا وتقول إن عدد

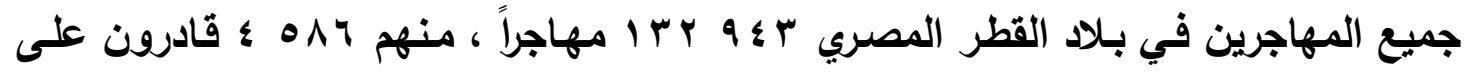

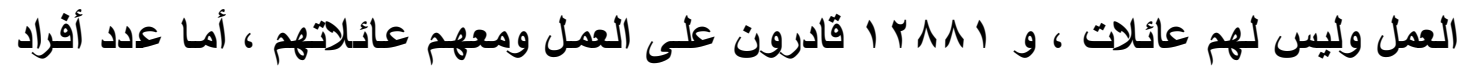

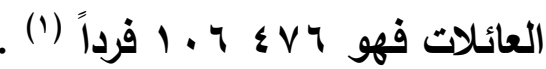
والثثانية : جاعت عرضاً عند حديث السكك العديدية عن نشاطها في مجال النقل خلال

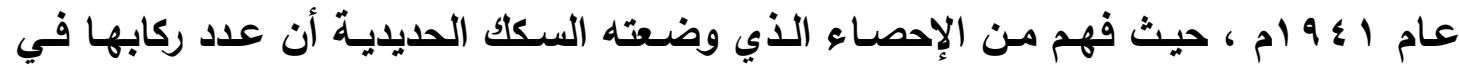

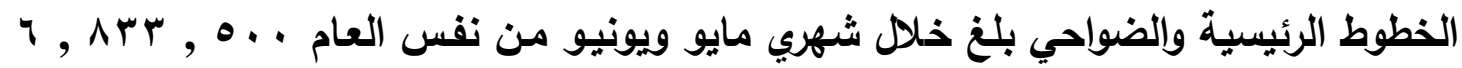

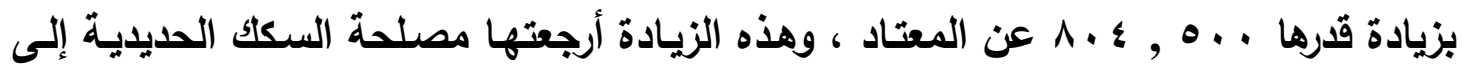

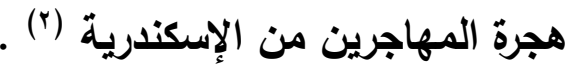
والرقم الأول فيه بخسُ شديد ، وريما كان مقصوراً على من بقي في المهاجر ممن

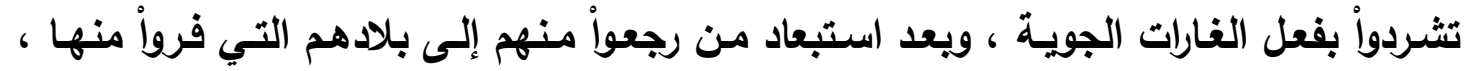

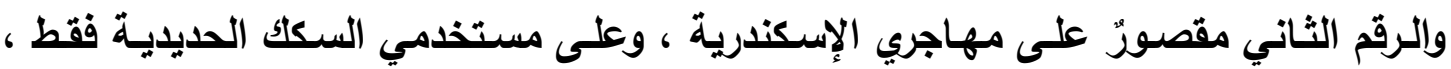

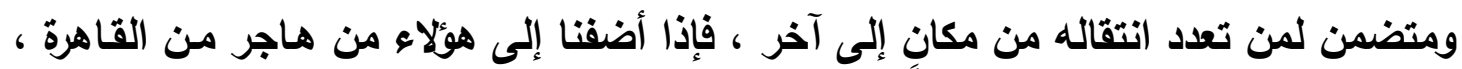

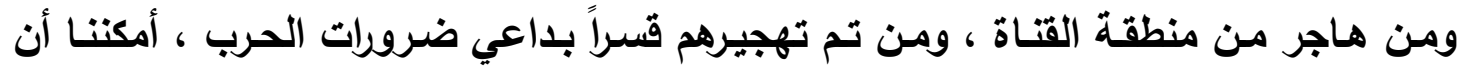

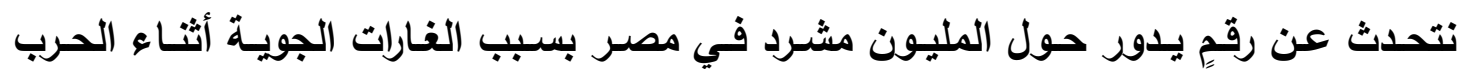

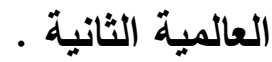
مآسي المهاجرين :

$$
\begin{aligned}
& \text { البلاغ ، عدد ^ץ يونيو 1؟9 ام . }
\end{aligned}
$$

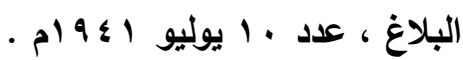


في مثل هذه الظروف القاسية التي عاشها الشعب المصري لابد أن تطفو على السطح

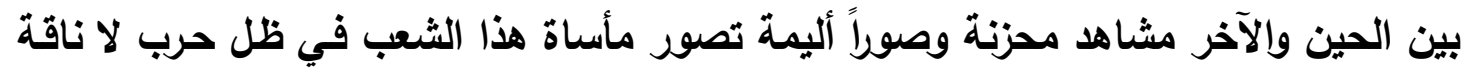

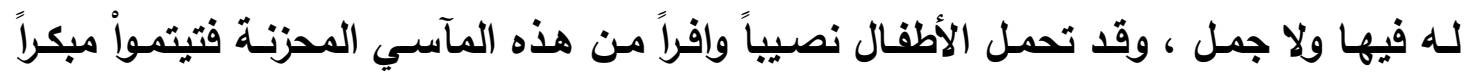

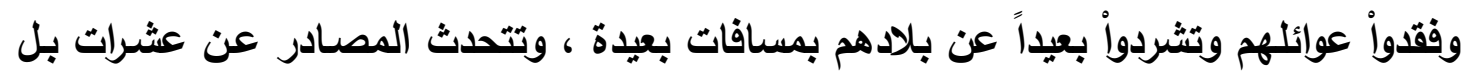

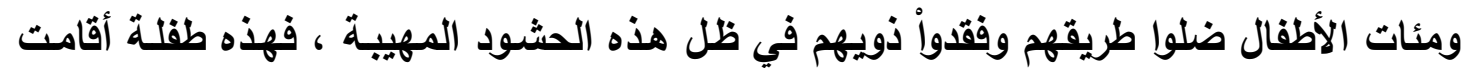

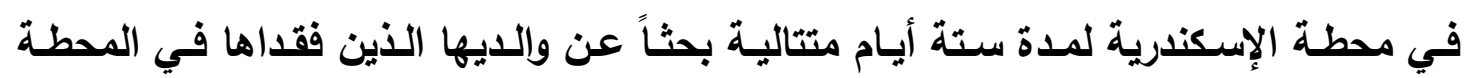

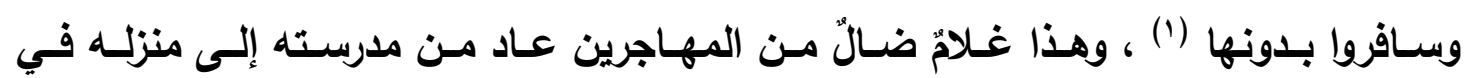

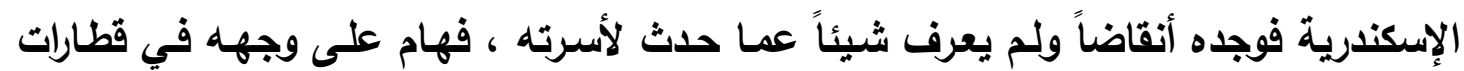

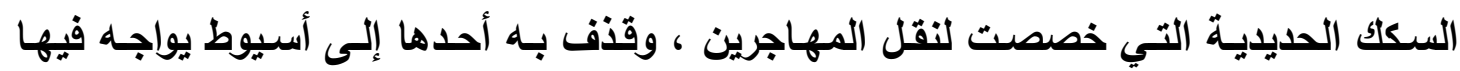

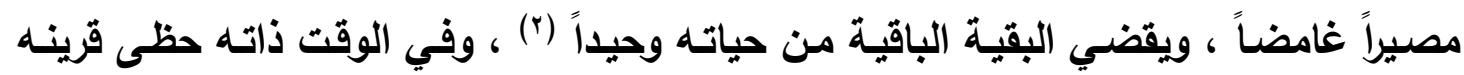

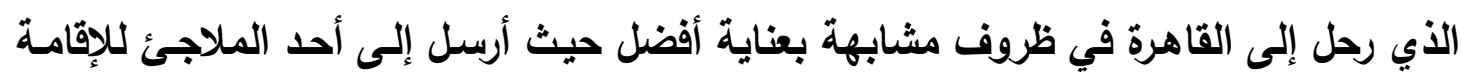
فيها (r) ومن المآسي أن سيدة من المهاجرين الذين وصلواً بقطارات البضـاعة إلى مديريـة

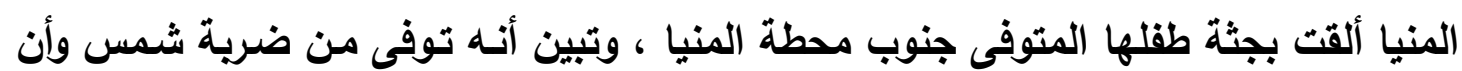

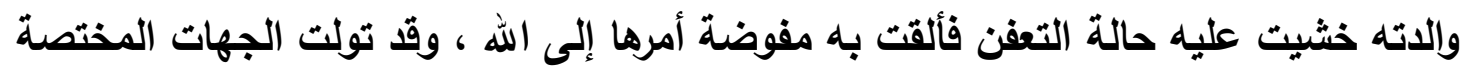

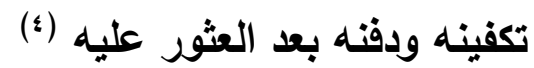
ولم تفرق هذه الأوضاع المأساوية بين غني وفقير ولا بين شريف ووضيع ، فأحد

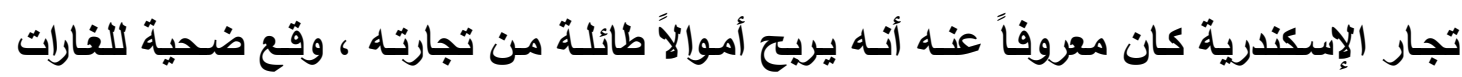

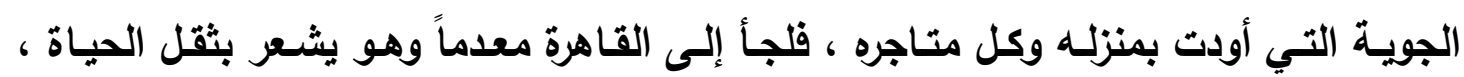

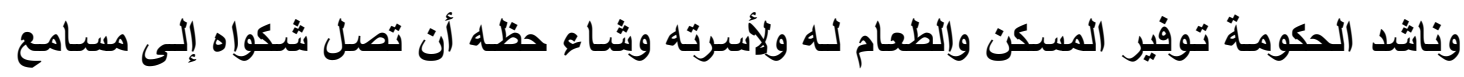

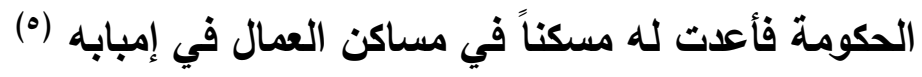

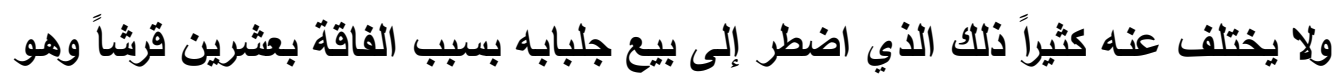

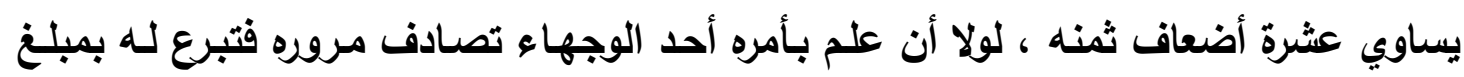

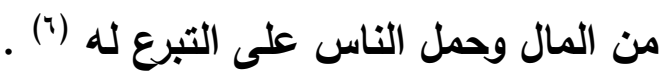

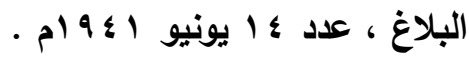

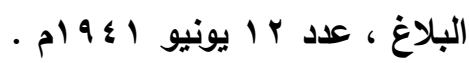

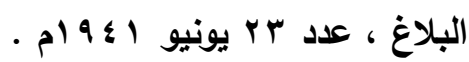

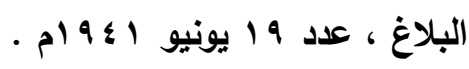

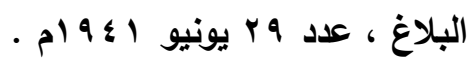

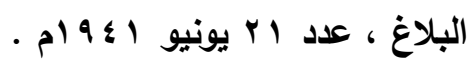


وكأن ما حلَّ بهوّلاء من الفقر والعوز والتثرد لم يكن كافياً من وجهة نظر البعض

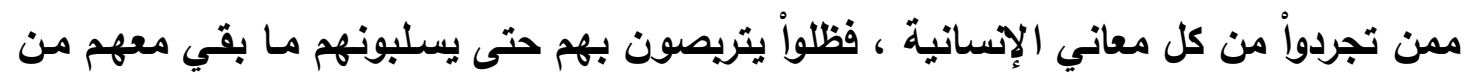

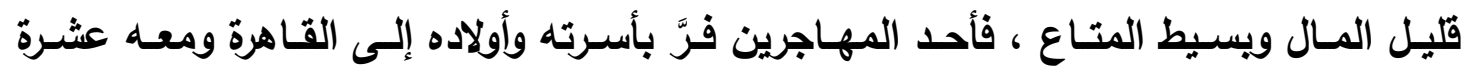

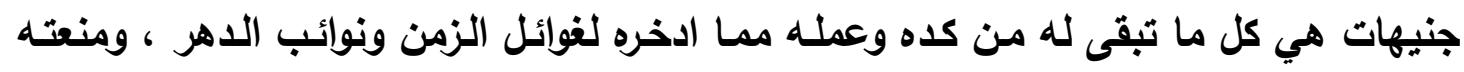
نفسه الأبية من أن يعيش على صدقات الناس أو أن ينتظر إحسان الحكومـة ، فاستأجر داراً

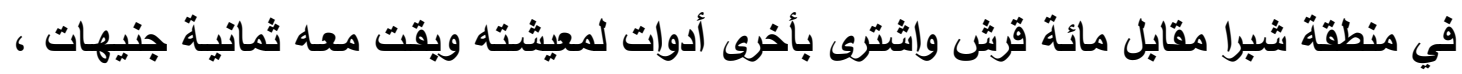

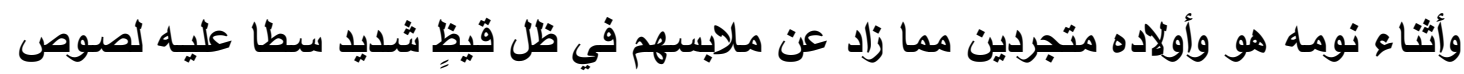

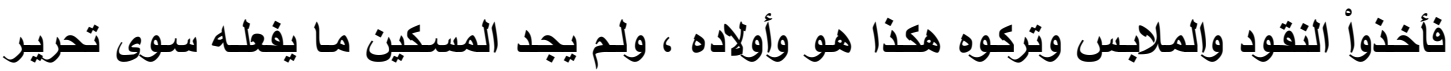

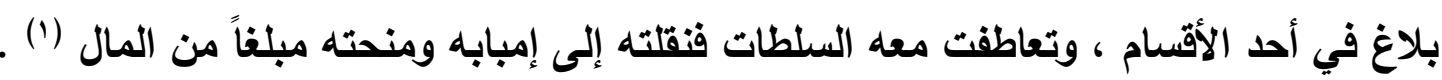

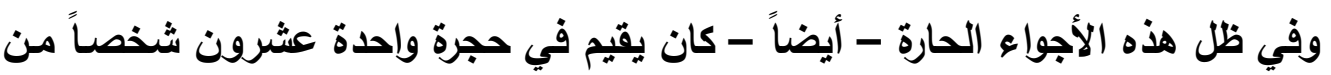

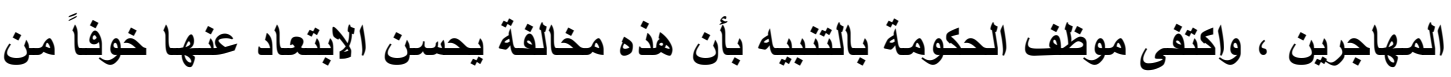

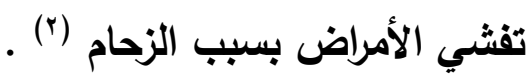
مثل هذه المشـاهد المحزنة وغيرها تنبئك بحجم المأسـاة التي حلت بالثعب المصري

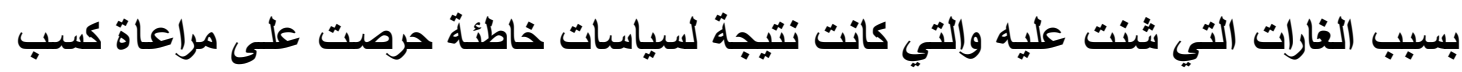

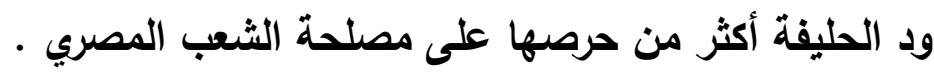

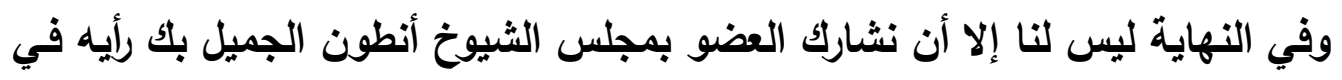
أن أفضل وصفٍ ينطبق على هؤلاء المهاجرين المنكويين هو ما نظمهـ أمير الثـعراء أحمد شوقي حين قال :

ضَتَّوا السَبِيلَ مِنَ اللُهولِ وَهاموا

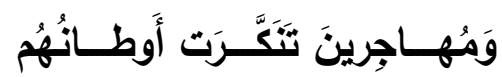

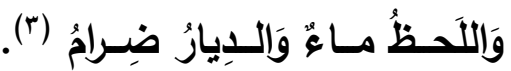

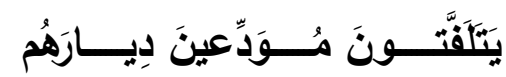

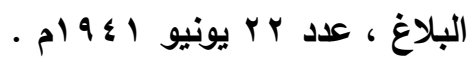

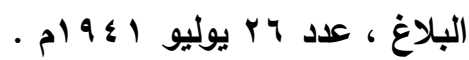

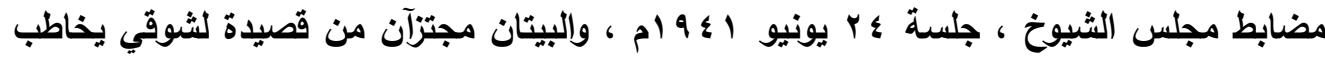

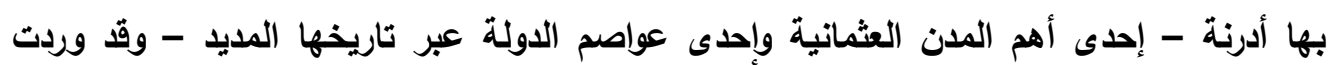

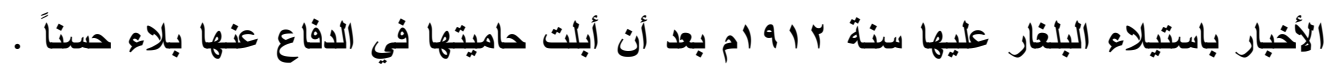
والمغنى : ذهبواً على وجوههم لا يدرون أين يتوجهون ودموعهم منهمرة والدايار مشتطلة ناراً .

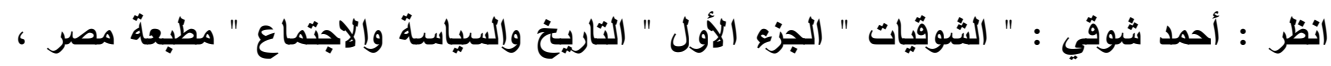

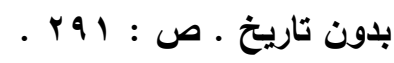




\section{الغاتمة}

ويعد أن انتهينا من عرض قضايا هذا البحث بجزئياتها وتفصيلاتها يجدر بنا أن نثبت هنا ما خلص إليه هذا البحث من حقائق تاريخية والتي من أهمها :

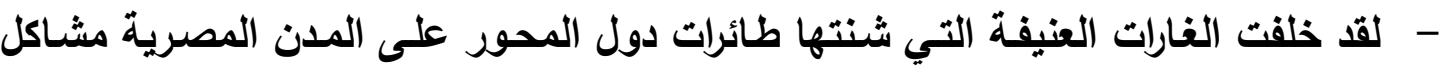
صحية واجتماعيـة عديدة ، كانت أولاهـا مشكلة الهجرة التـي تثـعبت إلى مدن القطر

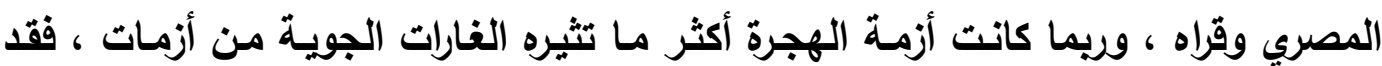

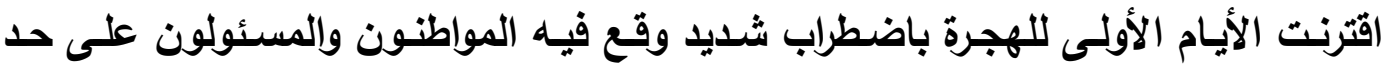
سواء .

- كان ينبغي الاستعداد للهجرة متى لاحت في الأفق نذر الحرب ، وقد استُعِدَّ لها فعلاً ، ووُضِعت الخطط اللازمسة لمواجهتها إذا وقعت ، ولكن التجربـة أثبتت أن التخطيط شيء

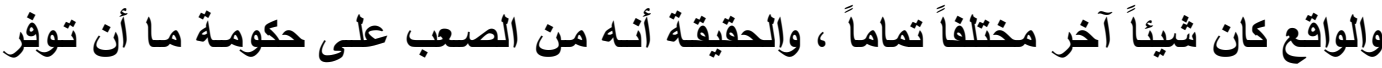
مآوى وملاجئ وطعاماً واحتياطات صحية لمئات الآلاف من المشردين في مناطق متفرقة

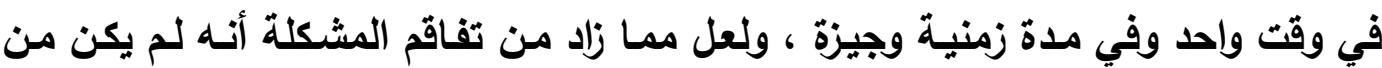
الميسور السيطرة على تلك الجموع الهائجة التي تتطلع إلى النجاة بحياتها ، ولم يكن من

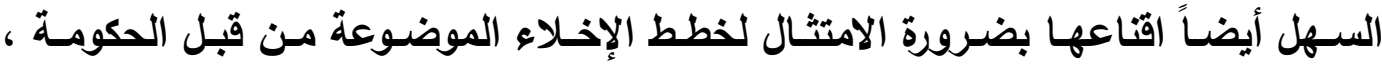
فالواقع يؤكد أن كل فريق من المهاجرين قد اختار الوجهة التي يراها مناسبة لـه فترتب على ذلك اختلل واضح في عملية توزيع المهاجرين على البلدان المختلفة بثكل أدى إلى إنى اكتظاظ بعض المدن بأعداد من المهاجرين لم يكن بإمكان بنيتها التحتية أن تتحملها ، في حين أن مناطق أخرى نائية مثل جنوب الصعيد كانت بعيدة تماماً عن حسابات الحكومـة والمهاجرين

- كانت واضـحة تمامـاً مسـألة عدم تنظيم الهجرة كمـا تفعل اللدول الأخرى بحيث تصبح

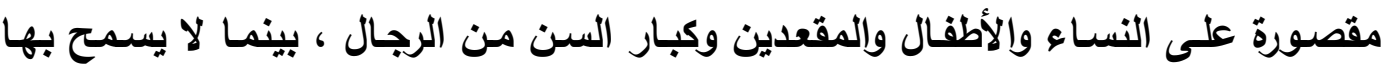
للقادرين على العمل والاتتاج حتى لا تتوقف عجلة الحياة في البلدان التي تخرج منها الهجرات ، مـع إلزام الحكومـة في الوقت نفسـه بتوفير سبل الوقايـة لهؤلاء من أخطار الغارات الجوية عن طريق بناء المخابئ المخصصة اللازمة داخل المدن نفسها ، أو إقامـة معكرات خارجها وقريبة منها لهؤلاء العمال بحيث يبيتون فيها ليلاً ثم يعودون لمزاولئة أعمالهم في المدينة نهاراً . - تتحمل الحكومة مسئولية عدم التزامها باتباع مبدأ الحياد بين المعكرين المتصارعين كما

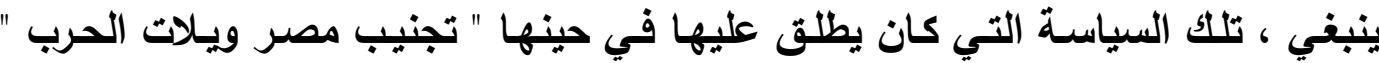


ورغم أن ذلك كان هو الموقف الرسمي والمعلن للحكومـة المصرية إلا أن تصرفاتها في

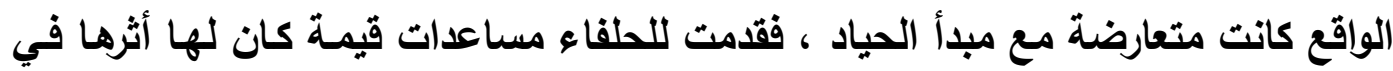
تحقيق النصر ، وكاتت الحكومة تفخر بذلك وتصرح به علانية بعد انتهاء الحرب ، ولعل

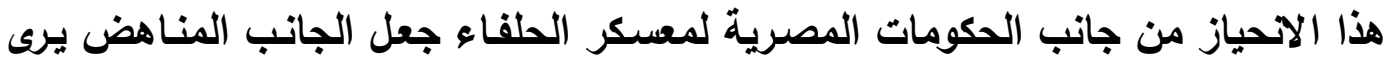
فيها دولة معادية أكثر منها محايدة ، فجعل منها هدفاً لغاراته ، واستخدم في هذه الغارات

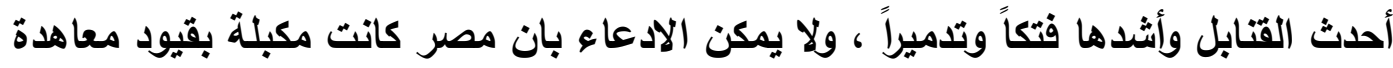

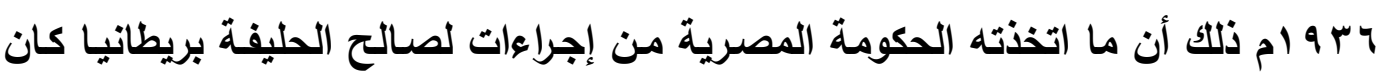
يفوق التزاماتها بمقتضى هذه المعاهدة بمراحل كثيرة .

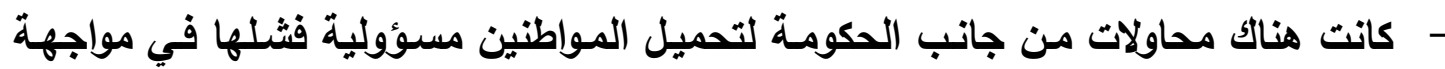

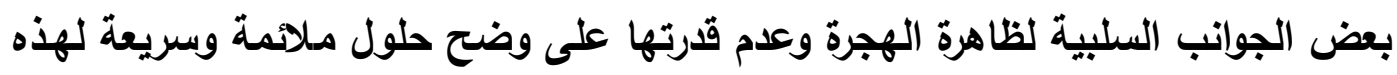

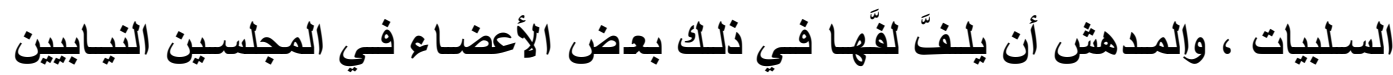

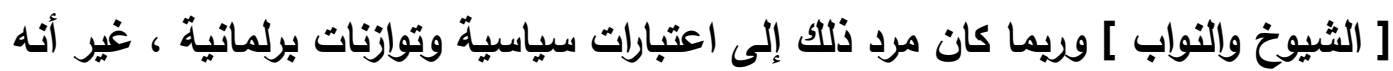

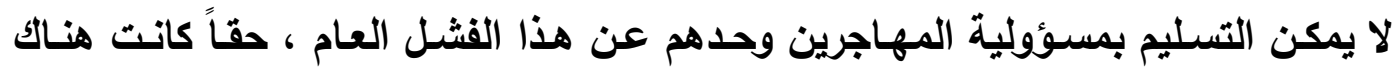

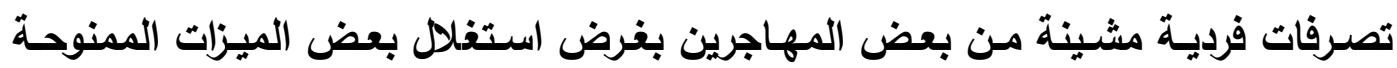

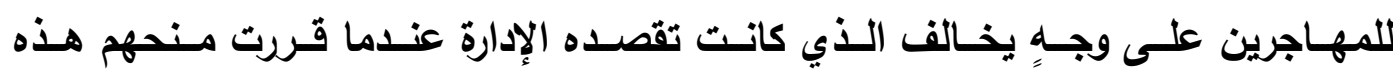
التسهيلات والميزات ولكن لا يمكن التسليم بأن هذه التصرفات كانت سلوكاً عامـاً لجميع

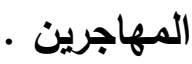
- أمكن رصد اتجاهين أحدهما إيجابي والآخر سلبي غلبا على موقف الثعب المصري عامـة

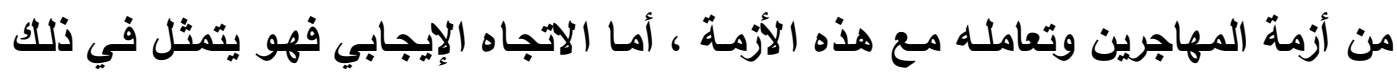

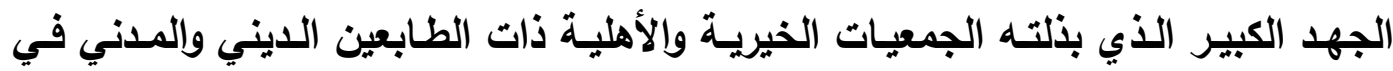

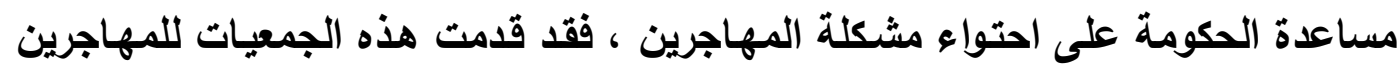

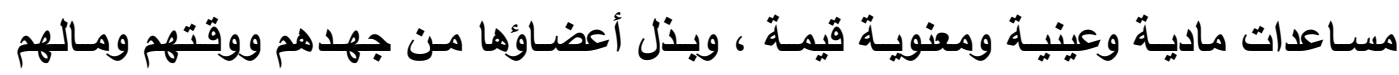

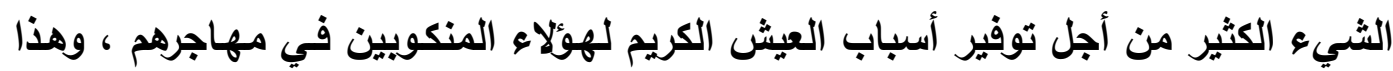

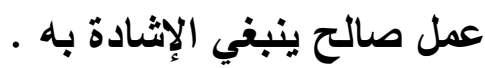
أمـا الاتجـاه المنـاقض وهو الاتجـاه السلبي فقد رأينـاه ممثثلاً في قلـة مـن معدومي

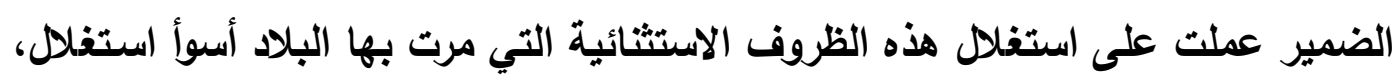

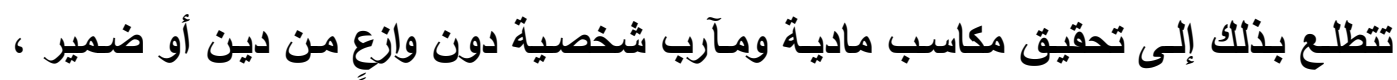

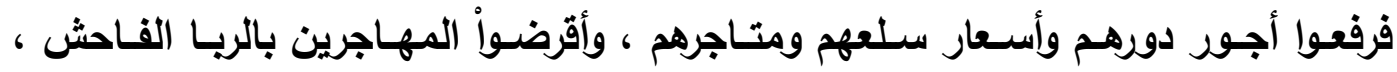

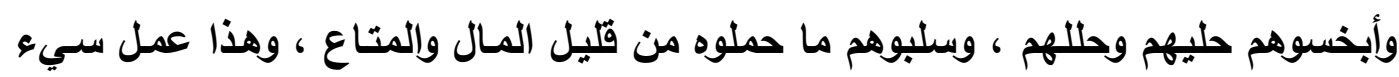




$$
\text { ينبغي التحذير منه . }
$$

- - مثلت هجرة الأهالي المفاجئة على هذا النحو أكبر ظاهرة لتشرد السكان تثهرها مصر في عصورها الحديثة ، وقد حفلت هذه الظاهرة بصورٍ شتى تجسد فاجعة هؤلاء المهاجرين

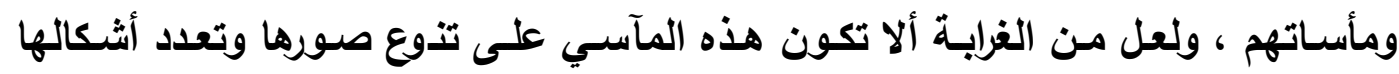

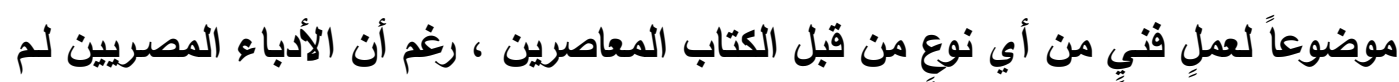

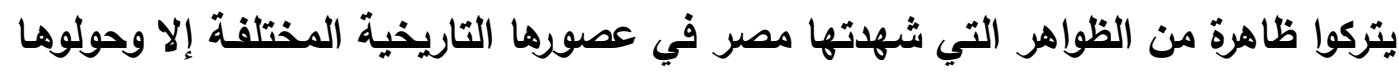

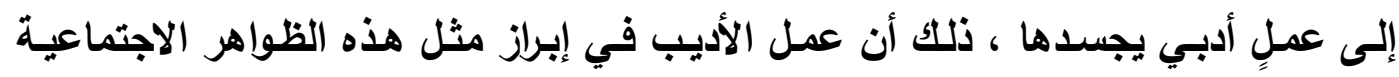

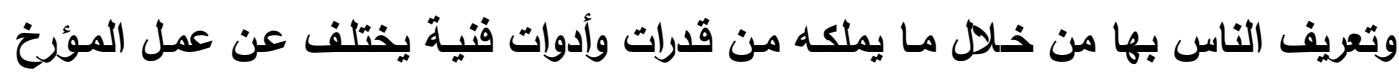

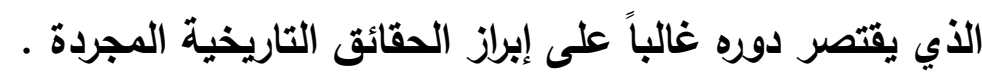

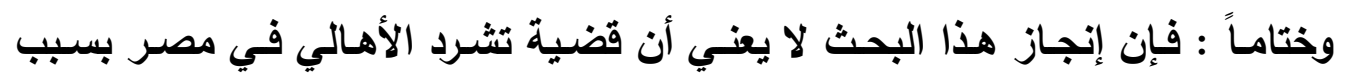

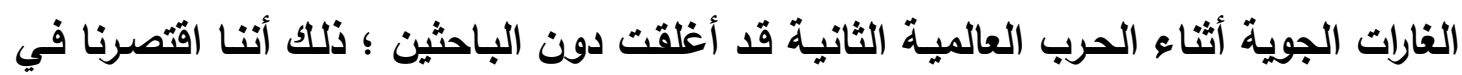
دراستتا هذه على معالجة مسألة التشرد فقط في حد ذاتها دون التطرق إلى القضايا الأخرى

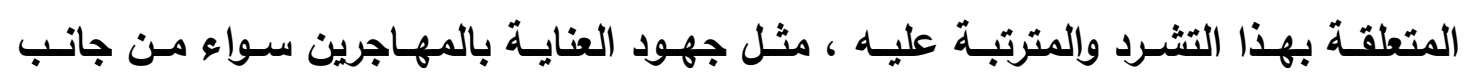

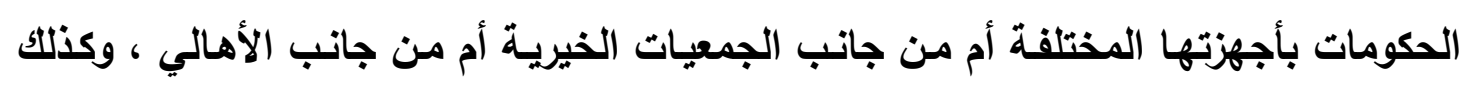

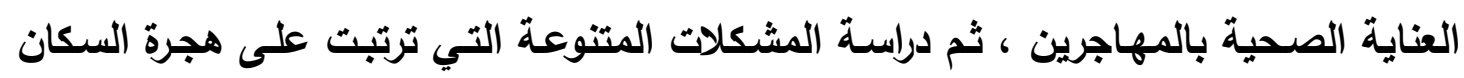
كالاستغلال بكافة أنواعه وأثثاله ، ومثكلة إيجارات مساكن المهاجرين الأصلية التي تركوها

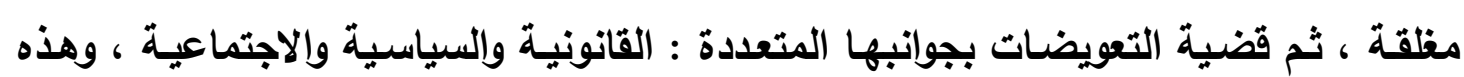

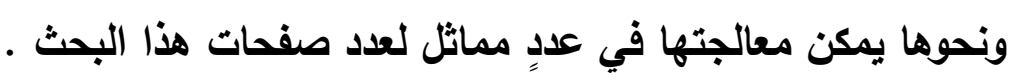
رب سدد الخطى وبارك المسعى 


\section{المسادر والمراجع}

أولاً : الوثائق غير المنشورة والمحفوظة بدار الوثائق القومية بالقاهرة .

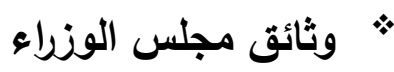

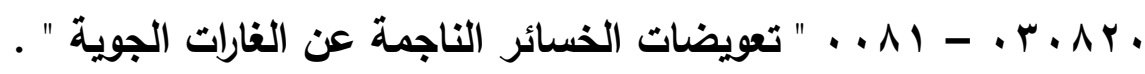

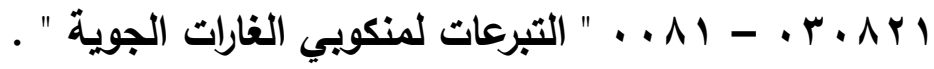

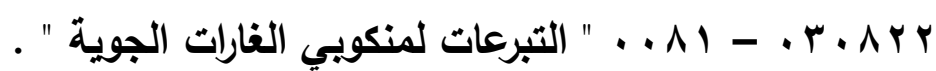

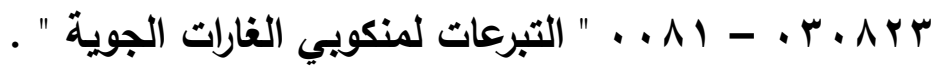

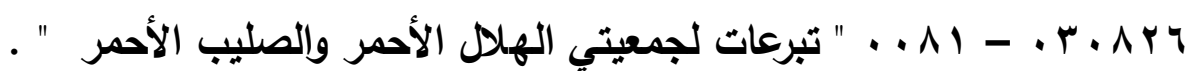

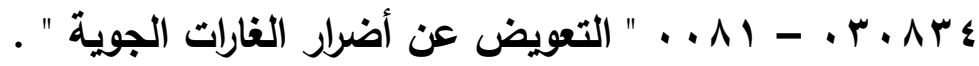

ثانياً : الوثائق المنشورة :

أ) مضابط المجالس النيابية .

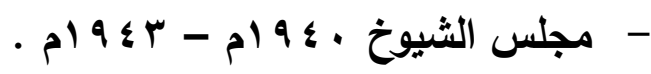

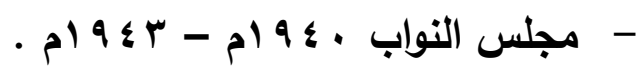

ب) مجلس الوزراء ، الأمانة العامة ، مكتب الأمين : " تاريخ وأعمال الوزارات المصرية

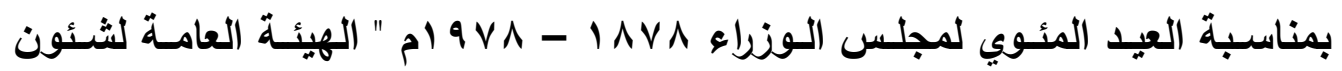

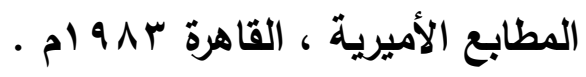

ثالثاً : المصادر والمراجع العربيةقوالمعربة :

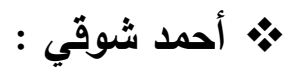

- " الثوقيات " الجزء الأول " التاريخ والسياسة والاجتماع " مطبعة مصر ، بدون تاريخ .

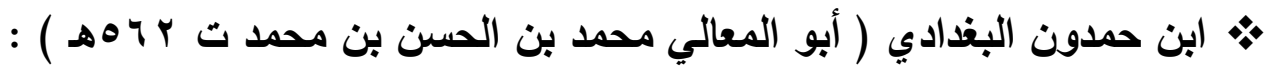

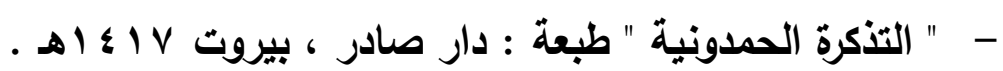

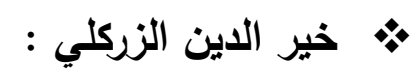

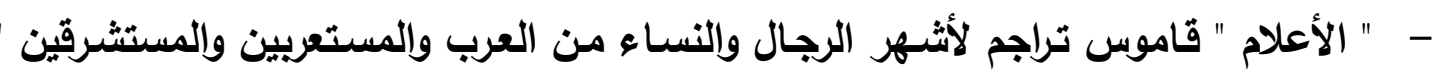

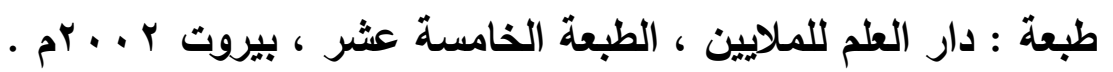

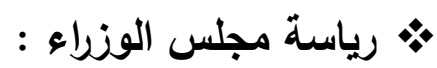

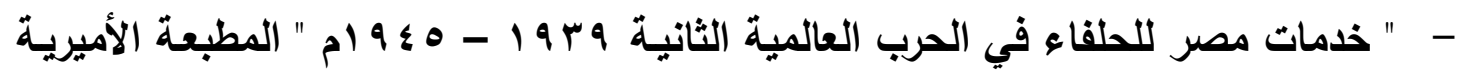

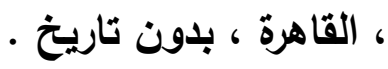

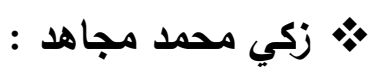

- " الأعلام الثرقية في المائة الرابعة عشرة الهجرية " طبعة : دار الغرب الإسلامي ، الطبعة 


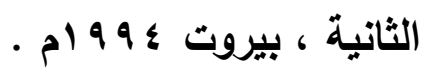

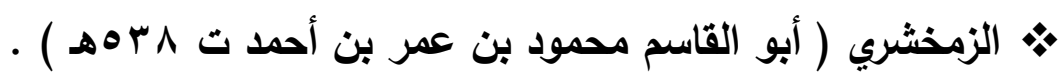

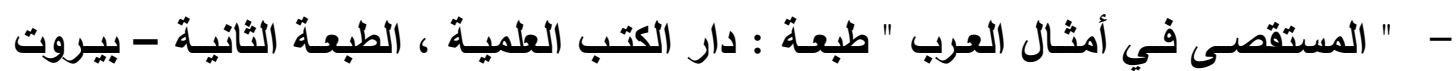
. م) $91 \mathrm{~V}$

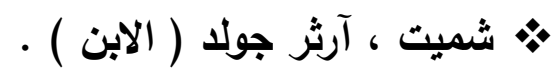

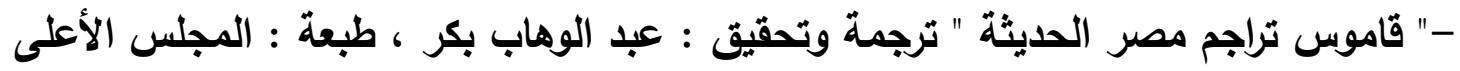

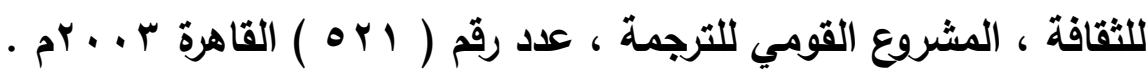

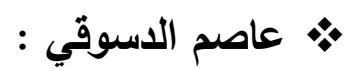

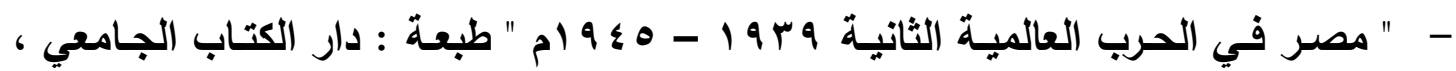

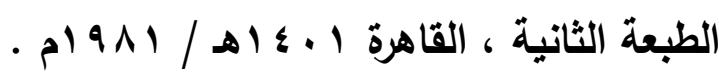

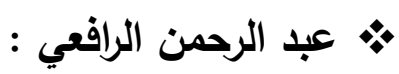

- " الثورة العرابيـة والاحتلال البريطاني " طبعـة : دار المعـارف ، الطبعة الثالثة ، القـاهرة - م) 979

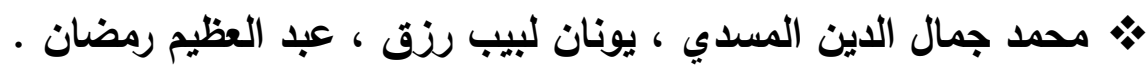

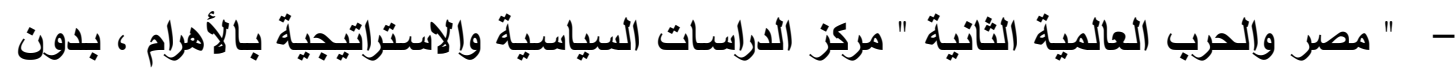
ت تاريخ

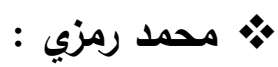
- " القاموس الجغرافي للبلاد المصرية في عهد قدماء المصريين إلى سنة هـ هـ 9 ام " طبعة

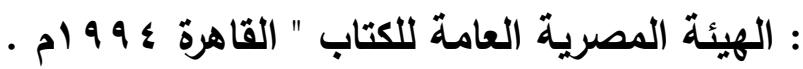

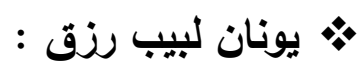

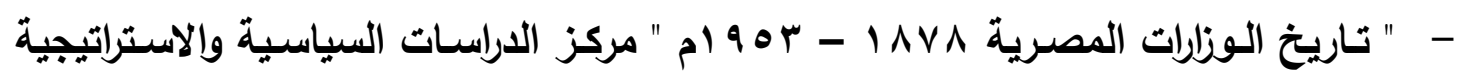

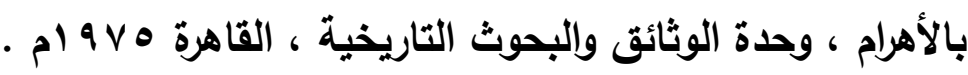

$$
\begin{aligned}
& \text { رابعاً : الاوريات : } \\
& \text { - الأهرام : } \\
& \text { - } \\
& \text { - الدفاع السكندري - } \\
& \text { - } \\
& \text { - الوقائع المصرية . }
\end{aligned}
$$

خامساً : الثبكة الدولية للمطلومات :

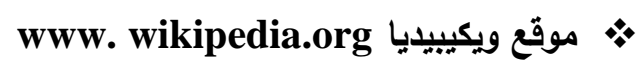




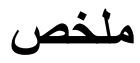

كانت بعض المدن المصرية أثناء الحرب العالمية الثانية هدفاً لغارات طائرات دول المحور بسبب الموقف الودي الذي وقفته مصر إزاء الحليفة بريطانيا تنفيذاً لاثتراطات معاهدة 4 9 ام وذلك على الرغم من وقوف مصر على الحياد من الناحية الرسمية .

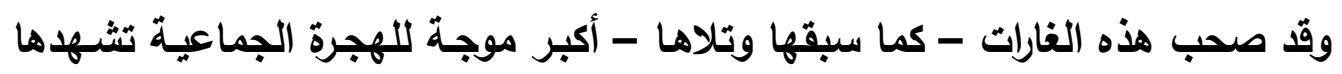

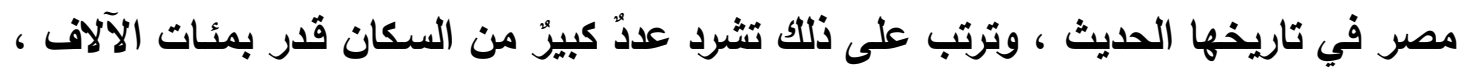

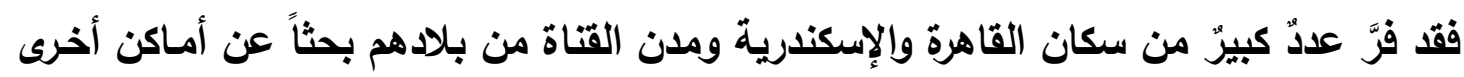

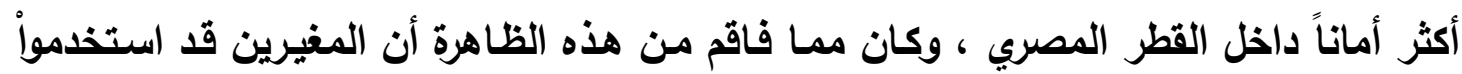

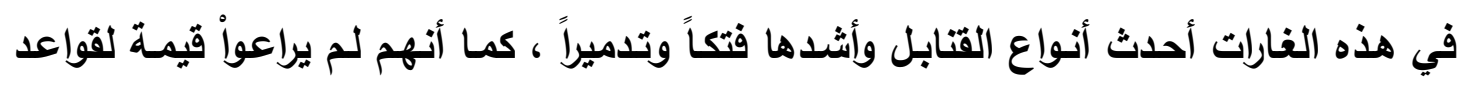

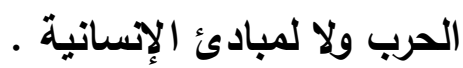
وقد خلفت هذه الغارات العنيفة التي شنتها طائرات دول المحور على المدن المصرية

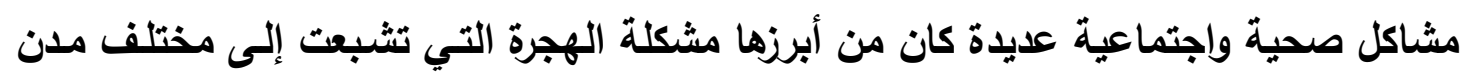
القطر المصري وقراه ، ورغم الجهود التي بذلتها الحكومـة لاحتواء هذه المشكلة إلا أن تزايد

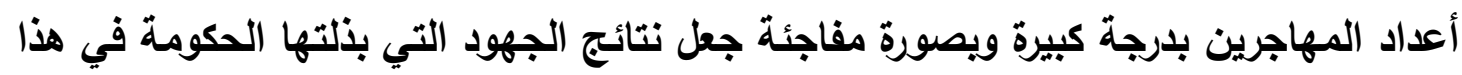

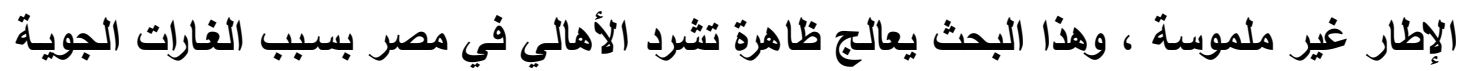

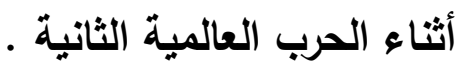




\section{Abstract}

Egyptian cities in World War II were the target of raids aircraft Axis powers. Because of the Egyptian position was next to Britain according to the treaty of 1936. At the same time, the official position of the Egyptian government on the fence and not to stand next to any force from the warring powers.

These raids resulted in the largest wave of immigration waves known to Egypt throughout history. This immigration has led to the displacement of hundreds of thousands of Egyptian families. Cairo, Alexandria, Suez Canal cities residents fled to the country safer. The air raids on Egyptian territory included the latest bombs without censorship of any principle of humanitarian principles.

During these raids increased occurrence of many other health problems, as well as social problems. The most important of these problems is the migrations from conflict areas to safe areas problem.

This paper discusses the displacement of citizens because of air raids in World War II . 